UNIVERSIDADE DE BRASILIA

INSTITUTO DE ARTES

DEPARTAMENTO DE MÚSICA

\title{
A MÚSICA NO "ESPAÇO DA AULA" DO PORTAL DO PROFESSOR DE 2008-2014: AS AULAS PARA O ENSINO MÉDIO
}

MARÍA DÉBORA ORTIZ RODRIGUEZ

BRASÍLIA, 2014 


\section{MARÍA DÉBORA ORTIZ RODRIGUEZ}

\section{A MÚSICA NO "ESPAÇO DA AULA" DO PORTAL DO PROFESSOR DE 2008-2014: AS AULAS PARA O ENSINO MÉDIO}

Dissertação apresentada ao Programa de Pós-graduação "Música em Contexto" do Departamento de Música da Universidade de Brasília, como requisito parcial para obtenção do grau de Mestre em Música.

Área de concentração: Concepções e Vivências no ensino e aprendizagem da música

Orientação: Prof ${ }^{a}$ Dra. Maria Cristina de Carvalho Cascelli de Azevedo 
Ficha catalográfica elaborada automaticamente, com os dados fornecidos pelo(a) autor(a)

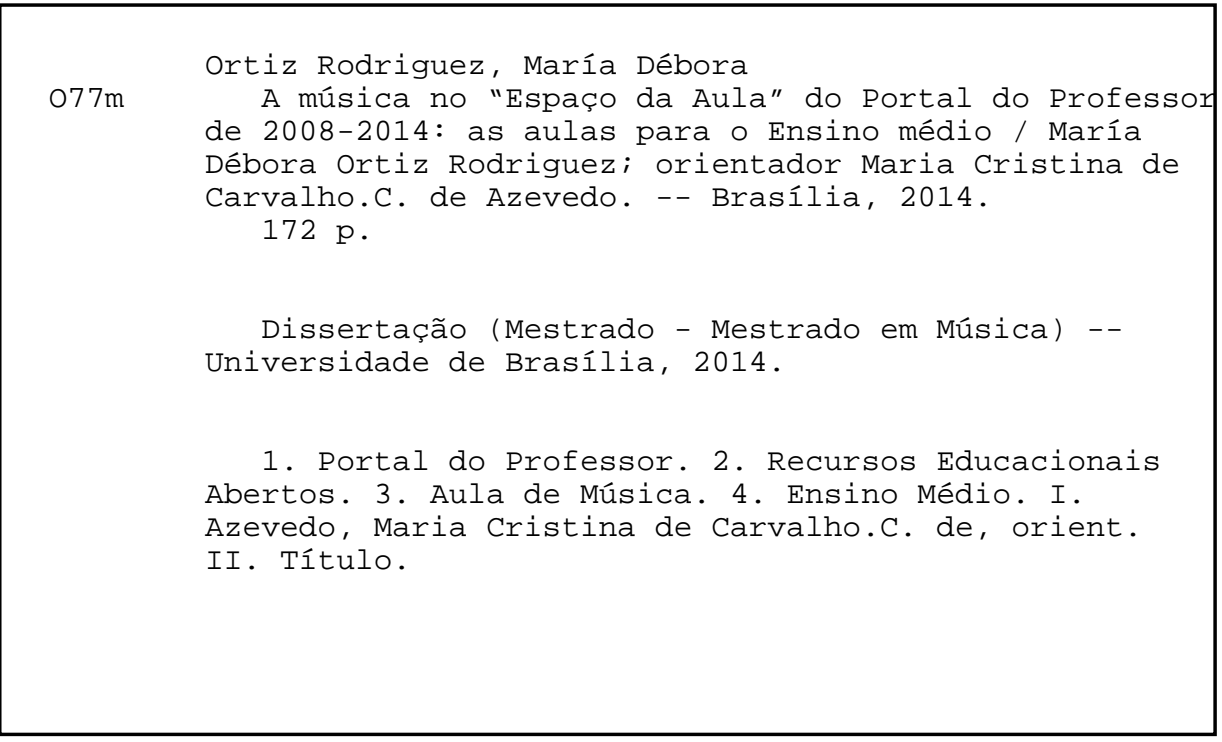




\title{
MARÍA DÉBORA ORTIZ RODRIGUEZ
}

\section{A MÚSICA NO "ESPAÇO DA AULA" DO PORTAL DO PROFESSOR DE 2008-2014: AS AULAS PARA O ENSINO MÉDIO}

\begin{abstract}
Dissertação apresentada ao Programa de Pós-graduação "Música em Contexto" do Departamento de Música da Universidade de Brasília, como requisito parcial para obtenção do grau de Mestre em Música.

Área de concentração: Concepções e Vivências no ensino e aprendizagem da música

Orientação: Prof ${ }^{\mathrm{a}}$ Dra. Maria Cristina de Carvalho Cascelli de Azevedo
\end{abstract}

\section{Banca Examinadora}

Maria Cristina de Carvalho Cascelli de Azevedo (Orientadora) Universidade de Brasília - UnB

Nara Maria Pimentel (Membro Externo)

Universidade de Brasília - UnB.

Wilsa Maria Ramos (Membro Externo)

Universidade de Brasília - UnB.

Paulo Roberto Afonso Marins (Suplente)

Universidade de Brasília - UnB 


\section{AGRADECIMENTOS}

Eu sou muito grata a muitas pessoas de quem tenho recebido, à sua maneira, o seu valioso e gentil apoio.

Agradeço à minha orientadora Prof ${ }^{a}$ Dra. Maria Cristina de Carvalho Cascelli de Azevedo, por ter acreditado em mim, por me proporcionar muitas oportunidades de aprendizado, pela sua paciência e tolerância.

Aos Professores Dra. Nara Maria Pimentel; Dra. Wilsa Maria Ramos; Dr. Paulo Roberto Affonso Marins, por terem aceitado gentilmente fazer parte da minha banca examinadora.

Aos professores do PPGMUS-UnB: Prof. Dr. Antenor Ferreira Corrêa, Prof ${ }^{a}$ Dra. Beatriz Magalhães-Castro, Prof. Dr. Hugo Leonardo Ribeiro, Prof ${ }^{a}$ Dra. Maria Isabel Montandon, Prof. Dr. Paulo Affonso Marins por partilharem os seus conhecimentos.

Minha gratidão à equipe de funcionários administrativos, especialmente Ana Claudia, Deusdete, Paula e Luzia, por estarem sempre prontos a me apoiar e auxiliar.

Às Professoras Dra. Maria Westvall (Suécia), pelos seus conselhos e sugestões e Dra. María Cecilia Jorquera (Chile/Espanha) por compartilharem suas pesquisas e conhecimento.

A todos os meus colegas de curso: Andréa, Augusto, Bigonha, Hermes, Lisette, Mara, Raíssa, Robson, Verônica. A minha turma: Caio, Daniel, Duly Gabriel, Gruwer, Iara, Jaíne, Luis Carlos (Carrapa), Marise, Marcos e Rosa, pelas trocas e amizade; e especialmente aos amigos Heverson pelo seu suporte profissional contínuo, Larissa por partilhar a sua biblioteca, Josilaine por partilharmos logros e dificuldades, Guilherme e Tais pelo seu apoio e linda amizade.

Agradeço o apoio e amizade a todos os meus amigos, especialmente aos queridos amigos de Sampa: Vado (in memoriam), Leo, Isabel, Maria e Albertinho, Sueli, Família Mori; de Brasília: Erica e Jorginho; da Colômbia, pelo seu carinho e compreensão, em especial: Ainda, Nina, Oti e Laura (in memoriam). A Salma, Viví e Adriana que me encaminharam nos primeiros passos.

Minha gratidão especial às amigas Mirinha e Larissa Hermano, por ter feito a minha estada em Brasília mais tranquila e aconchegante.

Meus agradecimentos a minha família toda pelo seu amor, seu incentivo, pelo seu incondicional e continuo apoio. Especialmente agradeço aos meus sobrinhos Alejandro, Dianita, Julis, Sergio e Maria Clara pelo suporte profissional para me tirar de apuros. 
Agradeço ao Departamento de Música, PPGMUS-UnB por ter me permitido a oportunidade de ser parte da sua comunidade discente.

A Universidade de Brasília.

A REUNI-CAPES pela bolsa concedida. 
Quero contar para vocês a estória que mais tenho contado - não aconteceu nunca, acontece sempre. ... "Se é bom ou se é mau, só o futuro dirá."

Rubem Alves (2008, p. 82) 


\section{RESUMO}

Os avanços tecnológicos na área da informação e das comunicações têm ampliado o acesso aos dados, informações, novos conhecimentos e têm promovido a interação entre os indivíduos e os novos modelos e maneiras de ensino e de aprendizagem. Entre as inovações na área educacional, se destacam os Recursos Educacionais Abertos (REA). O Portal do Professor como um tipo de REA disponibiliza aulas de música. Nesse cenário, esta pesquisa objetivou descrever e analisar as aulas de música disponibilizadas no "Espaço da Aula" do Portal do Professor do MEC, identificando: autoria e coautoria; como são planejadas essas aulas, quais os conteúdos, objetivos, atividades, recursos e avaliações disponibilizados. A metodologia de pesquisa adota uma abordagem quali-quantitativa a partir de um estudo de Análise Documental, para descrever, analisar e interpretar as aulas do Portal, a fim de responder às questões de pesquisa. Entre os resultados obtidos, destaca-se a pouca utilização das sugestões de aulas do Portal pelos professores no planejamento de suas atividades musicais. Nas aulas de música analisadas, o uso de Novas Tecnologias da Informação e da Comunicação (NTICs) apresenta-se como uma ferramenta de apoio para atividades e ainda é pouco explorado como recurso músico pedagógico. Os autores das sugestões de aulas de música disponibilizadas no Portal demonstram uma preocupação com atividades e conteúdos que incluam produção musical e contextualização social das práticas musicais. As aulas analisadas revelam as concepções dos autores e coautores sobre a aula de música na Educação Musical Escolar e indicam a importância de se reconhecer o professor como produtor e disseminador de conhecimento pedagógico musical.

Palavras-chave: Portal do Professor, Recursos Educacionais Abertos, Aula de Música, Ensino Médio. 


\section{RESUMEN}

Los avances tecnológicos en el ámbito de la información y de las comunicaciones han aumentado el acceso a los datos, a informaciones, a nuevos conocimientos y han fomentado la interacción entre los individuos y los nuevos modelos y formas de enseñanza y aprendizaje. Entre las innovaciones en materia educativa sobresalen los Recursos Educativos Abiertos (REA), siendo el Portal del Profesor uno de estos espacios en el que se disponen clases de música. En este panorama, la presente investigación tiene como objetivo analizar y describir las clases de música en el "Espacio de la Clase" del "Portal do Profesor" del Ministerio de Educación (MEC), identificando la autoría y coautoría; como son planeadas: cuáles contenidos, objetivos, actividades, recursos y evaluación se utilizan. La metodología de investigación adopta un enfoque cuali-cuantativo de análisis documental, para describir, analizar e interpretar los documentos con el fin de responder a las cuestiones de investigación. Esta investigación demuestra que el Portal e poco usado por los profesores para la producción de clases de música. En las clases de música analizadas, el uso de las Nuevas Tecnologías de la Información y de la Comunicación (NTICs) se presenta como una herramienta de apoyo para las actividades y aún es poco explotado como un recurso músico pedagógico. Los autores de las clases de música disponibles en el Portal demuestran una preocupación por actividades y contenidos que incluyan la producción musical y el contexto social de las prácticas musicales. Las clases de música revelan las concepciones de los autores y coautores sobre la Educación Musical Escolar y la importancia de reconocer al profesor como productor y difusor de conocimiento pedagógico musical.

Palabras clave: Portal do Professor, Recursos Educativos Abiertos, Clase de Música, Educación Média. 


\begin{abstract}
Technological advances in communication and information have expanded access to data and knowledge, creating new ways to convey information, and have promoted interaction between individuals and the new models of teaching and learning. Open Educational Resources (OER or REA abbreviation in Portuguese) are an innovation in education, and the Portal do Professor (Teacher's Portal) in Brazil is one of them, where music lessons are available. This research aims to describe and analyze music lessons available in the "Espaço da Aula" (Lesson Place) at the Portal do Professor from the Brazilian Ministério da Educação (MEC) (Brazilian Ministry of Education), as well as to identify authorship and co-authorship; how lessons are planned: which content, objectives, activities, assessment and resources are used. The methodology used is a quali-quantitative research and document analysis, to describe, analyze and interpret documents, in order to answer research questions. This research shows that the music lessons of the Portal are little used by teachers in their teaching classes and music activities. The use of New Information Technologies and Communication (ICTs) within classes is presented as a tool to support activities and is still poorly exploited as an educational resource musical. The authors of the music classes available in the Portal demonstrate a concern for activities and contents that include music production and the social context of musical practices. Music lessons show the conceptions of the authors and coauthors of music class in School Music Education and the importance of recognizing the teacher as producer and promoter of musical pedagogical knowledge.
\end{abstract}

Key words: "Portal do Professor", Open Educational Resources (OER), music class, school education (Secondary Education). 


\section{LISTA DE FIGURAS E GRÁFICOS}

Figura 1 - Gráfico: percentual de professores usuários de recursos da internet. .............................................23

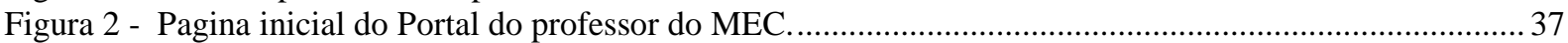

Figura 3 - Atual da página inicial do Portal do professor do MEC ........................................................... 37

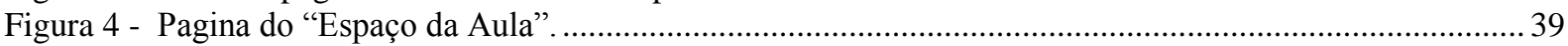

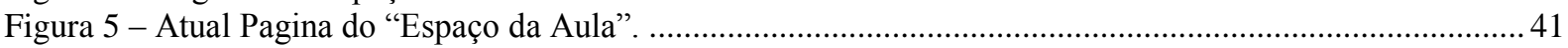

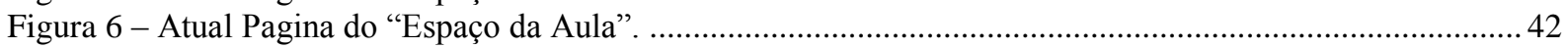

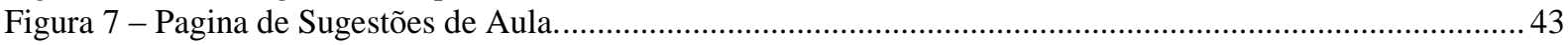

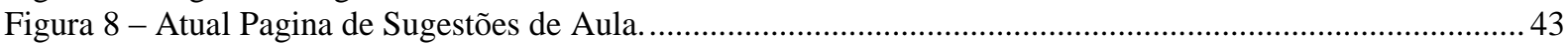

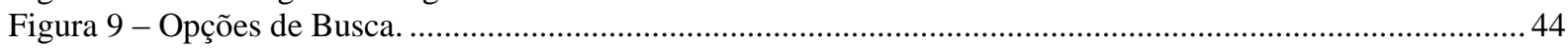

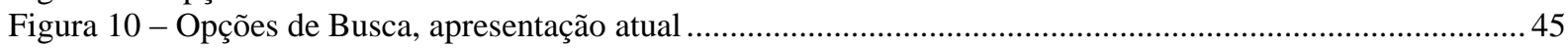

Figura 11 - Espiral de desenvolvimento musical de Swanwick e Tillman. .................................................. 72

Gráfico 1 - Categoria objetivos, frequência de uso................................................................................... 104

Gráfico 2 - Categoria Recursos, frequência de uso............................................................................ 118 


\section{LISTA DE QUADROS E TABELAS}

Quadro 1 - Sistema de Educação Básica ................................................................................................. 46

Quadro 2 - Organização da Educação Básica segundo Portal do Professor - MEC ........................................ 46

Quadro 3 - Temas da disciplina Música por Nível de Ensino segundo organização do Portal .......................... 47

Quadro 5 - Componente Curricular Temas da disciplina Música por Modalidade de Ensino ............................48

Quadro 6 - Classificação de "modelos didáticos” segundo García Pérez (2000) ............................................67

Quadro 7 - Classificação de "modelos didáticos”" segundo Jorquera (2010) ...................................................6. 68

Quadro 8 - Amostragem das aulas repetidas na seleção intencional de aulas do Ensino Médio por tema e ordem

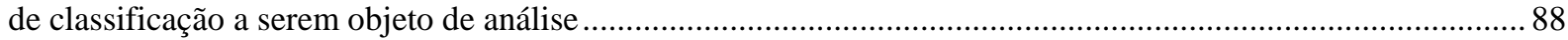

Quadro 9 - Organização da amostra de aulas por $\mathrm{N}^{\circ}$ sequencial de seleção , Autor e Título. ...........................91

Quadro 10 - Aulas amostra intencional aleatória por sorteio ...................................................................93

Quadro 11 - Parâmetros de análise - planilha de elementos de disponibilização de aula (Apêndice C)............. 94

Quadro 12 - Parâmetros de análise - categorias (Apêndice D) ...............................................................94

Quadro 13 - Quantidade de aulas por autor (AT), Estado e data de publicação - N=48 aulas ...........................97

Quadro 13 - Quantidade de aulas por autor (AT), Estado e data de publicação - N=48 aulas .........................98

Quadro 14 - Quantidade de aulas com coautoria por autor .................................................................98

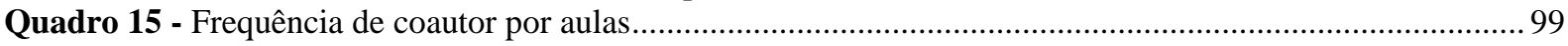

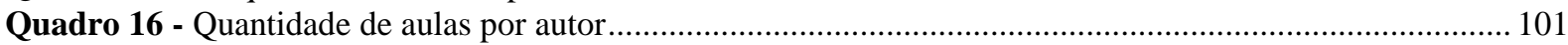

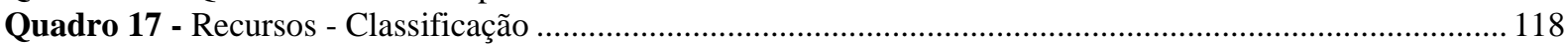

Tabela 1 - Acessos ao Portal desde o seu lançamento em 16 de junho de 2008 até Setembro de 2013 .............. 35

Tabela 2 - Quantidade de aulas de música por período de busca ................................................................. 84

Tabela 3 - "Tipo de Pesquisa” e Número de Aulas de Música ...................................................................... 85

Tabela 4 - Quantidade de aulas de música por períodos de busca ..............................................................86

Tabela 5 - Quantidade de aulas de música por Nível /Modalidade e Tema do Componente curricular Arte ........87 


\section{LISTA DE ABREVIATURAS E SIGLAS}

AVA - Ambiente Virtual de Aprendizagem

CMSI - Cúpula Mundial da Sociedade da Informação

BDTD - Biblioteca Digital Brasileira de Teses e Dissertações

BIOE - Banco Internacional de Objetos Educativos

CAPES - Coordenação de Aperfeiçoamento de Pessoal de Nível Superior

CNPq - Conselho Nacional de Desenvolvimento Científico e Tecnológico

EaD - Educação a Distância

IBCT - Instituto Brasileiro de Informação em Ciência e Tecnologia

LDB - Lei de Diretrizes Curriculares Nacionais Da Educação Básica

MEC - Ministério da Educação

NTICs - Novas tecnologias de informação e das comunicações

OCNEM - Orientações Curriculares para o Ensino Médio

OER - Open Education Resources

OVA - Objeto Virtual de Aprendizagem

PCN - Parâmetros Curriculares Nacionais

PCN+ Ensino Médio - Orientações Educacionais Complementares aos Parâmetros Curriculares Nacionais 
PEA-UNESCO - Programa das Escolas Associadas

REA - Recursos Educacionais Abertos

RELPE - Rede Latino-americana de Portais Educativos

NTICs - Novas Tecnologias da informação e das comunicações

UNESCO - Organização das Nações Unidas para a Educação, a Ciência e a Cultura 


\section{SUMÁRIO}

1 INTRODUÇÃO ........................................................................................................17

2 O ESPAÇO VIRTUAL: RECURSOS E PORTAIS EDUCACIONAIS ...........................26

2.1 RECURSOS EDUCACIONAIS ABERTOS - REA …………………………………....28

2.2 PORTAL DO PROFESSOR ………………………….......................................... 33

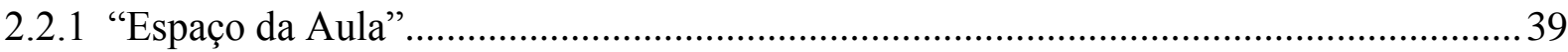

2.2.2 As Pesquisas na temática Portal do Professor, Espaço da Aula, Música e Aula de Música

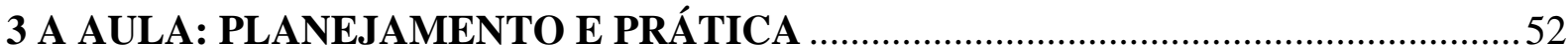

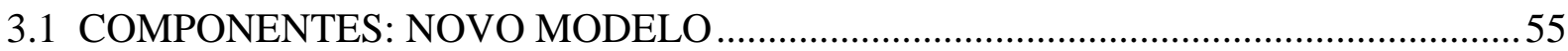

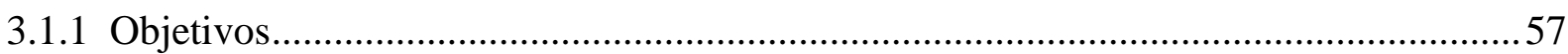

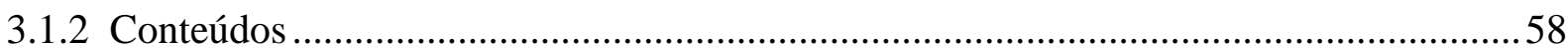

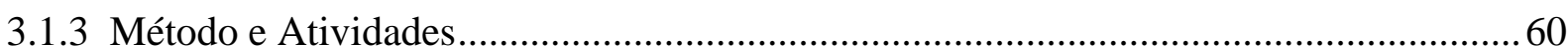

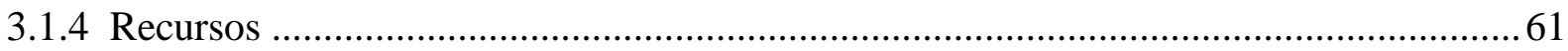

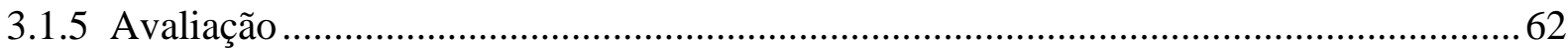

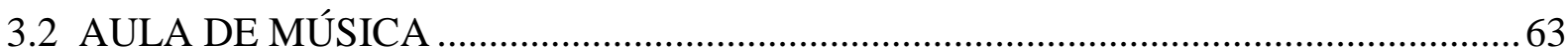

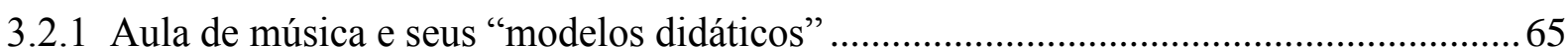

4 PROCEDIMENTOS METODOLÓGICOS: O CORPUS DOCUMENTAL E SUA INTERPRETAÇÃ

4.1 A PESQUISA QUALI-QUANTITATIVA: APROXIMAÇÕES E

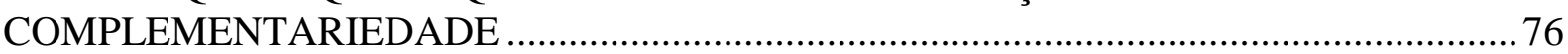

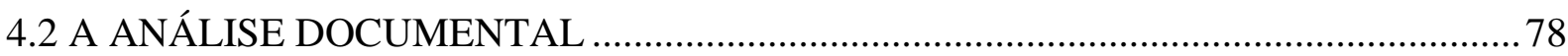

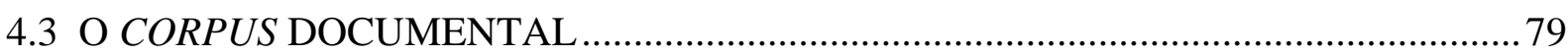

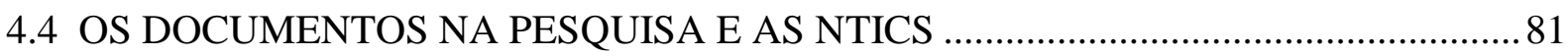

4.5 BUSCA E SELEÇÃO DAS PROPOSTAS DE AULAS DE MÚSICA DO PORTAL ....83

4.5.1 Navegação, busca e levantamento de aulas no portal................................................... 83

4.5.2 Segunda busca avançada e primeira seleção de aulas ................................................. 86

4.5.3 Seleção de aulas por meio de amostragem aleatória .................................................... 89

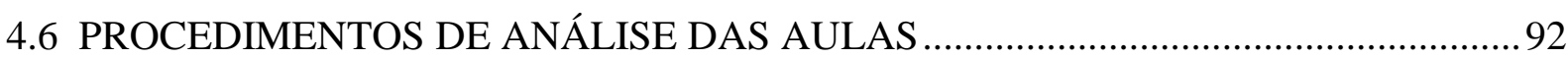

4.6.1 Organização das aulas em tabelas e gráficos e análise de amostra intencional..............92

4.6.2 Categorização das aulas do Portal .................................................................................93

4.6.3 Interpretações quantitativa e qualitativa dos dados ..................................................96

5 AS AULAS DE MÚSICA NO "ESPAÇO DA AULA": INTERPRETAÇÃO E

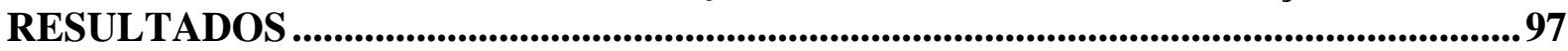

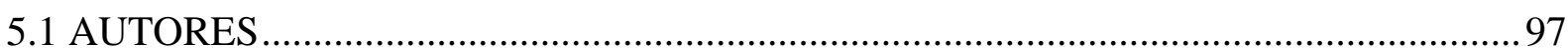




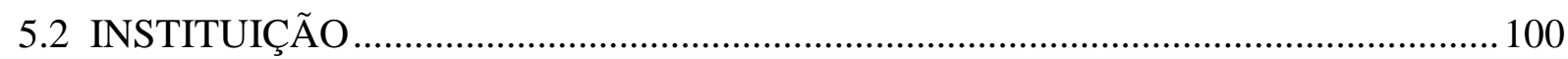

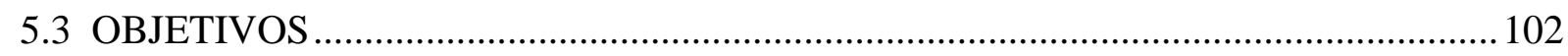

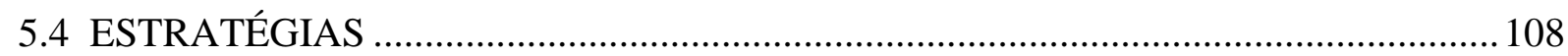

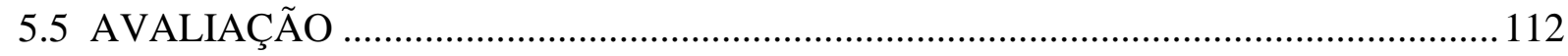

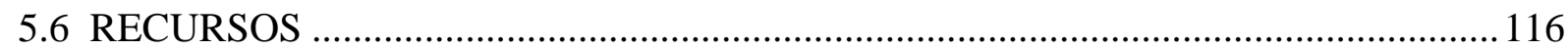

5.7 AS AULAS DE MÚSICA PRINCÍPIOS E CONCEPÇÕES........................................... 120

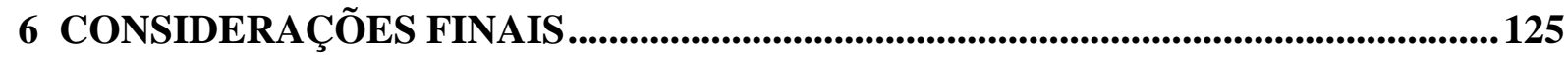

REFERÊNCIAS BIBLIOGRÁFICAS ..................................................................................131

APÊNDICE A - PRIMEIRA SELEÇÃO DE AULAS DE MÚSICA DO PORTAL DO PROFESSOR. SELEÇÃO INTENCIONAL DAS 10 PRIMEIRAS AULAS DE CADA

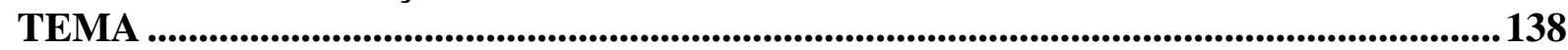

APÊNDICE B - PROCESSO DE AMOSTRAGEM: ORGANIZAÇÃO DAS AULAS DA AMOSTRAGEM ALEATÓRIA ..................................................................................142

APÊNDICE C - PLANILHA PB1 .......................................................................145

APÊNDICE D - PLANILHA PB2 CATEGORIAS. AMOSTRA DE ANÁLISE ATÉ

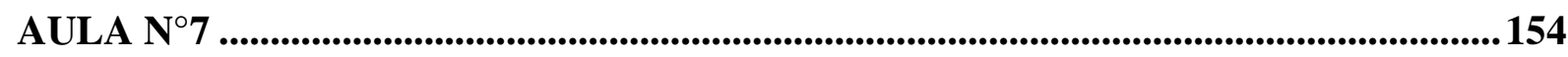

ANEXO A - CLASSIFICAÇÃO DE “MODELOS DIDÁTICOS” ELABORADO POR GARCÍA PÉREZ (2000 P. 28)...........................................................................................159

ANEXO B - CLASSIFICAÇÃO DE "MODELOS DIDÁTICOS" ELABORADO POR MARÍA CECILIA JORQUERA (2010 PP. 68-70)..............................................................160

ANEXO C - AULA No 3 "MÚSICA - PERCUSSÃO CORPORAL: MÃOS”................162

ANEXO D - AULA Nº, "UMA ORQUESTRA DIFERENTE"........................................165

ANEXO E - AULA No 19, "MÚSICA - CRIAÇÃO DE CANÇÃO: RITMO E GÊNERO” 168 


\section{INTRODUÇÃO}

A Cúpula Mundial sobre a Sociedade da Informação (CMSI) ${ }^{1}$ afirma que as Novas Tecnologias da Informação e das Comunicações (NTICs) ao promoverem a revolução digital têm influenciado na maneira como as pessoas pensam, atuam, se comunicam, trabalham e garantem o seu sustento. Surgem daí, novas formas de transmitir informação, de produzir, de socializar conhecimento e de educar. Segundo a UNESCO, são mudanças sociais induzidas pelas novas tecnologias conforme destaca o texto abaixo:

A natureza interativa das redes digitais confere aos usuários das tecnologias uma situação que anteriormente não tinham. Eles não podem ser passivos perante a informação, porque constantemente estão sempre a selecioná-la e classificá-la. Atualmente, as tecnologias de comunicação não precedem à elaboração e construção dos conhecimentos, mas interagem com eles (UNESCO, 2005, pp.55-56) [tradução nossa] $]^{2}$.

Nesse ambiente, os professores têm sido desafiados a pensar e a repensar suas práticas e sua formação, no sentido de criar e desenvolver novas situações pedagógicas que possibilitem a interação de seus alunos com o conhecimento disponível nas redes digitais. Conhecer esses recursos e aprender a utilizá-los em sala de aula tem sido também um dos desafios da minha própria experiência docente. Assim, tenho me preocupado com novas estratégias e recursos educativos em que as NTICs não sejam apenas um elemento ilustrativo, mas um elemento inovador e interativo nas atividades planejadas e propostas.

$\mathrm{Na}$ minha vivência como educadora, na educação musical, trabalhei com todas as faixas etárias, especialmente com crianças e, nos últimos anos, o veloz avanço das NTICs e suas possibilidades de interação e ampliação da informação tem me suscitado novas demandas e estratégias de ensino e aprendizagem de música. Dentre as inovações digitais, se destacam a relativa facilidade para: encontrar músicas outrora dificilmente acessíveis; novos formatos de áudio como os populares MP3, OGG, MPEG-4, WMA; acessar efeitos sonoros; registrar experiências musicais; adquirir novos dispositivos com recursos de gravação e reprodução como CDs, microcomputadores, telefone celular; e acessar programas (softwares) musicais para ensino e aprendizagem musical, treinamento auditivo, reprodução, gravação e

\footnotetext{
${ }^{1}$ A Cúpula Mundial sobre a Sociedade da Informação (CMSI, 2003, 2005) desenvolveu-se em duas fases. A primeira fase em Genebra patrocinada pelo Governo de Suíça, entre 10 e 12 de dezembro de 2003 e a segunda em Tunes patrocinada pelo Governo de Tunes, de 16 a 18 de novembro de 2005.

${ }^{2}$ El carácter interactivo de las redes digitales confiere a los usuarios de las tecnologías una situación que no tenían anteriormente. Ya no pueden ser pasivos ante la información porque la están seleccionando y jerarquizando continuamente. En la actualidad, las tecnologías de la comunicación no preceden a la elaboración y construcción de los conocimientos, sino que interactúan con éstos. (UNESCO, 2005, pp.55-56)
} 
edição. Essas possibilidades de interação com a música foram, gradativamente, fazendo parte dos materiais e recursos utilizados por mim e pelos meus estudantes nas aulas de música, para explorar, apreciar e registrar trabalhos e experiências de criação musical.

$\mathrm{Na}$ minha história pessoal, destaco três contextos distintos em que fui desafiada a lidar com as NTICs e a cultura escolar: na escola de ensino básico onde aos poucos os novos recursos e informação digitalizada são incorporados; na docência em escola especializada de música, aonde os estudantes chegam diariamente com novos dispositivos, programas computacionais de edição, gravação e emissão de música e na experiência Homeschooling ${ }^{3}$ (LYMAN, 2000), com grupos de crianças, entre os cinco (5) e onze (11) anos de idade, que me "obrigavam" a pensar "o que" e "como" ensinar no mundo das NTICs. Essas crianças manipulavam, com bastante habilidade, sistemas de videoconferência, estudavam em plataformas virtuais de aprendizagem e dominavam programas e dispositivos eletrônicos que eu mal começava a conhecer com os meus pares. Elas eram eximias usuárias das NTICs.

Nesse novo contexto educacional eu precisei buscar novas estratégias e ferramentas mais ágeis e acessíveis que facilitassem os processos de ensino e aprendizagem e a aplicação do conhecimento. A necessidade de atualizar meus conhecimentos no mundo digital, e computadorizado, me levou à procura de cursos e atualização profissional. Um desses cursos foi uma especialização em modalidade virtual, onde desenvolvi uma proposta músico-pedagógica ${ }^{4}$ no formato de hipertexto, como Objeto Virtual de Aprendizagem (OVA), uma estratégia educacional para análise, apreciação, arranjo e composição musical.

O projeto foi uma oportunidade de explorar novos recursos e ferramentas digitais realizando uma coletânea, organização e seleção de obras musicais de um compositor brasileiro, pouco conhecido, com o objetivo de aproximar e interagir o público com sua obra. Porém, o projeto apresentou limitações de acessibilidade, de socialização, de trocas de informação, de colaboração e de interação. As composições do músico e os conteúdos musicais estavam disponíveis para acesso dos usuários, mas faltava propiciar situações didáticas que induzissem a familiaridade com as obras do compositor e com o conhecimento musical disponibilizado no ambiente virtual, o objetivo inicial da proposta. Essa reflexão me estimulou a conhecer e analisar os recursos educacionais disponíveis no espaço virtual para fins educacionais para entender como eles resolviam essa situação. Que tipos de recursos

\footnotetext{
${ }^{3}$ Homeschooling é o nome dado ao ensino escolar em casa. Pode-se saber mais a respeito em LYMAN, Isabel. The Homeschooling Revolution. Bench Pr Intl, 2000.

${ }^{4}$ Esta proposta foi criada como projeto final de curso de pós-graduação lato senso em modalidade virtual.
} 
estão sendo disponibilizados? Como eles são organizados em termos de acessibilidade, conteúdo e interação? Que tipos de interação pedagógica propiciam?

Essa indagação me levou ao Portal do Professor do Ministério de Educação (MEC). Esse foi criado em 2007 e é disponibilizado desde 2008, sendo um espaço de troca de saberes, de socialização de experiências, de gestão de sala de aula e de atualização, especialmente, dirigido a professores na educação básica.

O Portal como recurso educacional pode ser acessado em qualquer lugar que tenha internet; permite ser usado por qualquer pessoa; apresenta uma série de possibilidades de uso e o professor pode, entre outras: trocar ideias; se atualizar com novos temas e artigos; informar-se sobre cursos, seminários ou encontros; acessar o repositório do Banco Internacional de Objetos Educacionais (BIOE); acessar diversos recursos digitais para usar nas suas próprias aulas; acessar aulas de outros professores e de diversas disciplinas e socializar suas próprias aulas. Os professores têm a possibilidade de copiar, adaptar e partilhar materiais.

As características descritas acima definem o Portal como Recurso Educacional Aberto ou REA. Entende-se REA como recursos digitais de livre acesso e de licença aberta; criados e atualizados constantemente, com a possibilidade de ser usados, adaptados, partilhados ou combinados.

O termo REA, do inglês Open Education Resources (OER), foi usado pela primeira vez no Fórum da UNESCO de 2002, financiado pela Fundação Hewlett e pela Cooperativa Ocidental de Telecomunicações para a Educação (WCET), cujo tema discutiu o impacto dos cursos abertos no Ensino Superior nos Países em Desenvolvimento. O evento definiu REA como:

Provisão de recursos educacionais com licença aberta, habilitados por informações e tecnologias de comunicação, para consulta, utilização e adaptação por uma comunidade de usuários para fins não comerciais (UNESCO, 2002, p.24) [tradução nossa] ${ }^{5}$.

Os REA apresentam-se de diversas formas como definido na seguinte citação:

Os REA podem incluir cursos completos, partes de cursos, módulos, livros didáticos, artigos de pesquisa, vídeos, testes, softwares, e qualquer outra

\footnotetext{
5 "The open provision of educational resources enabled by information and communication technologies, for consultation, use and adaptation by a community of users for non-commercial purposes" (UNESCO, 2002, P.24).
} 
ferramenta, material ou técnica, que possa apoiar o acesso e a produção de conhecimento. (ROSSINI e GONZALEZ, 2012, p.38).

$\mathrm{Na}$ América Latina, o ensino e a aprendizagem de música e a investigação em educação musical, sob as políticas educacionais emergentes, transitam em Ambientes Virtuais de Aprendizagem (AVA), em Comunidades Virtuais de Aprendizagem, em Repositórios de Objetos Virtuais de Aprendizagem, em Portais educacionais e outros projetos e experiências que podem ser considerados Recursos Educacionais Abertos (REA) e que recebem financiamento e incentivos especiais de instituições públicas e privadas.

Como REA, o Portal do Professor do MEC apresenta uma série de recursos onde o professor pode acessar materiais e dispositivos que auxiliam e complementam a sua própria prática e formação contínua. Um desses recursos é o da produção e socialização de aulas.

No Portal, as aulas de música são criadas e disponibilizadas no "Espaço da Aula", elemento indicado por uma aba à esquerda na margem superior da janela principal do Portal. O elemento "Espaço da Aula" é uma das sete "grandes áreas" apresentadas no Portal do Professor. Nessa "grande área" o Portal disponibiliza orientações pedagógicas e técnicas para o professor produzir, planejar, elaborar, submeter, partilhar, publicar, localizar ou acessar aulas, com a possibilidade de comentá-las, imprimi-las ou guardá-las no seu arquivo pessoal, esse arquivo também é oferecido como recurso no "Espaço da Aula".

As aulas devem ser criadas e direcionadas pelo menos para um dos níveis escolares da Educação Básica: Educação Infantil; Ensino Fundamental Inicial; Ensino Fundamental Final; Ensino Médio ou Educação Profissional ${ }^{6}$. Ou para às diferentes modalidades escolares: Educação de Jovens e Adultos - $1^{\circ}$ ciclo; Educação de Jovens e Adultos - $2^{\circ}$ ciclo ou Educação Escolar Indígena.

Elas são criadas de acordo com orientações e parâmetros que envolvem o uso das Novas Tecnologias da Informação e Comunicação ou NTICs. O termo TIC é descrito como um conjunto diversificado de ferramentas tecnológicas e recursos usados para se comunicar e criar, difundir, armazenar e gerenciar informação (BLURTON, 1999, p. 1), o termo "novo", segundo Manovich (2005, p.64) refere-se à convergência entre as tecnologias midiáticas e da informática, com as características da interatividade e a hipermídia.

Nesse sentido, as aulas podem apresentar, em menor ou maior grau, o uso de recursos multimídia como vídeos, gravações, programas de criação e edição musical. Propiciar a

\footnotetext{
${ }^{6}$ No Portal do Professor, Educação Profissional e Tecnológica é disponibilizada como Nível e não como Modalidade como nos PCN.
} 
familiaridade com esses recursos e o seu uso pedagógico em sala de aula é um dos objetivos do Portal, uma vez que esse tema tem representado um dos grandes desafios para a atuação do professor e o seu trabalho docente. Nesse sentido, esta pesquisa questiona: como são as aulas de música do Portal do Professor? Que recursos utilizam? Quem são os autores e coautores? Como são planejadas (conteúdos, objetivos, atividades, avaliação)?

O objetivo da pesquisa é descrever e analisar as aulas de música disponibilizadas no "Espaço da Aula" do Portal do Professor do MEC, identificando: autoria e coautoria; como são planejadas essas aulas, quais os conteúdos, objetivos; atividades, recursos e avaliações disponibilizados.

No "Espaço da Aula" do Portal, as aulas são guiadas por uma rede de significados que revelam as concepções, valores e crenças que os professores têm do que seja e de como deve ser desenvolvida uma aula de música. De forma semelhante, o uso que os professores fazem das NTICs no seu planejamento revela os seus saberes, concepções e valores com relação aos recursos tecnológicos e digitais e o seu emprego pedagógico em aulas de música. As aulas refletem, portanto, o pensamento e a forma de agir do professor e revelam diferentes modelos e princípios de docência e de aula de música. Esses princípios e modelos estão sendo socializados na rede, o que merece nossa atenção e análise.

Guttman (2003, p.9) define as TICs como forças motrizes para o crescimento e ferramentas para o fortalecimento da autonomia, além de terem profundas implicações na inovação, mudança e melhoria do ensino. Considerando essa afirmação, esta pesquisa enfatiza a importância de se refletir sobre as mudanças e inovações trazidas para a aula de música e de se conhecer os princípios pedagógico-musicais que as estão orientando.

O Portal do Professor, disponibilizado livre e abertamente, condição necessária para se considerar REA, é uma oportunidade para entender e compreender como são as aulas de música ali disponibilizadas, seu conteúdo, seus recursos e os princípios pedagógico-musicais dos seus autores.

No Brasil, as pesquisas com temática sobre o Portal do Professor estão se ampliando, mas ainda são poucas. Essa afirmação é comprovada por levantamento bibliográfico realizado no Banco de Teses (BT) da Capes, abrangendo os anos de 2000 a 2014. Na busca realizada foram utilizadas as palavras-chave "Música" e "Portal do Professor" como expressão exata, quando foram encontradas seis pesquisas de mestrado acadêmico, uma de mestrado profissional e uma de doutorado relacionadas com o Portal, mas nenhuma delas na área de música. Dessas pesquisas, três são dissertações de mestrado acadêmico na área da Educação 
(ano 2011), três em Educação em Ciências e Matemática (anos 2011 e 2012) e uma em Comunicação Social (ano 2011). Esta última é uma dissertação desenvolvida por Habeyche (2011) que investigou weblogs disponibilizados na grande área "Colaboração" do Portal do Professor. As pesquisas em Educação foram desenvolvidas por: Santos (2011), que discute um projeto de trabalho utilizando recursos do Portal do Professor para aprendizagem de conceitos matemáticos; Tinti (2011) que aborda o tema das práticas inclusivas nos planos de aula do Portal do Professor e Gense (2011) que aborda a inclusão digital e o ensino de língua inglesa. As dissertações em Educação em Ciência e Matemática e Educação Matemática e Tecnológica: Freitas (2011) analisou a organização das aulas de Biologia publicadas no Espaço da Aula do Portal; Carmo (2012) sobre o planejamento da aula e a inclusão digital e Lehner (2012) Mestrado profissional, consistindo na elaboração de um tutorial para o uso de Objetos de Aprendizagem com tema genética.

A pesquisa de Doutorado na área da Educação em Ciências Química da Vida e Saúde desenvolvida por SEPEL (2012) propôs uma associação entre atividades práticas e História da Ciência para o ensino de Ciências no Ensino Médio.

No levantamento bibliográfico realizado no repositório do BDTD do Instituto Brasileiro de Informação em Ciência e Tecnologia (IBICT), novamente abrangendo os anos de 2000 a 2014 e utilizando na busca realizada as palavras-chave "Música" e "Portal do Professor" como expressão exata. Foram encontradas, as seguintes Dissertações: Bataliotti (2014) em Educação Especial, sobre a aplicabilidade dos planos de aula de Educação Física do Portal na prática inclusiva e Zacharias (2013), em Linguística Aplicada, identifica propostas de introdução das tecnologias no letramento do Ensino Fundamental. Além da Tese de Doutorado e duas das Dissertações das encontradas no BT da CAPES já relatadas acima

Um aspecto ainda a destacar é a grande quantidade de professores que para a preparação e desenvolvimento das suas aulas usam recursos da internet, muitos desses recursos sendo REA como é possível observar na imagem abaixo. 


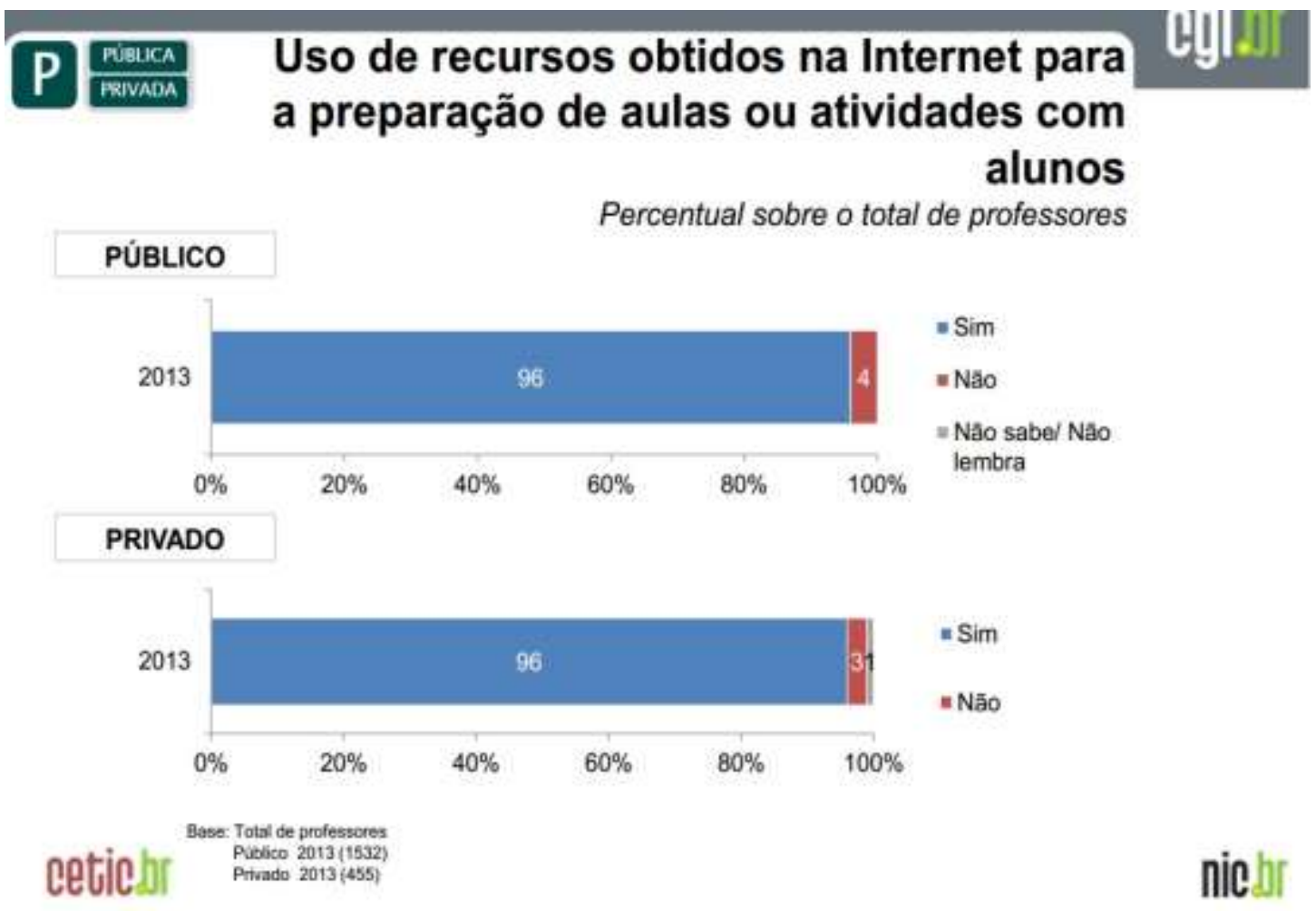

Figura 1 - Gráfico: percentual de professores usuários de recursos da internet.

Fonte: Extraída de CETIC.br (2014, p.10)

Os dados disponibilizados pelo Centro de Estudos sobre as Tecnologias da Informação e da Comunicação - $\operatorname{CETIC}^{7}(2014)$ indicam que $96 \%$ dos professores investigados, sobre uma base total de 1.987 professores em 2013, do setor público e privado, utilizam recursos obtidos na internet em suas aulas. Esse fato demostra a relevância de se estudar as aulas disponibilizadas no Portal do Professor.

Para tanto, este estudo adota uma abordagem quali-quantitativa de pesquisa com método de análise documental. Esta pesquisa identifica o "Espaço da Aula" do Portal do Professor como um espaço de socialização e interação, em que representações de docência da aula de música mediadas pelas NTICs são veiculadas e acessadas. Como Recurso Educacional Aberto-REA, o Portal apresenta princípios fundamentais como o livre acesso, gratuidade, disponibilidade e recurso de domínio público.

No caso da música, alguns materiais de áudio, de vídeo e programas (software) de edição, de jogos musicais, de aprendizado de instrumentos, de bases instrumentais, de bases

\footnotetext{
7 "Em 2012, o CETIC.br foi instituído como Centro Regional de Estudos para o Desenvolvimento da Sociedade da Informação, atuando sob os auspícios da UNESCO, com o objetivo de cooperar com países da América Latina e Lusófonos na África para a construção de sociedades do conhecimento inclusivas." http://www.cetic.br/ página inicial sem paginação.
} 
rítmicas, de bases melódicas ou de bases harmônicas podem ser usados na educação musical, muitos deles encontram-se comercializados com restrições de direitos privados, isso faz com que o recurso chegue a um grupo reduzido e a sua manipulação seja também restrita. Uma vez que muitos objetos de aprendizagem são comercializados, dificilmente eles serão acessíveis pelo Portal, mas o que e como o professor os utiliza nas suas aulas poderá ser analisado.

O desenvolvimento desta pesquisa poderá fornecer subsídios para repensar a aula de música mediada pelas NTICs. Além disso, os princípios de docência identificados poderão orientar modelos didáticos de formação docente que permitirá entender o professor como produtor de saberes e fomentar novas discussões e programas de formação docente em música.

A pesquisa poderá ser também um estímulo à formação continua para o professor de música, um incentivo para pensar o "Espaço da Aula" do Portal do Professor, que poderá ser compreendido para além da concepção de repositório de aulas e de experiências, para ser pensado como um espaço interativo entre comunidades educativas, entre indivíduos e NTICs.

E, de certo modo, esta pesquisa é uma contribuição na ação proposta para alcançar as metas educativas para o século XXI traçadas em 2008 pelos Ministros da Educação da Ibero-América, determinadas com apoio da CEPAL, OEI e a Secretaria Geral Ibero-Americana. Entre elas, modernizar a gestão da educação, profissionalizar e dar protagonismo aos educadores e incorporar as tecnologias da informação e das comunicações ao processo de ensino e aprendizagem.

A estrutura desta Dissertação está composta por cinco capítulos. Esta introdução corresponde ao primeiro. O capitulo segundo descreve, conforme a literatura, os conceitos que contextualizam o Portal do Professor como o conceito de REA. Nele é caracterizado o Portal como um REA e apresentado o Portal do Professor, a sua história, a sua estrutura. Nesse mesmo capítulo é apresentado o elemento "Espaço da Aula", os seus componentes, o seu funcionamento e são apresentadas as pesquisas desenvolvidas sobre o Portal do Professor do MEC.

O terceiro capítulo contextualiza e define a Aula, ele apresenta literatura que discute o planejamento e como este é desenvolvido na aula de música.

A metodologia e seus procedimentos são apresentados no capítulo quarto que, como foi dito, adota uma abordagem quali-quantativa, com método de análise documental. Nele são apresentados os conceitos de abordagem e do método com apoio de autores da literatura pertinente como: Babbie (2005); Bauer et al (2003); Cellard (2008); Flick (2009); Laville \& 
Dionne (1999); e Oliveira (2007). Num segundo momento, descreve-se o processo metodológico seguido nesta pesquisa.

O quinto capítulo aborda a análise e interpretação obtida do processo metodológico, descrevendo as análises quantitativa e qualitativa dos planejamentos da aula disponibilizadas no Portal e concepções e princípios observados nas aulas.

O sexto capítulo está dedicado às considerações finais, deixando aberta a possibilidade de continuação e aprofundamento decorrentes desta Dissertação. 


\section{O ESPAÇO VIRTUAL: RECURSOS E PORTAIS EDUCACIONAIS}

Este capítulo apresenta e descreve o conceito de Recursos Educacionais Abertos (REA), seu contexto tecnológico e político e, consequentemente, o Portal do Professor como um desses recursos, criado e disponibilizado virtualmente para acesso de todos por meio da internet.

Os espaços virtuais conhecidos como REA e Portal são manifestações da Sociedade do Conhecimento, definida por Drucker (1969) e Stehr (1994) como uma proposta de sociedade que além de ter a tecnologia para guardar e partilhar informação tem a capacidade de se apropriar de forma crítica e seletiva dessa informação para reinterpretá-la e convertê-la em novos saberes. Ao se executar essas informações a comunidade toda é beneficiada, contudo, essa deve aceitar a inovação, segundo a seguinte citação: "a base do conhecimento para a sociedade do conhecimento tem de ser capaz de aceitar o novo e diferente, de ser receptiva à inovação." (DRUCKER, 1969, p. 405).

Os limites e possibilidades do ensino e aprendizagem musical na atual Sociedade do Conhecimento, seus recursos e formas de utilizá-los, suscitam o interesse por novos objetos de estudo. Hargreaves (2004) aponta que o termo Sociedade do Conhecimento foi inicialmente usado pelo sociólogo Daniel Bell para descrever a transformação económica pós-industrial abordando mais do que a produção de coisas, mas a produção de conhecimento na ciência, tecnologia, pesquisa e desenvolvimento, como conhecimento flexível e em continuo movimento e como uma sociedade da aprendizagem (HARGREAVES, 2004, p. 30-34).

Ao se falar da Sociedade do Conhecimento está incluindo-se o uso das Novas Tecnologias da Informação e das Comunicações (NTICs) chamadas de "terceira revolução industrial" como destacado por Matsuura (UNESCO, 2005, p.5). Elas têm propiciado as mudanças radicais na evolução humana, da ciência e da técnica e das expressões culturais. São transformações que têm o conhecimento como elemento central, objeto causador do aparecimento de sociedades emergentes em que se partilham o conhecimento, como observado nas palavras do autor, no primeiro Informe da UNESCO sobre a Sociedade do Conhecimento:

Nos nossos dias, se admite que o conhecimento tem convertido-se em objeto de enormes desafios econômicos, políticos e culturais, a tal ponto que sociedades cujos contornos têm um vislumbre podem muito bem ser 
chamadas de sociedades do conhecimento. (MATSUURA, 2005, p.5) [tradução da autora $]^{8}$.

As novas tecnologias não estão baseadas somente na ciência, mas no conhecimento total, elas fazem parte integral da cultura (DRUCKER, 1979, p. 54). As NTICs envolvem diversos recursos como os convencionais impressos (jornal, revistas, correio), a televisão, o rádio, o vídeo, o computador e a internet. Mercado (2004) aponta como características das NTICs a imaterialidade, a interatividade e a instantaneidade. Essas permitem que o conhecimento seja gerado e partilhado por um número maior de pessoas, pois a informação pode ser produzida e transmitida individual ou coletivamente por comunidades ou grupos diversos recriando-se sucessivamente e atingindo lugares distantes.

O uso das NTICs tem propiciado o aparecimento da chamada "cibercultura", baseada na comunicação humana virtualizada e a criação de comunidades virtuais, definidas como: tecido social virtual construído nas teias da Internet por todos os sujeitos a ela conectados (RHEINGOLD apud PASSARELLI, 2007, p. 22).

$\mathrm{O}$ ensino e a aprendizagem com apoio das chamadas NTICs tem se convertido numa corrida pela sua utilização e/ou atualização em todos os níveis e modalidades educacionais. Adota-se aqui o conceito de modalidade educacional no sentido entendido por Libâneo (2012), referindo-se a ela como uma prática educativa da educação intencional e não intencional. Na educação intencional, o autor inclui a aprendizagem formal e a não formal e na educação não intencional, com a aprendizagem informal. Atualmente, entende-se a educação intencional e não intencional como processos educativos complementares e inter-relacionados, consequência da compreensão da educação como uma prática social, em que as modalidades formal, informal e não-formal ocorrem simultaneamente em diferentes contextos como: escola, empresas, hospitais, igrejas, ONGs, internet. Esse fato tem se intensificado com a informação midiatizada e pela "pedagogização" dos processos informais da educação.

No campo da educação escolar, com a "cibercultura" surgem novos conceitos educativos influenciados pelas inovações nas práticas do ensino e da aprendizagem mediadas pelas NTICs, que auxiliam os processos educacionais, facilitando a seleção, organização e produção de saberes. Passarelli (2007) destaca o desenvolvimento das NTICs e aponta autores e a elaboração de conceitos teóricos inovadores como os que propõe Levy, Kerckhove, Pra, Perkins, Gardner. Pierre Levy desenvolve o conceito de "inteligência

\footnotetext{
${ }^{8}$ En nuestros días, se admite que el conocimiento se ha convertido en objeto de inmensos desafíos económicos, políticos y culturales, hasta tal punto que las sociedades cuyos contornos empezamos a vislumbrar bien pueden calificarse de sociedades del conocimiento. (UNESCO, 2005, p.5).
} 
coletiva", ou seja a prática da construção de um saber coletivo em comunidade. O conceito de "inteligência conetiva" ou a construção do saber baseada na interatividade por sistema de redes como a Internet é cunhado por Derrick Kerckhove, Roy Pea, David Perkins, Howard Gardner, entre outros, trabalha com o conceito de "inteligência distribuída" em que se argumenta que a atividade humana é influenciada pelo ambiente local composto por seres humanos e artefatos materiais, culturais, carregados de inteligência e, assim, defendem a existência de uma relação intrínseca entre pensamento, ação e meio ambiente, que resulta no princípio que a cognição é distribuída (PASSARELLI, 2007, pp. 29-55).

No campo da Educação Musical, como apontado por Krüger (2007), a interação com as tecnologias, o trabalho em equipe e a aprendizagem colaborativa entre os envolvidos no processo educativo representam formas inovadoras para a construção de conhecimento:

O uso das Tecnologias da Informação e Comunicação (doravante TICs) nas escolas também ressalta a importância das interações entre professor e seus alunos e entre os próprios alunos. Mais do que nunca, está claro que o professor não será substituído pelas tecnologias, e que ele é fundamental para, junto com o aluno, construir conhecimento. É essa proposta de estar junto que atribui o caráter interativo da profissão também no âmbito das tecnologias educacionais como ocorre nos Ambientes Virtuais de Aprendizagem (doravante AVA) (KRÜGER, 2007, p.98).

O ensino e aprendizagem de música e a investigação em educação musical, aproveitando do estímulo institucional e dos programas do Ministério de Educação, transitam na atualidade em Ambientes Virtuais de Aprendizagem (AVA), em Comunidades Virtuais de Aprendizagem, em Repositórios de Objetos Virtuais de Aprendizagem, em Portais educacionais e outros recursos tecnológicos e midiáticos que fazem parte dos Recursos Educacionais Abertos (REA), do inglês Open Education Resources (OER).

Nesse contexto, as inovações educativas propiciadas pelas NTIC e pela cibercultura, configuram novos tipos de interação como a Internet, em que a produção do conhecimento emerge em novas configurações de ensino e de aprendizagem e novas estratégias e recursos como os REA que têm propiciado novas formas de produzir e divulgar o conhecimento. No próximo tópico apresentamos o REA e sua importância na socialização do trabalho docente.

\subsection{RECURSOS EDUCACIONAIS ABERTOS - REA}

Uma das grandes recomendações e compromisso da Organização das Nações Unidas para a Educação, a Ciência e a Cultura (UNESCO) é a de velar para que as fontes da 
informação e do conhecimento, de domínio público, sejam accessíveis a todos, como bem e desenvolvimento para e por todos. A UNESCO defende o acesso universal ao conhecimento, se observando os direitos dos produtores e dos usuários.

O acesso universal ao conhecimento deve continuar a ser o pilar sobre o qual se baseia a transição para sociedades do conhecimento. A promoção efetiva desse acesso é um equilíbrio entre os direitos dos titulares de direitos, por um lado, e dos usuários de conteúdo cognitivo, do outro lado, assim mesmo como entre os dispositivos de proteção da propriedade intelectual e o conhecimento ou a informação de domínio público. Dentro dessa perspectiva, a UNESCO tem o compromisso de "promover o acesso livre e universal à informação de domínio público para fins de educação, ciência e cultura" e, por essa razão, a comissão aprovou em 2003 a Recomendação sobre a promoção e uso de plurilinguismo e acesso universal ao ciberespaço. (UNESCO, 2005, p.186, tradução da autora) ${ }^{9}$.

Motivados pelo compromisso proposto pelo texto da UNESCO, diversos projetos surgem como o REA ou o OER. Esse se manifesta como projeto e como movimento educacional dinâmico, cuja ideia central é a que o "conhecimento do mundo é um bem público e que a tecnologia em geral e a World Wide Web em particular, como proporcionam uma oportunidade para que todos possam compartilhar, usar e reutilizar o conhecimento" (SMITH; CASSERLY, 2006, pp. 8-17).

Definidos como materiais oferecidos livre e abertamente para educadores, estudantes e autodidatas, utilizarem e reutilizarem no ensino, na aprendizagem e na pesquisa, os REAs são definidos como: "provisão de recursos educacionais com licença aberta, habilitados por informações e tecnologias de comunicação, para consulta, utilização e adaptação por uma comunidade de usuários para fins não comerciais" (UNESCO, 2002, p.24, tradução da autora) ${ }^{11}$.

No Brasil, na Universidade de Campinas (UNICAMP) foi organizado em 2002 um trabalho com REA sob coordenação do professor Tel Amiel, investigador do Núcleo de

\footnotetext{
${ }^{9}$ El acceso universal al conocimiento debe seguir siendo el pilar en el que esté basada la transición hacia las sociedades del conocimiento. La promoción efectiva de ese acceso supone un equilibrio entre los derechos de los titulares de derechos, por un lado, y los de los usuarios de los contenidos cognitivos, por otro lado, así como entre los dispositivos de protección de la propiedad intelectual y el conocimiento o la información de dominio público. Dentro de esta perspectiva, la UNESCO se ha comprometido a "promover el acceso libre y universal a la información de dominio público a los fines de la educación, la ciencia y la cultura" y para ello aprobó en 2003 la Recomendación sobre la promoción y el uso del pluriligüismo y el acceso universal al ciberespacio. (UNESCO, 2005, p.186).

${ }^{10}$ At the heart of the movement towards Open Educational Resources is the simple and powerful idea that the world's knowledge is a public good and that technology in general and the Worldwide Web in particular provide an opportunity for everyone to share, use, and reuse it. (SMITH; CASSERLY, 2006, pp. 8-17)

${ }_{11}$ "The open provision of educational resources enabled by information and communication technologies, for consultation, use and adaptation by a community of users for non-commercial purposes" (UNESCO, 2002, P.24).
} 
Informática Aplicada à Educação, como um projeto com interesses na educação/tecnologia/cultura de cooperação Brasil/EUA.

Mais tarde Carolina Rossini fundou em 2008 o projeto REA Brasil, que, como descrito na aba da página REA Brasil (www.rea.net.br) a respeito da historia, aconteceu com a visita de uma delegação internacional ao Ministério da Educação e a realização de uma série de eventos de sensibilização em São Paulo e Brasília. O projeto adota a seguinte definição para REA:

Recursos Educacionais Abertos são materiais de ensino, aprendizado e pesquisa em qualquer suporte ou mídia, que estão sob domínio público, ou estão licenciados de maneira aberta, permitindo que sejam utilizados ou adaptados por terceiros. $\mathrm{O}$ uso de formatos técnicos abertos facilita o acesso e o reuso potencial dos recursos publicados digitalmente. Recursos Educacionais Abertos podem incluir cursos completos, partes de cursos, módulos, livros didáticos, artigos de pesquisa, vídeos, testes, software, e qualquer outra ferramenta, material ou técnica que possa apoiar o acesso ao conhecimento (Comunidade REA Brasil, 2011).

O termo "aberto", popularizado com o auge das NTICs tem sido definido e aplicado em vários contextos dentro da prática do ensino e da aprendizagem. No REA, ele responde: à liberdade do uso de um recurso; à licença aberta; à amplitude do alcance e à gratuidade no caso do sistema de abertura da Universidade Aberta do Brasil-UAB, por meio da rede pública de educação a distância.

Inamorato (2012) aponta a necessidade de se definir os termos e terminologias utilizados. "Licença aberta" se refere à autoria e ao tipo de uso. O "código aberto" é o tipo de software; o "acesso aberto" se refere ao acesso às publicações científicas. Open Courseware se refere a cursos com REA e Massive Open Online Course (MOOC) é entendido como aprendizagem distribuída em rede com cursos massivos em rede. A definição de REA é polissêmica e pode ser expressa de forma abrangente como Inamorato (2012) apresenta na citação abaixo:

Recursos educacionais abertos podem ser considerados componentes (ou estratégias/práticas) da educação aberta, que é praticada atualmente dentro de uma perspectiva de compartilhamento de conteúdo digital com licença de uso aberta. (INAMORATO, 2012, p. 83).

A autora enfatiza a condição da "licença aberta" para os REA. Pode-se afirmar que a criação de licenças Creative Commons (CC) permitiu o fortalecimento internacional do REA, ampliando o seu número e os tipos de REA. Nessas licenças, o autor decide o que quer e 
como quer que o usuário utilize o recurso. A utilização permite ao usuário certas práticas de uso sem infringir direitos autorais, como cópia, compartilhamento, modificação e distribuição e segundo a eleição do autor, se permite o uso da obra com ou sem fins comerciais

As licenças Creative Commons (CC) identificam-se assim: 1) $C C / B Y$ indica a permissão menos restritiva, com ou sem fins comerciais; 2) $C C / B Y / S A$ indica permissão comercial, porém, os derivados deverão apresentar-se com idêntica licença, isto assegura que o recurso seja compartilhado com a mesma licença aberta; 3) $C C / B Y / N D$ atribui uso comercial, contudo, com licença não derivativa, pelo tanto, o uso da obra deverá se completa e sem modificações; 4) $C C / B Y / N C$ para licença não comercial, com atribuições para remixar, adaptar e criar obras derivadas; 5) $C C / B Y / N C / S A$ licença para uso não comercial com a qual pode-se combinar ou partilhar, as obras derivadas da original licenciada devem ter idêntica licença; 6) $C C / B Y / N C / N D$ indica a permissão mais restritiva, sem uso comercial e sem derivações, permite-se usar e partilhar mas sem nenhuma modificação.

Com base no critério de licença aberta surgem as principais características dos REA, que podem ser associadas a quatro erres (Rs): Re-usar, Re-visar, Re-mixar e Re-distribuir.

1) Re-usar corresponde a usar o conteúdo na sua forma original ou modificada, podendo-se utilizar uma ou várias partes, imprimir, gravar ou realizar cópias;

2) Re-visar é entendido como adaptar, modificar ou alterar como por exemplo adicionar imagens, traduzir;

3) Re-mixar significa combinar com outros recursos criando algo novo;

4) Re-distribuir no sentido de compartilhar com outras pessoas.

O REA encontra-se em fase de expansão multiplicando-se em todos os países e continentes. Em 2007, a Organização de Cooperação e de Desenvolvimento Económico (OCDE, 2008, p. 57) identificou mais de três mil (3.000) cursos e materiais REA disponibilizados por mais de 300 universidades no mundo. Um desses exemplos identificados foi a Multimedia Educational Resource for Learning and Online Teaching (MERLOT), sendo um programa da Universidade do Estado de Califórnia em associação com instituições de educação, sociedades profissionais e da indústria. No que se refere à música tem-se a International Music Score Library Project (IMSLP), que é uma biblioteca internacional de partituras de domínio público.

No Brasil e em países da América Latina, os projetos que envolvem REA têm obtido, nos últimos anos, apoio direto ou indireto do Estado, seja por meio de instituições criadas especificamente para tal fim, seja por meio de mediadas ou programas ligados aos Ministérios 
de Educação desses países, que em vários casos, são ligados a redes internacionais. A Rede de Portais Educativos da América Latina (RELPE) é um exemplo de projeto no âmbito governamental, do qual faz parte o Portal do Professor do Ministério de Educação do Brasil. Entre outros, destaca-se ainda: o programa Centro de Educación y Tecnología (Enlaces) do Chile, criado em 1992 pelo Ministério de Educação do governo Chileno; o Colombia Aprende, Portal educativo criado em 2004 pelo Ministério de Educação Nacional da Colômbia; o EducaRede criada em 2003 pela Fundação Telefônica e o Conselho Nacional de Desenvolvimento Científico e Tecnológico - CNPq do Ministério de Ciência, Tecnologia e Inovação de Brasil.

No contexto do Brasil, segundo Rossini (2010), o REA-OER apresenta-se em quatro eixos que entrelaçam estruturas da educação tradicional e das redes digitais para o uso e difusão de materiais educativos. A autora destaca o acesso público, o ciclo econômico e o direito de aprender, os benefícios do REA e o desenvolvimento profissional de professores. Em suas palavras:

- o acesso público a materiais educacionais em geral, bem como uma estratégia de educação aberta para incluir o indivíduo, a família, a comunidade e toda a sociedade no processo de aprendizagem e de produção colaborativa de conhecimento;

- o ciclo econômico de produção de materiais educacionais e seu impacto no "direito de aprender dos cidadãos";

- os possíveis benefícios que os REA podem trazer para as estratégias de aprendizagem, para a produção de recursos educacionais mais apropriados à diversidade regional e aos padrões regionais de qualidade;

- impacto dos recursos digitais, online e abertos no desenvolvimento profissional continuado dos professores. (ROSSINI, 2012, pp.42-43)

No Brasil, Rossini (2010, pp. 57-71) destaca projetos desenvolvidos com apoio dos Ministérios de Educação (MEC) e da Ciência, Tecnologia e Inovação (MCTI):

1. Universidade Aberta (UAB), criada em 2005 e coordenada pelo Ministério de Educação do Brasil (MEC) uma rede de instituições e universidades que têm como objetivo difundir a Educação Superior para municípios onde ela não é oferecida.

2. Repositórios Educacionais Digitais, criados desde 2003, dentre os quais estão: Rede de Recursos Educacionais Interativos (RIVED); Banco Internacional de Objetos Educativos (BIOE), repositório criado em 2008 que integra parte da Rede Latino-americana de Portais Educativos - RELPE; Banco Digital de Teses e Dissertações - BDTD, criado em 
2002 pelo Instituto Brasileiro de Informação em Ciência e Tecnologia e o Ministério de Ciência e Tecnologia, cuja missão é disponibilizar a produção acadêmica nacional no âmbito nacional e internacional. Este, desde 2006, é coordenada pela Coordenação de Aperfeiçoamento de Pessoal de Nível Superior (CAPES)

3. SciELO Books - Scientific Electronic Library Online, desde 1997 é uma rede de coleções de periódicos científicos atualmente dirigido pelo Conselho Nacional de Desenvolvimento Científico e Tecnológico (CNPq).

4 Portal do Professor, lançado em 16 de junho de 2008 como membro do RELPE e criado pelo Ministério de Educação (MEC) e as Secretarias Estaduais e Municipais de Educação para a integração e interação do sistema de educação pública.

Esses projetos têm recebido apoio de diversas iniciativas e propostas de políticas públicas municipais, estaduais e federais que incentivam a criação de novos projetos e programas, bem como a ampliação, atualização e uso dos REA existentes.

\subsection{PORTAL DO PROFESSOR}

Desde o ano 1995, a partir das recomendações do informe Delors da UNESCO, se nota uma grande e continua movimentação nas orientações para o uso das Novas Tecnologias da Informação e das Comunicações (NTICs) favorecendo o ensino e a aprendizagem escolar. As NTICs são entendidas como fator imprescindível para alcançar patamares de educação de qualidade em igualdade de condições para todos, como observado a seguir pelo referido documento: "divulgar as novas tecnologias da chamada sociedade da informação para todos os países, a fim de evitar o agravamento do fosso entre países ricos e pobres" (DELORS, 1995, p.29, tradução da autora) ${ }^{12}$.

No mesmo relatório, descreve-se a educação para todos como principal ponto de partida para avançar no desenvolvimento dos povos e na solução dos problemas de dimensão mundial. Dentre as ações propostas se destaca o estímulo ao desenvolvimento de Recursos Educacionais Abertos (REA). Esse é um dos projetos que tem sido desenvolvido para atender

\footnotetext{
12 "Difundir las nuevas tecnologías llamadas de la sociedad de la información en favor de todos los países, a fin de evitar una agudización aún mayor de las diferencias entre países ricos y pobres." (Informe de la Comisión Internacional sobre a Educación para el siglo XXI- 1995, p.29).
} 
às recomendações realizadas pela Comissão Internacional sobre Educação para o Século XXI, descritas no Informe Delors (1995) acima mencionado.

Um dos projetos desenvolvidos como REA e que atende às recomendações de estímulo ao uso das NTICs na educação é a Rede Latino-americana de Portais Educativos (RELPE), criada em 2004 pelo acordo dos ministros da educação de 16 países de América Latina reunidos para tal fim em Santiago de Chile. Dentre os portais membros do RELPE encontram-se: "Colombia aprende"; "Educar", portal da Argentina, relançado em 2003 e membro do RELPE desde 2004; "Educarchile" criado em 2001 com a ligação da Rede Enlaces $^{13}$ do Ministério de Educação e a Fundação Chile; "SEPiensa" portal de México; "PERÚEDUCA" membro do RELPE desde 2004. Para a RELPE os portais educativos permitem a integração das tecnologias da informação e das comunicações na educação, assegurando uma distribuição que atinge a comunidade educativa toda quando assim precisar, disponibilizando recursos digitais para professores, estudantes e investigadores, além de ser um meio natural de formação continuada, de troca e discussão de experiências, de gestão escolar e de atualização.

Nesse sentido, o Portal do Professor do MEC se apresenta como um dos projetos REA desenvolvidos com fins educativos e de formação docente. Porém, na sua origem, segundo relata Inamorato (2013), o portal foi criado para ampliar o acesso a recursos digitais para professores e alunos. Posteriormente, devido ao fortalecimento internacional do movimento REA, o governo, quem subsidia o projeto, reviu a licença de uso para que o Portal pudesse adquirir os requisitos especiais para se considerar REA. A esse respeito Inamorato (2013) afirma:

Essas iniciativas não foram originalmente criadas para serem REA, mas sim para ampliar o acesso a conteúdos digitais para professores e educandos. $\mathrm{Na}$ ocasião em que essas iniciativas foram criadas, na década de 90 , não existia ainda o conceito de REA. Ele foi cunhado num congresso da UNESCO em 2002. Hoje em dia, é possível perceber que algumas dessas iniciativas já mudaram ou estão em processo de mudança da sua licença de uso, como um todo e/ou em seus recursos individualmente, como é o caso do Portal do Professor do Ministério da Educação (MEC) em parceria com o Ministério da Ciência e Tecnologia (atualmente MCTI) (INAMORATO, 2013, p.8).

O Portal do Professor do MEC foi especialmente criado para a comunidade educativa, como um apoio de comunicação em rede, via Internet, para acesso a informações de modo

\footnotetext{
13 Projeto modelo criado em 1992, visando constituir una rede educacional em todo o território chileno incorporando as NTICs à educação.
} 
amplo e irrestrito com fomento das NTICs e para a participação do Brasil no RELPE. Como mencionado, o Portal foi criado pelo Ministério de Educação e as Secretarias Estaduais e Municipais de Educação em 2007, visando a integração e interação do sistema de educação pública, como expressado a seguir:

Visando fomentar a participação de nossos professores em comunidades educacionais, com a oferta de conteúdos digitais, espaços de comunicação e outros elementos foram criado em 2007 o Portal do Professor, que iniciou sua operação em 2008 (BIELSCHOWSK; PRATA, 2010, p.2).

Para Bielschowsk e Prata (2010), o Portal é também uma motivação para o uso das TIC em sala de aula, dando continuação aos planos de ação do Programa Nacional de Formação Continuada em Tecnologia Educacional - ProInfo Integrado ${ }^{14}$. Para a sua concepção e implementação houve a colaboração de universidades públicas, faculdades, colégios, empresas, fundações e instituições públicas e privadas.

O Portal, no seu início em 2008, era acessível somente na Língua Portuguesa, atualmente, ele está disponível também na Língua Espanhola. Frequentemente ele é visitado tanto por usuários do território brasileiro quanto por usuários de outros países como observado na Tabela 1 a seguir.:

Tabela 1 - Acessos ao Portal desde o seu lançamento em 16 de junho de 2008 até Setembro de 2013.

\begin{tabular}{llll}
\hline \multicolumn{2}{c}{ MUNDO } & \multicolumn{2}{c}{ BRASIL } \\
\hline Acessos dentre 208 países & \multicolumn{2}{l}{ Acessos dentre 1127 cidades. } \\
\hline Portugal & 905.287 & São Paulo & 4.252 .575 \\
Estados Unidos & 152.448 & Rio de Janeiro & 3.135 .833 \\
\hline Angola & 50.854 & Belo Horizonte & 3.017 .002 \\
Argentina & 23.316 & Salvador & 1.966 .194 \\
\hline Japão & 21.308 & Curitiba & 1.413 .020 \\
Espanha & 17.803 & Brasília & 1.327 .436 \\
\hline México & 13.782 & Recife & 1.299 .286 \\
& & Total de acessos 44.213.236 \\
\hline
\end{tabular}

Fonte: Autora, dados extraídos de http://portaldoprofessor.mec.gov.br/estatisticasVisita.html Acesso em: 1 Set. 2013.

Nas suas estatísticas, desde o seu lançamento, o Portal tem registrado um aumento nos acessos, dados que têm sido atualizados em diferentes momentos. Na figura 4 a seguir,

\footnotetext{
${ }^{14}$ Programa de formação do Ministério da Educação, voltado para o uso didático-pedagógico das Tecnologias da Informação e Comunicação (TIC) no cotidiano escolar. Programa Nacional de Formação Continuada em Tecnologia Educacional (ProInfo Integrado).
} 
observa-se a estatística disponibilizada pelo Portal em 31 de Agosto de 2013 em que é possível observar o crescimento de acessos no período de 2008 a 2013:

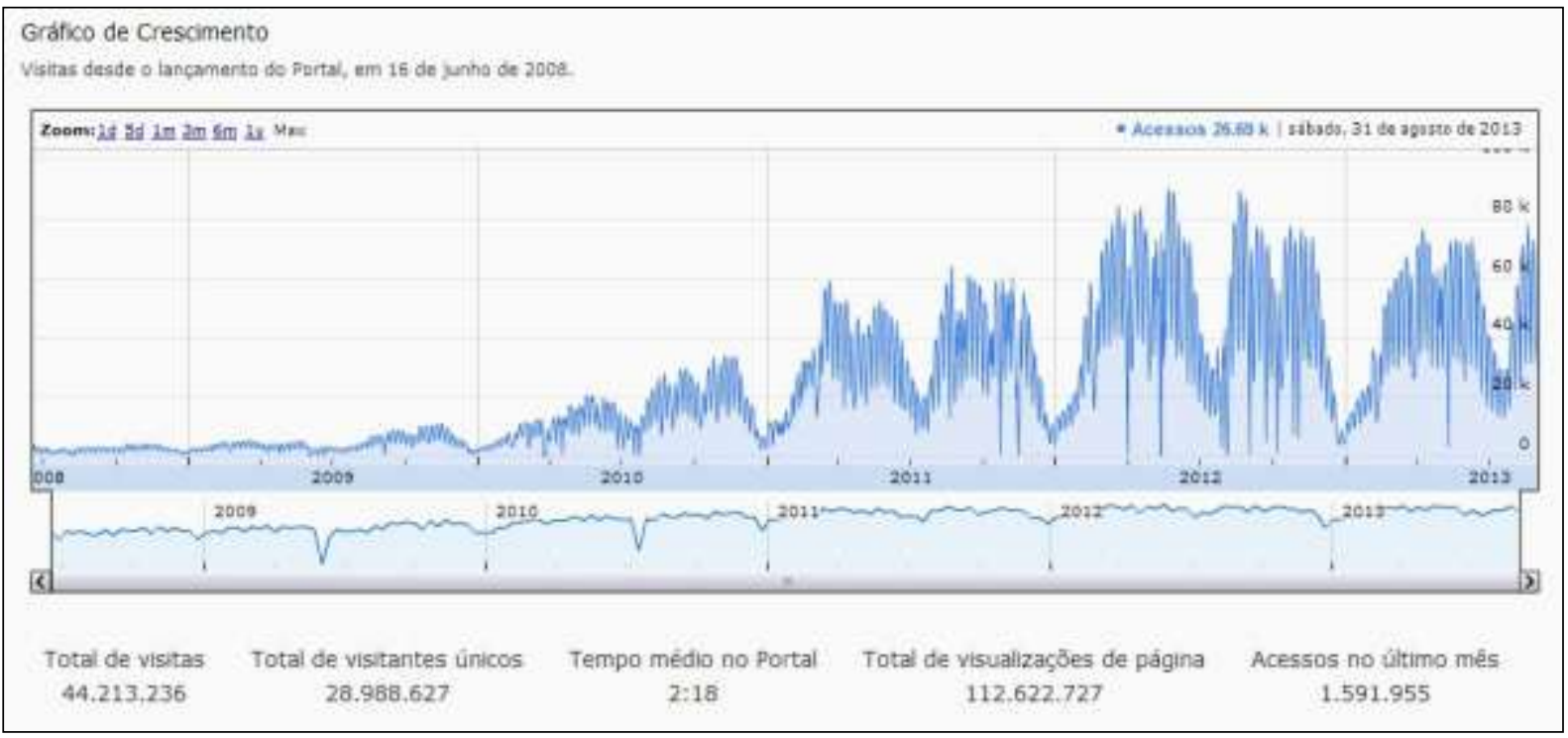

Figura 4 - Dados estatísticos de acessos ao Portal do professor do MEC.

Fonte: Portal do Professor, Extraído de http://portaldoprofessor.mec.gov.br/estatisticasVisita.html Acesso em: 31 Ag. 2013.

O Portal nos seus primeiros anos estruturou-se em seis "grandes áreas" "15: Elas são apresentadas em sua página inicial na forma de links ou páginas que podem ser acionadas. As opções de navegação são : 1) "Espaço da Aula"; 2) "Jornal do Professor"; 3) "Conteúdo Multimídia"; 4) "Cursos e Materiais"; 5) "Interação e Comunicação"; 6) "Links". A sétima aba, "Plataforma Paulo Freire" dá acesso ao Plano Nacional de Formação dos Professores da Educação Básica - PARFOR. Cada uma das grandes áreas está composta por subáreas, também na forma de links para serem acionados.

Na figura 2 a seguir, observa-se a página inicial do Portal do Professor como foi apresentada nos seus primeiros cinco anos, desde a sua disponibilidade ao público em 16 de junho de 2008 até as primeiras semanas de novembro de 2013 quando houve alteração e atualização do layout da página:

\footnotetext{
${ }^{15}$ O termo "grande área" é uma terminologia usada pelo próprio Portal.
} 


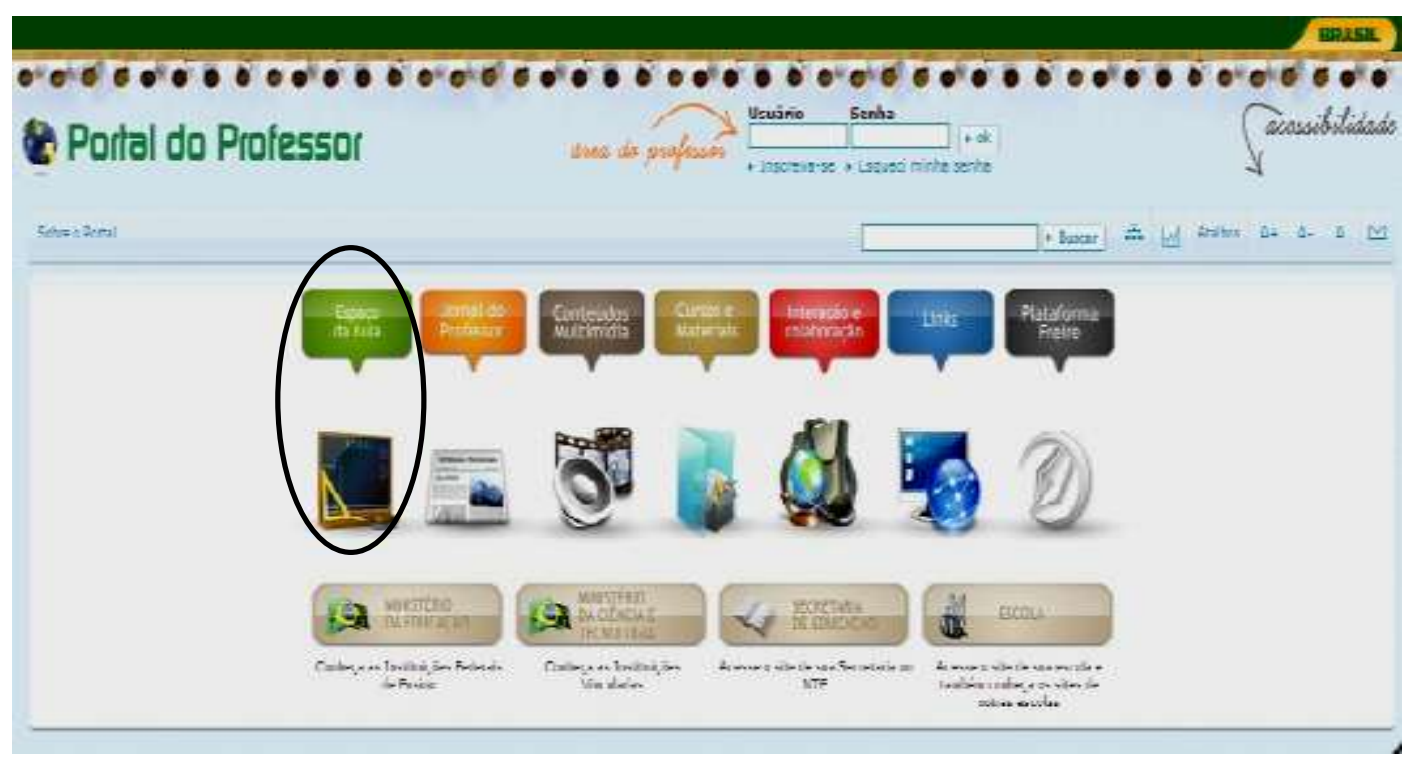

Figura 2 - Palgina inicial do Portal do professor do MEC.

Fonte: Extraída de http://portaldoprofessor.mec.gov.br/index.html Acesso em: 24 de Out.de 2013

As mudanças efetuadas em 2013 nas "interfaces” do Portal, tanto na página inicial que apresenta as grandes áreas de navegação, quanto nas páginas secundárias que direcionam cada link da grande área a novas opções, apresentam nova organização de conteúdo. Contudo, as mudanças foram efetivadas, principalmente, no layout da página: suas cores, imagens, logos das grandes áreas e elementos dentro dessas, como observado na figura 3 a seguir:

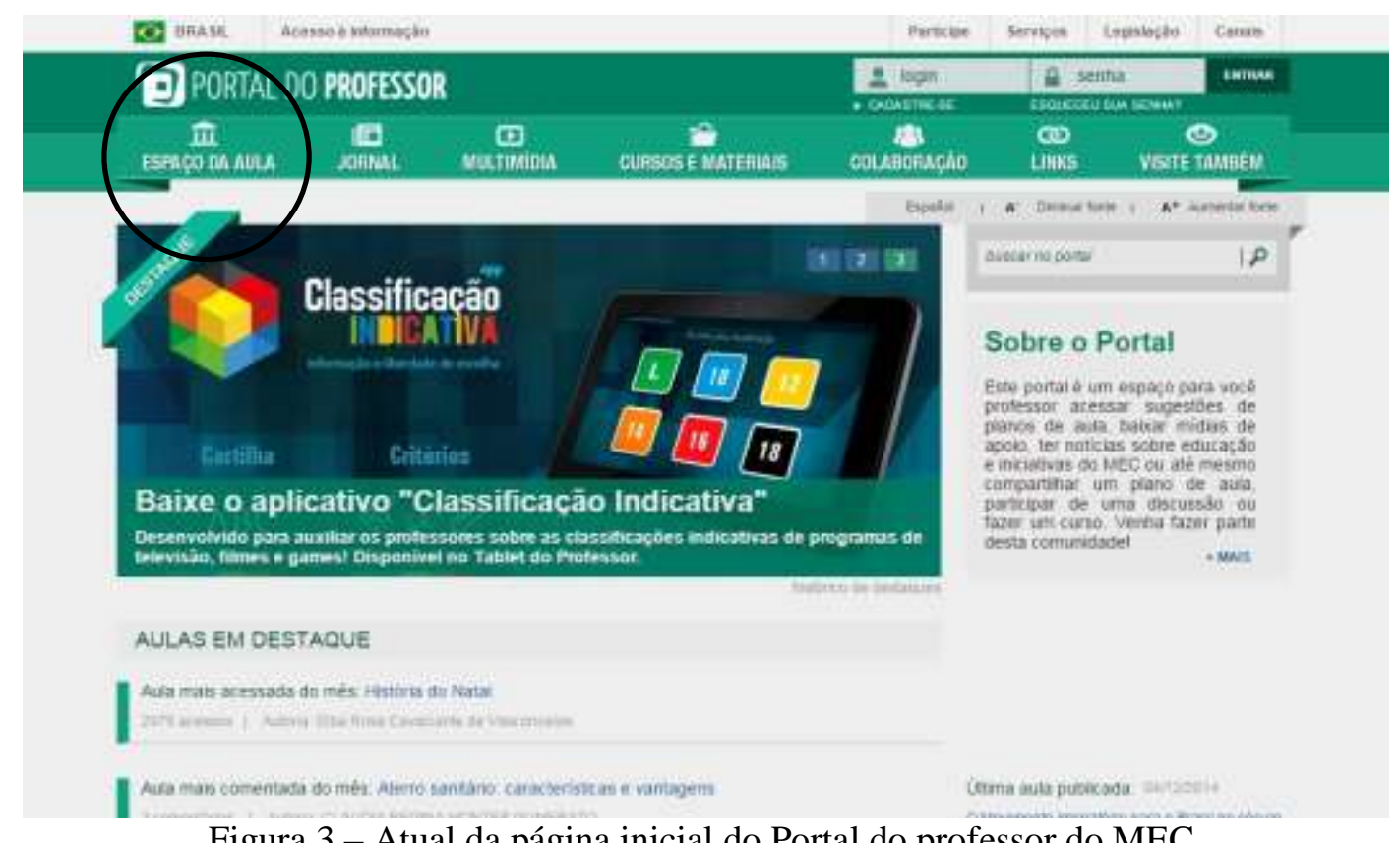

Figura 3 - Atual da página inicial do Portal do professor do MEC.

Fonte: Extraída de: http://portaldoprofessor.mec.gov.br/index.html Acesso em: 5 de Dez.de 2014 
Com relação ao layout inicial, são mantidas as sete abas com as seis grandes áreas do Portal. Contudo, a nomenclatura das abas foi simplificada ou alterada: os termos "Espaço da Aula", "Cursos e Materiais" e "Links" foram mantidos e as abas "Jornal do Professor", "Conteúdos Multimídias", "Interação e Colaboração" foram simplificadas, respectivamente, para "Jornal", "Multimídia" e "Colaboração". A aba de acesso a "Plataforma Freire" foi mantida. Depois, em layout mais recente o link para a "Plataforma Freire" foi incluído numa nova aba denominada "Acessos" e a última mudança para essa aba até 5 de dezembro do 2015 leva o nome de "Visite Também". Nessa o usuário poderá acessar também, outros programas e recursos do MEC: Domínio Público, E-PROINFO, Objetos Educacionais e TV Escola.

Segundo o novo layout, as seis grandes áreas apresentam especificidades de conteúdo e interatividade que são também complementares. Na grande área "Espaço da Aula", em destaque nas figuras acima, o professor usuário pode produzir e compartilhar aulas. No "Jornal", o professor usuário pode acessar as informações sobre prática educacional. O acesso a recursos multimídia e seu download é realizado pela grande área "Multimídia". Essa tem acesso a sites temáticos diversos; tv escola; cadernos didáticos; recursos tecnológicos como: vídeo, hipertexto, imagem, áudio, simulação, software. Na grande área "Cursos e Materiais", o professor usuário pode acessar a materiais e cursos. A “Colaboração" possibilita a interação e colaboração entre colegas. Na opção "Links" o usuário pode acessar a diversas temáticas, entre os quais: museus, bibliotecas e outros portais. Por último, em 2010, foi anexada a aba "Plataforma Paulo Freire", hoje com nome "Visite Também", onde o professor usuário pode acessar à Plataforma Freire, sistema eletrônico de gestão e acompanhamento do Plano Nacional de Professores da Educação Básica; pode ter acesso direto ao Banco Internacional de Objetos Educacionais (BIOE) com conteúdo em diferentes idiomas.

Observou-se -se ainda que o Portal disponibiliza acesso à aula de música em outras abas que acionam diferentes links ou páginas de uma "grande área", como, a grande área "Multimídia" na que o professor encontra elementos em formato de links para usar no planejamento da aula de música como: imagem; som; vídeo ou programas (software) de gravação ou criação de música. Acionando um desses elementos e buscando pela palavra-chave "música" o usuário também encontra opções de aula de música. Essa opção permite a interdisciplinaridade entre música e outras disciplinas e entre conteúdos.

Apresentado o Portal do Professor, segue a descrição da grande área "Espaço da Aula" a partir das duas versões visualizadas durante este estudo: a primeira (versão 1) apresenta a 
aparência original desde a disponibilidade pública do portal e a segunda (versão 2), apresenta as alterações da aparência observadas nas primeiras semanas de novembro do 2013.

No "Espaço da Aula" encontram-se os planejamentos de aula de música que são analisados nesta pesquisa.

\subsection{1 "Espaço da Aula"}

O "Espaço da Aula" do Portal do Professor apresenta quatro ferramentas de navegação, essas são links ou páginas apresentadas em abas superiores: 1) "Sugestões de Aula", 2) "Criar Aula", 3) "Minhas Aulas" e 4) "Orientações”. Segue uma breve descrição.

Na visualização do "Espaço da Aula", destaca-se a aba "Sugestões de Aulas", como apresentado inicialmente, na versão 1 . Observam-se na figura 4 as quatro ferramentas de navegação acima mencionadas:

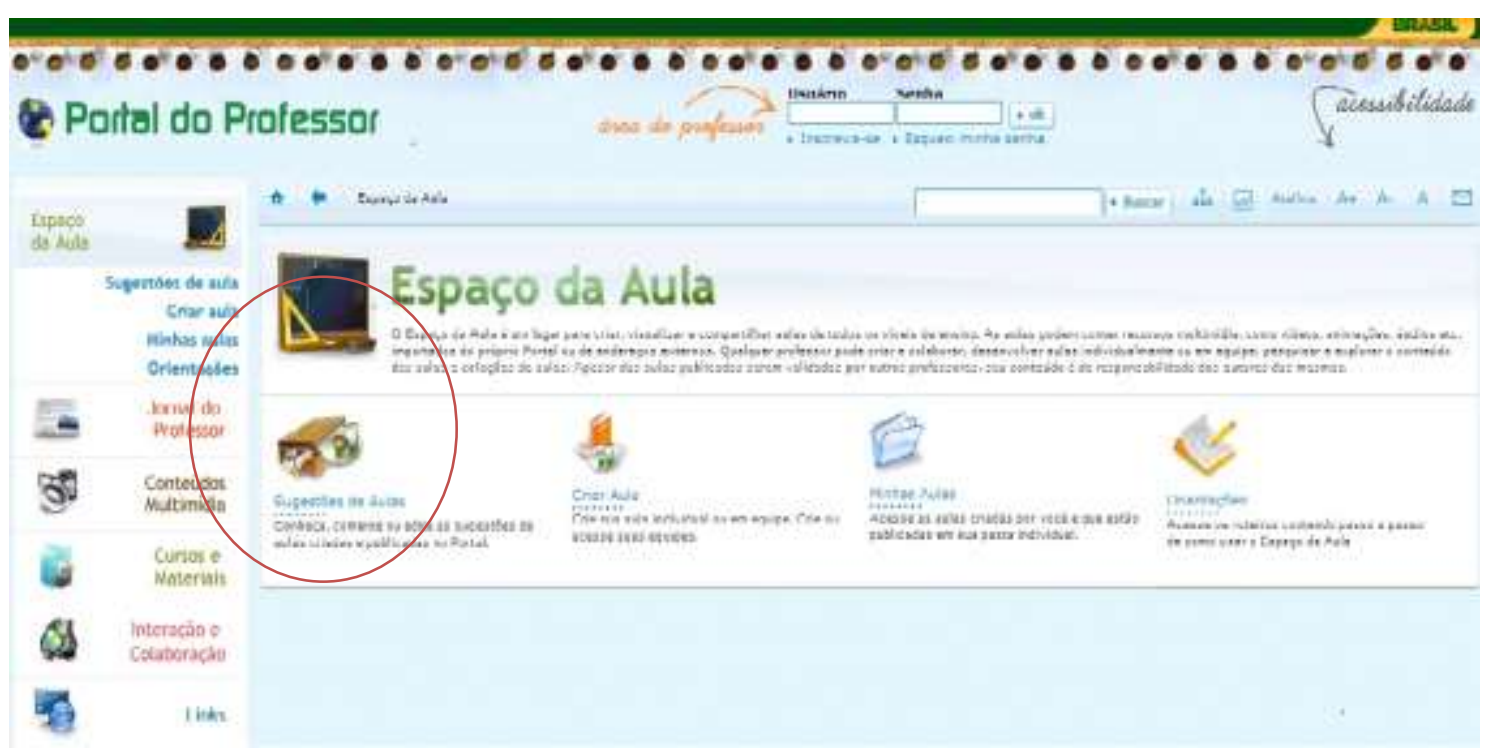

Figura 4 - Pagina do "Espaço da Aula".

Fonte: Extraída de http://portaldoprofessor.mec.gov.br/index.html Acesso em: 8 Mai de 2013.

A aba "Sugestões de Aulas" apresenta link ou página a ser acionada pelo usuário que tem acesso aos novos elementos "Aulas" e "Coleções de Aulas". Esses também são disponibilizados como link ou páginas a ser acionadas. "Sugestões de Aulas" é um espaço em que são disponibilizadas as aulas planejadas pelos professores. Na segunda aba apresentada como link ou página, "Criar Aula", o usuário tem acesso a novos elementos: "criar 
individual"; "criar em equipes" e "gerenciar equipes". Esses são apresentados também como links que podem ser acionados. Nessa aba, o usuário tem a opção de planejar aulas individualmente ou em equipe. A grande área "Espaço da Aula" apresenta o elemento em forma de link "Minhas Aulas", que ao ser acionado o usuário, com prévio cadastro no Portal, tem acesso à criação do se próprio arquivo individual e pessoal disponibilizado para guardar as aulas criadas e publicadas ou para guardar as aulas acessadas. Por fim, na aba apresentada como link ou página "Orientações", na versão 1, o usuário acessava a novos elementos apresentados em forma de link: "Reflexões pedagógicas"; "Criando equipes no Portal"; "Utilizando a ferramenta de criação de aulas" e "Dicas para a produção de aulas". Atualmente, na versão 2, são disponibilizados dois links ou páginas a ser acessados com nome de "Criando equipes" e "Como criar uma aula", apresentados no formato PDF como tutoriais.

Com relação a aba "Sugestões de Aula", em levantamento realizado em setembro de 2013 foram identificadas 14.104 postagens para o elemento "Aulas" e a quantidade de 826 grupos de aulas organizadas no elemento "Coleções de Aula". Nessas páginas, o professor pode acessar aulas de música ou coleções de aulas de música.

Para se criar uma aula, o Portal exige prévio cadastramento e que o usuário seja professor ou aluno de licenciatura. No processo de criação, o portal fornece um formato a ser preenchido sequencialmente e sugere conceitos pedagógicos para serem observados e adotados.

A seguir, duas apresentações das imagens do layout da página inicial do "Espaço da Aula" do Portal na sua nova apresentação alterada nas primeiras semanas de novembro de 2013: 


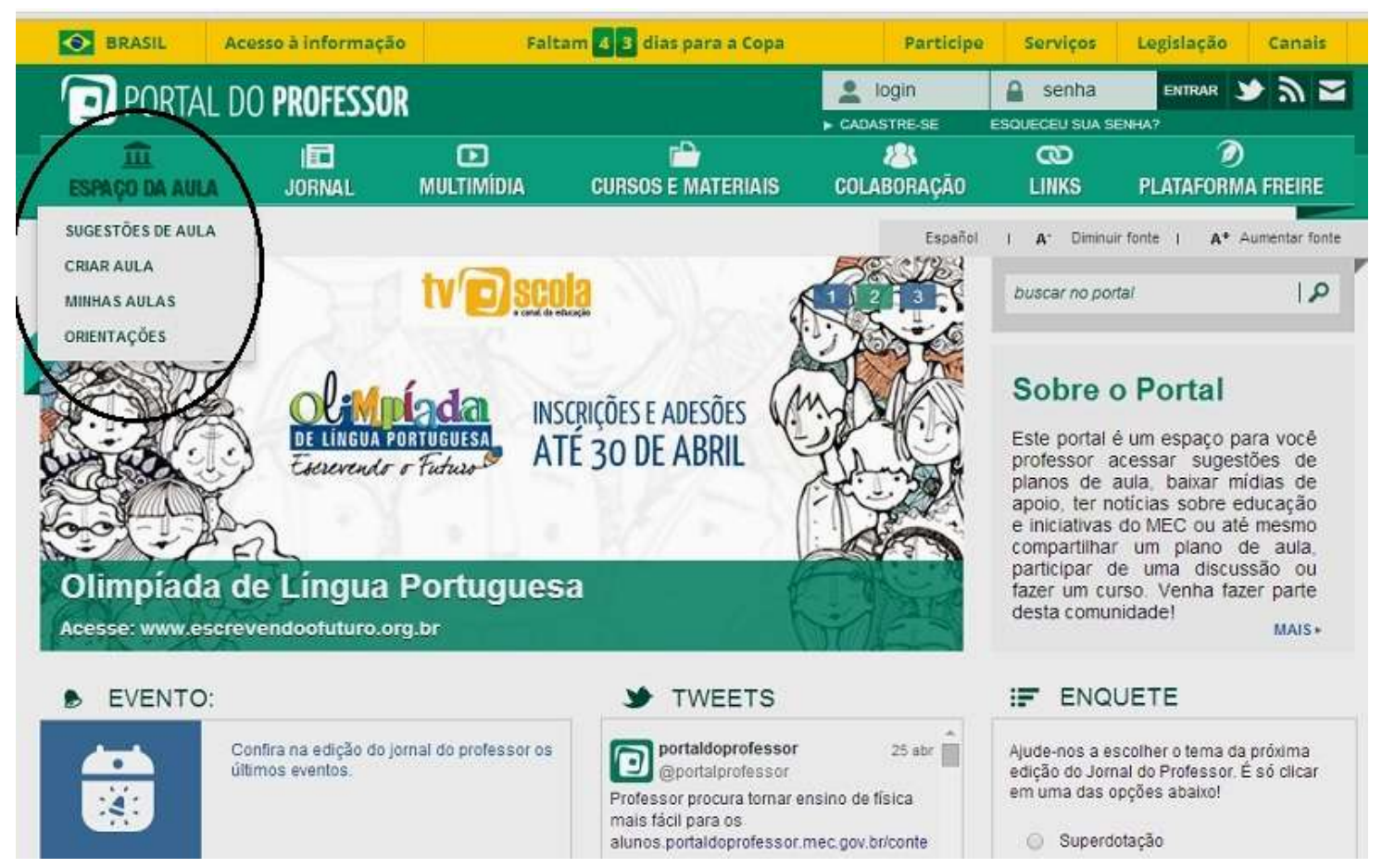

Figura 5 - Atual Pagina do "Espaço da Aula".

Fonte: Extraída de http://portaldoprofessor.mec.gov.br/index.html Acesso em: 7 Abr. de 2014

Na página inicial atual, observamos no menu as abas ou links que dão acesso às páginas internas do Portal. O usuário ao passar o cursor por cada link observa as opções de abas que pode acessar, com a possibilidade de ir diretamente ao elemento de interesse ou acessar a página da grande área.

A imagem a seguir apresenta o desenho da página "Espaço da Aula", ao ser acionado o link disponibilizado no mеnu principal do Portal se observam os elementos ou novas páginas disponibilizadas como abas que o usuário tem acesso aos novos elementos ou páginas descritas acima: 


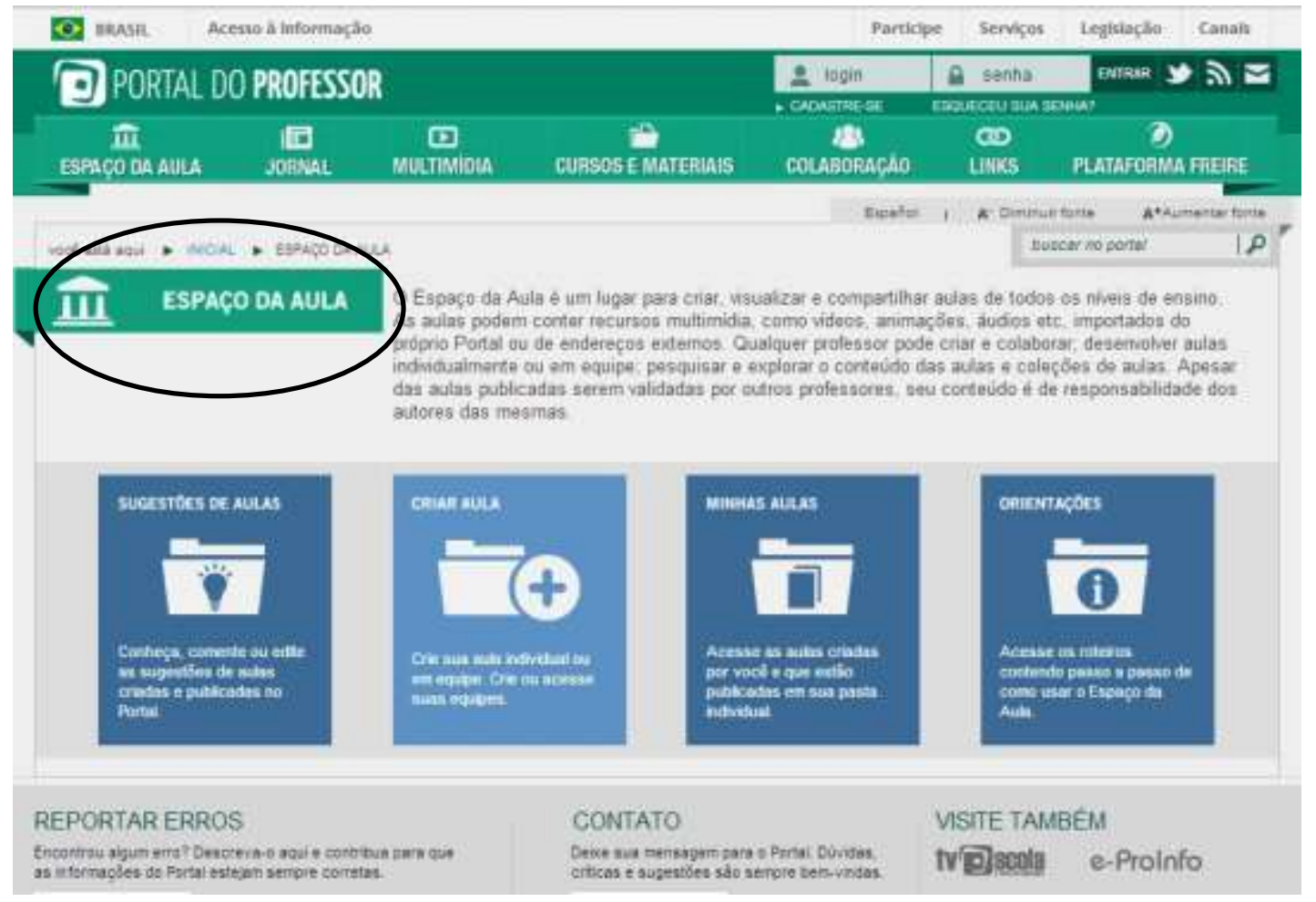

Figura 6 - Atual Pagina do "Espaço da Aula".

Fonte: Extraída de http://portaldoprofessor.mec.gov.br/index.html Acesso em: 14 Mar. de 2014

Ao acionar o elemento "Espaço da Aula" o usuário pode acionar o link "Sugestões da Aula" e suas opções “Aulas" e "Coleções de Aulas". Quando as duas páginas são acessadas, disponibilizam a opção de busca simples, por "palavra", em que o usuário digita uma palavra chave, como por exemplo "música". O Portal disponibiliza ainda a opção "mais opções de busca" com característica de busca avançada em que é possível especificar por meio de palavras-chave os termos de interesse de pesquisa.

A seguir, observamos na figura 7 a apresentação da página do "Espaço da Aula" na versão 1 que disponibiliza os elementos "Aulas" e "Coleções de Aulas: 


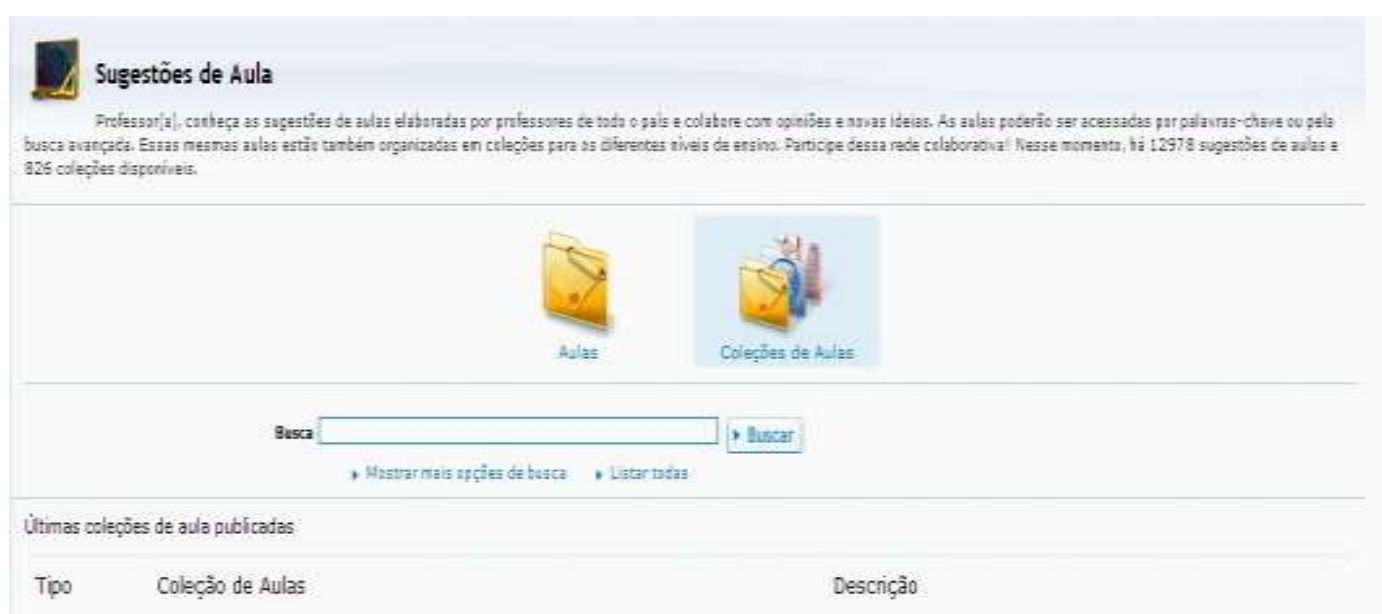

Figura 7 - Pagina de Sugestões de Aula.

Fonte: Extraída de http://portaldoprofessor.mec.gov.br/index.html Acesso em: 13 Mai. de 2013.

$\mathrm{Na}$ figura 8, observa-se o novo desenho da página, versão 2. Esse formato disponibiliza mais informações sobre a aba e opções de pesquisa.

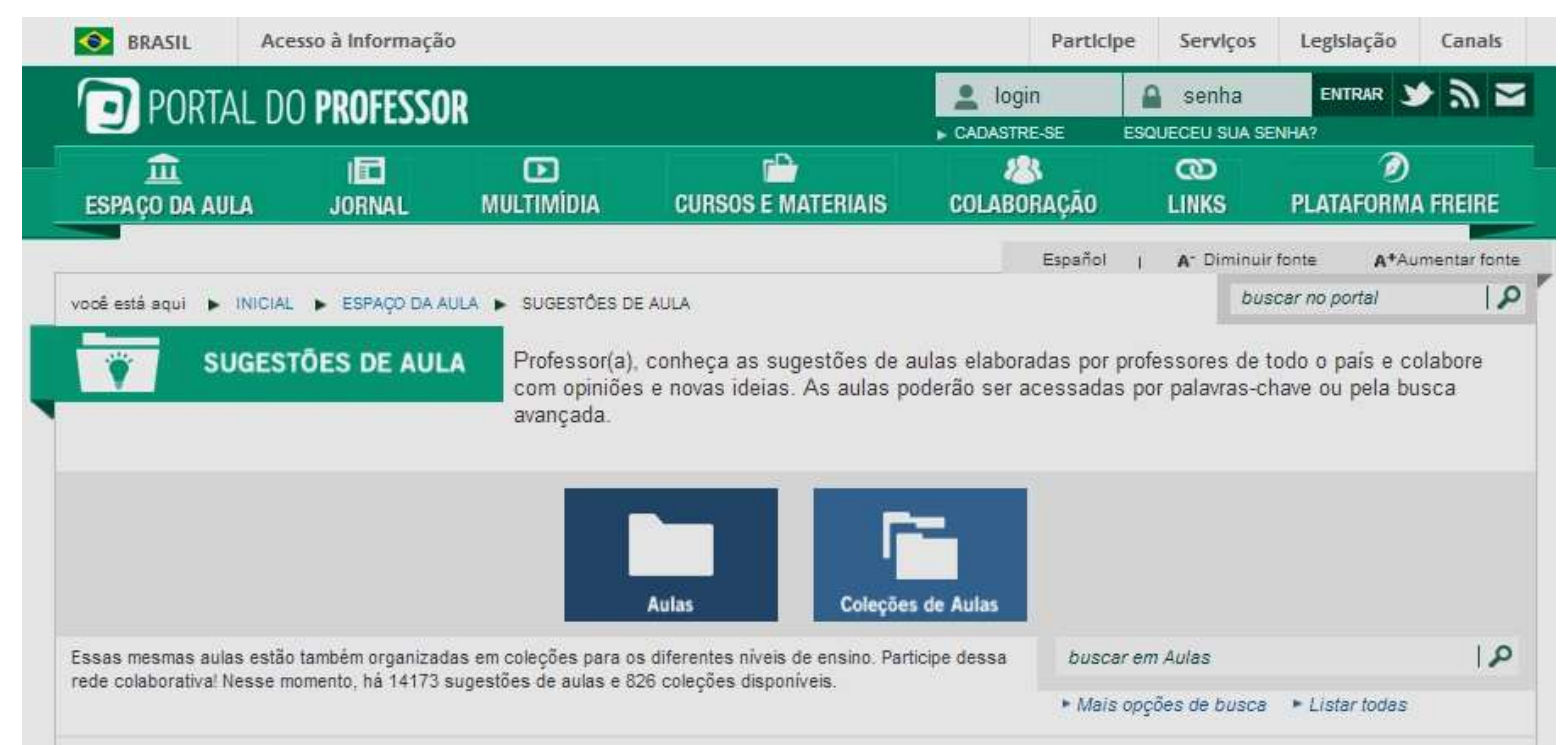

Figura 8 - Atual Pagina de Sugestões de Aula.

Fonte: Extraída de http://portaldoprofessor.mec.gov.br/index.html Acesso em: 13 Mar. de 2014.

A busca realizada no mês de setembro de 2013 no elemento "Aulas", utilizando a palavra-chave música, encontrou um total de $\mathbf{8 1 0}$ aulas e $\mathbf{9 3}$ coleções de aulas. Essas aulas são distribuídas nos diferentes níveis e modalidades educacionais da Educação Básica (Educação Infantil, Ensino Fundamental e Ensino Médio, Educação de Jovens e Adultos e Educação Indígena). 
Na busca avançada, "Opções de Busca", o usuário pode definir sua busca pelas categorias: 1) Tipo de Pesquisa, referindo-se ao nível ou modalidade de ensino; 2) Componente Curricular atendendo aos PCN; 3) Tema correspondendo à disciplina e as suas subdivisões segundo os PCN; 4) Unidade Federativa - UF e 5) Ordem de classificação, segundo critérios do Portal.

Quanto a Tipo de Pesquisa, a opção "Nível de Ensino" apresenta os níveis de Educação Infantil, Educação Profissional, Ensino Fundamental Inicial, Ensino Fundamental Final e Ensino Médio; e a opção "Modalidade" refere-se a Educação de Jovens e Adultos - $1^{\circ}$ Ciclo; Educação de Jovens e Adultos - $2^{\circ}$ Ciclo; e Educação Escolar Indígena. Os itens são apresentados em caixas de seleção para escolha do usuário.

A seguir, na figura 9, observa-se a opção "Mais opções de busca" na versão 1.

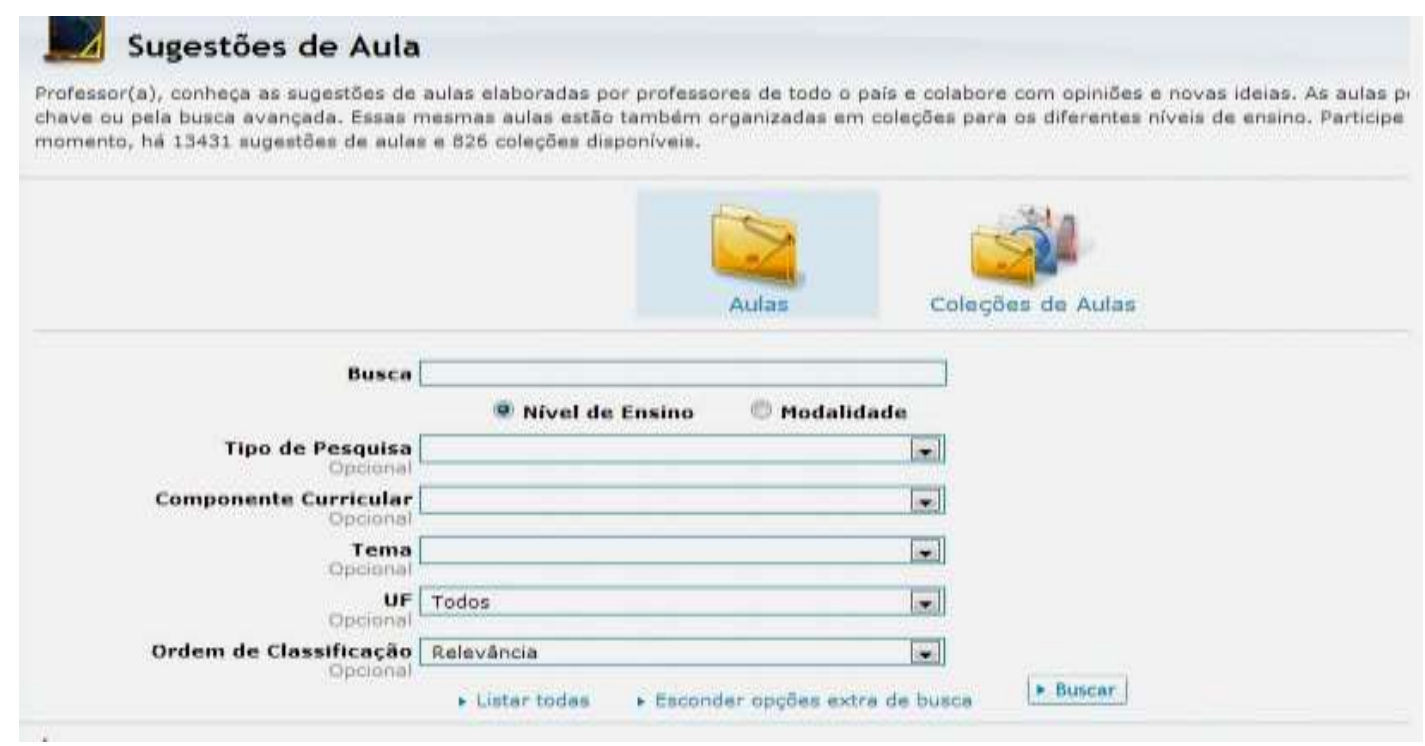

Figura 9 - Opções de Busca.

Fonte: Extraída de http://portaldoprofessor.mec.gov.br/index.html Acesso em: 14 Mai. de 2013.

A seguir, na figura 10, observa-se a opção "Mais opções de busca" na versão 2: 


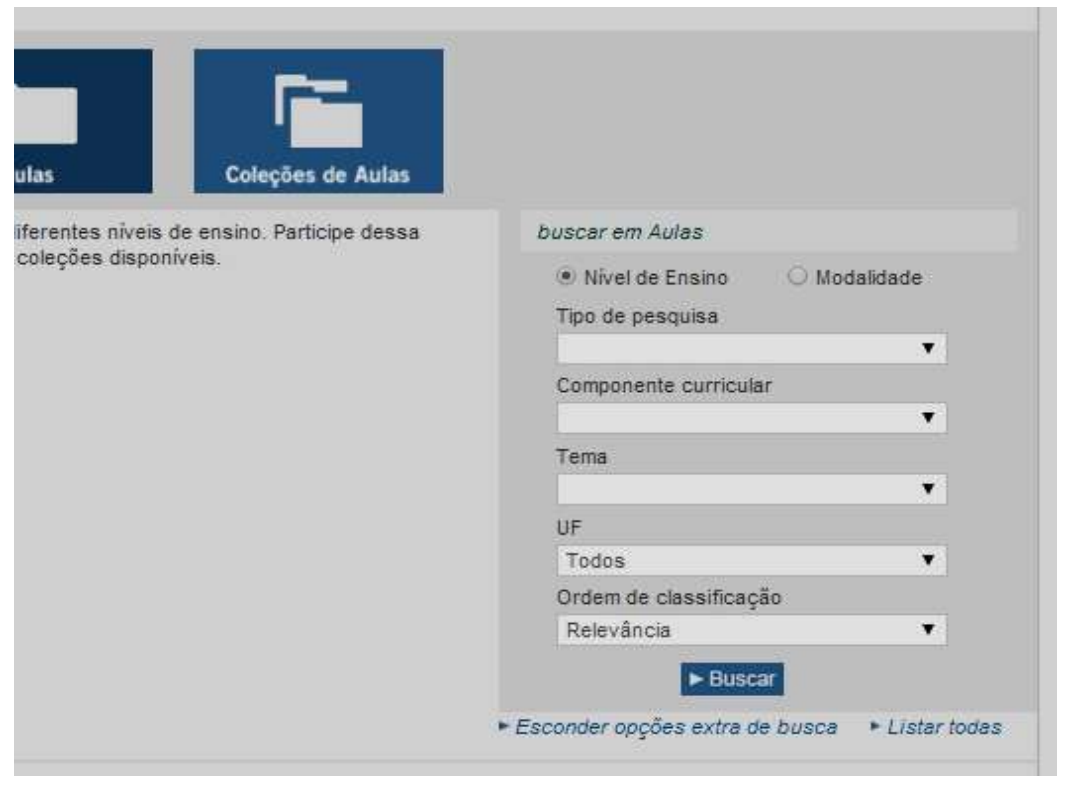

Figura 10 - Opções de Busca, apresentação atual

Fonte: Extraída de http://portaldoprofessor.mec.gov.br/index.html Acesso em: 13 Mar. de 2014.

O Portal apresenta parâmetros de organização do ensino por nível e modalidade que se diferenciam da estrutura apresentada pelos Parâmetros Curriculares Nacionais (PCN). O Portal não contempla, na opção Modalidade, a Educação a Distância, a Educação Especial e a Educação do Campo. Quanto a Educação Profissional e Tecnológica, o Portal a entende como Nível educacional e, não como Modalidade conforme é descriminado na Lei de Diretrizes e Bases da Educação Brasileira (LDB 9394/96) e nos PCNs. No quadro 1 a seguir é apresentado o Sistema da Educação Básica Brasileira. 
Quadro 1 - Sistema de Educação Básica

\begin{tabular}{|c|c|c|c|}
\hline \multicolumn{3}{|c|}{ ETAPAS DA EDUCAÇÃO BÁSICA (LDB, pp.69-71) ou Nível. } & $\begin{array}{c}\text { MODALIDADES DA } \\
\text { EDUCAÇÃ̃O BÁSICA (LDB, } \\
\text { pp.71-74) }\end{array}$ \\
\hline \multirow[t]{2}{*}{ Educação Infantil } & \multicolumn{2}{|c|}{$\begin{array}{l}\text { Creche, até } 3 \text { anos e } 11 \text { (onze) } \\
\text { meses. }\end{array}$} & $\begin{array}{l}\text { A cada etapa da Educação Básica } \\
\text { pode corresponder uma ou mais das }\end{array}$ \\
\hline & Pré-Escola, con & 2 anos. & modalidades de ensino: \\
\hline \multirow{9}{*}{ Ensino Fundamental } & \multirow[t]{5}{*}{ Inicial } & $1^{\circ}$ & Educação de Jovens e Adultos \\
\hline & & $2^{\circ}$ & \\
\hline & & $3^{\circ}$ & Educação Especial \\
\hline & & $4^{\circ}$ & \\
\hline & & $5^{\circ}$ & Educação Profissional e \\
\hline & \multirow{4}{*}{ Final } & $6^{\circ}$ & Tecnológica \\
\hline & & $7^{\circ}$ & Educação do Campo \\
\hline & & $8^{\circ}$ & \\
\hline & & $9^{\circ}$ & Educação Escolar Indígena \\
\hline \multirow[t]{2}{*}{ Ensino Médio } & \multirow[t]{2}{*}{3 anos } & $1^{\circ}$ & \\
\hline & & $2^{\circ}$ & Educação a Distância \\
\hline
\end{tabular}

Fonte: autor baseada na LDB, pp. 69-71.

No quadro 2 a seguir é apresentado o Sistema da Educação organizado nos níveis e modalidades segundo o Portal.

Quadro 2 - Organização da Educação Básica segundo Portal do Professor - MEC Parâmetros de organização dos níveis e modalidades da Educação Básica pelo Portal do Professor - MEC

\begin{tabular}{|c|c|}
\hline Níveis de Ensino & Modalidade \\
\hline Educação Infantil & Educação de Jovens e Adultos $-1^{\circ}$ Ciclo \\
Ensino Fundamental Inicial & Educação de Jovens e Adultos $-2^{\circ}$ Ciclo \\
Ensino Fundamental Final & Educação Escolar Indígena \\
Ensino Médio & \\
Educação Profissional & \\
\hline
\end{tabular}

Fonte: autor

O item "Componente curricular" identifica a área de conhecimento segundo a legislação brasileira. Para as aulas de música, o componente curricular é Artes nos diferentes Níveis de Ensino, exceto na opção Educação Profissional em que música está no componente curricular Produção Cultural e Design.

$\mathrm{Na}$ legislação educacional brasileira, especialmente, nas Diretrizes Curriculares Nacionais (DCN) para Educação Básica e nos PCNs a Arte é componente curricular da área de Linguagem e Códigos. No Portal do Professor, o item "Tema" para o Componente Curricular Arte se subdivide em temáticas específicas de acordo com o tipo de linguagem artística, música, teatro, artes visuais ou dança. No quadro 3 são apresentadas as opções de 
seleção de "Temas" disponibilizadas no Portal correspondente aos níveis educacionais Ensino Fundamental Inicial e Final, Ensino Médio e Educação Profissional. Cada “Tema” pode ser entendido como uma dimensão da linguagem artística a ser contemplada na formação do educando.

Quadro 3 - Temas da disciplina Música por Nível de Ensino segundo organização do Portal

\begin{tabular}{|c|c|c|c|c|c|c|}
\hline $\begin{array}{l}\text { NÍVEL DE } \\
\text { ENSINO }\end{array}$ & \multicolumn{6}{|c|}{ TEMA PARA CADA NÍVEL DE ENSINO } \\
\hline $\begin{array}{c}\text { Ensino } \\
\text { Fundamental } \\
\text { Final e Inicial }\end{array}$ & $\begin{array}{r}\text { Apreciação } \\
\text { em músi } \\
\text { envolvi } \\
\text { compre } \\
\text { linguager }\end{array}$ & $\begin{array}{l}\text { nificativa } \\
\text { escuta, } \\
\text { nto e } \\
\text { ão da } \\
\text { nusical. }\end{array}$ & $\begin{array}{r}\text { Compr } \\
\text { prod }\end{array}$ & $\begin{array}{l}\text { eensão da música como } \\
\text { uto cultural e histórico }\end{array}$ & $\begin{array}{l}\text { Express } \\
\text { em mús } \\
\text { composi }\end{array}$ & $\begin{array}{l}\text { comunicação } \\
\text { improvisação, } \\
\text { interpretação }\end{array}$ \\
\hline Ensino Médio & Canal & Contex & alização & $\begin{array}{l}\text { Estruturas } \\
\text { sintáticas }\end{array}$ & Estrutu & norfológicas \\
\hline $\begin{array}{c}\text { Educação } \\
\text { Profissional }\end{array}$ & $\begin{array}{c}\text { Técnico em } \\
\text { canto }\end{array}$ & $\begin{array}{r}\text { Técnico } \\
\text { Composi } \\
\text { Arranj }\end{array}$ & & $\begin{array}{l}\text { Técnico em } \\
\text { Documentação } \\
\text { Musical }\end{array}$ & $\begin{array}{l}\text { Técnico em } \\
\text { abricação de } \\
\text { nstrumentos } \\
\text { Musicais }\end{array}$ & $\begin{array}{c}\text { Técnico em } \\
\text { Instrumento } \\
\text { Musical }\end{array}$ \\
\hline
\end{tabular}

Fonte: autora

Especificamente, no Ensino Médio, as Orientações Curriculares para o Ensino Médio (OCNEM) entendem a Arte como componente curricular da área de Linguagens, Códigos e suas Tecnologias, o que abrange as linguagens artísticas música, teatro, dança e artes visuais (audiovisuais e midiáticas). Para o Ensino Médio, essa estrutura fundamenta-se nos elementos básicos dos processos da linguagem e da comunicação, em que o ensino e a aprendizagem são orientados pelos conceitos de código, canal e contexto conforme síntese apresentada no quadro 4.

O conceito de código está associado às estruturas morfológicas e sintáticas de cada linguagem. Na música, códigos são os elementos musicais e sonoros sua organização em estruturas musicais.

O canal corresponde ao meio utilizado para a comunicação, o que na música envolve diferentes e diversas fontes sonoras (corpo, voz, objetos sonoros e instrumentos musicais).

O contexto insere a linguagem na cultura e pode ser analisado a partir da experiência, da vivência e dos sentidos e significados que os sujeitos atribuem à linguagem. Na música envolve gêneros e estilos musicais, bem como as preferências e o gosto musical. A contextualização é um dos principais princípios pedagógicos das PCNs e é fundamental para a aprendizagem significativa. 
Quadro 4 - “Temas” segundo o OCNEM - MEC

\begin{tabular}{|l|l|l|}
\multicolumn{1}{|c|}{ CODIGO } & \multicolumn{1}{|c|}{ CANAL } & \multicolumn{1}{c|}{ CONTEXTO } \\
\hline $\begin{array}{l}\text { Estruturas morfológicas } \\
\text { Estruturas sintáticas }\end{array}$ & Diversas fontes & $\begin{array}{l}\text { Aluno, professor, escola, comunidade. } \\
\text { Ensino médio } \\
\text { Músicas }\end{array}$ \\
\hline
\end{tabular}

Fonte: autora baseada no OCNEM - MEC

Quanto às Modalidades Educação De Jovens e Adultos (EJA), $1^{\circ}$ e $2^{\circ}$ ciclo e Educação Escolar Indígena, no Portal, o componente curricular Arte não é definido. Ou seja não há opção de Componente Curricular Arte para o EJA $1^{\circ}$ ciclo e não há opção Arte Música para a Educação Escolar Indígena, embora esta apresente o Componente Curricular Arte. O quadro 5 apresenta a estrutura de seleção do Portal do Professor para as modalidades citadas

Quadro 4 - Componente Curricular Temas da disciplina Música por Modalidade de Ensino

\begin{tabular}{c|c}
\hline $\begin{array}{c}\text { MODALIDADE DE } \\
\text { ENSINO }\end{array}$ & Componente Curricular Arte e TEMA \\
\hline Educação de Jovens e & Música: desenvolvimento da linguagem musical \\
Adultos - EJA $-2^{\circ}$ ciclo & Não há Componente curricular Artes e nem Tema específico para música \\
\hline Educação de Jovens e \\
Adultos - EJA $-1^{\circ}$ ciclo \\
Educação Escolar \\
Indígena
\end{tabular}

Fonte: autor

O item de seleção "Unidade Federativa - UF" refere-se ao Estado que deve ser escolhido se o interesse da pesquisa for identificar aulas por estado específico.

O item "Ordem de classificação" refere-se aos critérios de organização e apresentação dos resultados de pesquisa de acordo com as buscas realizadas, as visitas e os títulos e assuntos das aulas disponibilizadas. O Portal oferece as seguintes opções: Relevância; Mais Acessadas; Mais Comentadas; Ordem alfabética; Ordem de publicação e Melhor Comentadas. O usuário tem a opção de filtrar sua pesquisa de acordo com esses critérios.

\subsubsection{As Pesquisas na temática Portal do Professor, Espaço da Aula, Música e Aula de Música}

Como descrito na Introdução desta Dissertação, foi realizado levantamento bibliográfico no Banco de Teses (BT) da Capes, abrangendo os anos de 2000 a 2014 na que 
foram utilizadas as palavras-chave "Música" e "Portal do Professor" como expressão exata. Nessa busca foram encontradas uma tese de doutorado e sete pesquisas de mestrado, das quais uma é de mestrado profissional e seis de mestrado acadêmico. Esses trabalhos todos relacionados com "Portal do Professor", mas nenhum deles relacionado a música.

A pesquisa de Doutorado foi desenvolvida na área da Educação em Ciências Química da Vida e Saúde por Sepel (2012). O trabalho consiste no estudo da associação entre atividades práticas e História da Ciência para o ensino de Ciências no Ensino Médio. Dentre a revisão de literatura sobre o tema, a autora analisa aulas práticas do Portal do Professor. Seu objetivo foi analisar "qual a contribuição do Portal do Professor para o incentivo de aulas práticas, através de sugestões de planejamentos e recursos, que fazem parte do acervo eletrônico" (SEPEL, 2012, p. 46). Os resultados da análise das aulas do Portal evidenciam uma grande repetição de uma mesma atividade prática em diferentes anos de escolaridade, o que sugere uma falta de inovação no processo de ensino e aprendizagem. A autora destaca ainda a baixa quantidade de experimentos nas aulas de Biologia e o predomínio de atividades práticas como "pano de fundo" dos conceitos teóricos.

Quanto às pesquisas de mestrado, foram produzidas cinco em 2011 e duas em 2012. Destes trabalhos, três são dissertações de mestrado acadêmico na área da Educação (ano 2011), três em Educação em Ciências e Matemática (anos 2011 e 2012) e uma em Comunicação Social (ano 2011). Esta última é uma dissertação desenvolvida por Habeyche (2011) que investigou weblogs disponibilizados na grande área "Interação e Colaboração" do Portal do Professor. A pesquisa objetivou "evidenciar as "marcas" que qualificam os posts como weblogs educacionais/profissionais, discutir se o weblog educacional/profissional é um canal de informação ou um canal de comunicação e relacionar as especificidades, no que se refere ao conhecimento científico ou senso comum nesses blogs" (HABEYCHE, 2011, p. 5). A pesquisa envolveu a análise dos blogs e questionário encaminhado para os blogueiros dos blogs analisados: Boteco Escola, Discurso Citado e Miriam Salles. A pesquisadora conclui que os blogs são espaços de produção de conhecimento e se caracterizam como uma canal de informação.

As pesquisas em Educação foram desenvolvidas por: Santos (2011), que discute um projeto de trabalho utilizando recursos do Portal do Professor para aprendizagem de conceitos matemáticos; Tinti (2011) que aborda o tema das práticas inclusivas nos planos de aula do Portal do Professor e Gense (2011) que aborda a inclusão digital e o ensino de língua inglesa. Dentre as dissertações em Educação em Ciência e Matemática e Educação Matemática e 
Tecnológica: Freitas (2011) analisou a organização das aulas de Biologia publicadas no Espaço da Aula do Portal; Carmo (2012) discute o planejamento da aula e a inclusão digital e Lehner (2012) em Mestrado profissional, apresenta trabalho que consiste na elaboração de um tutorial para o uso de Objetos de Aprendizagem com tema genética.

No repositório da Biblioteca Digital Brasileira de Teses e Dissertações (BDTD) do Instituto Brasileiro de Informação em Ciência e Tecnologia (IBICT) foi realizado levantamento bibliográfico abrangendo os anos de 2000 a 2014 e as mesmas palavras-chave "Música" e "Portal do Professor" utilizadas no levantamento bibliográfico realizado no Banco de Teses (BT) da Capes. Nessa busca, foram encontradas a mesma tese de doutorado de Sepel (2012) e duas das sete dissertações de mestrado encontradas no BT da CAPES. Contudo, a busca indicou duas dissertações de mestrado não citadas no portal da CAPES: a de Bataliotti (2014), em Educação Especial, sobre a aplicabilidade dos planos de aula de Educação Física do Portal na prática inclusiva e a de Zacharias (2013), em Linguística Aplicada, na que identifica propostas de introdução das tecnologias no letramento do Ensino Fundamental.

Dentre as dissertações encontradas, o trabalho de pesquisa realizado por Freitas (2011) se aproxima deste estudo. A autora visou compreender a organização das aulas de Biologia publicadas no Portal do Professor e a sua relação com as políticas públicas para a disciplina Biologia. Quanto à organização das aulas no Portal, a Freitas (2011) comparou a proposta e orientação de planejamento do Portal com a estrutura e organização que os professores dão à suas aulas no "Espaço da Aula". A pesquisa adotou uma abordagem qualitativa com análise documental. A autora analisou os documentos oficiais que orientam a proposta pedagógica e curricular para o Ensino Médio e o Ensino de Biologia no Brasil (PCNEM, PCN+ e OCNEM), bem como 10 aulas de Biologia publicadas no Portal, observando seus componentes, suas relações com a proposta do Portal e com as políticas públicas. Paralelamente, a autora analisou 72 aulas de biologia quanto aos aspectos de número de acessos e local ou região de vinculação dos autores das aulas publicadas.

Os resultados indicam que: os planejamentos são voltados para ações do tipo cognitivo; há distanciamento entre as aulas publicadas e as propostas das políticas públicas; há fragmentação ou desconexão entre os componentes das aulas disponibilizadas, inviabilizando a unidade da aula; há desconhecimento das possibilidades do uso das NTICs para atividades de colaboração e de interação e há desconhecimento das possibilidades de recursos disponibilizados no Portal. Contudo, Freitas (2011) aponta como contribuição do 
Portal o resgate do conceito de Planejamento e sua importância na atividade docente como elemento de orientação para o professor. 


\section{A AULA: PLANEJAMENTO E PRÁTICA}

Neste capítulo, são apresentados os conceitos de aula e de planejamento e como essas concepções são abordadas por alguns autores da Educação Musical. Discutir esses conceitos orientará a interpretação das análises das aulas de música do Portal do Professor.

A aula, nas palavras de Veiga (2008) é o "lugar privilegiado da vida pedagógica, refere-se às dimensões do processo didático - ensinar, aprender, pesquisar e avaliar -, preparado e organizado pelo professor e seus alunos.” (VEIGA, 2008, p.267). Quanto à organização da aula a autora destaca três aspectos que ela considera especialmente significativos: 1) a relação professor-aluno e o aluno como princípio e fim; 2) a dimensão socializadora da aula e 3) as condições enfrentadas pelo professor referentes aos materiais, ao número de alunos, às características dos alunos e ao tempo da aula.

Neste trabalho de pesquisa, a aula é pensada como a representação da "gestão do conteúdo" refletida no planejamento. O planejamento indica aonde ir, por que e como ir.

O termo "gestão de conteúdo" é aqui entendido como "arranjo estrutural da aula" (ARAUJO, 2008, p. 47), composto pelo conteúdo, a metodologia e a avaliação. O conteúdo inclui as finalidades e os objetivos; a metodologia inclui os métodos, as técnicas e as tecnologias, por fim, a avaliação refere-se a correspondência das intenções, necessidades e resultados esperados que foram traçados num começo. Para Araújo (2008), esses elementos devem ter um tratamento que os integre e os conecte de forma organizada, como descrito a seguir pelo próprio autor:

Esses aspectos constituem o arranjo estrutural da aula, o que propicia afirmar que o dar aula envolve sistematização, organização, ordenação, coerência, metodização, coesão, logicidade, racionalidade, entrelaçamento - certamente do conteúdo, da metodologia, da avaliacäo feita, bem como dos objetivos e das finalidades esperados e concretizados. Tais substantivos em itálico, que expressam uma rede sinonímica plural entre eles, traduzem, nada mais nada menos, que harmonia, conexão, vínculo, união e nexo entre os aspectos que envolvem o arranjo estrutural da aula. (ARAUJO, 2008, p. 47).

O planejamento é a gestão do desenvolvimento e aplicação do currículo na aula, o planejamento da aula é a evidencia textual dessa gestão, como se observa nas seguintes palavras: “[...] é a realização formal dum conjunto de conteúdos e atividades pensadas para se 
trabalhar num contexto e num futuro mais ou menos próximo"16 (IMBERNÓN, 2008, p.107, tradução da autora).

O planejamento serve como apoio sobre a previsão de uma ação que envolve o ambiente todo, como descrito nas palavras de Sacristán (2000):

A utilidade do plano está em nos ajudar a dispor de um esquema que represente um modelo de como pode funcionar a realidade antes de ser uma previsão precisa dos passos a serem dados. Se o currículo deve observar a experiência do aluno/a, o plano é antes de mais nada, a prefiguração de um ambiente global, pensando não apenas na ordem que o ensino deve seguir ou na sequência dos conteúdos, mas no curso da experiência de aprendizagem. (SACRISTÁN, 2000, p. 203).

Planejar segundo Sacristán (2000) é a atividade de dar forma ao currículo e adequa-lo às especificidades dos níveis educacionais, uma atividade entre o conhecer e o atuar. Planejar é representar um guia de desenvolvimento do próprio currículo. Esse definido pelo autor como: "complexa trama de experiências que o aluno/a obtém, incluídos os efeitos do currículo oculto" (SACRISTÁN, 2000, p. 202). Para esse autor, planejar implica: prever a ação, referindo-se à prática antes de realizá-la.

Para Sacristán (2000), o professor definido como planejador é quem interpreta e adequa o currículo ao contexto da sua prática. $\mathrm{O}$ autor define a profissão de planejador na seguinte citação:

O planejador é, para Schön (1983 e 1987), alguém que dialoga com a situação em que atua, que reflete sobre uma prática, que experimenta com uma ideia guiado por princípios, que configura um problema, distingue seus elementos, elabora estratégias de ação ou configura modelos sobre os fenômenos, tendo uma representação implícita de como estes se desenvolvem. (SACRISTÁN, 2000, p. 198).

Experiências anteriores próprias ou de outros podem ser aproveitadas em novas situações, razão porque Sacristán (2000) considera os planejamentos como um acervo aproveitável.

Para Imbernón (2008) planejar ou programar é preparar previamente atividades, isto inclui conhecer com antecedência a situação, o conhecimento do presente e a projeção futura. A gestão de conteúdo ou planejamento da aula baseia-se na necessidade de saber com antecedência: para que serve; de onde parte; o que fazer; onde; e como fazer.

\footnotetext{
16 “...es la plasmación formal de un conjunto de contenidos y actividades pensadas para que sean trabajadas en un contexto y en un futuro más o menos próximo.” (IMBERNÓN, 2008, p.107).
} 
Planejar uma aula permite organizar as ideias do professor adaptando-se ao contexto, para Imbernón (2008), planejar oferece segurança e elimina no sentido negativo a improvisação e o acaso, elimina programas incompletos dando reflexão sobre sequência e temporização, evita perda de tempo e esforço desperdiçado, sistematiza, ordena e conclui um projeto conjunto de professores e permite adaptação do trabalho pedagógico às caraterísticas culturais e ambientais do contexto.

A apresentação do planejamento na cultura ocidental, tem sofrido modificações marcadas pelo contexto histórico. Seguindo a descrição realizada por Imbernon (2008), até antes da II Guerra Mundial, o professor planejava escrevendo notas em que constava o que ensinar e como ensinar. Após este período, surge um estilo de ensino programado: taxonomias, objetivos operacionais, conceitos de eficácia e comprobação de resultados mensuráveis da conduta, que aparecem como consequências educacionais da psicologia condutista, o que segundo o autor, lhe dá o caráter de planejamento tecnológico.

Posteriormente, na década de 1950, a teoria educativa influenciada por conceitos positivistas da ciência, propõe novas formas de organização da experiência da aprendizagem, arredor de objetivos operativos e específicos. Imbernón (2008) realiza uma crítica a este tipo de planejamento ativista, por considerá-lo claramente irreflexivo e distanciado da prática, reduzido a soma de atividades.

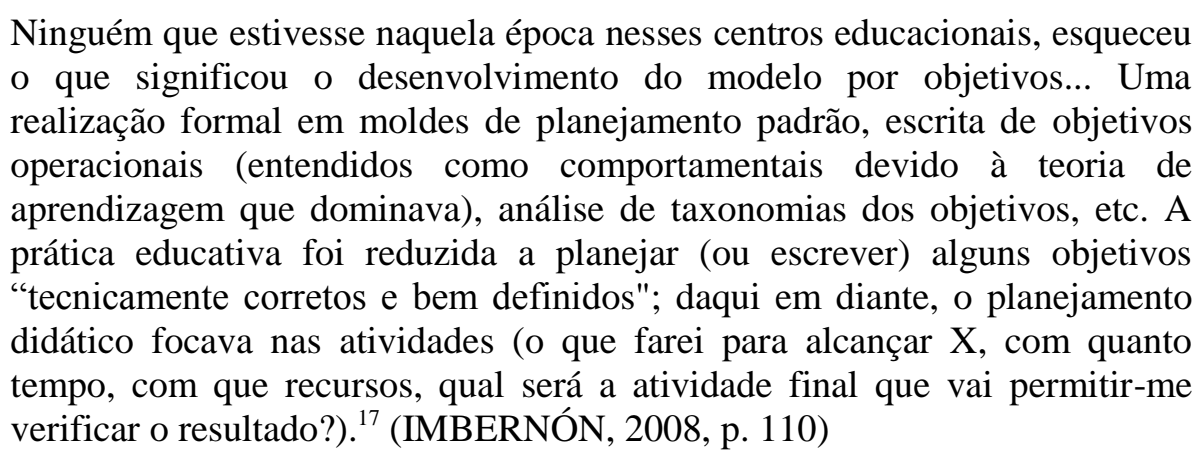

Essa forma de se pensar o planejamento, segundo o mesmo autor, distancia a teoria da prática reduzindo-se ao preenchimento de um formato em colunas classificando: objetivos, conteúdos, atividades, recursos, tempo e avaliação. Esse tipo de plano foi realizado como um

\footnotetext{
${ }^{17}$ Nadie que en ese momento estuviera en los centros educativos ha olvidado lo que comporto el desarrollo del modelo por objetivos... Una plasmación formal en plantillas de programación estándar, redacción de objetivos operativos (entendidos como conductuales debido a la teoría del aprendizaje predominante), análisis de taxonomías de objetivos, etc. La práctica educativa se reducía a planificar (o redactar) unos "técnicamente correctos y bien definidos" objetivos; a partir de aquí, la programación didáctica se centraba en las actividades (¿Qué haré para alcanzar X, en qué tiempo, con qué recursos, cuál será la actividad terminal que me permitirá comprobar el resultado?). (IMBERNÓN, 2008, p. 110)
} 
planejamento por mês, por quinzena ou diário, se reduzindo a tarefa de se pensar sempre a verbos a usar e como relatá-los. Segundo o autor, esse tipo de planejamento resulta numa imagem enganosa da modernidade, da eficácia e da cientificidade.

Com a introdução do chamado cognitivismo, no final da década de 1980, o planejamento passa a ser pensado segundo o aluno e o contexto. Passar-se-á pensar nos processos, ambiente, diversidade e ferramentas. O planejamento visa aumentar a qualidade do trabalho e é considerado necessário para sistematizar o processo de ensino-aprendizagem.

\subsection{COMPONENTES: NOVO MODELO}

No novo modelo de planejamento com a influência do cognitivismo, surgem novos elementos que informam sobre: os conhecimentos; a organização de conteúdo; a forma de trabalho e a regulação de avaliação e retroalimentação. Estes fazem referência a tudo o que intervém no processo do ensino. Imbernón (2008) define esses elementos com os seguintes critérios:

O elemento conhecimentos, refere-se ao contexto do ensino. O conhecimento a ser tratado e a seleção cultural. Permite analisar o conteúdo de aprendizagem como experiências socioculturalmente organizadas, assim como os objetivos ou processos de crescimento pessoal que desejem criar, incentivar ou facilitar, através da educação. A organização inclui o conteúdo e o ambiente no que se organiza e realiza a aprendizagem. A Forma refere-se ao como devem-se estruturar as experiências de aprendizagem e os interesses dos alunos. Na prática é estabelecer tarefas, recursos e processos de temporização intimamente relacionadas. A regulação acontece durante o processo todo, com referência as etapas de avaliação e retroalimentação do processo e do resultado do ensino-aprendizagem. ${ }^{18}$ (IMBERNÓN, 2008, p.116).

Não há um acordo sobre os modelos e nem sobre os componentes de um planejamento, Araujo (2008) descreve os componentes como partes do planejamento, sendo

\footnotetext{
${ }^{18}$.Qué conocimientos que hay que tratar y su selección cultural. Permite analizar los contenidos de aprendizaje, como experiencias socioculturalmente organizadas, y los objetivos o procesos de crecimiento personal que se deseen suscitar, favorecer o facilitar mediante la enseñanza. Es el contexto de la enseñanza.

.Cómo organizar el contenido y en qué escenario o ambiente (organización del aprendizaje) se realiza el aprendizaje.

.De qué forma trabajar el contenido en la acción. Esto es, cómo hay que estructurar las experiencias de aprendizaje y los intereses de los alumnos. En la práctica, lleva al establecimiento de tareas, recursos y procesos de temporización íntimamente relacionadas. (IMBERNÓN, 2008, p.116).

.Cómo regular todo el proceso, con referência a las fases de valoración y realimentación del proceso y del resultado de enseñanza-aprendizaje. (IMBERNÓN, 2008, p.116).
} 
eles, um tipo de explicação ou um sinal que deve dar a entender o conteúdo, as finalidades, os objetivos, a técnica, a tecnologia e a avaliação. Para o autor, essas partes, são um símbolo da “escolarização como elemento civilizatório". Sendo as partes uma dimensão externa da aula, elas levam no seu interior a cultura. Num planejamento de aula, pode-se observar a realidade cultural como ela é vivida e como ela é pensada.

Veiga (2008) descreve os componentes em substantivos descritos como indagações que respondem a toda organização, são eles: Para quê? O quê? Como? Com quê? Como avaliar? Para quem? Quem? Quando? Onde? Os qualificativos para cada uma das questões correspondem a: Para quem? Aluno; Quem? Professor; Quando? Tempo; Onde? Espaço; Para quê? Intenção; O quê? Conteúdo cultural; Como? Metodologia; Com quê? Recursos didáticos e O quê? Como? Quem? Avaliação.

Sacristán (2000) esclarece que não há um modelo de planejamento único portanto todo planejamento depende da situação, do contexto, da escola, da área curricular ou da unidade de conteúdo. Porém, baseado em Eisner (1979), ele descreve os componentes como dimensões que não precisam ser seguidas numa sequência especial: finalidades; conteúdos; atividades. Estas são o elemento provocador dos processos de aprendizagem, de organização de conteúdo, das formas de resposta e da avaliação.

O Portal do Professor na página "Reflexões Pedagógicas", link da página "Orientações", destaca a importância do professor na gestão da aula, enfatizando o seu papel na decisão da seleção e organização de objetivos, estratégias e recursos de aprendizagem.

Os componentes de aula apresentados na versão 2 do Portal e descritos no tutorial “Como criar uma aula?" do elemento "Orientações" da grande área do "Espaço da Aula" são: 1) O que o aluno poderá aprender com esta aula; 2) Duração das atividades; 3) Conhecimentos prévios; 4) Estratégias e recursos da aula; 5) Recursos Complementares; 6) Avaliação.

"O que o aluno poderá aprender com esta aula", refere-se ao que se espera que o aluno aprenda, ao objetivo e finalidades da aula, que pressupõe clareza de conteúdos, conhecimentos e competências. A "Duração das atividades" refere-se ao tempo das atividades ou de desenvolvimento do projeto proposto, o que pode ocorrer em uma aula ou em um número estimado de aulas. O componente "Conhecimentos prévios" refere-se ao nível de desenvolvimento do grupo, a faixa etária e as experiências já vividas, pressupõe conhecer quem é o aluno, como também, os conhecimentos prévios necessários para o desenvolvimento da aula proposta. Nas "Estratégias e recursos da aula" encontram-se a sequência e 
desenvolvimento de atividades, as estratégias, as técnicas e os recursos propostos para o aluno atingir os objetivos e o professor ativar o processo de ensino e aprendizagem; pressupõe o como e o com o quê. Os "Recursos Complementares" indicam outras fontes de informação ou de recursos para a aula. Finalmente a "Avaliação" é entendida como a atividade que analisa as competências e habilidades desenvolvidas, os objetivos alcançados, bem como a auto avaliação do professor, o que pressupõe observar o quê, para quê, como e quem.

Imbernón (2008) descreve os componentes da estrutura organizativa da aula atentando para a relativa ênfase a um ou outro componente segundo o interesse do professor: objetivos; conteúdos; estratégias metodológicas ou atividades; recursos; momentos de avaliação; dinâmicas de grupo.

O Portal apresenta esses mesmos componentes, porém, utiliza uma terminologia diferenciada, como é o caso dos objetivos, associados à frase: “O que o aluno poderá aprender com esta aula"? Nas orientações para as aulas, o Portal também apresenta um item específico para conteúdo, mas esse é identificado nas atividades, recursos e dinâmicas de grupo apresentadas no item "Estratégias e recursos da aula".

A seguir são detalhados componentes do planejamento a partir de Imbernón (2008).

\subsubsection{Objetivos}

Diz respeito ao momento para estabelecer e interpretar o que há de se alcançar ao longo do processo de ensino-aprendizagem. Imbernón (2008) afirma que na própria ação pedagógica aparecem novos objetivos. Esses são o guia do planejamento e não o eixo, eles não se identificam com o objetivo-resultado da aprendizagem. A natureza deles depende do enfoque psicológico que os orienta. São objetivos de capacidade, de tendência, de expressão, e fazem referência às capacidades que se pretendem desenvolver nos alunos. Essas capacidades podem ser cognitivas, motoras, de relação interpessoal, de equilíbrio pessoal, de atuação e de integração social. Os objetivos subministram informações das propostas.

Veiga (2008) descreve quatro dimensões para definir o componente referente à intenção e objetivos: 1) finalidades de natureza filosófica e política; 2) gestão educativa; 3) pedagógica e 4) prática pedagógica. As finalidades de natureza filosófica e política expressam a intencionalidade educativa e que no caso para o Brasil, estão descritas na LDB: "pleno desenvolvimento do educando", "preparo para a cidadania" e "qualificação para o trabalho" 
(LDB, 9.394, art.2, p. 276). Quanto a Gestão educativa, a autora a descreve como a dimensão que depende do projeto de cada instituição. A dimensão Pedagógica refere-se às intenções e aos objetivos gerais e específicos explicitados nas disciplinas. Ela tem a função de orientar e guiar o processo didático e de clarificar os propósitos e as intenções educativas. Por fim, a dimensão Prática Pedagógica explicita o tipo de capacidade esperada dos alunos que se adequa às suas possibilidades e seus interesses.

O Portal, como dito, inclui os objetivos na frase "O que o aluno poderá aprender com esta aula" e recomenda o desenvolvimento de habilidades cognitivas expressas em verbos. Ele define os objetivos centrados no aluno e com estreita relação com a avaliação, como observado em "Dicas para elaboração de aulas", link da página "Orientações” da grande área "Espaço da Aula":

Objetivos: O que o aluno poderá aprender com esta aula? Responda de forma simples e objetiva para que as competências elencadas (ou mencionadas) representem resposta à pergunta inicial: O QUE O ALUNO PODERÁ APRENDER COM ESTA AULA? (PORTAL DO PROFESSOR, acesso em 14 abril de 2014, p. 5).

A utilização de verbos de ação para se referir aos objetivos considera-se útil pelo Portal. Este recomenda que o autor da aula expresse os objetivos em verbos de ação em infinitivo ("Reflexões Pedagógicas", p.2) e sugere que eles sejam precisos e claros para, assim, serem passiveis de avaliação.

\subsubsection{Conteúdos}

Segundo Imbernón (2008) os conteúdos são o "conjunto de formas culturais e saberes que constituem parte das relações sociais do contexto, introduzindo-se e permitindo organizar as tarefas pedagógicas da aula para construir e reconstruir o conhecimento do aluno" (IMBERNÓN, 2008, p.118). O conteúdo de aprendizagem de uma disciplina está constituído pelas contribuições culturais e cientificas relativa ao seu objeto. A sua seleção, organização e adaptação podem contribuir à aprendizagem significativa pretendida.

Uma referência para elaborar os conteúdos no planejamento baseia-se nos tipos de conteúdo: conceituais; procedimentais; e atitudinais (MERRIL apud IMBERNÓN, 2008). O conteúdo conceitual na aula pode se dividir em dois blocos diferentes: conceitos e sistemas conceituais; e fatos. Os fatos caracterizam atividades mais repetitivas e de memorização. Os 
conceitos e sistemas conceituais envolvem compreensão da ação, estruturadas no contexto e na ação. O conteúdo procedimental inclui habilidades, competências, estratégias. O conteúdo atitudinal inclui comportamentos, valores e normas.

No Portal do Professor, nos planejamentos da aula de música, o componente conteúdo pode ser observado em diferentes espaços dedicados aos objetivos ou às atividades, como em: "O que o aluno poderá aprender com esta aula?" e "Estratégias e recursos da aula". Também em certas aulas, observa-se o conteúdo como nota explicativa. Contudo, no Portal, os autores para expressarem, no título, o conteúdo, este "precisa ser objetivo, claro e relacionado diretamente com o conteúdo ou com o tema trabalhado" (PORTAL DO PROFESSOR, "Dicas para elaboração de aulas”, p. 2).

Para Veiga (2008) o conteúdo é o "elemento chave para concretizar as intenções educativas" (VEIGA, 2008, p. 277). Ele é considerado o elemento que se adequa às necessidades educativas e culturais e às capacidades cognitivas, afetivas, psicomotoras e sociais do aluno. A autora esclarece, ainda, que os conteúdos representam o meio para o desenvolvimento das capacidades e não um fim. A organização da aula gira em torno do tipo de conteúdo cultural e se adequa a esse pelos objetivos, pelos métodos e pelas técnicas. $\mathrm{O}$ conteúdo cultural, parafraseando a autora, contém algumas características: seleção de saberes culturais de uma sociedade; saberes historicamente construídos que incluem entre outros, núcleos temáticos, disciplinas, blocos ou eixos; adequação às necessidades educativas e culturais e às características dos alunos. Eles são meios para desenvolver capacidades, mas não fim em si mesmos. (VEIGA, 2008, p. 277-278).

Veiga (2008) citando Ortega e Mata descreve três tipos de conteúdo: científico; psicológico e social. O científico refere-se aos aspectos da aprendizagem de validade, coerência e significado. O psicológico refere-se aos aspectos de potencialidade e adequação do que se dispõe. O social refere-se à contextualização, a sua funcionalidade e possibilidades.

O conteúdo é, pois, entendido pelos autores apresentados como elemento ou meio para o desenvolvimento das aprendizagens e, nesse sentido, orienta objetivos e atividades. Contudo, é importante que o professor o relacione com os conhecimentos prévios do aluno e com o seu contexto sociocultural. Outro aspecto a destacar são os tipos e modalidades de conteúdos. Eles podem estar associados a fatos, ações e objetivos de natureza distinta: cognitiva/científica, procedimental/psicológica e atitudinal/social. 


\subsubsection{Método e Atividades}

Para Imbernón (2008), o método deve ser adequado pelo docente, respondendo ao modelo ou tendência de uma corrente filosófica ou psicopedagógica ou à sua própria concepção. $\mathrm{Na}$ metodologia inter-relacionam-se todos os elementos do planejamento (objetivos, conteúdos, atividades e recursos). O método pressupõe uma sequência que comumente se organiza do mais simples ao mais complexo. Essas sequências podem ser de resultado ou sequência do processo. Na primeira, predomina a memorização e o acúmulo de conhecimentos; na segunda, as tarefas por descobrimento, os alunos estão em atitude ativa, e nela, os conhecimentos prévios servem para os próximos, em forma cíclica.

O componente Método é descrito pelo autor como Estratégia metodológica ou atividades, por ter implícito um conjunto de elementos: para cada atividade existe um objetivo e um conteúdo a desenvolver por meio de uma estratégia, onde há também um material, um tempo e um espaço. Por esta razão, Imbernón (2008) afirma que o eixo do planejamento são as atividades e não os objetivos.

As atividades devem ser pensadas para cada momento em que serão usadas: na introdução como motivação; nos conhecimentos prévios; no desenvolvimento e compreensão dos conteúdos; na consolidação; no reforço; na recuperação; na opinião e na expansão. No planejamento das atividades deve se levar em conta várias condições: tempo; lugar-espaço; organização; materiais.

Para Veiga (2008), o método deve atender ao objetivo, ao conteúdo e ao aluno. O método deve incluir três aspectos: psicológico; lógica; educativo. O aspecto psicológico refere-se à adequação ao sujeito que aprende. O aspecto da lógica refere-se à adequação ao conteúdo. $\mathrm{O}$ aspecto educativo refere-se à criação de hábitos de ordenação, de organização e de abstração.

A autora considera que "todo método propicia atividades para o professor e outras, distintas, para os alunos" (VEIGA, 2008, p. 282). Veiga (2008) considera três enfoques metodológicos: globalização; individualização e socialização. Qualquer que seja o enfoque, esse será desenvolvido por meio de técnicas que Titone (1981) considera estarem centradas: no professor, se for, por exemplo, um estudo dirigido ou estudo de texto ou na individualização, se for, por exemplo, um ensino programado ou na socialização, se for, por exemplo, uma discussão, um trabalho em grupo ou um estudo do meio. 
No planejamento do Portal do Professor, em "Estratégias e recursos da aula", encontram-se conteúdos e estratégias metodológicas ou atividades. O Portal sugere que o professor, ao planejar a aula, selecione os conteúdos para contribuir ao desenvolvimento dos alunos nos aspectos conceitual, procedimental e atitudinal, como observado a seguir:

Privilegie estratégias em que os alunos sejam os atores principais, propondo pesquisas e debates, para que ocorra construção, colaboração entre colegas, registros e divulgação dos novos conhecimentos. Proponha atividades que possam contribuir com o desenvolvimento dos alunos nos diversos aspectos: conceituais, procedimentais e atitudinais. Procure ("Reflexões Pedagógicas" Portal do Professor, acesso em 14 Ab. de 2014, p. 3).

No espaço reservado à criação de aulas, "Estratégias e recursos da aula", o Portal fornece instruções e parâmetros de avaliação da metodologia da aula para que o usuário possa planejar sua aula e suas atividades, como observado na seguinte citação:

As estratégias representam o roteiro de trabalho. Neste campo você deverá escrever as orientações para o trabalho dos alunos. Ao apresentar as estratégias para sua aula pense na sequência didática: se as atividades estão ordenadas, estruturadas, ligadas entre si, planejadas para ensinar um conteúdo, etapa por etapa, organizadas de acordo com os objetivos que o professor listou no primeiro campo. (PORTAL DO PROFESSOR, "Dicas para elaboração de aulas", acesso em 14 abril de 2014, p. 4).

Apresentam-se também nesse espaço, além das atividades, os recursos que o professor usará para o desenvolvimento das mesmas.

\subsubsection{Recursos}

Veiga (2008), tendo por referência Rivilla e Mata (VEIGA, 2008, p. 284), classifica os recursos pedagógicos em três possibilidades: objetos materiais; meios e equipamentos escolares; e meios simbólicos. Os objetos materiais servem à experiência direta do aluno enquanto os meios e equipamentos escolares diversos incluem lugares como biblioteca e laboratório. O material impresso e as novas tecnologias são entendidos como meios simbólicos. Veiga destaca a importância das tecnologias educativas como uma "valorização de experiências inovadoras". (VEIGA, 2008, p. 285). 
Para o Portal do Professor, os recursos são um apoio didático para um melhor ensino e integram estratégias, equipamentos e dinâmicas de grupo. O Portal exige que os autores incluam recursos multimídia no planejamento de suas aulas e apresenta a seguinte orientação:

Não confundir recursos com materiais. Os materiais podem ser: tesoura, cartolina, cola, computador, etc. Recursos são ferramentas didáticas que ajudam o professor a ensinar melhor, que enriquecem o planejamento de uma aula ou atividade. São recursos portanto: as estratégias de leitura, de socialização do resultado de uma pesquisa ou de um trabalho de grupo, uso de áudios, ou vídeos, jogos (incluindo os virtuais), simulações, mediante uma determinada dinâmica etc., jornais, livros, revistas, CDs, CD-ROM, sites etc, podem fazer parte de um e de outro, dependendo do enfoque. (PORTAL DO PROFESSOR, "Dicas para elaboração de aulas", acesso em 14 Ab. de 2014, p. 6).

Nos "Recursos Complementares", em item a parte, o Portal fornece aos autores um espaço especial para listar materiais e fontes que complementem as atividades.

\subsubsection{Avaliação}

O componente da avaliação refere-se ao instrumento e critério de análise, reflexão e continuidade do processo de ensino-aprendizagem (IMBERNÓN, 2008; VEIGA, 2008), não como um sistema de mensuração ou de classificação na escala do êxito dos alunos, mas como um meio de reflexão e continuidade.

A avaliação como medição dos resultados e efetividade dos objetivos e a avaliação numa perspectiva atual que entende e valoriza os processos e resultados das tarefas educacionais no seu contexto, cuja finalidade é melhorar a intervenção pedagógica, controlando e adaptando o planejamento aos alunos, comprovando a utilidade da intervenção pedagógica.

A avaliação pode usar diversas ferramentas ou instrumentos. Na avaliação de processos usam-se, entre outros, a observação, a entrevista, os registros e os questionários. A finalidade da avaliação segundo Ibernón (2008) está em melhorar os processos de intervenção educativa, como observado nas palavras do próprio autor:

A finalidade da avaliação é de melhorar as tarefas de intervenção educativa, controlando todos os elementos que intervém no planejamento, para se adaptar a cada vez mais aos alunos, e verificar se essas intervenções 
educativas foram ou não uteis. ${ }^{19}$ (IMBERNÓN, 2008, p. 131, tradução da autora).

Como descrito no componente do planejamento atividades, Imbernón (2008) recomenda estabelecer no planejamento os momentos e as técnicas a se usar. Esses momentos correspondem à avaliação inicial, avaliação formativa e avaliação somativa. A primeira, avaliação inicial, corresponde ao diagnóstico enquanto a avaliação formativa corresponde a observação continua da aprendizagem e a detecção de dificuldades encontradas. Por fim, a avaliação somativa corresponde à comprovação de tarefas de revisão.

\subsection{AULA DE MÚSICA}

A aula de música como qualquer outra aula deve ser preparada e planejada, ela precisa de uma gestão do conteúdo, que se reflita no planejamento. Como já referido, o planejamento indica aonde ir, por que, e como ir. Existem diversas representações de aula que atendem às dimensões dos objetivos defendidos por Veiga (2008) e referentes a finalidades de natureza filosófica e política, gestão educativa, pedagógica e prática pedagógica. Há também representações de aula que atendem aos elementos do planejamento destacados por Imbernón (2008): conhecimentos; organização de ambiente e conteúdo; estruturação da aprendizagem e regulação e retroalimentação do processo.

Considerando os princípios do planejamento de aulas apresentados anteriormente, este tópico se concentrará na aula de música. Inicialmente, far-se-á um pequeno percurso pela história do ensino e aprendizagem da música salientando aquela direcionada para o âmbito da escola de ensino básico. Em seguida, são apresentadas algumas concepções e modelos de aula de música. Entende-se que o planejamento reflete concepções e modelos de aula. O aporte teórico é centrado nos autores Jorquera (2006) e Swanwick (1991). Para melhor entendimento da seleção teórica adotada, acrescenta-se a definição e a classificação de "modelos didáticos" organizada por García Pérez (2000) em que se baseia a classificação de modelos didáticos de aula de música organizada por Jorquera.

Para Jorquera (2006), a aula de música, seus conteúdos e métodos são produtos da tradição e devem ser analisados sob uma perspectiva histórica. Segundo a descrição histórica

\footnotetext{
${ }^{19}$ La finalidad de la evaluación es mejorar la intervención pedagógica de las tareas controlando todos los elementos que intervienen en la programación, para adecuarla cada vez más a los alumnos y comprobar si éstas intervenciones pedagógicas han sido útiles o no. (IMBERNÓN, 2008, p. 131).
} 
apresentada pela autora, observam-se mudanças nas concepções e representações da aula de música.

Sob o ponto de vista histórico, o ensino da música sistematizado na Grécia clássica e na Roma antiga visava à prática individual e instrumental para classes sociais aristocratas com a finalidade de manter o status social. O ensino da música na época medieval realizava--se nos mosteiros cristãos, com ênfase no canto com a origem das scholae cantorum na Europa. Até o século XI, as técnicas empregadas na instrução eram a imitação e a memória, o que sofre modificações com o surgimento do letramento. No século XII, surgem as primeiras universidades e há uma integração com algumas scholae cantorum. No final do medievo, inicia-se uma separação entre a música e a formação religiosa, porém a formação musical continua a ser privilegio das altas castas.

$\mathrm{Na}$ Renascença, a prática instrumental adquire maior importância, quando se inclui a música nos sistemas educativos, sendo um desses exemplos os Ospedali italianos, que foram escolas para órfãos, posteriormente copiados na Alemanha e outros países.

Nos países luteranos, os primeiros textos são impressos para aprender música, de forma sistemática e progressiva, enquanto, na Inglaterra, os salmos são os textos utilizados para aprendizagem de música. Com o desenvolvimento da imprensa e dos textos, são desenvolvidos manuais para instrumentos musicais. No século XVI conferem-se os primeiros títulos de formação em música e, no Século XII, as academias se ampliam a partir do modelo italiano do séc. XIV, consistindo na formação musical para cultivar os interesses cultos da aristocracia.

No século XVII nasce o interesse pela criação de novos sistemas educativos. Jorquera (2006) menciona Komensky, mais conhecido como Comenius, como o precursor da introdução da música no Ensino básico para todos os níveis educacionais, proposta que só foi efetivada no século XIX. No entanto, no século XVIII, Rousseau já escrevia métodos para o ensino da música para crianças, considerando o ensino da música um benefício psicológico e social.

Nos séculos XVIII e XIX surgem novos métodos para o ensino de música, o repertório escolar e o ensino da música em grupo. Francke (1663-1727), por exemplo, propõe educação musical formal de duas horas semanais; Basedow (1724-1790) defende a música para formar indivíduos mais felizes e Rust, que compõe música vocal para o ensino da multiplicação, são autores citados por Jorquera (2006) que desenvolveram princípios pedagógicos para a aula de música na escola. 
No século XIX se evidencia, principalmente, a preocupação com o ensino do letramento musical e, após a Revolução Francesa, criam-se os conservatórios franceses de música, cuja principal finalidade é a aprendizagem da técnica e do solfejo antecipando a prática instrumental. Outros modelos conservatoriais surgem na Alemanha, Suíça e Áustria com a introdução da prática de bandas. O formato de conservatório francês foi seguido no ensino de música das escolas de ensino básico. Nesse período, a ideologia dominante é a reforma social e com ela transforma-se a atitude em relação ao ensino, o que se reflete no chamado paidocentrismo, com a criança como centro nos pressupostos da Escola nova e no acesso a educação para todos - democratização do ensino. Nesse contexto, a educação musical efetivase como experiência e é concebida como ferramenta para ampliar o potencial intelectual e o sentido estético.

Jorquera (2010) sintetiza a história da educação musical em três períodos estruturantes baseados na história da civilização ocidental como é possível observar na seguinte citação: “a história da educação musical ocidental pode ser dividida em três grandes períodos: da Grécia e Roma para o início do século XVII; a partir de então até o século XIX e, desde os pioneiros do século XX até o presente" (Jorquera, 2010, p. 57, tradução nossa). ${ }^{20}$

A história da educação musical reflete representações e concepções de aula de música. Nos períodos históricos o "arranjo estrutural" da aula varia de acordo com os valores, os princípios, o contexto e os objetivos educacionais vigentes. Desta interação do processo de ensino e aprendizagem com o contexto sociocultural surgem modelos didáticos, propostas educativas e métodos de ensino.

\subsubsection{Aula de música e seus "modelos didáticos"}

O termo "modelo didático" é entendido nesta pesquisa sob a perspectiva de García Pérez. Para esse autor, o termo é um instrumento de análise da realidade escolar quanto a prática do ensino-aprendizagem. Em suas palavras, o modelo didático é:

[...] instrumento que facilita a análise da realidade escolar visando a sua transformação. Podemos, assim, caracterizar como diferentes "tipos" modelos didáticos tanto a realidade escolar tradicional como tendências

20 ... la historia de la educación musical occidental se puede dividir en tres grandes períodos: desde Grecia y Roma hasta los comienzos del siglo XVII, desde entonces hasta el siglo XIX y desde los pioneros del siglo XX hasta la actualidad. (Jorquera, 2010, p. 57, tradução nossa). 
transformadoras como também projetos alternativos em construção. (GARCÍA PÉREZ, 2000, p.25) [tradução nossa]. ${ }^{21}$

Garcia Pérez (2000) descreve 4 modelos didáticos para definir a realidade escolar e as transformações desejáveis: 1) didático tradicional; 2) didático tecnológico; 3) didático espontaneísta; e 4) didático alternativo.

O primeiro deles, tradicional diz respeito ao método de aula expositiva; com conteúdo cumulativo, por meio de atividades de exercícios de memorização de conteúdo. É o modelo predominante na história da educação.

O tecnológico identifica o método de aula misto entre expositivo e ativista; o conteúdo sequenciado, dirigido pelo professor e vinculado a problemas sociais e ambientais; as atividades centradas no aluno e técnicas de reprodução de processos de investigação científica; a avaliação centrada na medição de aquisições e condutas observáveis.

As teorias da aprendizagem natural orientam o terceiro modelo, espontaneísta, ou por descobrimento; o conteúdo corresponde aos interesses do aluno e as atividades flexíveis tem como protagonista o aluno observador e descobridor; a avaliação visa a observação de processos de atitudes.

Por último, o Alternativo refere-se ao modelo por investigação. Segundo García Pérez (2000) é o desejável; o conteúdo atende a uma visão relativa, evolutiva e integradora do conhecimento, esse entendido como conhecimento cotidiano, disciplinar, social e ambiental; as atividades centram-se no aluno que investiga com apoio do e pelo professor. A avaliação centra-se na observação continua do projeto como um todo; o eixo é o trabalho por projetos e a problematização.

No quadro 6, a seguir, observa-se a classificação dos modelos didáticos apresentados por García Pérez (2000) e classificados de acordo com os componentes dos planejamentos de aula: métodos, conteúdo, atividades e finalidades.

\footnotetext{
21 ... el modelo didáctico es un instrumento que facilita el análisis de la realidad escolar con vistas a su transformación. Podemos, así, caracterizar como distintos «tipos» de modelos didácticos tanto la realidad escolar tradicional como las tendencias transformadoras, como, asimismo, los proyectos alternativos en construcción. (GARCÍA PÉREZ, 2000, p.25)
} 
Quadro 5 - Classificação de "modelos didáticos" segundo García Pérez (2000)

\begin{tabular}{|c|c|c|c|c|}
\hline \multirow[b]{2}{*}{ COMPONENTES } & \multicolumn{4}{|c|}{ MODELOS DIDÁCTICOS - García Pérez (2000) } \\
\hline & Tradicional & Tecnológico & Espontaneísta-Ativista & $\begin{array}{l}\text { Alternativos } \\
\text { (Ou desejado) }\end{array}$ \\
\hline Métodos & Expositiva & $\begin{array}{c}\text { Expositiva e } \\
\text { ativismo }\end{array}$ & $\begin{array}{c}\text { Descobrimento } \\
\text { Aprendizagem natural }\end{array}$ & Investigação \\
\hline Conteúdo & $\begin{array}{l}\text {-Cumulativo } \\
\text {-Fragmentada } \\
\text {-Proporcionar } \\
\text { informação } \\
\text { social de } \\
\text { cultura } \\
\text {-Transição de } \\
\text { conteúdos }\end{array}$ & $\begin{array}{c}\text {-sequenciado } \\
\text {-vinculados a } \\
\text { problemas sociais } \\
\text { e ambientais } \\
\text {-elaboração do } \\
\text { conhecimento } \\
\text { previamente } \\
\text { determinado }\end{array}$ & $\begin{array}{c}\text {-descobrir a própria } \\
\text { realidade } \\
\text {-pelos interesses do aluno }\end{array}$ & $\begin{array}{l}\text {-visão relativa, } \\
\text { evolutiva e integradora } \\
\text { do conhecimento } \\
\text { - conhecimentos: } \\
\text { cotidiano; disciplinar; } \\
\text { problemática social e } \\
\text { problema ambiental } \\
\text {-interesses, ideias e } \\
\text { concepções dos alunos }\end{array}$ \\
\hline Atividades & $\begin{array}{l}\text {-Exercícios de } \\
\text { reforço } \\
\text {-Memorização } \\
\text {-Reproduzir }\end{array}$ & $\begin{array}{c}\text {-sequenciadas } \\
\text {-dirigidas pelo } \\
\text { professor } \\
\text {-estratégias e } \\
\text { técnicas das } \\
\text { diferentes } \\
\text { disciplinas } \\
\text { científicas } \\
\text { - encontram-se } \\
\text { outras } \\
\text { perspectivas } \\
\text { centradas no } \\
\text { aluno } \\
\text {-tarefas abertas } \\
\text { Reprodução de } \\
\text { processos de } \\
\text { investigação } \\
\text { científica }\end{array}$ & $\begin{array}{c}\text { - pouco programadas } \\
\text {-flexíveis } \\
\text {-abertas } \\
\text {-aluno como protagonista } \\
\text {-observar } \\
\text {-buscar a própria } \\
\text { informação } \\
\text {-cooperação }\end{array}$ & $\begin{array}{c}\text {-investigação do aluno } \\
\text { com apoio do } \\
\text { professor } \\
\text {-problematização }\end{array}$ \\
\hline Avaliação & $\begin{array}{l}\text {-Memorização } \\
\text {-Reproduzir }\end{array}$ & $\begin{array}{l}\text {-Medição de } \\
\text { aquisições } \\
\text {-Medição dos } \\
\text { processos } \\
\text { metodológico } \\
\text { empregados } \\
\text {-Medição de } \\
\text { condutas } \\
\text { observáveis. }\end{array}$ & $\begin{array}{l}\text { - processos } \\
\text { de atitudes }\end{array}$ & $\begin{array}{l}\text {-processo continuo: } \\
\text { sobre estado de } \\
\text { evolução de } \\
\text { concepções ou ideias } \\
\text { dos alunos; da atuação } \\
\text { profissional e do } \\
\text { projeto como um todo. }\end{array}$ \\
\hline Finalidade & Os conteúdos & Os Objetivos & $\begin{array}{l}\text { Aprendizagem e aluno } \\
\text { que aprende por si } \\
\text { mesmo }\end{array}$ & $\begin{array}{l}\text { - conteúdo e processo } \\
\text {-problematização }\end{array}$ \\
\hline
\end{tabular}

Fonte: Aurora, baseada na reelaboração de García Pérez (2000, p.28)

Jorquera (2010), baseada nos “modelos didáticos” de García Perez (2000) realiza uma proposta de classificação para educação musical, porém, a autora adverte que "modelos didáticos" são aproximações provisórias que a partir de continuas avaliações e confrontações são modificáveis.

A autora apresenta 4 (quatro) modelos didático-musicais: 1) académico; 2) prático; 3) comunicativo lúdico e 4) complexo. 
O acadêmico é o modelo de tipo expositivo, baseado no letramento e treinamento instrumental especializado de imitação e memorização e na transmissão de conceitos "enciclopédicos", avalia-se a reprodução. Da mesma forma que o modelo tradicional de Garcia Pérez (2000), o modelo acadêmico é predominante na história da educação musical e, ainda vigente em muitos contextos educativo-musicais.

No modelo prático, o processo de ensino e aprendizagem é mais técnico que o anterior; a finalidade é o virtuosismo alcançado pela repetição de exercícios técnicos; o repertório, de repetição mecânica, é o selecionado pelo professor sobre "grandes obras e compositores"; a avaliação consiste na verificação dos resultados. Esse modelo é muito valorizado a partir do século XIX e ainda vigente na formação de instrumentistas.

O terceiro modelo, comunicativo-lúdico, alude às teorias da chamada escola nova e aos decorrentes modelos de educação musical como Willems, Martenot, Orff, Dalcroze; de caráter ativista; conhecimento fragmentado e com fins social-comunicativos de espetáculo; atividades de motivação centradas no jogo; avaliação de resultados e alguns processos. Esse modelo ganha projeção na primeira metade do século XX e apresenta continuadores no século XXI.

O último modelo, Complexo, é baseado na investigação de significados, contextos, funções e estruturas musicais, o conteúdo atende a manifestações e expressões musicais das diferentes culturas; avaliam-se processos e resultados; o professor é quem guia os processos de aprendizagem. É o modelo mais desejável segundo a concepção de ensino e aprendizagem contemporânea.

Jorquera (2010) concebe a classificação desses modelos a partir das seguintes dimensões: finalidade; conteúdo; teorias do ensino; teorias da aprendizagem; ideias e interesses dos estudantes; currículo; avaliação e relações ente sistema escolar e sistema social.

Como uma aproximação entre as duas perspectivas teóricas, nesta pesquisa adaptou-se o quadro 7 a seguir, apresentando na coluna vertical os componentes usados por García Pérez descritos acima. O quadro original de Jorquera (2010) apresenta na coluna esquerda as 8 dimensões acima mencionadas (ver Anexo B).

Quadro 6 - Classificação de "modelos didáticos” segundo Jorquera (2010)

\begin{tabular}{|c|c|c|c|c|}
\hline COMPONENTES & \multicolumn{4}{|c|}{ MODELOS DIDÁCTICOS - Jorquera (2010) } \\
\hline & \multicolumn{2}{|c|}{ Tradicional } & \multirow{2}{*}{$\begin{array}{c}\text { Comunicativo- } \\
\text { lúdico }\end{array}$} & \multirow{2}{*}{ Complexo } \\
\hline & Acadêmico & Prático & & \\
\hline Métodos & $\begin{array}{l}\text {-Explicativo } \\
\text {-Treinamento } \\
\text {-Transmissão }\end{array}$ & $\begin{array}{c}\text {-Prático } \\
\text {-Imitação } \\
\text {-Repetição }\end{array}$ & $\begin{array}{c}\text {-Ativista } \\
\text {-Educação ativa, com } \\
\text { modelos de: Orff, }\end{array}$ & $\begin{array}{c}\text {-Investigação } \\
\text { (conceitual e } \\
\text { criativa) }\end{array}$ \\
\hline
\end{tabular}




\begin{tabular}{|c|c|c|c|c|}
\hline & & & $\begin{array}{l}\text { Martenot, Willems, } \\
\text { Dalcroze. }\end{array}$ & $\begin{array}{l}\text {-Baseada na } \\
\text { antropologia da } \\
\text { música }\end{array}$ \\
\hline Conteúdo & $\begin{array}{c}\text {-Materiais } \\
\text { escritos } \\
\text { (partitura) } \\
\text {-Conceitos } \\
\text {--Conhecimento } \\
\text { enciclopédico de } \\
\text { Obras e autores } \\
\text { canonizados } \\
\text {-letramento }\end{array}$ & $\begin{array}{c}\text {-Produção técnica } \\
\text { (Instrumental, compor, } \\
\text { improvisar) } \\
\text {-Repertório } \\
\text { selecionado pelo } \\
\text { professor }\end{array}$ & $\begin{array}{l}\text {-Caráter recreativo e } \\
\text { de espetáculo } \\
\text {-Conhecimento } \\
\text { técnico-musicais } \\
\text {-Fragmentado } \\
\text {-Transmissão cultural }\end{array}$ & $\begin{array}{c}\text {-Significados, } \\
\text { contextos, } \\
\text { funções, estruturas } \\
\text { musicais } \\
\text {-Manifestações e } \\
\text { expressões } \\
\text { musicais das } \\
\text { diferentes culturas }\end{array}$ \\
\hline Atividades & $\begin{array}{c}\text {-Audição } \\
\text { explicativa previa } \\
\text { (percepção) } \\
\text {-Repertório } \\
\text { selecionado } \\
\text {-Letramento } \\
\text {-Analise de } \\
\text { estruturas } \\
\text { musicais } \\
\text {-aulas individuais } \\
\text {-escutar, } \\
\text { assimilar }\end{array}$ & $\begin{array}{c}\text {-Individuais } \\
\text {-Funcionais } \\
\text {-Imitação e repetição } \\
\text { de exercícios técnicos } \\
\text {-repertório mecânico } \\
\text { de "grandes obras" e } \\
\text { de "grandes } \\
\text { compositores" } \\
\text {-No repertório escolar } \\
\text { incluem-se trechos de } \\
\text { obras conhecidas e } \\
\text { simplificadas. } \\
\text {-Na escola o caráter da } \\
\text { música é hedonista. }\end{array}$ & $\begin{array}{l}\text {-Atividades grupais } \\
\text {-Uso do jogo como } \\
\text { ferramenta de } \\
\text { motivação } \\
\text {-O professor é o guia } \\
\text { da aprendizagem de } \\
\text { repertórios } \\
\text {-Consideram-se as } \\
\text { competências reais } \\
\text { dos estudantes. }\end{array}$ & $\begin{array}{c}\text {-Explorar } \\
\text {-Improvisar } \\
\text {-Compor } \\
\text {-Repertório } \\
\text { combinados com } \\
\text { professor } \\
\text {-o professor é o } \\
\text { guia dos processos } \\
\text {-pratica razoada e } \\
\text { de relações com a } \\
\text { própria } \\
\text { aprendizagem } \\
\text { realizada. }\end{array}$ \\
\hline Avaliação & $\begin{array}{c}\text {-Imitação } \\
\text {-Reprodução }\end{array}$ & $\begin{array}{l}\text { - Verificação de } \\
\text { resultados }\end{array}$ & $\begin{array}{c}\text {-Avaliação de } \\
\text { resultados e de alguns } \\
\text { processos }\end{array}$ & $\begin{array}{l}\text {-Avaliação de } \\
\text { processos e } \\
\text { resultados }\end{array}$ \\
\hline Finalidade & $\begin{array}{l}\text {-O conteúdo } \\
\text {-Formação } \\
\text { instrumental } \\
\text { especializada }\end{array}$ & -Virtuosismo & $\begin{array}{c}\text {-Música como } \\
\text { linguagem } \\
\text { (descontextualizado) } \\
\text {-Fines individuais } \\
\text { (desenvolvimento } \\
\text { pessoal) } \\
\text {-Fines sociais } \\
\text { (sociedade do } \\
\text { espetáculo) }\end{array}$ & $\begin{array}{l}\text {-Compreender a } \\
\text { realidade. } \\
\text {-Promover a } \\
\text { construção do } \\
\text { conhecimento } \\
\text { musical. } \\
\text {-Conhecimento } \\
\text { humano } \\
\text { contextualizado. }\end{array}$ \\
\hline
\end{tabular}

Fonte: Aurora, adaptação da elaboração de Jorquera (2010, pp.68-70)

Swanwick (1991) propõe um outra perspectiva teórica para classificar os modelos de aula de música e os processos de ensino e aprendizagem musical. Ele baseia sua proposta pedagógico-musical na teoria de Piaget, quanto aos processos humanos fundamentais de consciência do mundo e a integração a ele numa linha evolutiva. Nessa teoria, "o jogo constitui a característica fundamental e considera-se intrinsicamente ligado a toda obra artística" (SWANWICK, 1991, p. 62).

A teoria do desenvolvimento musical de Keith Swanwick inclui: 4 (quatro) dimensões da aprendizagem musical; 4 (quatro) tipos ou modelos de ensino e aprendizagem de música; 
princípios pedagógicos para Educação Musical e atividades musicais relacionadas com o fazer musical.

As dimensões da aprendizagem musical correspondem a etapas, numa linha evolutiva de desenvolvimento, descrita como uma espiral ascendente, porém cíclica, etapas às que o indivíduo se reinsere reiteradamente a cada contato com a música, como explanado pelo autor na seguinte citação:

a espiral evolutiva é reativada toda vez que há encontro com a música e, especificamente, quando nos deparamos com uma nova peça como intérpretes ou como ouvintes ou quando compondo ou improvisando. A primeira e mais vívida impressão da música é sempre a superfície sensorial, especialmente se temos sido privados de música durante muito tempo. Diferentemente das crianças, as pessoas com alguma experiência podem assimilar outros elementos relacionados com novas facetas significativas à resposta. ${ }^{22}$ (SWANWICK, 1991, p. 91) [tradução nossa]

Swanwick (1991) define 4 dimensões ou estágios evolutivos do desenvolvimento musical: Materiais; Caráter Expressivo; Forma e Valor. Cada uma refere-se às etapas relacionadas com os processos fundamentais de desenvolvimento da teoria Piagetiana e que Swanwick (1991) organiza na sua "espiral evolutiva", conhecida como "Teoria Espiral de Desenvolvimento Musical” (TEDM). A espiral está organizada sequencialmente em níveis de desenvolvimento baseados na teoria do Jogo de Piaget: Domínio; Imitação; Jogo imaginativo e Metacognição. Cada Dimensão possui dois modos evolutivos, relacionados a etapas ou estágios (ver fig 11):

1 Materiais, no nível do Domínio, diz respeito aos modos evolutivos sensorial e manipulativo.

2 Expressão, no nível da Imitação contém os modos evolutivos pessoal e vernáculo.

3 Forma, nível do Jogo imaginativo refere-se os modos evolutivos especulativo e idiomático.

4 Valor, no nível da Metacognição contém os modos evolutivos simbólico e sistemático.

As dimensões são vivenciadas nos diferentes "modos" e "níveis" do processo, dependendo do contexto e grau de desenvolvimento pessoal. Swanwick (1991) exemplifica

\footnotetext{
22 ... la espiral evolutiva se reactiva cada vez en el encuentro con la música y, concretamente, cuando abordamos una nueva pieza como intérprete o como oyentes, o cuando componemos e improvisamos. La primera y más viva impresión de la música es siempre su superficie sensorial, sobre todo si nos hemos visto privados de la música durante mucho tiempo. A diferencia de los niños muy pequeños, las personas con cierta experiencia pueden asimilar otros elementos que atañen nuevas facetas significativas a la respuesta. (SWANWICK, 1991, p. 91)
} 
isto com os modos evolutivos na Dimensão Materiais, argumentando que o nível de domínio ou controle é qualitativamente diferente. A seguir a descrição nas suas palavras:

Há, então três níveis qualitativamente diferentes de controle musical: quanto aos materiais mínimos (manipulativo) baseia-se na capacidade para repetir sons, por exemplo na aquisição do tempo continuo no compasso; materiais limitados (vernáculo) descreve a capacidade para produzir padrões e frases convencionais; materiais tecnicamente desenvolvidos (modo idiomático) indica que há recursos estilísticos reconhecíveis assimilados no repertorio da ação musical. (SWANWICK, 1991, p. 171).

Os diferentes modos e níveis de desenvolvimento musical para o autor são a mistura e a integração entre o aspecto de desenvolvimento individual e o social. O âmbito individual ou pessoal, da intuição e da criatividade, atribuído a coluna esquerda, refere-se a modos do prazer sensorial; da expressão; da especulação; e do simbólico (Fig 11). No âmbito social, na coluna direita, o autor identifica a tendência do indivíduo se adequar aos valores, normas e regras sociais e culturais, é o âmbito da sociedade e refere-se aos modos manipulativo, vernacular, idiomático e sistemático. Em suas palavras refere-se: “... à habilidade manipulativa ou técnica; ao domínio das convenções vernáculas da produção musical e a autenticidade idiomática e estilística.” (SWANWICK, 1991, p. 92).

Como acima dito, nas dimensões ou estágios Materiais; Expressão; Forma e Valor o indivíduo se reinsere reiteradamente. A seguir, na figura 11, observa-se a imagem da "espiral do desenvolvimento musical" elaborada por Swanwick e Tillman: 


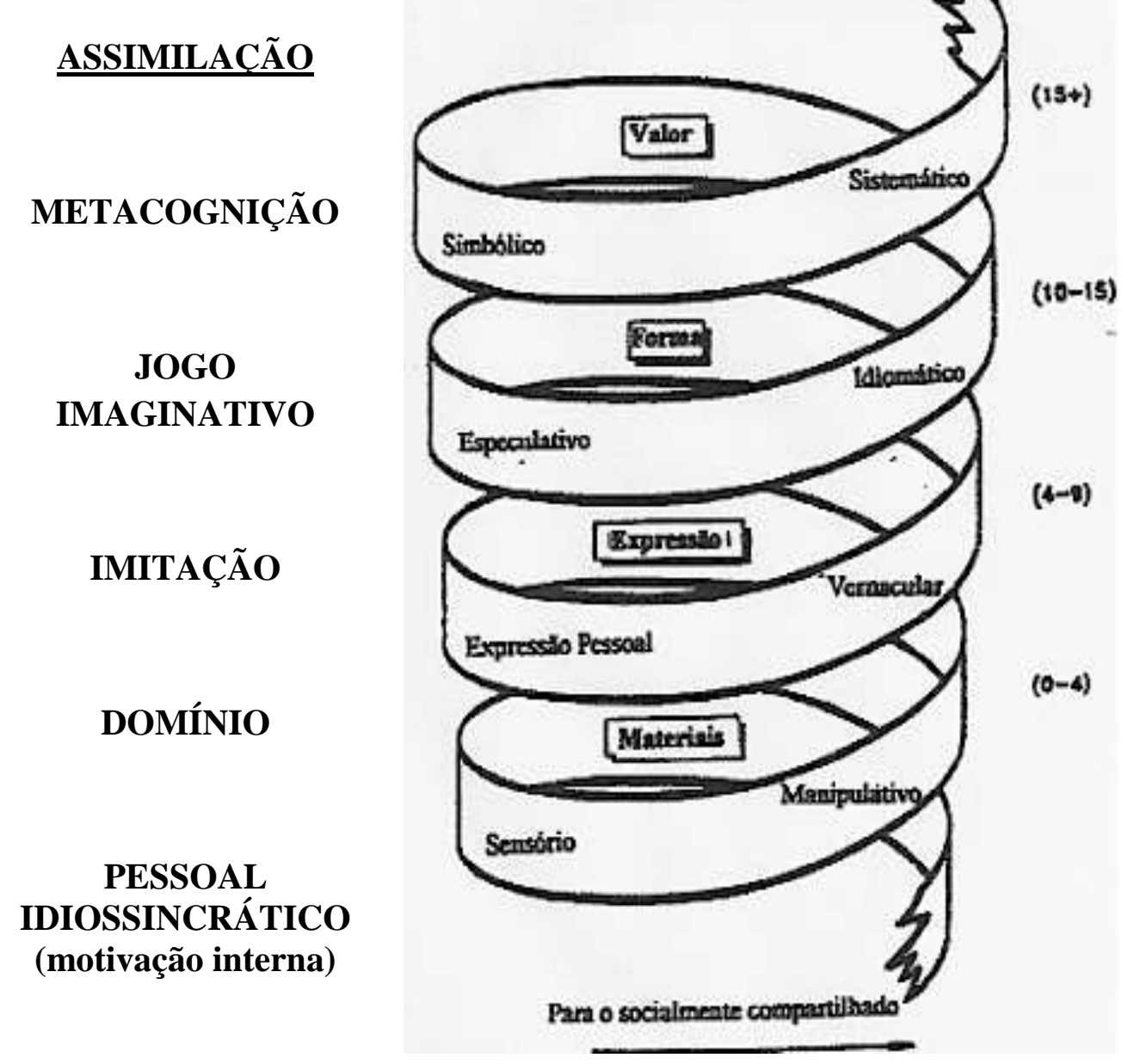

\section{ACOMODAČ̃̃̃O}

Figura 11 - Espiral de desenvolvimento musical de Swanwick e Tillman.

Fonte: SWANWICK, 1991, p. 85

Com relação aos tipos de ensino e aprendizagem de música, o autor atribui "metáforas" aos modelos docentes: professor Caixa Postal; professor Jardineiro; professor Agente Cultural e professor como Músico. Swanwick (1993) discute os tipos e modelos de ensino de música a partir da atuação e do comportamento do professor.

O professor como Caixa Postal ou do tipo tradicional desenvolve a aula centrada no conteúdo da disciplina. A sua finalidade é a transmissão da "alta" cultura ocidental e os professores como transmissores da cultura selecionam o conteúdo e as atividades e decidem o que é importante de se aprender. As atividades baseiam-se no desenvolvimento de habilidades instrumentais e em ler e escrever música. A avaliação consiste no teste e medição dos resultados. 
A aula de música centrada no desenvolvimento natural da criança é uma característica do professor Jardineiro. As atividades giram em torno da prática musical. Os repertórios tomam recursos das culturas oriental e ocidental misturando aspectos folclóricos e contemporâneos. Valoriza-se o trabalho com criatividade com um dos objetivos: "auto expressão", conhecimento e compreensão da música por meio da composição, objetivos esses dos que dependem as atividades. Aproveitam-se variedade de materiais. O professor tem a função de: "estimular, questionar e aconselhar, ao invés de mostrar e dizer. O professor se torna um jardineiro ao invés de um instrutor" (SWANWICK, 1993, p.25).

O professor Agente Cultural ministra sua aula com uma visão sociológica, integrando diferentes ambientes culturais, etnias e tecnologias, aspectos que influenciam nos repertórios e que ampliam e enriquecem a experiência musical.

Finalmente, o professor como Músico é aquele que segue os princípios fundamentais de sentimento de realização e de experiência musical direta.

Como princípios em Educação Musical, Swanwick (1991) aponta diretrizes para o "fazer" do professor em sala de aula: 1) propiciar e fazer com que os alunos experimentem sentimento de realização, referindo-se a atitudes de reconhecimento listadas por Swanwick (1993) baseando-se em Bruner: curiosidade, desejo de competência, imitação, necessidade de interação social e 2) Experiência musical direta, como compositor, executante ou ouvinte, visando a compreensão, a sensibilidade e o desfrute musical.

Com relação às Atividades Musicais, Swanwick (1991) considera uma aula de música como uma experiência prática musical baseada em atividades que permitem se relacionar diretamente com música. Elas são: composição; literatura; apreciação; técnica e execução ou performance (CLASP). Essas atividades também permitem avaliar os produtos musicais. O modelo de atividades musicais foi traduzido para o português como (T)EC(L)A: técnica, execução, composição, literatura e apreciação. As atividades principais são as atividades relacionadas a experiência musical direta composição, literatura e apreciação e representam o saber fazer. A técnica e a literatura são atividades periféricas e secundárias relacionadas ao conhecimento sobre música, elas não refletem a experiência musical direta.

A Teoria do Desenvolvimento Musical de Swanwick propõe um modelo educativo centrado no fazer musical e no professor como músico. Sua espiral do desenvolvimento musical pode ser fundamento teórico para a gestão do conteúdo musical e o "como" de desenvolvê-lo numa aula de música. Numa aproximação com os modelos didáticos apresentados por Jorquera (2010), o modelo didático proposto por Swanwick (1991) pode ser 
classificado na dimensão complexa, pois privilegia o fazer musical em atividades de compor, improvisar, explorar, em que a produção de conhecimento e o conhecimento contextualizado são valorizados e estimulados. O professor é guia e mediador do processo de ensino e aprendizagem musical e a avaliação é processual e pontual. 


\section{PROCEDIMENTOS METODOLÓGICOS: O CORPUS DOCUMENTAL E SUA INTERPRETAÇÃO}

O objeto desta pesquisa são as aulas de música disponibilizadas no "Espaço Aula" do Portal do Professor do MEC. Elas são representações da gestão do ensino e da aprendizagem de música na Educação Básica, disponibilizadas por professores, aspecto que lhes dá o caráter de pesquisa social.

A adoção duma abordagem quali-quantitativa com método de análise documental permite o desenvolvimento do objetivo desta investigação que consiste em descrever e analisar as aulas de música disponibilizadas no "Espaço da Aula" do Portal do Professor do MEC, identificando: autoria e coautoria; como são planejadas essas aulas, quais os conteúdos, objetivos; atividades, recursos e avaliações disponibilizados. Isto envolve entender o Portal como um REA, como um espaço de socialização e comunicação, em que ideias, crenças, valores e concepções são compartilhados. As aulas são fontes documentais que expressam essas representações e apresentam conteúdos que se tornam dados sociais na investigação.

As fontes documentais ou fontes de informação são o vestígio construído e deixado nos meios de comunicação, de diferente natureza, que incluem textos como documentos escritos, imagens como materiais visuais e, materiais sonoros (BAUER et al, 2003; CELLARD, 2008; FLICK, 2009; LAVILLE \& DIONNE, 1999; OLIVEIRA, 2007).

Na pesquisa em ciências sociais, conforme Bauer et al (2003), os dados sociais são representações e visões do mundo que se conhece e se experiência, eles são resultantes dos processos de comunicação, são esses dados que interessam aos pesquisadores sociais. Os processos se apresentam de dois modos: formal e informal. $O$ primeiro se refere a comunicação que exige regras e competência especializada, nas palavras dos autores, "os dados formais reconstroem as maneiras pelas quais a realidade social é representada por um grupo social.” (BAUER, GASKELL, ALLUM, 2003, p.22). A comunicação informal trata das manifestações do falar, do cantar, do desenhar ou outras, surgidas especialmente pelo impulso do momento.

As aulas do Portal apresentam uma dimensão formal e constituem o corpus teórico desta investigação. Nas palavras de Flick (2009) delimitar o corpus teórico é fundamental “para estabelecer os dados para análise” (FLICK, 2009, p.52).

Neste capitulo, portanto, é apresentado, primeiramente, o conceito de pesquisa documental e o estudo de documentos com NTICs. Em seguida, são apresentadas a 
construção do corpus teórico desta investigação e sua interpretação, ou seja, os procedimentos de seleção, organização, análise e interpretação dos dados.

\subsection{A PESQUISA QUALI-QUANTITATIVA: APROXIMAÇÕES E COMPLEMENTARIEDADE}

A abordagem quali-quantitativa refere-se, nesta pesquisa, à combinação de dois paradigmas investigativos, um complementando o outro. Essa complementariedade envolve tanto as questões epistemológicas quanto o método.

Quanto às questões epistemológicas, a pesquisa qualitativa, segundo Flick (2009), responde às posturas teóricas de ordem subjetiva, entendendo o subjetivo sob o ponto de vista tanto individual quanto social, assim como observado e melhor explicitado na seguinte citação: "Cada uma dessas posturas conceitua, de diferentes maneiras, o modo como estes sujeitos em estudo - suas experiências, ações e interações - relacionam-se ao contexto no qual são estudados" (FLICK, 2009, p. 232).

$\mathrm{Na}$ pesquisa qualitativa de abordagem social Flick (2009) destaca as seguintes tendências teóricas: o interacionismo simbólico, a etnometodología, e os modelos estruturalistas. O interacionismo simbólico trata da maneira como o indivíduo constrói significados de objetos, de experiências, de eventos ou do mundo; o instrumento usado para a sua análise é a reconstrução do ponto de vista subjetivo geralmente empregando-se as "narrativas autobiográficas". A etnometodología trata dos interesses sobre a cotidianidade das pessoas e os métodos empregados por um grupo social localmente contextualizado, na produção da realidade cotidiana; o instrumento mais comum para a análise das situações cotidianas é a "análise de conversação". Os modelos estruturalistas têm interesse na percepção e elaboração da realidade social, consideram-se as experiências e atividades dos sujeitos em diferentes níveis, sendo um desses os chamados "estruturas profundas" que se referem aos níveis determinados culturalmente, nos quais os indivíduos agem na cotidianidade, sem intenção. Dentro desse modelo o autor classifica a chamada "hermenêutica objetiva" e as "representações sociais" como modelo pós-estruturalista.

Outro autor, Triviños (2012), destaca a grande influência da abordagem estruturalista dentro da pesquisa social, nos temas da crítica literária; nos estudos da linguística, com 
Saussurre como grande representante; na psicologia e educação com representantes como Vigotsky e Piaget; na antropologia e na sociologia com Parsons, Weber e Malinowski.

Uma das diferenças entre pesquisa qualitativa e qualitativa, conforme apontado por Flick (2009), é que a qualitativa "usa o texto como material empírico (em vez de números)", enquanto a pesquisa quantitativa, por sua vez, usa dos dados estatísticos e quantifica uma frequência ou se realiza um levantamento.

Na pesquisa, o método se refere à geração de dados nos processos de coleta, de análise e interpretação de dados mensuráveis. Refere-se ao processo de seleção e interpretação na pesquisa. Ao se referir ao conceito de interpretação, não necessariamente esse deve ser quantificador, como observado nas palavras de Laville (2008), “um saber que repousa sobre a interpretação não possibilita necessariamente um procedimento experimental e quantificador nem a reprodutibilidade, ainda que isso não seja excluído.” (LAVILLE \& DIONNE, 2008, p. 43).

A combinação das pesquisas qualitativas e quantitativas, segundo Flick (2009), ocorre de diferentes modos: pela combinação de métodos quantitativos e qualitativos; pela combinação de etapas no processo de pesquisa, podendo ser sequenciadas ou não; pela combinação dos dados, transformando dados qualitativos em quantitativos ou vice-versa, quando dados de frequência podem fornecer novas respostas; pela questão da generalização das descobertas. Estas se referem à amostragem e a pergunta em volta, descritas nas palavras do autor: "As questões relevantes aqui são 'quais casos?' em vez de 'quantos?" (FLICK 2009, p.47); pela "apropriabilidade", referindo-se ao assunto em estudo; e pela associação dos resultados, o autor reconhece esse tipo de combinação como o mais frequente, essa combinação realizando-se segundo os diferentes objetivos propostos podendo ser a ampliação de conhecimento ou a validação das descobertas.

Outros autores também apontam à integração das pesquisas qualitativa e quantitativa visando quebrar a dicotomia entre as duas, Bauer (2003) atenta sobre esse aspecto, afirmando que não há quantificação sem qualificação, porquanto deve ser identificado o fato social, como observado na seguinte citação:

A mensuração dos fatos sociais depende da categorização do mundo social. As atividades sociais devem ser distinguidas antes que qualquer frequência ou percentual possa ser atribuído a qualquer distinção. É necessário ter uma noção das distinções qualitativas entre categorias sociais, antes que se possa medir quantas pessoas pertencem a uma ou outra categoria. (BAUER et al, 2003, p.24). 
Os autores também apontam para a interpretação qualitativa realizada na análise estatística, desmitificando-se assim as ideias sobre resultados significativos fornecidos unicamente por estatística numérica. Deixa-se especialmente à abordagem quantificativa a coleta de dados e as questões de quantidade; mas esclarecem que a abordagem das duas pesquisas realiza-se numa visão holística permitindo "incluir a definição e a revisão de um problema, sua teorização, a coleta de dados, a análise dos dados e a apresentação dos resultados." (BAUER et al, 2003, p.26).

Desde essa perspectiva, considera-se que a pesquisa social científica pode incluir nos seus processos a combinação das duas abordagens.

\subsection{A ANÁLISE DOCUMENTAL}

Uwe Flick (2009, p.231) define a análise documental a partir de 2 tipos de abordagem: (1) como estratégia de complemento para outros métodos como a etnografia ou a entrevista e

(2) como método autónomo, em que os fatos ou a realidade estudada estão na informação documentada, ou seja, o foco está nos documentos textuais.

Segundo Triviños (2012), a análise documental é um tipo de estudo descritivo, geralmente realizado na educação, tendo como foco o conhecimento duma comunidade. Para o autor, a análise documental "fornece ao investigador a possibilidade de reunir uma grande quantidade de informação sobre leis estaduais de educação, processos e condições escolares, planos de estudo, requisitos de ingresso, livros-texto,...” (TRIVIÑOS, 2012, p. 111).

A análise documental consiste pois em descrever, analisar e interpretar documentos, de natureza textual, visual e sonora com o objetivo de responder às questões de pesquisa. Segundo Laville e Dione (1999, p.167-168), os “documentos aportam informações diretamente: os dados estão lá, resta fazer sua triagem, criticá-los, isto é, julgar sua qualidade em função da necessidade de pesquisa, codificá-los ou categorizá-los”. Na visão desses autores, a coleta de dados envolve reunir os documentos, organizá-los, descrever seu conteúdo e interpretá-los.

$\mathrm{Na}$ análise documental os documentos não se apresentam como simples ferramentas que fornecem dados na pesquisa senão documentos que podem ser vistos como tema da pesquisa. 
Analisar o objeto de estudo como documento é pensá-lo como fonte documental. Oliveira (2007) atenta para as diferenças entre pesquisa bibliográfica e pesquisa documental: "a documental caracteriza-se pela busca de informações em documentos que não receberam nenhum tratamento científico, como relatórios, reportagens de jornais, revistas, cartas, filmes, gravações, fotografias, entre outras matérias de divulgação" (OLIVEIRA 2007, p. 69). A pesquisa documental baseia-se, portanto, em fontes documentais que não passaram por um tratamento científico ou analítico, esses documentos não são ainda resultado de pesquisas. A pesquisa bibliográfica se realiza sobre documentos científicos, como artigos científicos, livros, ensaios, esses documentos são fontes no que o pesquisador entra em contato com as contribuições de diversos autores e documentos que falam do tema do interesse.

O método de análise documental como método autônomo na abordagem quali-quantitativa permite o seu uso desde a perspectiva de coleta, análise e interpretação.

\subsection{O CORPUS DOCUMENTAL}

Os documentos nas palavras de Flick (2009) "representam uma versão específica de realidades construídas para objetivos específicos..." (FLICK 2009, p.234). Conforme López Yepes $(1976 ; 2013)$ o documento deve se definir pelos seus componentes e funções: suporte físico; conteúdo informativo e potencialidade na transmissão e capacidade para transformar essa informação numa nova. Prior (2003) atenta para o fato de que um documento é definido para além de uma apresentação física estática eles podem ser compreendidos "como campos, estruturas e redes de ação",23 (PRIOR, 2003, p.2). Esses incluem as pessoas que os produzem, as pessoas que o usam e as suas representações, parafraseando o autor eles são: os criadores, os usuários e os ajustes que dele se façam. Eles mais do que ser integrados ao campo de estudo, são em si mesmos o campo a ser estudado. Flick (2009) define campo como o termo para designar uma instituição, uma subcultura, uma família ou um grupo específico.

Os documentos distinguem-se pelas dimensões de autoria e de acesso. Os primeiros podem ser oficiais ou pessoais, se oficiais o documento pode ser privado ou público. A segunda dimensão, de acesso, classifica-se em: fechado; restrito; aberto e de publicação aberta. Os fechados não são acessíveis a terceiros.

23 “...we have to move away from a consideration of them as stable, static and pre-defined artefacts. Instead we must consider them in terms of fields, frames ant networks of action.” (PRIOR, 2003, p.2). 
Flick (2009) identifica ainda os documentos como disponíveis em textos e em arquivo eletrônico: "os documentos estão normalmente disponíveis como textos (de forma impressa), podendo também estar na forma de um arquivo eletrônico (por exemplo, um banco de dados)" (FLICK 2009, p.231). Os REA pertencem ao grupo de documentos digitais, de arquivo eletrônico, são documentos de licença e formato aberto; ou seja, de formato aberto sem a restrição de um programa ou software específico no que tenha que ser lido; e apresentam licença aberta ao serem publicados, disponibilizados e acessíveis a qualquer um interessado, com a possibilidade de serem copiados, modificados ou partilhados, esses, dependendo do interesse do autor quanto ao uso que legalmente lhe queira dar, podendo conter neles os direitos legais de autoria, como é o caso das aulas de música postadas no "espaço da Aula" do Portal do Professor.

Os documentos são construídos e consumidos de diferentes formas e com diversas finalidades, Prior (2003) considera que os documentos por ser lidos e relidos em diferentes épocas e contextos, são instáveis e flexíveis, eles, na pesquisa científica são observados na mesma proporção que a fala e o comportamento humano. Os documentos são uma forma de contextualização da informação numa análise documental.

O documento deve cumprir várias características que respondem aos critérios de autenticidade; credibilidade; representatividade e significação. A autenticidade se refere aos documentos originais ou não, os originários são conhecidos como documentos primários quando criado em primeira instância; são secundários quando o assunto é sobre o documento original e é terciário quando se trata de fontes para encontrar outros documentos, Flick (2009) aponta como exemplo os catálogos de biblioteca. A credibilidade referindo-se à confiabilidade do documento, sem distorções. A representatividade refere-se ao reconhecimento, à tipicidade, se ele é típico ou não. A significação refere-se ao significado individual ou social, tanto para o autor como para o usuário que no caso é o pesquisador.

O processo realizado com o método de análise documental, na sua análise, segundo Flick (2009), pode ser aplicar no mesmo processo seguido na análise de entrevista, porém a utilização como método autónomo compreende muito mais do que análise, como a obtenção de toda informação documentada sobre a realidade em estudo. Coleta, seleção, analise, e interpretação são componentes do método.

Aspectos indicados para se ter em conta quando a adopção do método de análise documental, quanto ao documento são: além da autoria, referente ao tipo primário ou secundário do documento; o objetivo com que ele foi produzido; as circunstancias; o 
contexto; e a sua utilização. Aspectos esses, todos revisados durante este processo de pesquisa.

O passo principal apontado por Flick (2009) na análise documental é a construção do corpus que se refere ao processo da amostragem, seja para selecionar documentos que visem a reconstrução de um caso ou para ter uma amostra representativa de todos os documentos.

\subsection{OS DOCUMENTOS NA PESQUISA E AS NTICS}

$\mathrm{Na}$ atualidade, a elaboração de documentos inclui o uso das NTICs na sua grande variedade de possibilidades, permitindo busca, leitura, registro e organização da coleta, sistemas de análise, ou objeto de estudo como observado na seguinte afirmação:

A pesquisa qualitativa não escapa aos efeitos da revolução digital e tecnológica do início do século XXI [...] além da área de pesquisa, a internet tornou-se também parte da vida cotidiana de muitas pessoas. ...considerando o uso e o acesso amplamente difundidos deste meio, não é nenhuma surpresa que a internet tenha sido descoberta como objeto de pesquisa, mas também como uma ferramenta a ser usada para a pesquisa. (FLICK, 2009, p.238, 239).

O autor mencionado observa que os métodos usados com uso da internet são os mesmos de qualquer pesquisa, mas transferidos ao campo virtual, apontando como condição necessária, no caso de uma pesquisa online, o conhecimento dos diferentes métodos tradicionais de pesquisa, para desta forma, acontecer a transferência de qualquer método para a pesquisa em internet.

As NTICs são também um lugar, onde acontecem formas e objetos de comunicação, em que, no espaço virtual, se formam comunidades e grupos sociais, bem como virtuais, assim como observado na seguinte afirmação:

[...]pode-se estudar a internet como um tipo de ambiente social ou cultural na qual as pessoas desenvolvem formas específicas de comunicação ou, às vezes, identidades específicas. ...Como tantos estudos ...já demonstraram, a tecnologia não deve ser vista somente como algo conhecido e pressuposto, pois seu uso e seu impacto são fortemente influenciados pelas representações e pelas crenças referentes a ela por parte de usuários e não-usuários. (FLICK, 2009, p.246). 
Um dos métodos que se transferem ao contexto virtual usando a internet é a análise documental, ali se encontra uma grande variedade de formas e tipos de documentos conectados ou não com outros documentos.

O documento na internet é uma forma especial de texto, tanto pela sua forma de apresentação quanto pelas possibilidades de interconexão que oferece. Vinculado a essas possibilidades, Flick (2009) aponta como uma das caraterísticas do documento web, a hipertextualidade incluindo-se nessa a não-linearidade, a conexão dum texto com outros e a impermanência.

Texto é uma forma de escrever organizada de forma sequencial, continua, dirigida pelo autor e seguida pelo leitor, com um conteúdo e objetivo específico. O Hipertexto é definido como uma ferramenta e sistema de escrita não linear, em rede, uma nova estrutura narrativa e de organização de informação e comunicação que permite ao "utilizador" (nome dado ao leitor que usa o hipertexto) ligar informações trasladando-se de uma à outra livremente através de Nós que são as unidades que permitem navegar e integrar a informação.

A linearidade refere-se a organização sequencializada realizada no texto tradicional possuindo um começo e um fim, a não linearidade é o texto com a possibilidade de saltar para outros textos ou bem para segui-lo sem uma ordem em sequência. A conexão com outros textos é a possibilidade de relacionar ou conectar um texto com outros, podendo incluir-se imagens ou sonidos; a impermanência refere-se a condição de continua atualização e modificação, da possibilidade de ser retirados ou disponibilizados novamente.

Para Flick (2009), o ponto de partida numa pesquisa ou no começo duma análise com uso da internet não tem uma ordem fixa. Adverte para o uso de diferentes ferramentas de busca de documentos sobre o assunto em questão porquanto uma só não seria suficiente, pelo fato delas se mostrarem só parcialmente. Recomenda o autor o uso de copias e repositórios pessoais dos documentos importantes durante a pesquisa; retornar aos websites em vários momentos da pesquisa pois frequentemente estes sofrem modificações.

Os documentos elaborados e encontrados na internet são produzidos por pessoas que refletem uma cultura, uma sociedade.

O uso dos recursos é embebido, por assim dizer, das histórias, medos, esperanças ou opiniões que sobre a tecnologia circulam e se trocam no espaço social. Ou seja, toda a tecnologia é um campo de representações culturais: não há na sociedade computadores ou quadros eletrônicos "per se", tecnologicamente puros, porque eles só têm status na dinâmica humana que 
os incorpora, rejeita ou reutiliza. A tecnologia é sempre tecnologia-cultura. (LIZARAZO, 2009, p.7) [tradução nossa]. ${ }^{24}$

Os documentos são observados como contextos sócio simbólicos onde se estabelecem sentidos e significados.

\subsection{BUSCA E SELEÇÃO DAS PROPOSTAS DE AULAS DE MÚSICA DO PORTAL}

A seleção das propostas de aulas de música no Portal para análise se desenvolveu em 6 momentos: 1) navegação, busca e levantamento de aulas no Portal; 2) busca avançada por nível de ensino e primeira seleção de aulas; 3) seleção de aulas por meio de sorteio para amostragem aleatória; 4) organização das aulas em tabelas e gráficos; 5) categorização das aulas do Portal; 6) interpretação quantitativa e qualitativa dos dados.

A seguir descreve-se detalhadamente cada um desses momentos.

\subsubsection{Navegação, busca e levantamento de aulas no portal}

Buscando na internet, encontrou-se o endereço do Portal com a palavra-chave "Portal do Professor". O primeiro contato com o Portal foi realizado pela navegação do site acessado pelo endereço http://portaldoprofessor.mec.gov.br/ .

Nesse primeiro momento, realizou-se uma visualização e navegação pelo site, quando foram observados a estrutura, funcionamento e organização do REA-Portal do Professor e realizou-se a primeira busca e levantamento de aulas no Portal.

$\mathrm{Na}$ visualização da página observa-se um menu com 7 opções de seleção de abas disponibilizadas como links ou páginas denominadas "grandes áreas"25: "Espaço da Aula"; "Jornal do Professor"; "Conteúdo Multimídia"; "Cursos e Materiais"; "Interação e

\footnotetext{
${ }^{24}$ El uso de los recursos está impregnado, por decirlo así, de las narraciones, los temores, las esperanzas o las opiniones que sobre la tecnología circulan y se intercambian en el espacio social. Esto es, toda tecnología es en un campo de representaciones culturales: no hay en la sociedad computadoras o tableros electrónicos per se, tecnológicamente puros, porque sólo tienen estatuto en las dinámicas humanas que los incorporan, los rechazan o los reutilizan. La tecnología es siempre tecnología-cultura ... (LIZARAZO, 2009, p.7).

${ }^{25}$ A terminologia "grande área" é usada pelo próprio Portal.
} 
Comunicação"; "Links"; "Plataforma Paulo Freire”, descritas no capítulo 2.2 (ver Figura n³, p.35).

$\mathrm{Na}$ navegação pela página da grande área "Espaço da Aula", local onde são disponibilizadas as aulas, visualizaram-se novos links ou páginas disponibilizadas nas abas do "Espaço da Aula": "Sugestões de Aulas", "Criar Aula", "Orientações" e "Minhas Aulas", cada uma delas explicadas no capítulo 2 desta Dissertação.

A navegação na aba "Sugestões de Aula" é dividida nos elementos "aula" e "coleções de aula". No elemento "Aula" são visualizadas 2 possibilidades de busca por aulas de música: as opções simples e avançada.

Realizou-se uma busca e levantamento pela opção simples usando a palavra música.

Na busca efetivada no levantamento inicial foi constatado um total de 810 a 817 aulas de música ou com a temática associada a música conforme Tabela 2 a seguir. Esta apresenta a quantidade de "aulas" de música no Espaço da Aula, encontrados com a palavra-chave “música" na data de 09/2013, 03/2014 e 08/2015, no primeiro acesso, foi encontrado um total de 810 aulas de música e 93 coleções de aula de música.

Tabela 2 - Quantidade de aulas de música por período de busca

\begin{tabular}{cc}
\hline & Aulas de Música \\
\hline Aulas & Setembro de 2013 \\
Coleções de aulas & 810 \\
& 93 \\
\hline
\end{tabular}

Fonte: Dados da Pesquisa no Portal do Professor, organizada pela autora.

Conforme a Tabela 3, abaixo, é apresentada a soma resultante das aulas, compreendendo os níveis da: Educação Infantil com 129 aulas de música; Ensino Fundamental inicial com 359 aulas de música; Ensino Fundamental Final com 278 aulas de música; Ensino médio com 163 aulas de música; e Educação Profissional ${ }^{26}$ com 5 aulas de música. As modalidades apresentaram os seguintes resultados: Educação de Jovens e Adultos $1^{\circ}$ ciclo com 63 aulas de música; Educação de Jovens e Adultos $2^{\circ}$ ciclo com 189 aulas de música; e Educação Escolar Indígena com 23 aulas de música.

\footnotetext{
${ }^{26}$ No Portal do Professor do MEC a Educação Profissional é classificada como Nível educacional e não modalidade como classifica a LDBEN, ver Quadros 1 e 2 no Capítulo 2.2.1 desta Dissertação.
} 
Tabela 3 - "Tipo de Pesquisa" e Número de Aulas de Música

\begin{tabular}{|c|c|c|}
\hline Seleção por "Tipo de Pesquisa" & Tipo & Aulas de música \\
\hline \multirow{5}{*}{ Níveis } & Educação Infantil & 129 \\
\hline & $\begin{array}{c}\text { Ensino fundamental Inicial (6-9 } \\
\text { anos de idade) }\end{array}$ & 356 \\
\hline & $\begin{array}{c}\text { Ensino fundamental Final (10 - } 14 \\
\text { anos de idade) }\end{array}$ & 278 \\
\hline & $\begin{array}{c}\text { Ensino Médio (15 - } 18 \text { anos de } \\
\text { idade) }\end{array}$ & 163 \\
\hline & $\begin{array}{c}\text { Educação Profissional (15 - ... } \\
\text { anos de idade) }\end{array}$ & 5 \\
\hline \multirow{3}{*}{ Modalidade } & $\begin{array}{c}\text { Educação de Jovens e Adultos }-1^{\circ} \\
\text { Ciclo }\end{array}$ & 63 \\
\hline & $\begin{array}{c}\text { Educação de Jovens e Adultos }-2^{\circ} \\
\text { Ciclo }\end{array}$ & 109 \\
\hline & Educação Escolar Indígena & 23 \\
\hline
\end{tabular}

Fonte: Dados da Pesquisa no Portal do Professor, organizada pela autora.

A soma dos totais de aula de música encontrados na busca avançada "Tipo de Pesquisa", 1126 aulas, não corresponde ao total de aulas encontradas na busca simples, ou seja, 810 aulas. Isto porque há repetição de aulas entre os diferentes níveis e modalidades educacionais, ou seja uma mesma aula pode ser classificada para o Ensino Fundamental Final, para o Ensino Fundamental Inicial e para o Ensino Médio por exemplo. O total de aulas disponibilizadas no Portal, 810 ou 1126, é alto para a análise pretendida nesta pesquisa. Assim, foi necessário realizar uma seleção intencional de aulas que viabilizasse a análise. Nesse sentido, optou-se por uma seleção de aulas de música planejadas para o Ensino Fundamental Final, Ensino Médio, Ensino Profissional e Modalidade Educação de Jovens e Adultos (EJA) $2^{\circ}$ ciclo, que segundo a LDBEN 9394/96 (BRASIL, 1996) estão sob responsabilidade do professor licenciado em cursos de graduação em Licenciatura plena. Os níveis Educação Infantil e Ensino Fundamental Inicial apresentam maior número de aulas publicadas, contudo, eles são de responsabilidade do pedagogo. A Educação Escolar Indígena foi excluída porque apresenta Arte como componente curricular, mas não apresenta Tema relacionado com música nas opções de busca avançada do Portal.

Nessa nova busca foram utilizados os seguintes filtros: níveis/modalidade educacionais "Componente Curricular" 27 e seus respectivos temas.

No item seguinte é apresentada essa nova busca e seus resultados.

${ }^{27}$ A arte é um dos componentes curriculares obrigatórios da Educação Básica conforme determina o $§ 2^{\mathrm{o}}$ do Art. 26 da LDBEN 9394/96. Segundo a legislação a música é conteúdo obrigatório mas não exclusivo do componente curricular Arte (Lei n¹1.769 de 2008). 


\subsubsection{Segunda busca avançada e primeira seleção de aulas}

No segundo momento da pesquisa foi realizado um levantamento de aulas organizado por busca avançada utilizando a ferramenta "mais opções de busca": 1) "Tipo de busca", Níveis: Ensino Médio; Ensino Fundamental Final; Ensino Profissional e Modalidade: Educação de Jovens e Adultos - EJA, $2^{\circ}$ Ciclo; 2) "Componente Curricular", Artes ou seu equivalente no caso do Ensino Profissional e 3) "Tema", o elencado pelos PCN para cada Nível e Modalidade e adotado pelo Portal. Nos itens "UF e "Ordem de Classificação" da busca avançada foi utilizada a opção "todos" que não interfere no total de aulas e por isso não aparece na Tabela 4.

O "Tema", de acordo com nível/modalidade educacional selecionado, atendendo aos critérios curriculares do PCN para o Ensino Médio são: Música Canal; Música Contextualização; Música Estruturas sintáticas e Música Estruturas morfológicas. Para o Ensino Fundamental Final os temas são: Música Apreciação significativa em música: escuta, envolvimento e compreensão da linguagem musical; Música Compreensão da música como produto cultural e histórico e Música Expressão e comunicação em música: improvisação, composição e interpretação. No Ensino Profissional os temas definem a opção profissional: Técnico em Canto; Técnico em Composição e Arranjo; Técnico em Documentação Musical; Técnico em Fabricação de Instrumentos Musicais; e Técnico em Instrumento Musical. Para a Educação de Jovens e Adultos - EJA, $2^{\circ}$ Ciclo as temáticas são: Música: desenvolvimento da linguagem musical.

Ao efetivar essa segunda busca no Portal constatou-se alteração no total de aulas na busca simples, ou seja, em vez de 810 aulas, foi observado o valor de 813 aulas, 3 aulas a mais da quantidade de aulas verificadas na primeira busca, conforme Tabela 4. Contudo, o total de coleções de aula se manteve inalterado.

Tabela 4 - Quantidade de aulas de música por períodos de busca

\begin{tabular}{ccc}
\hline & Setembro de 2013 & Março de 2014 \\
Aulas & 810 & 813 \\
Coleções de aulas & 93 & 93 \\
\hline
\end{tabular}

Fonte: Dados da pesquisa no Portal do Professor, organizada pela autora. 
Os resultados do levantamento realizado na segunda busca são apresentados na Tabela 5. Nela é possível observar a quantidade de aulas para cada nível/modalidade, componente curricular e Tema. O total de aulas na busca avançada é maior que o total de aulas na busca simples, pois as aulas em cada nível educacional/modalidade se repetem nos Temas.

Tabela 5 - Quantidade de aulas de música por Nível /Modalidade e Tema do Componente curricular

\begin{tabular}{|c|c|c|c|c|c|c|}
\hline & & & Arte & & & \\
\hline & $\begin{array}{l}\text { Nível ou } \\
\text { Modalidade }\end{array}$ & $\begin{array}{l}\text { Componente } \\
\text { curricular }\end{array}$ & Tema & Aulas & $\begin{array}{c}\text { Total de } \\
\text { aulas } \\
\text { busca } \\
\text { avançada }\end{array}$ & $\begin{array}{c}\text { Total de } \\
\text { aulas na } \\
\text { busca } \\
\text { simples }\end{array}$ \\
\hline & & & $\begin{array}{l}\text { - Apreciação } \\
\text { significativa em } \\
\text { música: escuta, } \\
\text { envolvimento e } \\
\text { compreensão da } \\
\text { linguagem musical. }\end{array}$ & 139 & & \\
\hline & $\begin{array}{l}\text { fundamental Final } \\
\text { (10 - } 14 \text { anos de } \\
\text { idade })\end{array}$ & Artes & $\begin{array}{l}\text { - Compreensão da } \\
\text { música como produto } \\
\text { cultural e histórico. }\end{array}$ & 136 & 417 & $\mathrm{EF}=278$ \\
\hline & & & $\begin{array}{l}\text { - Expressão e } \\
\text { comunicação em } \\
\text { música: improvisação, } \\
\text { composição e } \\
\text { interpretação. }\end{array}$ & 142 & & \\
\hline Temas & & & - Canal & 117 & & \\
\hline educacionais & & & - Contextualização & 123 & & FM-162 \\
\hline & $\begin{array}{l}\text { Ensino Medio (15 } \\
-18 \text { anos de idade) }\end{array}$ & Artes & - Estruturas sintáticas & 101 & 443 & $E N=103$ \\
\hline & & & $\begin{array}{l}\text { - Estruturas } \\
\text { morfológicas }\end{array}$ & 102 & & \\
\hline & & & - Técnico em Canto & 1 & & \\
\hline & & & $\begin{array}{l}\text { - Técnico em } \\
\text { Composição e Arranjo }\end{array}$ & 5 & & \\
\hline & $\begin{array}{c}\text { Educação } \\
\text { Profissional (15 - }\end{array}$ & Produção & $\begin{array}{l}\text { - Técnico em } \\
\text { Documentação Musical }\end{array}$ & 5 & 20 & $\mathrm{FP}=5$ \\
\hline & $\ldots$ anos de idade) & Design & $\begin{array}{l}\text { - Técnico em } \\
\text { Fabricação de } \\
\text { Instrumentos Musicais }\end{array}$ & 4 & & \\
\hline & & & $\begin{array}{l}\text { - Técnico em } \\
\text { Instrumento Musical }\end{array}$ & 5 & & \\
\hline & $\begin{array}{l}\text { Educação de } \\
\text { Jovens e Adultos - } \\
\text { EJA } 2^{\circ} \text { Ciclo }\end{array}$ & Artes & $\begin{array}{c}\text { Música: } \\
\text { desenvolvimento da } \\
\text { linguagem musical }\end{array}$ & 109 & 109 & $\mathrm{EJA}=109$ \\
\hline & & tal de aulas & & & 989 & 555 \\
\hline
\end{tabular}

Fonte: Dados da pesquisa no Portal do Professor, organizada pela autora.

Diante da quantidade de aulas apresentadas (989 ou 555), realizou-se uma nova seleção intencional em que se optou pela análise das aulas do nível Ensino Médio. Isto porque 
esse nível educacional está diretamente relacionado a formação de professores no Ensino Superior e, no Portal do Professor, muitas das aulas criadas são planejadas para o Ensino Médio e também indicadas para os outros níveis/modalidades. Essa busca exigiu a definição de novos critérios para seleção de aulas, em que foram selecionadas as 10 primeiras aulas do Ensino Médio para cada "Ordem de Classificação" nas opções aulas: Mais comentadas; Melhor classificadas e Mais acessadas. Os resultados dessa busca foram organizados em um quadro de aulas/ordem de classificação por Tema (Canal, Estruturas Sintáticas, Estruturas Morfológicas, Contextualização) como mostra o Apêndice A. O quadro é organizado pelas 10 primeiras aulas apresentadas em cada ordem de classificação: mais comentadas, melhor classificadas e mais acessadas. Na organização das 10 aulas mais acessadas, 10 aulas melhor classificadas e 10 aulas mais comentadas por cada Tema, observou-se a repetição de aulas entre duas ou três ordem de classificação e entre os Temas (ver Apêndice A). Ao todo foram listadas 120 aulas com a repetição de 11 aulas entre as categorias de ordem de classificação e no mínimo de 3 Temas, encontrou-se 1 repetida entre todos os Temas, o que sugere um total de 119 aulas para o Ensino Médio entre as 10 primeiras por Tema/ordem de classificação. Optou-se então pela seleção intencional das aulas repetidas pelo menos em duas categorias (Tema ou ordem de classificação) do quadro do Apêndice A.

Os resultados das aulas repetidas, 11 e portanto, consideradas interessantes para a pesquisa, pode ser observado no Quadro 8 a seguir.

Quadro 7 - Amostragem das aulas repetidas na seleção intencional de aulas do Ensino Médio por tema e ordem de classificação a serem objeto de análise

\begin{tabular}{|c|c|c|c|}
\hline CANAL & CONTEXTULIZAÇÃO & $\begin{array}{l}\text { ESTRUTURAS } \\
\text { MORFOLÓGICAS }\end{array}$ & $\begin{array}{l}\text { ESTRUTURAS } \\
\text { SINTÁTICAS }\end{array}$ \\
\hline A ponte & & A ponte & A ponte \\
\hline $\begin{array}{l}\text { Música - Canto coletivo } \\
\text { na África do Sul (aula } \\
\text { 02): "Tchotcholôsa", um } \\
\text { canto de trabalho }\end{array}$ & $\begin{array}{l}\text { Música - Canto coletivo } \\
\text { na África do Sul (aula } \\
\text { 02): "Tchotcholôsa", um } \\
\text { canto de trabalho }\end{array}$ & $\begin{array}{l}\text { Música - Canto } \\
\text { coletivo na África do } \\
\text { Sul (aula 02): } \\
\text { "Tchotcholôsa", um } \\
\text { canto de trabalho }\end{array}$ & $\begin{array}{l}\text { Música - Canto coletivo na } \\
\text { África do Sul (aula 02): } \\
\text { "Tchotcholôsa", um canto de } \\
\text { trabalho }\end{array}$ \\
\hline $\begin{array}{l}\text { Conceitos de música: } \\
\text { ritmo, melodia e harmonia } \\
\text { - aula } 3\end{array}$ & & $\begin{array}{l}\text { Conceitos de música: } \\
\text { ritmo, melodia e } \\
\text { harmonia - aula } 3\end{array}$ & $\begin{array}{l}\text { Conceitos de música: ritmo, } \\
\text { melodia e harmonia - aula } 3\end{array}$ \\
\hline & & & $\begin{array}{l}\text { Literando: Carlos } \\
\text { Drummond de Andrade }\end{array}$ \\
\hline
\end{tabular}

Fonte: Dados da pesquisa no Portal do Professor. Organizado pela autora.

O trabalho de organização das aulas em uma listagem por Tema e ordem de classificação cumpriu a finalidade de conhecer os tipos e formatos de "Aula", 
disponibilizados no link ou página "Sugestões de Aula" da grande área "Espaço da Aula" do Portal. Das aulas organizadas no quadro do Apêndice A questionou-se qual a melhor seleção e qual a sua representatividade: 1) até que ponto a seleção das aulas repetidas em cada categoria, Tema/ordem de classificação é uma amostra representativa das aulas de música no Portal? 2) Até que ponto a seleção das 10 primeiras aulas de cada opção de Tema/ordem de classificação, com exclusão das aulas repetidas em casa categoria, é uma amostra representativa das aulas de música no Portal? 3) Esse critério de seleção possibilita a todas as aulas de música disponibilizadas no "Espaço da Aula" terem a mesma oportunidade de serem selecionadas como amostra a ser analisada?

A partir dessa reflexão, conclui-se que a seleção intencional das XXX aulas repetidas ou das XXX aulas não repetidas poderiam não caracterizar as aulas disponibilizadas no portal, o que levou a definição de novo critério de seleção.

Assim, realizou-se um processo de seleção aleatória das aulas disponibilizadas no Portal para que todas pudessem participar da análise. Nesse sentido, foi realizado um processo de amostragem por sorteio a ser explicado no tópico seguinte.

\subsubsection{Seleção de aulas por meio de amostragem aleatória}

Neste terceiro momento, seleção de aulas por meio de amostragem aleatória foram executadas as seguintes fases: 1) sorteio aleatório de um número entre 1 a 9 para orientar a sequência de seleção de aulas selecionadas 2) sorteio do número inicial entre 1 a 9 para iniciar a sequência de seleção de aulas; 3) organização das aulas selecionadas; 4) exclusão das aulas repetidas. A seleção foi realizada na opção "mais opção de busca" no Portal pela opção Música, Ensino Médio, e ordem de classificação "mais acessadas".

A partir desse momento, deu-se início a uma amostragem probabilística. Atendeu-se a descrição de Babbie (2005), que se refere a esse tipo de amostragem como: "uma amostra será representativa da população da qual foi selecionada se todos os membros da população tiverem oportunidade igual de serem selecionados para a amostra." (BABBIE, 2005, p.120).

\subsubsection{Seleção com sorteio aleatório e número inicial por sorteio}


Essa seleção aconteceu em três fases. Visando maior organização e grau de representatividade, na primeira fase, selecionou-se uma amostragem probabilística intencional. Para esse procedimento, realizou-se uma listagem de aulas utilizando a busca avançada na opção "mais opções de busca", item "Tipo de busca": Nível: Ensino Médio; No item "ordem de classificação" optou-se pela categoria "mais acessadas", por considerar que as aulas mais acessadas são referência e têm sido replicadas, modificadas e comentadas pelos usuários.

$\mathrm{Na}$ segunda fase da amostragem, realizou-se a listagem de todas as aulas pelo seu título e ordem de apresentação no resultado da busca.

Seguidamente, na terceira fase, tendo a listagem de todas as aulas publicadas para o Nível Médio, procedeu-se a seleção sistemática com sorteio aleatório de um número entre 1 a 9 como fator de intervalo entre duas aulas selecionadas. O número sorteado foi o número 7. Para definir o número da aula que iniciaria a contagem e seleção de aulas, foi realizado um novo sorteio entre 1 a 9 e o resultado foi o número 5. Assim, a seleção de aulas iniciaria com o número 5, a quinta aula mais acessada, e a segunda aula, segundo o intervalo de 7 aulas, seria a de número 12 e assim por diante.

As aulas selecionadas foram organizadas conforme explicitado no item seguinte.

\subsubsection{Organização de aulas selecionadas}

A etapa seguinte correspondeu à organização das aulas selecionadas na fase anterior em um quadro que identifica a aula numa sequência numeral, o autor ${ }^{28}$ e o título das aulas (Quadro 9), considerando o número total de aulas de música selecionadas $(\mathrm{N}=48)$ para o Ensino médio de um universo de 443 aulas apresentadas na busca avançada.

Cada uma das 48 aulas foi copiada em arquivo digital na ordem descrita no quadro, respeitando a ordem de seleção por sorteio e, de igual maneira, foi impressa, para posterior, organização em caderno de aulas de música, com o número da aula e a numeração das páginas.

\footnotetext{
${ }^{28}$ Os nomes reais dos autores foram substituídos pelo código AT e um número identificando a ordem de apresentação da autoria na seleção de aulas "mais acessadas".
} 
No capítulo dedicado à interpretação dos resultados se aprofunda a análise do resultado do Quadro 9, em que são observados os autores e coautores das aulas que se repetem em diferentes aulas.

Quadro 8 - Organização da amostra de aulas por $\mathrm{N}^{\circ}$ sequencial de seleção, Autor e Título.

\begin{tabular}{|c|c|c|}
\hline $\begin{array}{c}\mathbf{N}^{\circ} \text { de } \\
\text { aula }\end{array}$ & AUTOR & TITULO \\
\hline 1 & AT 1 & $\begin{array}{l}\text { Música - Canto coletivo na África do Sul (aula 02): "Tchotcholôsa”, um } \\
\text { canto de trabalho }\end{array}$ \\
\hline 2 & AT 2 & Música para quê? \\
\hline 3 & AT 3 & MÚSICA - Percussão corporal: Mãos \\
\hline 4 & AT 3 & MÚSICA - escrita e leitura musical: compasso (aula 2) \\
\hline 5 & AT 2 & A ponte \\
\hline 6 & AT 3 & MÚSICA - Percussão corporal: Composição (aula 1) \\
\hline 7 & AT 2 & Uma orquestra diferente \\
\hline 8 & AT 3 & MÚSICA - escrita e leitura musical: dominó com figuras musicais (aula 3). \\
\hline 9 & AT 3 & MÚSICA: Construção de instrumento musical - violão de caixa de sapato \\
\hline 10 & AT 4 & Tropicália: música, comportamento e atitude no Brasil da década de 1960 \\
\hline 11 & AT 3 & MÚSICA - Percussão corporal: Boca \\
\hline 12 & AT 5 & $\begin{array}{l}\text { Música - Jogos musicais com percussão corporal: percepção de ritmo - aula } \\
4\end{array}$ \\
\hline 13 & AT 6 & O Funk carioca e sua dinâmica social \\
\hline 14 & AT 7 & Música - Trilha sonora - Projeto e Roteiro \\
\hline 15 & AT 3 & MÚSICA- Oficina 3: paisagem sonora. \\
\hline 16 & AT 3 & MÚSICA - Oficina 4 - $\mathrm{O}$ universo do DJ \\
\hline 17 & AT 3 & MÚSICA - Percussão corporal: Composição (aula 2) \\
\hline 18 & AT 1 & $\begin{array}{l}\text { Música - Gumboot Dancing, dança de resistência das minas da África do } \\
\text { Sul - aula } 01\end{array}$ \\
\hline 19 & AT 7 & Música - criação de canção: ritmo e gênero \\
\hline 20 & AT 3 & MÚSICA: Elementos de expressão (andamento) - accelerando e rallentando \\
\hline 21 & AT 3 & MÚSICA: Composição - Frase \\
\hline 22 & AT 7 & Música - Criação de canção - "Estudando o samba" (parte 2) \\
\hline 23 & AT 3 & MÚSICA: Composição - Elementos de Contraste \\
\hline 24 & AT 1 & $\begin{array}{l}\text { Música - Pedal e Ostinato, uma experiência de composição com alunos em } \\
\text { sala de aula - aula } 02\end{array}$ \\
\hline 25 & AT 7 & Música - criação de canção: conceito - aula 1 \\
\hline 26 & AT 7 & Música - criação de canção: relação entre texto, melodia e lí \\
\hline 27 & AT 2 & O Tom do Samba \\
\hline 28 & AT 8 & Dança de Salão: Introdução ao Forró \\
\hline 29 & AT 9 & Música - Matemúsicas - Tempo \\
\hline 30 & AT 9 & Música - Composição Imagística (parte 1) \\
\hline 31 & AT 7 & Música - criação de canção: tema e forma \\
\hline 32 & AT 9 & Música - Matemúsicas - Matriz (parte 2 \\
\hline 33 & AT 9 & Música - Matemúsicas - Altura \\
\hline 34 & AT 3 & MÚSICA: Composição - Objeto Sonoro e Música Concreta \\
\hline 35 & AT 1 & $\begin{array}{l}\text { Música - Pedal e Ostinato, uma experiência de composição com alunos em } \\
\text { sala de aula - aula } 05\end{array}$ \\
\hline 36 & AT 1 & $\begin{array}{l}\text { Música - Pedal e Ostinato, uma experiência de composição com alunos em } \\
\text { sala de aula - aula } 04\end{array}$ \\
\hline 37 & AT 9 & Música - Recepção, gosto e identidade - segunda parte (aula 5 \\
\hline 38 & AT 3 & MÚSICA: Composição - Improvisação \\
\hline 39 & AT 9 & Música - compassos ternários - Leitura e escrita 3 \\
\hline
\end{tabular}




\begin{tabular}{|c|c|l|}
\hline $\mathbf{4 0}$ & AT 9 & Música - Composição Imagística (parte 5) \\
\hline $\mathbf{4 1}$ & AT 3 & MúSICA: Composição - Aleatoriedade \\
\hline $\mathbf{4 2}$ & AT 1 & $\begin{array}{l}\text { Música - O computador como instrumento musical (aula 2): Audacity, o } \\
\text { início }\end{array}$ \\
\hline $\mathbf{4 3}$ & AT 9 & Música - compassos quaternários - Leitura e escrita 1 \\
\hline $\mathbf{4 4}$ & AT 9 & Música - compassos quaternários - Leitura e escrita 6 \\
\hline $\mathbf{4 5}$ & AT 8 & Dança de salão: Introdução ao Samba \\
\hline $\mathbf{4 6}$ & AT 9 & Música - Expressividade - Contraste (parte 2) \\
\hline $\mathbf{4 7}$ & AT 9 & Música - compassos quaternários - Leitura e escrita 2 \\
\hline $\mathbf{4 8}$ & AT 9 & Música - compassos ternários - Leitura e escrita 2 \\
\hline Fonte: Autora - Dados da Pesquisa. Organizado pela autora.
\end{tabular}

Nessa seleção final ( $\mathrm{N}=48)$, considerou-se que todas as aulas do Ensino Médio tiveram a mesma chance de seleção.

Nos momentos seguintes foram realizados os seguintes procedimentos: 4) organização das aulas em tabelas e gráficos; 5) categorização das aulas do Portal e 6) interpretação quantitativa e qualitativa dos dados.

Os resultados dessa análise serão apresentados no tópico seguinte dedicado aos procedimentos de análise das aulas.

\subsection{PROCEDIMENTOS DE ANÁLISE DAS AULAS}

Neste tópico, são descritos os momentos anteriormente mencionados no item "Seleção de aulas por meio de amostragem aleatória". Continuando a numeração: 4) organização das aulas em tabelas e gráficos; 5) categorização das aulas do Portal; 6) interpretação quantitativa e qualitativa dos dados.

O nível educacional escolhido para a análise das aulas é o Ensino Médio por ter relação direta com a formação na Licenciatura como já dito. Cabe lembrar que os níveis de Ensino Profissional e Ensino Fundamental II apresentaram resultados de aulas que se repetem no nível de Ensino Médio e por isso foram desconsiderados. A questão da sugestão de uma mesma aula para diferentes níveis de escolaridade pode ser discussão em outra pesquisa.

\subsubsection{Organização das aulas em tabelas e gráficos e análise de amostra intencional}

A organização das 48 aulas da amostragem aleatória foi feita, primeiramente, em um quadro geral disponibilizado no Apêndice B. Este apresenta o número sequencial de aulas 
disponibilizadas no Portal e o Tema que diz respeito ao Componente Curricular Artes. Os Temas têm relação com os elementos básicos do processo da comunicação: código (estruturas morfológicas e estruturas sintáticas), canal e contexto, descritos para cada área em “Linguagens, Códigos e suas Tecnologias" (OCNEM, 1996, p. 167).

Foram excluídas as aulas que se repetiram nos diferentes temas (ver Apêndice B).

A soma resultante de aulas para cada Tema foi: Música: Canal 14 aulas; Música: Contextualização 11 aulas; Música: Estruturas sintáticas 14 aulas; Música: Estruturas morfológicas 9 aulas. O total de aulas para ser analisadas correspondeu a 48.

Quadro 9 - Aulas amostra intencional aleatória por sorteio

\begin{tabular}{|c|c|c|c|c|}
\hline \multirow{3}{*}{$\begin{array}{c}\text { Total de Aulas de } \\
\text { música }\end{array}$} & \multicolumn{4}{|c|}{ Tema } \\
\hline & CANAL & CONTEXTUALIZAÇÃO & $\begin{array}{l}\text { ESTRUTURAS } \\
\text { SINTÁTICAS }\end{array}$ & $\begin{array}{l}\text { ESTRUTURAS } \\
\text { MORFOLÓGICAS }\end{array}$ \\
\hline & 117 & 123 & 101 & 102 \\
\hline $\begin{array}{l}\text { Total: amostragem } \\
\text { aleatória. }\end{array}$ & 17 & 17 & 14 & 14 \\
\hline $\begin{array}{l}\text { Total: seleção } \\
\text { amostragem } \\
\text { aleatória }\end{array}$ & $\begin{array}{c}14 \\
\text { Aulas }\end{array}$ & 11 Aulas & 14 Aulas & 9 Aulas \\
\hline Total: & & & 3 Aulas & \\
\hline
\end{tabular}

Fonte: Autora - Dados da pesquisa no Portal do Professor. Organizado pela autora.

Com total de 48 aulas selecionadas aleatoriamente, procedeu-se com a impressão de cada uma das 48 aulas de música organizando-as pela ordem de contagem do quadro referido, isto visando a análise detalhada.

\subsubsection{Categorização das aulas do Portal}

Este passo teve duas faces: quantitativa e qualitativa, foram realizadas em vários momentos de forma simultânea e intercalada de modo a complementar a informação, a análise e a sua interpretação.

Procedeu-se com a realização de duas planilhas: uma, contém os Componentes de publicação da aula apresentada pelo Portal, identificados por "Campos fixos" e aqui por "Planilha de Base 1" (PB1); a segunda planilha com os componentes identificados no Portal como "Campos abertos", e aqui denominada "Planilha e Base 2" (PB2), a qual contém Categorização de acordo com os dados emergentes do planejamento das aulas. 
A primeira planilha, PB1, foi organizada para as 48 aulas resultantes da seleção na amostragem aleatória por sorteio. Diz respeito aos elementos da apresentação da aula no Portal e contém: 1) número de aula de seleção; 2) título da aula; 3) autor e coautor da aula, quando houve; 4) instituição; 5) Nível ou Modalidade de ensino da aula; 6) Componente curricular da aula; 7) Tema da aula; 8) Conhecimentos prévios; 9) Duração da aula; e acrescentou-se depois o ano da publicação.

Adotaram-se nessa Planilha siglas para indicar os níveis e modalidades de ensino, estes explicitados na segunda linha do quadro 11. Neste são apresentadas os elementos de apresentação das aulas no Portal, categorias prévias de análise sendo o quadro completo apresentado no Apêndice C:

Quadro 10 - Parâmetros de análise- planilha de elementos de disponibilização de aula (Apêndice C)

\begin{tabular}{|c|c|c|c|c|c|c|c|c|c|}
\hline \multicolumn{10}{|c|}{ Planilha B1 - AULAS DO PORTAL DO PROFESSOR } \\
\hline \multicolumn{10}{|c|}{$\begin{array}{l}\text { EM=ensino Médio; EFF=Ensino Fundamental Final; EFI=Ensino Fundamental Inicial; EJA= Educação de } \\
\text { Jovens e Adultos - } 2^{\circ} \text { ciclo, Ed Prof=Educação Profissional; EEI=Educação Escolar Indígena }\end{array}$} \\
\hline $\begin{array}{c}\mathrm{N}^{\circ} \\
\text { aula }\end{array}$ & Título & Autor & Instituição & $\begin{array}{l}\text { Modalidade } \\
\text { Nível de } \\
\text { Ensino }\end{array}$ & $\begin{array}{l}\text { Componente } \\
\text { Curricular }\end{array}$ & Tema & $\begin{array}{l}\text { Conhecimento } \\
\text { Prévios }\end{array}$ & Duração & Ano \\
\hline
\end{tabular}

Fonte: Autora - Dados da pesquisa no Portal do Professor. Organizado pela autora.

A segunda planilha, PB2, diz respeito às Categorias emergentes de análise das aulas, elas são os componentes da gestão do conteúdo no planejamento das aulas: 1) Objetivos; 2) Estratégias; 3) Recursos; e 4) Avaliação. As categorias são apresentadas no quadro 12 abaixo e o quadro completo é apresentado no Apêndice D:

Quadro 11 - Parâmetros de análise - categorias (Apêndice D)

\begin{tabular}{|c|c|c|c|c|c|c|c|c|c|}
\hline \multirow[b]{2}{*}{$\frac{\pi}{3}$} & \multicolumn{2}{|c|}{ Objetivos } & \multicolumn{2}{|c|}{ Estratégias } & \multicolumn{2}{|c|}{ Recursos } & \multicolumn{3}{|c|}{ Avaliação } \\
\hline & $\begin{array}{l}\text { Descri- } \\
\text { ção / } \\
\text { Ação }\end{array}$ & $\begin{array}{c}\text { Foco } \\
\text { (centrada } \\
\text { no aluno, } \\
\text { no profes- } \\
\text { sor ou no } \\
\text { conteúdo) }\end{array}$ & $\begin{array}{c}\text { Atividades } \\
\text { (tipo, } \\
\text { natureza, } \\
\text { Ação do } \\
\text { professor, } \\
\text { Ação do } \\
\text { estudante). }\end{array}$ & $\begin{array}{c}\text { Sequenc } \\
\text { ia } \\
\text { didática }\end{array}$ & $\begin{array}{c}\text { Ferramen- } \\
\text { tas } \\
\text { didáticas }\end{array}$ & $\begin{array}{l}\text { Multi- } \\
\text { mídia }\end{array}$ & Relação & $\begin{array}{l}\text { Instru- } \\
\text { mentos }\end{array}$ & Tipo \\
\hline
\end{tabular}

Fonte: Autora - Dados da pesquisa no Portal do Professor. Organizado pela autora. 
Tendo como base a planilha dos componentes da publicação da aula no Portal (PB1), para fornecer apoio, referência prévia e complemento; procedeu-se à análise da Planilha que contém as categorias de acordo aos dados emergentes do planejamento das aulas (PB2). Cada uma das categorias foi organizada com duas subcategorias para efeitos de orientação e esclarecimentos na análise. A seguir detalham-se as categorias descritas acima:

Categoria Objetivos, para esta, foram analisadas as subcategorias: Descrição; Ação; e Foco (centrada no aluno, no professor ou no conteúdo). Realizou-se essa subdivisão como complemento para algumas aulas de música disponibilizadas no Portal que apresentam Descrição explicativa de objetivos, esclarecendo o seu caráter interdisciplinar ou de contexto social. Foco, diz respeito ao eixo da aula centrada no aluno, no professor ou no conteúdo. A Ação faz relação aos verbos utilizados pelo autor, o Portal sugere o uso de verbos de ação para indicar com precisão quanto as mudanças e aprendizagens que se esperam que aconteçam a partir da aula e pede para que esses sejam escritos no infinitivo e que indiquem comportamentos que possam ser avaliados, como observado na seguinte citação:

O objetivo de uma aula deve indicar claramente o que é esperado do aluno. Quais mudanças nós esperamos que aconteçam a partir de nossa aula? O que exatamente o aluno poderá aprender? Um objetivo educacional deve indicar um comportamento passível de avaliação. ... Ao enviar o planejamento de uma aula, liste os objetivos com verbos de ação no infinitivo e que indiquem precisão. (Portal do Professor, Dicas para elaboração de aulas, p. 6).

A categoria Estratégias contêm as subcategorias Atividades e Sequência Didática. Sendo que as Atividades se referem ao tipo, se for entre outras, sinestésica, de prática instrumental, de apreciação musical, composição ou de letramento; à natureza, referindo-se ao conteúdo conceitual, procedimental ou atitudinal; e à ação do professor e do estudante.

Para a categoria Recursos apresenta-se a distinção entre Ferramentas didáticas e Multimídia. A primeira referida a materiais convencionais como quadro, folhas de papel, instrumentos musicais, acessórios de gravação e de audição. Multimídia referindo-se às NTICs.

A categoria Avaliação, dividiu-se em: Relação, ao respeito das relações com objetivos, conteúdos, atividades. Instrumentos, ao respeito das técnicas e recursos empregados. E, Tipo, se for somativa ou formativa. 


\subsubsection{Interpretações quantitativa e qualitativa dos dados}

A interpretação das aulas realizou-se de acordo aos dados levantados nas planilhas anteriormente mencionadas: PB1 e PB2; e a vinculação com aporte teórico apresentado neste trabalho.

As informações e dados da pesquisa não usam os nomes reais assim como apresentados nas aulas disponibilizadas pelo Portal do Professor, mesmo em se tratando de REA, um recurso cuja principal característica é a licença aberta. As informações referem-se a: nomes dos autores das aulas como "AT"; coautores "CAT"; instituições às que os autores e coautores estão vinculados; e título das aulas de música. 


\section{AS AULAS DE MÚSICA NO "ESPAÇO DA AULA": INTERPRETAÇÃO E RESULTADOS}

A análise quanti-qualitativa das aulas categorizou e analisou 20 aulas de música do total de 48 aulas da amostragem do nível Ensino Médio apresentadas e descritas na Planilha PB2 anteriormente mencionada e referente às categorias dos "Campos abertos".

Para a análise quantitativa foram analisadas o total das 48 aulas de Ensino Médio selecionadas na amostragem aleatória por sorteio, quando foram observadas e analisadas as nove categorias descritas anteriormente, na planilha PB1 referente aos componentes da publicação ou "campos fixos" da aula.

\subsection{AUTORES}

A autoria no Portal diz respeito ao criador da aula, com a possibilidade de criação de aulas individualmente ou em grupo. Como já dito, para se criar uma aula, o autor pode ser um professor ou um aluno de licenciatura, a exigência do Portal é que quem crie a aula esteja cadastrado no Portal.

Coautor é uma opção do Portal para se criar uma aula em parceria.

Foram analisados os autores e coautores das aulas de música selecionadas. Se analisa a frequência de participação dos mesmos na publicação de aulas de música.

A autoria no quadro abaixo apresenta os autores (AT), criadores das 48 aulas analisadas; são quantificadas o número de aulas; apresenta-se a relação entre o autor, localidade onde cada autor exerce a atividade profissional e o período de 2009 a 2012 quando cada um realizou as publicações de suas aulas.

Quadro 12 - Quantidade de aulas por autor (AT), Estado e data de publicação - N=48 aulas

\begin{tabular}{|c|c|c|c|c|c|c|c|c|}
\hline \multirow{2}{*}{ Autor } & \multirow{2}{*}{$\begin{array}{l}\mathbf{N}^{\circ} \text { de } \\
\text { Aulas }\end{array}$} & \multicolumn{3}{|c|}{ Local (Unidade Federativa) } & \multicolumn{4}{|c|}{ Data } \\
\hline & & RJ & PR & MG & 2009 & 2010 & 2011 & 2012 \\
\hline AT 1 & 6 & 6 & - & - & 3 & 3 & - & - \\
\hline AT 2 & 4 & - & 4 & - & 3 & - & - & 1 \\
\hline AT 3 & 15 & 15 & - & - & 4 & 11 & - & - \\
\hline AT 4 & 1 & - & - & 1 & - & - & 1 & - \\
\hline AT 5 & 1 & 1 & - & - & - & - & 1 & - \\
\hline AT 6 & 1 & - & - & 1 & - & - & 1 & - \\
\hline
\end{tabular}


Continuação Quadro 13 - Quantidade de aulas por autor (AT), Estado e data de publicação - N=48 aulas

\begin{tabular}{|c|c|c|c|c|c|c|c|c|}
\hline \multirow{2}{*}{ Autor } & \multirow{2}{*}{$\begin{array}{l}\mathbf{N}^{\circ} \text { de } \\
\text { Aulas }\end{array}$} & \multicolumn{3}{|c|}{ Local (Unidade Federativa) } & \multicolumn{4}{|c|}{ Data } \\
\hline & & RJ & PR & MG & 2009 & 2010 & 2011 & 2012 \\
\hline AT 7 & 6 & 6 & - & - & - & 4 & 2 & - \\
\hline AT 8 & 2 & - & - & 2 & - & - & 1 & 1 \\
\hline AT 9 & 12 & 12 & - & - & 1 & 11 & - & - \\
\hline \multirow{2}{*}{ TOTAL } & \multirow{2}{*}{$\mathrm{N}=48$} & 40 & 4 & 4 & 11 & 29 & 6 & 2 \\
\hline & & & $\mathrm{N}=48$ & & \multicolumn{4}{|c|}{$\mathrm{N}=48$} \\
\hline
\end{tabular}

Fonte: Autora - dados da pesquisa. Organizado pela autora.

Nos resultados observa-se um baixo índice de autoria, a quantidade total de criadores de aula dentre as 48 aulas analisadas foi de 9 autores, com um máximo de 15 aulas e um mínimo de 1 aula produzidas por um único autor. $\mathrm{O}$ universo total $(\mathrm{N}=48)$ de aulas com 9 autores equivalem a uma média de 5,33 aulas por autor, contudo, as aulas estão distribuídas de forma desigual, há autores com 1 aula e autor com 15 aulas. Sendo 40 aulas dos mesmos autores.

Quanto ao Estado de origem das instituições dos autores, percebe-se a concentração da produção de aulas nas três cidades: do Rio de Janeiro-RJ; do Paraná-PR; e de Minas GeraisMG.

Observa-se pelo quadro acima que o ano de maior produção de aulas foi 2010.

A seguir apresentam-se com base nos resultados de autoria no quadro anterior, aqueles autores que apresentaram coautoria. Das 48 aulas de música analisadas somente uma aula não apresenta coautoria sendo essa a aula $\mathrm{N}^{\circ}$ 29, "Música - Matemúsicas - Tempo" do autor descrito nesta análise pelo código AT 9 (Caderno de aulas, p. 94 - 96).

Quadro 14 - Quantidade de aulas com coautoria por autor

\begin{tabular}{|c|c|}
\hline Autor & Aulas com Coautor \\
\hline AT 1 & 6 aulas \\
\hline AT 2 & 4 aulas \\
\hline AT 3 & 15 aulas \\
\hline AT 4 & 1 aulas \\
\hline AT 5 & 1 aulas \\
\hline AT 6 & 1 aulas \\
\hline AT 7 & 6 aulas \\
\hline AT 8 & 2 aulas \\
\hline AT 9 & 11 aulas \\
\hline Total aulas com coautor & $\mathbf{N = 4 7}$ \\
\hline
\end{tabular}

Fonte: Autora - dados da pesquisa. Organizado pela autora. 
O resultado da análise mostra a quantidade de 5 coautores participantes do universo total $\mathrm{N}=48$ aulas.

Nas aulas de música analisadas foram identificados coautores atuando em parceria com diferentes autores, no entanto, um dos autores se apresenta também como coautor, como observado nas aulas do autor AT 9 quem tem CAT 1 como coautor, contudo, o autor AT 3 é coautor em outras aulas como apresentado na aula $\mathrm{N}^{\circ} 12$ "Música - Jogos musicais com percussão corporal: percepção de ritmo - aula 4" do autor AT 5 (Caderno de aulas, p. 40 43).

O seguinte quadro apresenta a frequência de coautor por aulas resultando em 47 aulas com coautor.

\begin{tabular}{|c|c|}
\multicolumn{2}{|c|}{ Quadro 15 - Frequência de coautor ${ }^{29}$ por aulas } \\
\hline Coautor & $\mathbf{N}^{\circ}$ de aulas \\
\hline CAT 1 & 34 aulas \\
\hline CAT 2 & 4 aulas \\
\hline CAT 3 & 5 aulas \\
\hline CAT 4 & 2 aulas \\
\hline CAT 5 & 2 aulas \\
\hline Total aulas com coautor & $\mathbf{N = 4 7}$ \\
\hline
\end{tabular}

Fonte: Autora - dados da pesquisa. Organizado pela autora.

Dentre os 5 coautores somente CAT 1 é coautor em 34 aulas para um mesmo coautor e o segundo maior número de aulas por coautor é igual a 5 (AT 5), o que demostra a grande diferença entre os dois coautores que mais publicaram aulas.

Uma análise quantitativa de número de aulas com coautoria por autor é apresentada nas 6 aulas do autor AT 1.

Nessa análise se demostra como o coautor CAT 1 participa em todas as 6 aulas do autor AT 1 acima mencionado. A seguir a relação da participação do CAT 1: aula $\mathrm{N}^{\circ} 1$ "Música - Canto coletivo na África do Sul (aula 02): "Tchotcholôsa", um canto de trabalho"; aula N 18 "Música - Gumboot Dancing, dança de resistência das minas da África do Sul aula 01"; aula N²4 "Música - Pedal e Ostinato, uma experiência de composição com alunos em sala de aula - aula 02"; aula N³5 "Música - Pedal e Ostinato, uma experiência de composição com alunos em sala de aula - aula 05"; aula N³6 "Música - Pedal e Ostinato, uma experiência de composição com alunos em sala de aula - aula 04"; e aula N42 "Música -

\footnotetext{
${ }^{29}$ Os nomes reais dos coautores foram substituídos pelo código CAT.
} 
O computador como instrumento musical (aula 2): Audacity, o início", esta última apresentando como segundo autor AT 3.

É interessante também observar que a repetição de coautoria em várias aulas e a participação de autor como coautor indicam a colaboração e a parceria entre autores e coautores.

Diante dos dados questiona-se: o baixo índice de autoria poderia indicar desinteresse por parte do Portal para estimulo à participação de novos autores? A desigualdade na quantidade de aulas por autor poderia indicar falta de interesse dos autores que tem menor quantidade de aulas? Ou falta de interesse de outros autores que ou não criaram aulas ou não aprovaram suas aulas perante o comité avaliador do Portal? O fato de encontrar dentre as 48 aulas analisadas só 1 aula sem coautoria indica a preferencia dos autores pelo trabalho colaborativo? O fato de uma maioria de aulas com coautor poderia se explicar pela insegurança de se criar aulas individualmente? Ou pela colaboração entre formadores de professores e licenciandos ou professores em formação? O CAT 1 quem tem participação em 34 das 48 aulas analisadas é o "detentor" de todo o saber de ensino e aprendizagem da música? Ou o "detentor" da manipulação técnica digital quanto ao bom uso das NTICs no Portal? Ou o CAT cumpre a função de assessor ou consultor por Estado como representante do Portal?

A questões levantadas acima e não respondidas demonstram a baixa adesão de instituições e profissionais ao REA - Portal do Professor e o motivos para esse fato podem estar relacionados a: 1) falta de divulgação do Portal entre profissionais de música; 2) dificuldades com as normas e exigências do Portal para a criação de aulas e 3) dificuldade com a tecnologia para submissão de aulas. Essas questões podem ser aprofundadas em outra investigação que envolvesse tanto entrevistas com os autores e coautores como também questionários ou entrevistas com os usuários do Portal

\subsection{INSTITUIÇÃO}

No Portal, todo autor e coautor deve indicar a instituição a que está vinculado, o quadro 16 abaixo mostra a relação entre a instituição de atuação do autor da aula e o número de aulas publicadas. Nele são identificadas 2 instituições ligadas ao Ensino Médio; outras 3 ligadas ao Ensino Fundamental e 1 ligada ao Departamento de Educação. 
Quadro 16 - Quantidade de aulas por autor

\begin{tabular}{|c|c|c|c|c|c|}
\hline \multirow{4}{*}{ Aulas } & \multicolumn{5}{|c|}{ Instituição } \\
\hline & \multicolumn{2}{|c|}{ Colégio de Aplicação } & \multirow{2}{*}{$\begin{array}{c}\text { Secretaria Estadual } \\
\text { PR }\end{array}$} & \multirow{2}{*}{$\begin{array}{c}\text { Escola Municipal } \\
\text { RJ }\end{array}$} & \multirow[t]{2}{*}{ UFMG } \\
\hline & UFRJ & Juiz de Fora & & & \\
\hline & 25 & 2 & 4 & 15 & 2 \\
\hline Total & \multicolumn{5}{|c|}{$N=48$} \\
\hline
\end{tabular}

Fonte: Autora - dados da pesquisa. Organizado pela autora.

Nos resultados mostram que nas 48 aulas analisadas a participação institucional tem a quantidade de 6 instituições às que os autores estão filiados.

O Colégio de Aplicação de Rio de Janeiro detém o maior número de aulas com 25 publicações.

Dentre as instituições, somente a Universidade Federal de Minas Gerais - UFMG é uma instituição de Ensino Superior; o Colégio de Aplicação da Universidade Federal do Rio de Janeiro - UFRJ e da Universidade Federal de Juiz de Fora são instituições de ensino fundamental e médio vinculadas a IES; e as outras instituições citadas, Secretaria Estadual PR e Escola Municipal - RJ, são instituições de gestão educacional e de Ensino Fundamental e de Ensino Médio.

Confirma-se maior número de publicações de aulas nas regiões Sul e Sudeste.

De acordo aos resultados dessa análise, pode-se inferir que a participação dos três Estados que detém a criação de aulas no Portal indica um maior compromisso desses com a formação de professores, como também, pode sugerir carência de instituições formadoras de professores nos demais estados brasileiros ou falta de interesse das demais instituições educacionais brasileiras na participação no Portal.

A maioria da quantidade de aulas publicadas pelo Estado do RJ, 25 aulas de música, poderia, por exemplo, indicar falta de divulgação do Portal nos outros estados ou problemas de acesso ao Portal? As exigências de publicação de aulas no Portal podem influenciar ou estar em desacordo com as concepções de aulas de música dos profissionais da área? Ou as facilidades de acessibilidade no Estado e o domínio tecnológico dos profissionais pode explicar a maioria de aulas criadas?

Para uma análise mais aprofundada da questão os dados desta pesquisa podem ser comparados com os de outras áreas do conhecimento, como também ser aprofundados em outras pesquisas. 


\subsection{OBJETIVOS}

A definição de objetivo que o Portal fornece na aba "Orientações" da grande área "Espaço da Aula" é: “Objetivo é o que se espera que os alunos aprendam em determinadas condições de ensino. Os objetivos devem expressar exatamente o que se pretende que o aluno aprenda.” (PORTAL DO PROFESSOR, “Como criar uma aula”, p.5).

Os objetivos das aulas são descritos no componente do planejamento da aula reservado à questão: “O que o aluno poderá aprender com esta aula?”.

O Portal sugere aos autores das aulas que os objetivos sejam expressos por verbos de ação no infinitivo. Ainda atenta para a importância de se desenvolver "habilidades cognitivas mais complexas do que as exploradas tradicionalmente." (PORTAL DO PROFESSOR, "Reflexões pedagógicas", p.2) ${ }^{30}$, essa sugestão é também fornecida para o planejamento das estratégias e recursos. Pede-se ainda na página "Dicas para elaboração de aulas" que os objetivos respondam a pergunta acima mencionada "O que o aluno poderá aprender com esta aula" atentando para que as respostas sejam as competências elencadas pelo autor.

Para melhor entendimento do significado de competências e habilidades, a seguinte citação define:

Competências são as modalidades estruturais da inteligência, ou melhor, ações e operações que utilizamos para estabelecer relações com e entre objetos, situações, fenômenos e pessoas que desejamos conhecer. As habilidades decorrem das competências adquiridas e referem-se ao plano imediato do "saber fazer". Por meio das ações e operações, as habilidades aperfeiçoam-se e articulam-se, possibilitando nova reorganização das competências. (INEP, 2000, p. 5).

O Documento PCN+ esclarece que a "habilidade é uma competência específica" $(\mathrm{PCN}+$, p.16).

$\mathrm{O}$ atendimento à sugestão expressa pelo Portal observa-se, por exemplo, a seguir nos objetivos da aula $\mathrm{N}^{\circ} 3, \mathrm{~N}^{\circ} 7$ e $\mathrm{N}^{\circ} 19$. Nelas os autores usam os verbos para desenvolver habilidades. Na aula No 3, "MÚSICA - Percussão corporal: Mãos":

1. Explorar o conceito de percussão corporal utilizando as palmas das mãos (situações cotidianas e precedentes no repertório)

2. Experimentar as várias possibilidades de produção sonora com mãos

\footnotetext{
${ }^{30}$ O Portal apresentou na sua primeira versão na grande área "Orientações” as abas "Reflexões pedagógicas" e “Dicas para elaboração de aulas”, como já descritas na p.36.
} 
3. Criar uma peça musical com a sonoridade das mãos (Aula $\mathrm{N}^{\circ} 3$, autor: AT3, Caderno de aulas, p. 9 - 11). ${ }^{31}$

Na Aula $N^{\circ} 7$ :

Criar sons, desenvolver o ritmo e compor melodias a partir de instrumentos musicais criados com material reciclado (Aula $\mathrm{N}^{\circ} 7$, autor: AT 2, Caderno de aulas, p. $24-26){ }^{32}$

Na Aula N¹9 "Músicas - criação de canção: ritmo e gênero" do autor AT 7:

Relacionar os conceitos de ritmo e de gênero musical; Analisar estilo e forma de uma canção popular; Transformar o material musical original criando uma nova composição (Aula $\mathrm{N}^{\circ} 19$, autor AT 7 Caderno de aulas, p. $64-68) .^{33}$

Os objetivos, conforme Veiga (2008), atendem finalidades de natureza filosófica e política; gestão educativa; pedagógica e prática pedagógica. No âmbito particular desta pesquisa, interessam os referentes a finalidade pedagógica e prática pedagógica, uma vez que os demais se situam no âmbito da gestão escolar e do estado

A dimensão pedagógica refere-se as intenções e os objetivos gerais e específicos para a aula de Música, clarificando os propósitos e as intenções educativas, e orientando e guiando o processo didático. De forma mais especifica, a dimensão da prática pedagógica explicita o tipo de capacidade que se espera dos alunos. Essa última dimensão, deve ser expressada em verbos e associada, como já dito, à pergunta: “O que o aluno poderá aprender com esta aula".

A análise dos objetivos foi realizada em 20 aulas das 48 selecionadas na amostragem.

As ações expressadas em verbos foram organizadas com base às sugestões descritas na página "Orientações" do "Espaço da Aula" do Portal: verbos de ação conceitual, procedimental e atitudinal.

Como descrito por Imbernón (2008) o conteúdo conceitual na aula apresenta dois blocos diferentes: conceitos e sistemas conceituais; e fatos. Os fatos precisam atividades mais repetitivas e de memorização; os conceitos e sistemas conceituais precisam compreensão da ação, estruturadas no contexto e na ação. O conteúdo procedimental inclui habilidades, competências, estratégias. O conteúdo atitudinal inclui comportamentos, valores e normas.

\footnotetext{
${ }^{31}$ Anexo C

${ }^{32}$ Anexo D

${ }^{33}$ Anexo E
} 
Ao primeiro grupo de objetivos, conceituais, deu-se o numeral $1 \mathrm{com}$ as suas divisões 1.1 sucessivamente até o 1.7; ao segundo grupo, procedimental, o numeral 2 e numeração 2.1 sucessivamente até o 2.12; e ao terceiro grupo, atitudinal, o numeral 3 desde 3.1 até 3.5.

Os verbos organizados para análise são aqueles usados nos objetivos das 20 aulas selecionadas, como observado no gráfico 1 abaixo:

Gráfico 1 - Categoria objetivos, frequência de uso

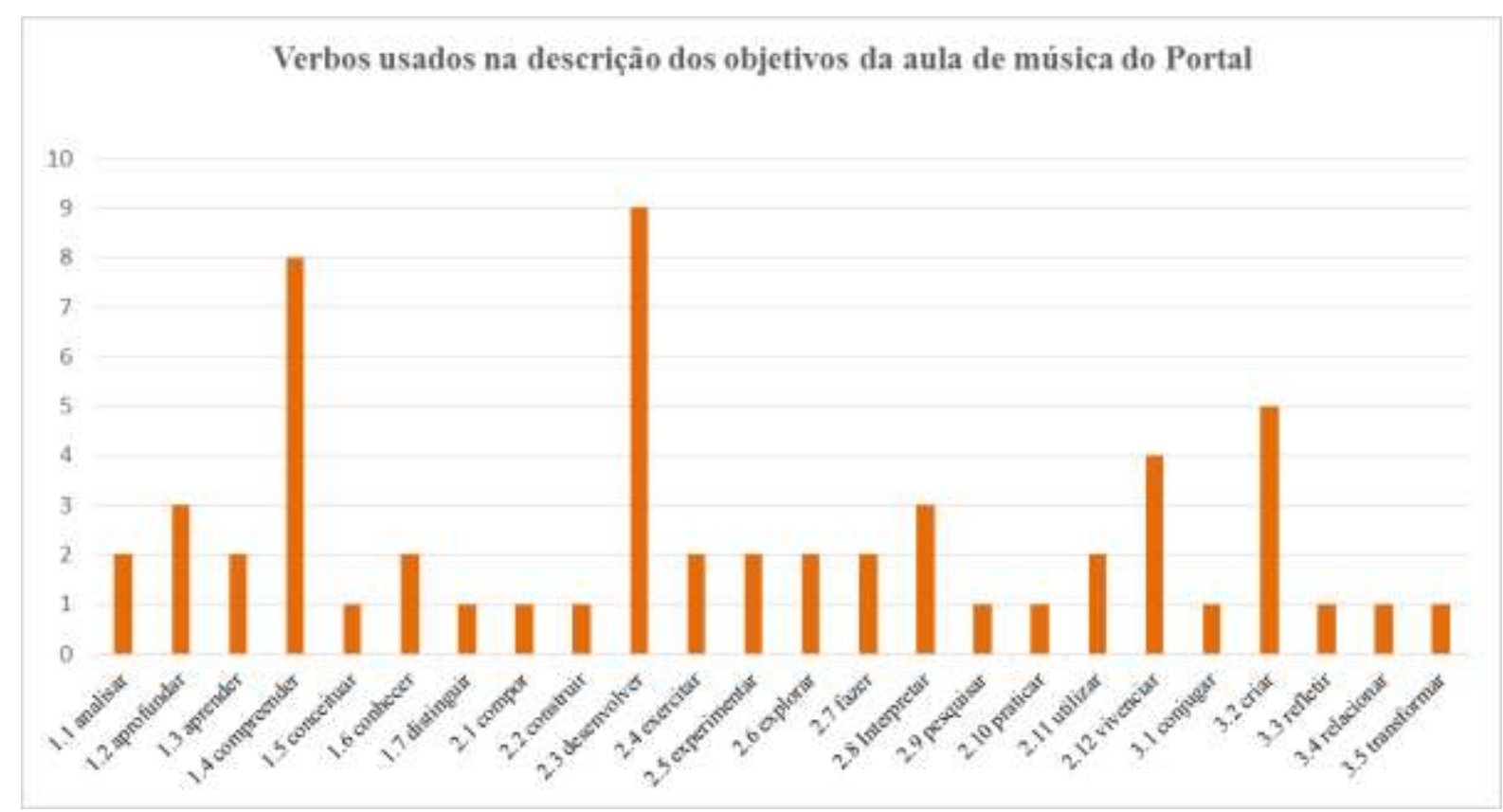

Fonte: Autora - dados da pesquisa. Organizado pela autora.

Os resultados mostram que nas 20 aulas analisadas há predominância dos objetivos de ação procedimental expressados em 12 verbos (compor, construir, desenvolver, exercitar, explorar, fazer, interpretar, pesquisar, praticar, utilizar, vivenciar), seguidos pelas ações conceituais com 7 verbos (analisar, aprofundar, aprender, compreender, conceituar, conhecer, distinguir) e com menor presença dos verbos atitudinais, 5 (conjugar, criar, refletir, relacionar, transformar).

É interessante observar a preferência dos autores pelo verbo "desenvolver", usado até duas vezes na descrição dos objetivos numa única aula, como acontece na aula $\mathrm{N}^{\circ} 15$, "MÚSICA- Oficina 3: paisagem sonora.":

O aluno deverá desenvolver habilidades na utilização de elementos sonoros na composição musical; $\mathrm{O}$ aluno deverá também exercitar sua capacidade criativa e expressiva, além de desenvolver-se na integração com o grupo e no trabalho em conjunto (Aula $\mathrm{N}^{\circ} 15$, autor: AT 3, Caderno de aulas, p. 53 - 54). 
Outras aulas com objetivos descritos com verbo "desenvolver": Aula N4, "MÚSICA - escrita e leitura musical: compasso (aula 2)":

Desenvolver noções sobre como ocorre a escrita musical para o parâmetro "duração". (Aula N 4 , autor: AT 3, Caderno de aulas, p. 15 - 16).

Aula N¹4, "Música - Trilha sonora - Projeto e Roteiro":

Desenvolver o projeto de trilha expondo as intenções pretendidas, linha de criação e os recursos necessários para a realização. (Aula $\mathrm{N}^{\circ} 14$, autor: AT 7 , Caderno de aulas, p. 49 - 52).

Aula N8, "MÚSICA - escrita e leitura musical: dominó com figuras musicais (aula 3):

Desenvolver noções sobre como ocorre a escrita musical para o parâmetro "duração". (Aula No8, autor: AT 3, Caderno de aulas, p. 27 - 30).

Outro dos verbos mais usados para expressar objetivos é "compreender" referindo-se a conceitos musicais como:

Aula N²0, "MÚSICA: Elementos de expressão (andamento) - accelerando e rallentando", objetivo:

Compreender as variações graduais de andamento em Música. (Aula $\mathrm{N}^{\circ} 20$, autor: AT 3, Caderno de aulas, p. 69 - 70).

Aula N4, "MÚSICA - escrita e leitura musical: compasso (aula 2):

Compreender como se estrutura e se grafa o ciclo de pulsações nas canções.(Aula N 4 , autor: AT 3, Caderno de aulas, p. 15 - 16).

O verbo "compreender" também é usado para contextos sociais como:

Aula $\mathrm{N}^{\circ} 13$, "O Funk carioca e sua dinâmica social”:

Também deverão compreender os valores políticos da cultura Funk e a sua inserção nas periferias das grandes cidades - suas reivindicações e percepção das mazelas da sociedade. (Aula $\mathrm{N}^{\circ} 13$, autor: AT 6, Caderno de aulas, p. 44 - 48).

Aula Nº18," Música - Gumboot Dancing, dança de resistência das minas da África do Sul - aula 01":

Compreender a atividade musical como forma de expressão de uma cultura: suas contradições, sua história e sua identidade. (Aula $\mathrm{N}^{\circ} 18$, autor: AT 1, Caderno de aulas, p. 60 - 63).

Quanto aos verbos que indicam ações atitudinais, pode-se observar no gráfico 1 acima que das 5 aulas que expressaram os objetivos com esses verbos, 4 foram mencionados uma única vez: relacionar e transformar na Aula $\mathrm{N}^{\circ} 19$, "Música - criação de canção: ritmo e 
gênero"; refletir na Aula N5, "A ponte"; e conjugar na Aula N²12, "Música - Jogos musicais com percussão corporal: percepção de ritmo - aula 4".

Ao relacionar com a proposta de modelo didático para educação musical de Jorquera (2010): tradicional nos modelos acadêmico e prático; comunicativo-lúdico e complexo, em que a autora descreve como finalidades:

1) no modelo acadêmico: finalidade de transmissão de conteúdo; formação instrumental especializada. No prático: o fim é o virtuosismo por meio de técnicas instrumentais;

2) no modelo comunicativo-lúdico (escola ativa): a música como linguagem, porém descontextualizada, com fins individuais de desenvolvimento pessoal e fins sociais para sociedade do espetáculo.

3) no modelo complexo: finalidade de compreender a realidade, promover a construção do conhecimento musical e do conhecimento humano contextualizado.

Pode-se inferir pelo gráfico 1 acima, que os objetivos das aulas de música analisadas descritos em verbos, correspondem, prncipalmente, ao modelo complexo, por envolver ações associadas a construção do conhecimento musical. Os 12 verbos de ação procedimental, mais frequentes - compor, construir, desenvolver, exercitar, explorar, fazer, interpretar, pesquisar, praticar, utilizar e vivenciar - expressam essa tendência. O verbo "desenvolver", o mais utilizado e presentes em 9 aulas, reforça a concepção de aulas visando a construção, desenvolvimento e assimilação do conhecimento musical.

Segundo Hentschke e Del Ben (2003) as finalidades da educação musical escolar devem ser a de auxiliar os alunos nos processos de "apropriação, transmissão e criação de práticas músico-culturais” (HENTSCHKE; DEL BEN, 2003, p.181). Nesse sentido, a aula de música deve propiciar o desenvolvimento e apropriação do conhecimento musical a partir da cultura do aluno e de outras culturas.

Nessa perspectiva, observa-se que os objetivos das aulas de música do Portal para atender às finalidades apontadas pelas autoras acima mencionadas, apresentam-se nos objetivos procedimentais dominantes e nas outras ações conceitual e atitudinal. É importante observar que os três objetivos mais utilizados "desenvolver" (9 aulas), "compreender" (8 aulas), criar (5 aulas) e vivenciar (4 aulas) correspondem respectivamente às ações procedimental, conceitual, atitudinal e procedimental. $\mathrm{O}$ que possibilita inferir que nas aulas 
de música do Portal, de maneira geral, há uma preocupação equilibrada com a formação prática, teórica e de valor dos estudantes.

A importância dos objetivos de natureza conceitual é expresso, por exemplo, pelo verbo "compreender" na aula $\mathrm{N}^{\circ} 1$, "Música - Canto coletivo na África do Sul (aula 02): "Tchotcholôsa" um canto de trabalho":

Compreender a atividade musical como forma de expressão de uma cultura: suas contradições, sua história e sua identidade. (Aula $\mathrm{N}^{\circ} 1$, autor: AT 1, Caderno de aulas, p. 1 - 6).

Na ação procedimental com o verbo "interpretar" na aula Nº6, "MÚSICA - Percussão corporal: Composição (aula 1)":

Interpretar uma melodia convencional com percussão corporal, observando diferenças de alturas (sons graves e agudos). (Aula $\mathrm{N}^{\circ}$ 6, autor: AT 3, Caderno de aulas, p. 20 - 23).

Quanto a ação atitudinal pode ser observado no verbo "criar" na aula $\mathrm{N}^{\circ} 17$, "MÚSICA - Percussão corporal: Composição (aula 2)":

Criar um acompanhamento rítmico com percussão corporal para uma melodia convencional associado a um estilo musical. (Aula $\mathrm{N}^{\circ} 17$, autor: AT 3, Caderno de aulas, p. 57 - 59).

Ou na Aula N5, “A ponte":

Refletir sobre a função e importância da capital do país ser instalada no planalto central brasileiro. (Aula $\mathrm{N}^{\circ} 5$, autor: AT 2, Caderno de aulas, p. 17 19).

A interpretação dos objetivos analisados nas 20 aulas demonstra que os autores estão atentos às sugestões do Portal para expressar com verbos de ação intenções que possam responder à pergunta inicial "O que o aluno poderá aprender com esta aula". Percebe-se também a preocupação, como observado no gráfico 1, de objetivos direcionados a processos de aprendizagem, mais do que na transmissão de conceitos ou práticas tecnicistas. Esse fato pode também ser um reflexo da avaliação das aulas quando da submissão ao Portal, o que demonstra também o caráter formativo da própria criação e publicação de aulas.

Contudo, questiona-se: até que ponto os objetivos expressos em verbos nas aulas de música, como solicitado pelo Portal, refletem exatamente o que se pretende que o aluno aprenda? Qual a coerência entre os objetivos, estratégias e desenvolvimento da aula e avalição?

Os verbos mais usados “desenvolver”(9 aulas), “compreender” (8 aulas), "criar” (5 aulas), "vivenciar" (4 aulas), poderiam estar descrevendo efetivamente as competências 
visadas pelo autor? Até que ponto os objetivos privilegiam competências segundo o conceito do INEP: “ações e operações que utilizamos para estabelecer relações com e entre objetos, situações, fenômenos e pessoas que desejamos conhecer”. (INEP, 2000, p. 5)? Nesse sentido, até que ponto verbos como "desenvolver", "vivenciar" e "aprofundar" são adequados ao planejamento de uma aula de música, uma vez que sugerem ações pouco objetivas e que respondem de forma vaga a pergunta "O que o aluno poderá aprender com esta aula?" ?

A análise dos objetivos das aulas de música aponta a importância da clareza na redação dos fins e metas das aulas de música. Contudo, observa-se que a clareza dos objetivos está relacionada diretamente com as próprias concepções de ensino e aprendizagem musical dos autores das aulas e com a forma como eles elaboram as estratégias das suas aulas. Nesse sentido, observa-se que a seleção de verbos pode ser uma escolha para atender as exigências do Portal e não, necessariamente, a aprendizagem do aluno.

\subsection{ESTRATÉGIAS}

O Portal do Professor concebe as estratégias e recursos como o roteiro do trabalho a ser realizado na aula. Como sugestão, ele propõe em "Dicas para elaboração de aulas" que as estratégias e recursos descrevam orientações para o trabalho dos alunos que sejam organizados e associados aos objetivos expressos na aula.

A elaboração de estratégias como sugeridas pelo Portal converge com a definição de Imbernón (2008) que a entende como referência para construir conteúdos, sendo baseada nos tipos de objetivos e conteúdo conceitual; procedimental e atitudinal.

Um dos desafios que o Portal considera mais importantes é o desenvolvimento das estratégias e da avaliação, sugerindo a prática do trabalho com projetos, como observado a seguir:

[...] algumas estratégias devem ser consideradas no processo educativo, tais como: trabalhos com projetos (métodos de projetos de aprendizagem ativa; de aprendizagem significativa), projetos colaborativos (aprendizagem em rede), projetos-web (webquest), mapas conceituais etc. (Portal do Professor, $2008)^{34}$

Nas aulas de música do Portal os trabalhos com projetos acontecem em alguns casos durante uma única aula ou em aulas sequenciadas. Contudo, apresentam-se uma tímida

\footnotetext{
34 A citação acima encontra-se no elemento Reflexões Pedagógicas da página "Orientações” da grande área "Espaço da Aula" do Portal do Professor (p.1)
} 
evidência das aulas com trabalhos colaborativos, das 20 aulas analisadas, 17 usam a internet, por exemplo.

Segundo Swanwick (1991) as estratégias de aulas de música podem ser desenvolvidas segundo modelos determinados na história da educação musical e ainda vigentes atualmente. O autor aponta quatro metáforas de professor de música com estratégias específicas e diferenciadas: professor Caixa Postal; professor Jardineiro; professor Agente Cultural e professor como Músico. O primeiro deles, Caixa Postal, planeja estratégias centradas na transmissão de conteúdo e nas habilidades instrumentais e de letramento musical; o Jardineiro, segunda metáfora, visa estratégias que privilegiam o desenvolvimento natural, com ênfase no trabalho em grupo, na improvisação e na "auto expressão"; o terceiro, Agente Cultural, adota estratégias sob uma visão sociológica, integrando etnias, ambientes culturais e tecnologias; e quarto, o professor como Músico é guiado por estratégias baseadas em princípios do fazer musical em que se visa o sentimento de realização e experiência musical direta. O princípio de realização diz respeito a atitudes de reconhecimento como: curiosidade, desejo de competência, imitação e necessidade de interação social. A experiência musical direta está relacionada ao fazer musical como compositor, como executante ou como ouvinte, visando a compreensão, a sensibilidade e o prazer musical.

No tipo de aula do professor como "Músico", Swanwick (1991) centra a sua atenção nas atividades fundamentais que permitem a experiência musical como apreciar; executar e compor; em que a técnica e literatura são atividades periféricas e complementares às três atividades fundamentais. No Brasil a sigla $(\mathrm{T}) \mathrm{EC}(\mathrm{L}) \mathrm{A}^{35}$ reflete o seu modelo de desenvolvimento musical. No (T)EC(L)A as atividades envolvem o conhecimento "sobre" música - técnica e literatura - e o conhecimento "como" (saber fazer) - apreciar, executar e compor.

Nas aulas de música do Portal observam-se as quatro metáforas ou modelos de ensinoaprendizagem musical descritas por Swanwick (1991). Algumas das aulas de música analisadas apresentam mais de um desses "tipos" nas estratégias utilizadas, ou seja, o início da aula pode ser um momento expositivo, transmitindo conceitos; na sequência os alunos imitam e repetem padrões musicais; noutro momento os alunos produzem "novas" criações, associadas a temas interdisciplinares ou a contextos sociais específicos, por meio de diálogos, debates e da incorporação de padrões rítmicos ou melódicos ou de um estilo musical.

\footnotetext{
${ }^{35}$ Na língua inglesa a sigla utilizada é CLASP - composicion, literature, appraising, skills, performance.
} 
Observa-se a dificuldade de tipificar as aulas. Percebe-se a importância do planejamento Complexo (JORQUERA, 2010) em que diferentes estratégias podem ser utilizadas. A diversidade é desejável para atender a diferenças de apreensão e aprendizagem.

Associada ao tipo Caixa Postal pode-se encontrar a Aula N4, "MÚSICA - escrita e leitura musical: compasso (aula 2)”. Nesta há uma preocupação pelas habilidades de letramento musical, o autor descreve notas explicativas como:

Nesta coleção de aulas vamos trabalhar com o parâmetro "duração" e como ele se estrutura na grafia musical tradicional do Ocidente, objetivando capacitar o aluno a entender o princípio gerador da sistematização das durações sonoras na escrita musical. (AT 3, MÚSICA - escrita e leitura musical: compasso [aula 2], Caderno de aulas, p. 15 - 16).

Um exemplo da metáfora do Jardineiro é encontrado na Aula N7, "Uma orquestra diferente". As estratégias que a autora usa como diálogo, experiência, pesquisa, interatividade com site/internet e apresentação à comunidade, evidenciam trabalho em grupo e a atenção ao desenvolvimento natural do aluno. Um trecho de sua aula é apresentado a seguir:

Após o áudio é hora dos alunos produzirem seus instrumentos.

Atenção professor! Auxilie os alunos na construção dos instrumentos musicais, escolha dos materiais, etc. Oriente a turma para compor uma música a partir dos instrumentos. Em Recursos Complementares indicamos um site com exemplos de instrumentos criados a partir de sucatas. (AT 2, "Uma orquestra diferente", Caderno de aulas, p. 24 - 26)

A metáfora do Agente Cultural é encontrado na Aula N¹, "Música - Canto coletivo na África do Sul (aula 02): "Tchotcholôsa", um canto de trabalho". Nela, para o desenvolvimento da aula, o autor apresenta o contexto cultural, relaciona a forma musical original à forma musical de tradição ocidental europeia e explica ao professor como explorar a aula a partir de termos sociológicos. Nas anotações para a aula o autor expressa o seguinte:

Professor(a) inicie a aula apresentando aos seus alunos a música "Tchotcholôsa". Você pode fazê-lo a partir dos vídeos disponíveis em "Recursos Complementares" abaixo, a partir de uma gravação, cantando uma mistura de suas vozes sem abrir mão da voz principal ou misturando estes diferentes recursos.

Fale um pouco para seus alunos a respeito do canto responsorial e de como este funciona em "Tchotcholôsa". Destaque o fato desta canção ter ganhado repercussão internacional por ter se tornado o hino informal da seleção de futebol sul-africana, mas que esta música representa, dentro da história sulafricana, um canto de orgulho, dignidade e liberdade. Destaque os aspectos que você julgar significativos acerca desse tema. (AT 1, Música - Canto 
coletivo na África do Sul (aula 02): "Tchotcholôsa", um canto de trabalho, Caderno de aulas, p. 1 - 6).

A aula na metáfora do professor como Músico: Aula N¹2, "Música - Jogos musicais com percussão corporal: percepção de ritmo - aula 4", o autor apresenta estratégias de experiência musical, em que a curiosidade e o sentimento de realização são percebidos no estímulo a realização do fazer musical.

Caro(a) professor (a), esta coleção de aulas tem o objetivo de apresentar diversas atividades voltadas para o desenvolvimento da percepção rítmica, utilizando o corpo como recurso sonoro. Tais atividades foram pensadas para alunos do $4^{\circ}$ e $5^{\circ}$ anos do Ensino Fundamental, o que não impede que sejam realizadas com séries mais adiantadas.

Vale ressaltar que a música corporal consiste em uma ferramenta valiosa (porém não exclusiva) para o ensino-aprendizagem em Música, visto que dispensa recursos materiais (como a utilização de instrumentos musicais) e é acessível a qualquer pessoa, em qualquer situação. [...]

[...] Durante o processo de "ensaio" dos grupos, você deverá orientá-los quanto à escolha das músicas e quanto à execução, auxiliando-os na conjugação do canto com a percussão corporal. Tenha em mãos algum instrumento de percussão para marcar a pulsação. Após um tempo de prática, cada grupo deverá apresentar suas escolhas para a turma. (AT 5, "Música Jogos musicais com percussão corporal: percepção de ritmo - aula 4", Caderno de aulas, p. 40 - 43).

Observa-se nas 20 aulas analisadas, uma variedade de atividades propostas atendendo aos objetivos elencados, ou seja, de ação conceitual, procedimental e atitudinal. Todas as aulas apresentam propostas a serem desenvolvidas em sequências que alguns autores denominam: momento, atividade ou etapa. As Aulas também podem integrar um projeto, nesse caso elas são numeradas e podem fazer parte de uma coleção ou seguir uma sequência de duas, três ou mais aulas. Esse procedimento é descrito no título da aula como ocorre, por exemplo, nas seguintes aulas: 1) Aula N¹ "Música - Canto coletivo na África do Sul (aula 02): "Tchotcholôsa", um canto de trabalho"; 2) Aula N4, "MÚSICA - escrita e leitura musical: compasso (aula 2)"; 3) Aula N 6, "MÚSICA - Percussão corporal: Composição (aula 1)" e 4) Aula N8 "MÚSICA - escrita e leitura musical: dominó com figuras musicais (aula 3)".

Nas estratégias do Portal se desenvolvem atividades com os diferentes conteúdos conceitual, procedimental e atitudinal; se descrevem o papel do aluno e, especialmente, o papel do professor e adicionam-se notas explicativas sobre conceitos propriamente musicais além de conceitos de contexto social e cultural. As estratégias apesar de diversificadas são 
diretivas e apresentam poucas sugestões de variância. Para pesquisas futuras é relevante investigar os usuários do Portal para identificar como aplicam as estratégias, o que observam e que modificações propõem.

\subsection{AVALIAÇÃO}

O Portal do professor considera a avaliação como um momentos formativo de atenção ao processo de ensino e aprendizagem, em que se observa e construção de conhecimento conceitual, procedimental e atitudinal do aluno. Na descrição do campo de avaliação da aula a ser criada e publicada, o Portal apresenta sugestões para o autor da aula. Dentre as sugestões se recomenda observar os instrumentos e estratégias que mostram "o quê" e "como" se efetivará a aprendizagem dos alunos. Como observado a seguir:

A avaliação deve ser consistente com o que propõem os objetivos de aprendizagem e deve incorporar as habilidades e competências dos objetivos. Não se trata aqui de provas e outras medições, mas de procedimentos que o professor pode se valer de forma que os alunos tenham oportunidade de comprovar a sua aprendizagem. (Portal do professor "Espaço da Aula", Criar Aula, passo 5).

Nas aulas analisadas, a avaliação é diversificada. Encontram-se aulas voltadas para a avaliação de aprendizagens atitudinais como na Aula N¹1, "MÚSICA - Percussão corporal: Boca", como observado a seguir:

Considere na avaliação:

1. a participação dos alunos na realização da melodia de diferentes formas

2. a qualidade, a variedade e a realização sonora da pesquisa de sons feita pelos alunos

3. a participação no exercício de acompanhamento de melodia (AT 3, "MÚSICA - Percussão corporal: Boca", Caderno de aulas, p. 38 - 39).

Imbernón (2008) recomenda como já dito, estabelecer no planejamento os momentos e as técnicas de avaliação a se usar, esses momentos podem ser definidos como: avaliação inicial; avaliação formativa e avaliação somativa. A avaliação inicial diz respeito ao diagnóstico; a avaliação formativa referente à observação contínua e a detecção de dificuldades encontradas, observa o processo; a avaliação somativa corresponde à 
comprovação de tarefas de revisão, são pontuais e objetivas e podem estar associadas também ao processo.

Nas 20 aulas analisadas encontramos algumas aulas que atendem aos três momentos indicados por Imbernón, como observado na Aula N7 "Uma orquestra diferente". Nesta, o autor descreve no campo indicado para avaliação a seguinte recomendação:

É importante que os alunos saibam desde o início da atividade os critérios de avaliação utilizados pelo professor, dessa forma saberão quais habilidades terão que desenvolver com a atividade. Nesse caso sugerimos que o professor avalie a participação do aluno nas discussões, o interesse dele pela temática, a compreensão do conceito, a interação com a turma e o materiais, e se o aluno atingiu o objetivo da proposta. Após a conclusão das atividades os alunos também deverão fazer um relatório individual informando as dificuldades encontradas durante a atividade e quais as formas de superação encontradas, sua contribuição para atividade, seu crescimento com relação ao conteúdo, etc. (AT 2, "Uma orquestra diferente", Caderno de aulas, p. 24 - 26).

Outro exemplo de avaliação que engloba os três momentos apontados por Imbérnon (2008) é observado na Aula $N^{\circ} 10$, “Tropicália: música, comportamento e atitude no Brasil da década de 1960”. A a seguir a descrição da avaliação realizada pelo autor:

A avaliação será realizada em todas as etapas do aprendizado:

- A pesquisa sobre as capas dos discos poderá ser apresentada pelos alunos utilizando equipamento de data-show. A pesquisa sobre os personagens mais importantes do Tropicalismo possibilitará ao aluno entrar em contato direto com a história da música popular brasileira e com a cultura geral do contexto. Essas atividades, assim como a redação do texto extraclasse, serão avaliadas seguindo exigências de clareza e pertinência histórica

- Durante o trabalho em grupo, os alunos serão avaliados segundo a sua capacidade de realizar tarefas coletivas como a interação e o diálogo, o respeito aos diferentes pontos de vista e o consenso entre opiniões divergentes;

- A escolha dos temas estudados em diálogo com as canções selecionadas deverá ser avaliada, levando-se em consideração a autonomia dos alunos em se tratando da capacidade de tomar suas próprias decisões a partir da análise pertinente do contexto histórico;

- Durante a produção dos Programas de Rádio, será avaliada a redação, a criatividade e a desenvoltura na utilização das ferramentas de edição de áudio, além da capacidade de trabalhar em grupo;

- O seminário interdisciplinar será um meio de avaliar a capacidade dos alunos de organizar e transmitir, de forma concatenada, o aprendizado adquirido durante as atividades. 
(AT 4, "Tropicália: música, comportamento e atitude no Brasil da década de 1960", Caderno de aulas, p. 34 - 37).

Encontram-se outras aulas que atendem unicamente aos resultados finais da avaliação, aspecto predominantemente somativo, como observado nas aulas a seguir:

Aula N¹9 "Música - criação de canção: ritmo e gênero":

Ao final da atividade, observe se os alunos atingiram os objetivos propostos. Avalie:

1. Relacionaram o conceito de ritmo ao de gênero musical?

2. Aprenderam a cantar a música "Cirandeiro", analisando seu estilo e forma?

3. Conseguiram transformar o material musical original criando uma nova composição?

4. Elaboraram canções com intenção de manter a forma e as palavras-chave?

5. Conseguiram discutir em conjunto a composição e tomar decisões em grupo?

6. Motivaram-se com a possibilidade de modificar músicas que conhecem? (AT 7, "Música - criação de canção: ritmo e gênero", Caderno de aulas, p. $64-68)$.

Aula $\mathrm{N}^{\circ} 12$, "Música - Jogos musicais com percussão corporal: percepção de ritmo aula 4":

O (a) professor (a) deverá observar se os alunos:

1) executaram os pares de blocos rítmicos propostos na Atividade 1, para internalização do novos modelos;

2) executaram os blocos rítmicos pares separadamente e em sequência, na Atividade 1;

3) executaram os blocos rítmicos pares em coro, na Atividade 2;

4) executaram os blocos rítmicos pares e ímpares em coro, na Atividade 2;

5) associaram os blocos rítmicos aos compassos das músicas cantadas, conjugando canto e percussão corporal; na Atividade 3;

6) identificaram as "músicas de encaixe" e as "músicas de não encaixe", evidenciando compreensão de compasso, na Atividade 3

(AT 5, "Música - Jogos musicais com percussão corporal: percepção de ritmo - aula 4", Caderno de aulas, p. 40 - 43). 
Segundo Swanwick (1991), a avaliação deve ser indicada por critérios qualitativos relacionados aos níveis de desenvolvimento apresentados na "Espiral de Desenvolvimento Musical" (EDM), observando tanto a dimensão pessoal quanto a dimensão social situada no lado direito da espiral ${ }^{36}$. O autor associa ainda os modos manipulativo, vernacular e idiomático aos descritores da avaliação. Estes são referentes às Dimensões Materiais, Expressão, Forma e Valor, descritas nas palavras do autor na página 71 desta Dissertação.

No Portal podemos observar aulas que refletem, pelo menos na descrição da avaliação, uma preocupação com as diferentes Dimensões e Modos da Espiral de Swanwick, como observado na Aula $\mathrm{N}^{\circ} 6$, "MÚSICA - escrita e leitura musical: dominó com figuras musicais (aula 3)":

Considere na avaliação:

1. a qualidade, a variedade e a realização sonora do inventário de sons listados pelos alunos e sua correção quanto às alturas

2. a participação na interpretação das melodias e nas atividades de criação

3. a estruturação musical e organização do grupo na realização do exercício de composição

(AT 3, "MÚSICA - escrita e leitura musical: dominó com figuras musicais (aula 3)").

$\mathrm{Na}$ aula $\mathrm{N}^{\circ}$ 6, o autor lista elementos musicais que se adequam a 3 modos da Espiral do Desenvolvimento Musical, situados no âmbito social da espiral (lado direito): 1) manipulativo, na identificação dos materiais sonoros; 2) vernacular, na interpretação de uma melodia que implica a apropriação expressiva, estereótipos e estruturas socialmente convencionados; 3) idiomático em que o uso dos recursos musicais indicam a assimilação de estruturas complexas dentro de estilos musicais.

Segundo Swanwick ( apud BARBOSA, 2009, s/n ), alguns critérios devem ser prérequisitos para a avaliação do fazer musical:

(a) devem ser claros;

(b) devem ser qualitativamente diferentes uns dos outros;

(c) devem ser breves o suficiente para serem compreendidos rapidamente, mas consistentes o bastante para serem significativos;

(d) devem ser passíveis de ser ordenados hierarquicamente em uma

\footnotetext{
${ }^{36}$ Swanwick (1991) em sua Espiral do Desenvolvimento Musical divide a espiral, horizontalmente, em dois âmbitos do conhecimento: pessoal e social. Nesse sentido, durante a aprendizagem há um movimento horizontal do âmbito pessoal, subjetivo para o âmbito social, intersubjetivo. Em cada um desses âmbitos o autor define 4 modos de aprendizagem, 8 modos no total: no âmbito pessoal, sensório, expressão pessoal, especulativo e simbólico; no âmbito social, manipulativo, vernacular, idiomático e sistemático (ver figura 11 p. 71)
} 
sequência clara e justificável;

(e) devem ser úteis em diferentes situações, incluindo níveis e estilos musicais diferentes;

(f) devem refletir a natureza essencial da atividade - no nosso caso, refletir a natureza da música.

Com base em sua "Espiral do Desenvolvimento Musical", Swanwick (2008; apud BARBOSA, 2009, s/n) sugere a seguinte formulação de critérios com base nos 9 níveis ou modos de desenvolvimento:

Nível 1 - aprecia / explora sons;

Nível 2 - classifica / controla os sons;

Nível 3 - identifica / produz formas expressivas;

Nível 4 - identifica / produz formas expressivas, clima/atmosfera;

Nível 5 - percebe / produz formas expressivas transformadas ou relações surpreendentes contrastadas;

Nível 6 - estabelece relação estrutural com idiomas específicos ou estilos;

Nível 7 - percepção e produção musical mostram forte identificação e comprometimento pessoal;

Nível 8 - relata a música com sustentação, original e independência envolvida $^{37}$ (Tradução BARBOSA, 2009, s/n)

A avaliação é fundamental no processo de ensino e aprendizagem, ela orienta tanto a gestão dos conteúdos quanto a ação docente. Percebe-se nas aulas de música analisadas uma preocupação com a avaliação qualitativa e formativa como orienta o Portal, contudo observase que como avaliar e o que avaliar é uma competência que precisa ser melhor apreendida pelos professores de música. Percebe-se ainda uma resistência a definição de critérios e descritores de avaliação, o que pode estar relacionado a percepção do senso comum de que o conhecimento musical é um dom e um conhecimento associado a estética, a cultura e a subjetividade dos indivíduos.

\subsection{RECURSOS}

\footnotetext{
37 Layer 1 - people enjoy / explore sounds; Layer 2 - they classify / control sounds; Layer 3 - they identify / produce expressive shapes, mood/atmosphere; Layer 4 - they identify / produce expressive shapes within common musical convenctions; Layer 5 - they perceive / produce expressive shapes in transformed or contrasting or surprising relationships; Layer 6 - they locate structural relationships within specific idioms or stiles; Layer 7 - their musical perception / production shows strong personal identification and commitment; Layer 8 - They relate to music with sustained, original and involved independence (SWANWICK, 2008, p.16) .
} 
O Portal esclarece ao autor criador da aula que os recursos são ferramentas didáticas para apoio ao ensino, que incluem diversas estratégias como leitura, socialização, trabalho em grupo ou interações com uso das TICs. A inclusão de recursos multimídia é uma exigência a ser incluída, contudo, o Portal nas suas "Reflexões Pedagógicas" atenta para sugestões de uso, como observado a seguir:

Inclua em suas estratégias Recursos Multimídia e de interação. Mas lembrese que a aula não deve ser simplesmente sobre o uso desses recursos, e sim, propor o uso das TICs de forma integrada ao currículo e para enriquecer a dinâmica de trabalho dos alunos. (Reflexões Pedagógicas, p.4)

Os recursos usados nas 20 aulas de música são apresentados no seguinte gráfico $2 \mathrm{em}$ que são observadas a frequência e os tipos de recursos usados.

Para melhor compreensão dessa categoria, os recursos foram divididos em: Multimídia, nos itens 1.1 a 1.8 e Ferramentas didáticas, nos itens 2.1 a 2.8. As ferramentas didáticas estão relacionadas aos materiais que incluem quadro; folhas de papel; livros; material impresso diverso; aparelhos e acessórios de reprodução e gravação convencionais. Os recursos multimídia incluem aqueles que têm relação direta com NTICs, dentre eles: softwares; vídeos; imagens; Objetos Virtuais de Aprendizagem; aulas do Portal do Professor; mídia; Ambientes Virtuais como plataformas ou redes sociais.

Observa-se nas aulas de música do portal a inclusão de NTICs em todas as aulas, atendendo a exigência do Portal para que essas sejam incluídas. Vários desses recursos estão disponibilizados no mesmo Portal, especialmente dentro da grande área "Multimídia", estes podendo ser incluídos na criação das aulas.

Os recursos multimídia disponibilizados pelo Portal incluem:

Vídeos; animações/simulações; áudios; imagens; experimentos; mapas; softwares educacionais, e hipertextos. Dentre as estratégias com multimídia, são disponibilizados: blogs; links de portais ou sites; podcasts ou áudios; google docs, wiki ou outro editor; softwares educacionais; salas de chat e fóruns; jornais eletrônicos e murais digitais. (PORTAL DO PROFESSOR, Reflexões Pedagógicas do Portal, p.4).

Considerando que uma grande maioria dos recursos mencionados pode ser acessado pela internet, para organização do processo da análise, realizou-se uma classificação de recursos por categoria multimídia e ferramentas didáticas tradicionais, como no quadro 17 a seguir: 
Quadro 17 - Recursos - Classificação

\begin{tabular}{|c|c|c|c|}
\hline \multicolumn{2}{|c|}{ RECURSOS } \\
\hline Multimídia & Item & Ferramentas didáticas & Item \\
\hline Imagens & 1.2 & Folhas de papel & 2.1 \\
\hline Áudios & 1.2 & Livros & 2.2 \\
\hline Vídeos & 1.3 & Dispositivos de reprodução & 2.3 \\
\hline Programas (softwares) & 1.4 & Outros dispositivos (Datashow, móbiles) & 2.4 \\
\hline Internet (sites, blogs, portal, redes & 1.5 & Quadro & 2.5 \\
\hline sociais) & 1.6 & Materiais de reciclagem e outros & 2.6 \\
\hline AVA (plataformas) & 1.7 & Instrumentos musicais & 2.7 \\
\hline Outras Aulas do Portal & 1.8 & Acessórios de gravação (microfone, câmara, & 2.8 \\
\hline Mídia (TV. Rádio, Filmes) & gravador, usb, sampler) & 2.8 \\
\hline
\end{tabular}

Fonte: Autora - dados da pesquisa. Organizado pela autora.

Com base na classificação elencada acima, realizou-se análise em 20 aulas de música, os resultados como observado no gráfico 2 abaixo, mostram o uso dos recursos multimídia por todas as aulas, atendendo as exigências do Portal.

Gráfico 2 - Categoria Recursos, frequência de uso

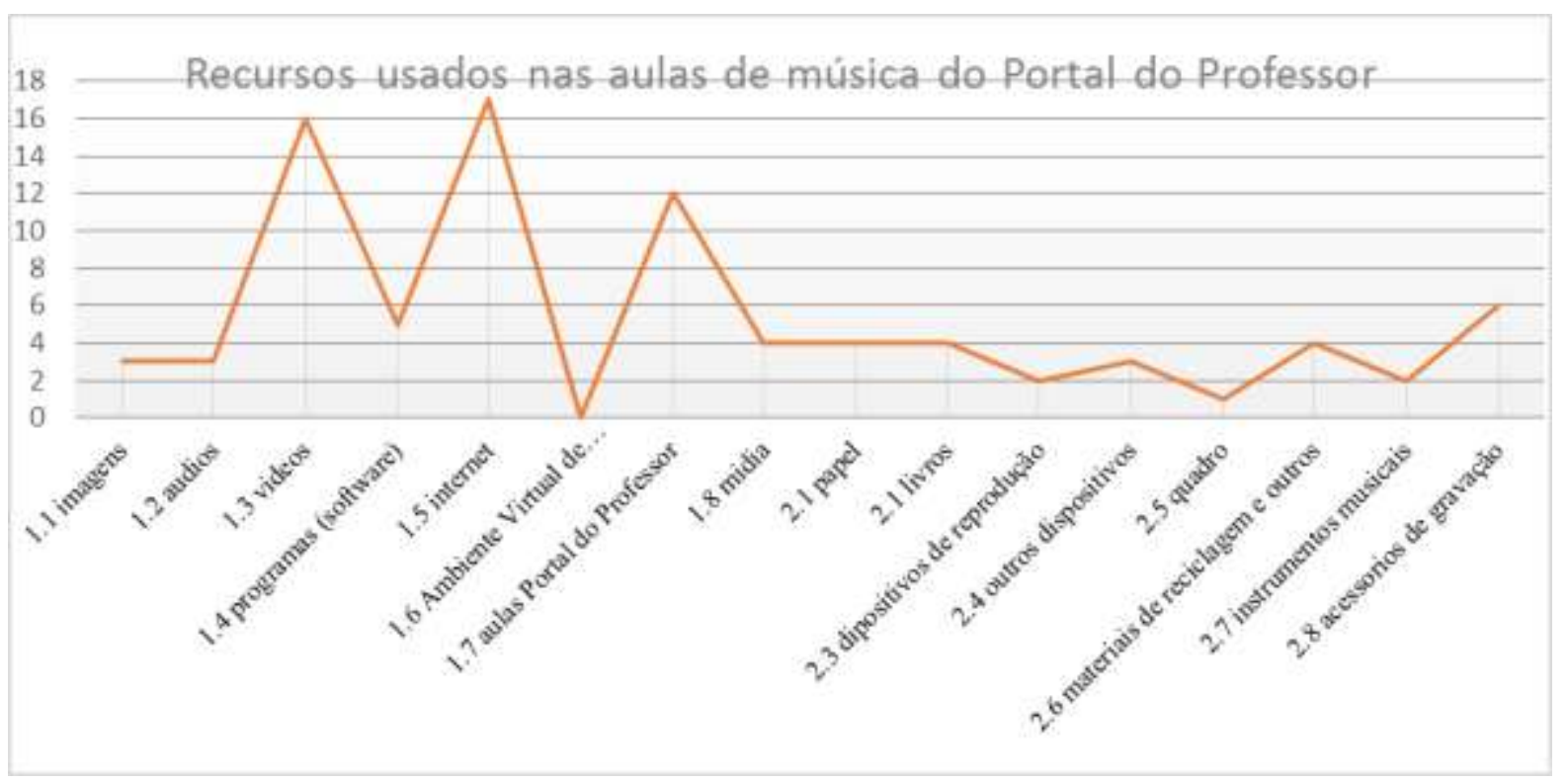

Fonte: Autora - dados da pesquisa. Organizado pela autora.

Observa-se a variedade de recursos nas duas categorias, porém com uma grande ênfase no uso dos recursos multimídia: 17 aulas de música das 20 aulas analisadas usam recursos da internet (item 1.5) como sites, blogs, wikis, redes ou aulas do mesmo Portal.

Encontram-se exemplos de uso de wikis, entre outras, por exemplo, nas Aulas $\mathrm{N}^{\circ} 1$, "Música - Canto coletivo na África do Sul (aula 02): "Tchotcholôsa", um canto de trabalho"; 
$\mathrm{N}^{\circ} 4$, "MÚSICA - escrita e leitura musical: compasso (aula 2)"; N7, "Uma orquestra diferente"; N8, "MÚSICA - escrita e leitura musical: dominó com figuras musicais (aula 3)".

Nos resultados tem-se, como observado no gráfico 2 acima, que 16 aulas de música das 20 analisadas, usam vídeos (item 1.3) obtidos de diversos sites da internet. Exemplos dessas aulas são: Aula N9, “MÚSICA: Construção de instrumento musical - violão de caixa de sapato"; Aula N¹1, "MÚSICA - Percussão corporal: Boca”; Aula №13, "O Funk carioca e sua dinâmica social"; Aula N¹8, "Música - Gumboot Dancing, dança de resistência das minas da África do Sul - aula 01”.

Nota-se também, pelo gráfico 2, que ainda as aulas não usam Ambientes Virtuais de Aprendizagem ou Plataforma virtual, talvez por não se disponibilizar no Portal esse recurso.

É interessante observar que só duas das 20 aulas usam instrumentos musicais (item 2.7), explicitados como tal, contudo há nas aulas prática instrumental de percussão corporal; canto; e outros materiais improvisados fazendo as vezes de instrumento musical, como observado a seguir: Aula $\mathrm{N}^{\circ} 14$, "Música - Trilha sonora - Projeto e Roteiro", na terceira atividade o autor descreve:

Baseado no roteiro construído, os alunos deverão agora empreender uma pesquisa sonora com objetos e outros recursos possíveis para a realização da trilha.

Para isso, disponha do equipamento de vídeo para que possam assistir novamente ao filme e experimentar os sons. Sugerimos que reúnam sucatas, objetos variados a serem usados como fonte sonora, instrumentos musicais, de preferência com antecedência, para que haja mais possibilidades de experimentação. (AT 7, "Música - Trilha sonora - Projeto e Roteiro", Caderno de aulas, p. 49 - 52).

Observa-se que cinco aulas de música das 20 aulas analisadas, usam programas ou software, o que indica a baixa interação dos estudantes com as NTICs. Como exemplo, a Aula N², "Música para quê?”, nessa aula a autora planeja uma atividade interativa, descrita a seguir:

Para instigar os alunos sobre os sons e verificar suas habilidades na identificação dos instrumentos musicais, sugerimos o recurso "ZORELHA" disponível no Portal do Professor. (AT 2, "Música para quê?", Caderno de aulas, p. 7 - 8).

Pode ser observada nas aulas analisadas, a atenção dos autores às sugestões e exigências do Portal, nota-se o entusiasmo no uso de recursos multimídia especialmente de informações levantadas pela internet. Contudo, apesar da recomendação do Portal, os recursos 
são, na maioria das vezes, utilizado como ilustração ou atividade complementar. Essa inferência pode estar associada a necessidade de formação tecnológica para os professore, com foco na dimensão pedagógica do uso das NTICs.

\subsection{AS AULAS DE MÚSICA PRINCÍPIOS E CONCEPÇÕES}

Nas 20 aulas analisadas foram observados princípios e concepções pedagógicas musicais expressas nos conteúdos das aulas de música e no papel do professor como gestor do conteúdo e da classe. Eles também se evidenciam na relação entre objetivos, estratégias e atividades, recursos e avaliação.

Por exemplo, percebe-se a presença interdisciplinaridade e da contextualização como um princípio, em que a música está associada a outras áreas do conhecimento e a habilidades não musicais. Nessa perspectiva, nas aulas do Portal observam-se atividades ligadas à prática musical e às questões do corpo, nas quais se incluem percussão corporal e dança. Aquelas que apresentam temas ligados a dança e contexto social são observadas em aulas como: Aula $\mathrm{N}^{\circ} 1$, "Música - Canto coletivo na África do Sul (aula 02): "Tchotcholôsa”, um canto de trabalho"; Aula N¹8 "Música - Gumboot Dancing, dança de resistência das minas da África do Sul aula 01", as duas aulas referem-se a cantos acompanhados por dança da África do Sul, como observado as seguir:

O Gumboot Dancing é um tipo de dança que inclui a percussão corporal. Professor(a), tome o cuidado, ao utilizar a percussão corporal, de explicar aos seus alunos que eles não devem se machucar. Para obter um som bonito e alto não é necessário utilizar a força, e sim um toque preciso. No caso de palmas nas coxas, a mão ligeiramente em concha ajuda a obter um maior volume. Para as batidas com os pés no chão, não é necessário utilizar força, o que pode gerar dores no pé, apenas bater com a sola da galocha ou do calçado de forma adequada. Essa forma tem que ser estudada e testada até que se consiga dominá-la tranquilamente para a performance. (AT 1, "Música - Gumboot Dancing, dança de resistência das minas da África do Sul - aula 01", Caderno de aulas, p. 60 - 63).

O princípio da contextualização encontra-se, principalmente, ligado a temas de cultura, etnia e contexto social. Foram encontradas 8 aulas em que esse princípio predomina: Aula N¹, "Música - Canto coletivo na África do Sul (aula 02): "Tchotcholôsa”, um canto de trabalho"; Aula N², "Música para quê?"; Aula N5, "A ponte"; Aula N¹0, "Tropicália: música, comportamento e atitude no Brasil da década de 1960"; Aula N¹3, "O Funk carioca e sua dinâmica social”; Aula N¹4, "Música - Trilha sonora - Projeto e Roteiro"; Aula Nº16, 
"MÚSICA - Oficina 4 - O universo do DJ" e Aula N¹8, "Música - Gumboot Dancing, dança de resistência das minas da África do Sul - aula 01”. A seguir algumas citações com referência ao contexto social da Aula $\mathrm{N}^{\circ} 13$ :

Atividade 1:A principal motivação em se estudar o Funk em sala de aula é podermos situar sua inserção na cultura brasileira e entender como se conjugam o estilo musical e a juventude que faz parte de sua tribo. Para tal tarefa, teremos que traçar o histórico deste estilo musical e suas variações. Para tal atividade, faremos um Seminário em que os alunos terão que descrever as principais características deste estilo musical. Por se tratar de um tema de interesse da juventude, possivelmente a turma terá algum conhecimento sobre o tema.

Atividade 2:Sabe-se que o estilo musical Funk surgiu nas favelas do Rio de Janeiro. O Funk é portador da complexa função de trazer à cena pública ideias, reivindicações, histórias e desejos de uma extensa camada da juventude brasileira. Por vezes, o estilo musical foi reduzido e acusado de fazer apologia ao crime organizado. Será interessante nesta atividade discutir livremente com os alunos essa "função" do Funk. (AT 6, "O Funk carioca e sua dinâmica social", Caderno de aulas, p. 44 - 48)

A atividade de produção musical é muito frequente nas aulas. De modo geral, pede-se aos alunos para realizarem produtos musicais como resultado das experiências sonoro-musicais realizadas em sala de aula. Entre as aulas analisadas, foram encontradas oito aulas que exploravam a produção musical, contudo, nos procedimentos de aula indicados pelos autores o processo de como motivar o aluno ou de como desenvolver o produto são apresentados de forma tímida ou pouco evidenciados. A seguir alguns exemplos:

Observe se os grupos se envolveram de fato na atividade e compuseram peças completas com quantidades de pulsos correspondentes aos compassos. Os grupos deverão estar aptos a executar suas peças sem erros ou dificuldades, assim como deverão estar aptos a fazê-lo com os trabalhos dos colegas.

Discuta cada composição com todos os alunos e encoraje-os a opinar sobre os trabalhos. (Aula N ${ }^{\circ}$, AT 3, 'MÚSICA - escrita e leitura musical: dominó com figuras musicais (aula 3), Caderno de aulas, p. 27 - 30).

... Pode ser utilizado os registros escritos, as produções de música dos alunos para avaliar. (Aula N5, AT 2," A ponte”, Caderno de aulas, p. 17 - 19).

Há ainda aulas em que predominam a ideia da aula de música como aprendizagem de escrita e leitura musical - cinco aulas: Aula Nº4; Aula Nº6; Aula Nº; Aula N¹9; Aula ํ⒛ A seguir, exemplo da Aula $\mathrm{N}^{\circ} 4$ : 
-Desenvolver noções sobre como ocorre a escrita musical para o parâmetro "duração".

-Aprofundar o conceito e a vivência da pulsação na música.

-Compreender como se estrutura e se grafa o ciclo de pulsações nas canções.

-Conceituar compasso. (AT 3, "MÚSICA - escrita e leitura musical: compasso (aula 2)", Caderno de aulas, p. 15 -16).

O tema da interdisciplinaridade predomina nas aulas: Aula $\mathrm{N}^{\circ}$; Aula $\mathrm{N}^{\circ} 5$ e Aula $\mathrm{N}^{\circ} 10$ como observado na seguinte citação:

Os alunos irão aprender o que foi o movimento musical conhecido como "Tropicalismo" e qual foi a sua importância histórica no cenário artístico, cultural e social brasileiro da década de 1960.

COMPONENTE CURRICULAR E TEMA

Língua Portuguesa Análise linguística

História Cidadania e cultura contemporânea

História Cultura

Artes Música: desenvolvimento da linguagem musical

Artes Música: Contextualização

História

(AT 4, " Tropicália: música, comportamento e atitude no Brasil da década de 1960", Caderno de aulas, p. $34-37$ ).

É frequente o planejamento de aulas centradas no professor, este como quem organiza, guia, esclarece, aponta, exemplifica, modela, seleciona, expõe, o que sugere a metáfora do professor Caixa postal, aquele que detém o conhecimento a ser transmitido. Observa-se esse tipo de aula na seguinte citação da Aula $\mathrm{N}^{\circ} 9$ :

Inicie a aula cantando um pequeno fragmento musical. A seguir, cante a mesma coisa projetando a voz para dentro de uma caixa, vasilha ou lata. Pergunte o que aconteceu. Explique que as ondas sonoras entram na "caixa" e saem amplificadas. Os chamados instrumentos de cordas se utilizam desse princípio para fazer com que as vibrações das cordas sejam ouvidas.

Explique que a família dos instrumentos de corda é muito extensa e que possui diferentes integrantes por inúmeros lugares do planeta - todos usando o mesmo princípio. Diga que o instrumento a ser construído hoje também pertence a essa família.

Converse com os alunos sobre a importância da reciclagem e do reaproveitamento de materiais. Atente para a necessidade da diminuição da produção de lixo no nosso planeta. Mostre o material que será utilizado e diga que ao invés de jogá-lo no lixo - como ocorreria normalmente - nós o transformaremos num instrumento musical. (AT 3, "MÚSICA: Construção de instrumento musical - violão de caixa de sapato", Caderno de aulas, p. 31 $-33)$. 
Contudo, a variedade de atividades ou momentos da aula evidencia também atividades a serem realizadas ou executadas pelos alunos.

A representação da linguagem musical utilizada nas aulas de música do Portal adota, principalmente, a grafia "tradicional": figuras e notas musicais e outras imagens e gráficos comumente usados na partitura como pentagrama e clave.

Nas aulas de música do Portal pode-se observar o uso da grafia musical nos conteúdos de domínio da linguagem musical, como observado na Aula N²0, "MÚSICA: Elementos de expressão (andamento) - accelerando e rallentando". Nessa o autor apresenta imagens de partituras para canto e piano. Como nas orientações para o professor apresentadas abaixo:

Explique que em Música temos a mesma situação, momentos musicais que podem estar mais rápidos ou lentos. Muitas vezes desejamos acelerar ou retardar a velocidade (andamento) durante a peça musical. Explique que essas mudanças podem ser registradas e que existem termos específicos utilizados tradicionalmente para isso. Quando queremos aumentar a velocidade da pulsação utilizamos a palavra accelerando e quando queremos diminuí-la, utilizamos a palavra rallentando. Ambas são palavras italianas, a primeira significa acelerando, aumentando a velocidade; e a segunda significa retardando, diminuindo a velocidade. Também é possível encontrar a indicação com suas abreviaturas: rall. ou accel..

Veja como aparece registrado na partitura. Exemplo de trecho com rallentando: ... (AT 3, "MÚSICA: Elementos de expressão (andamento) accelerando e rallentando", Caderno de Aulas, p. 69 - 70).

O uso de analogias entre músicas, estilos musicais, períodos históricos e outras área do conhecimento são frequentes nos planejamentos de aula de música do Portal, e essa evidência é expressa na Aula $\mathrm{N}^{\circ} 1$, "Música - Canto coletivo na África do Sul (aula 02): "Tchotcholôsa", um canto de trabalho". O autor apresenta uma nota explicativa, para o professor que fará uso da aula, sobre o significado da canção africana a ser trabalhada e complementa fazendo uma analogia com a forma musical ocidental europeia conhecida como "canto responsorial". Essa informação indica como o professor autor pensa e compreende o conhecimento musical para ensinar. Nesse caso, ele aproxima duas práticas musicais distintas culturalmente e temporariamente e propõe que o professor em sala de aula desenvolva o conceito de canto responsorial.

A seguir um dos objetivos apresentados e uma seção da nota explicativa descrita pelo autor da aula: 
Compreender a importância do canto coletivo na cultura sul-africana, a especificidade do canto responsorial e os paralelos dessas manifestações na cultura brasileira e em outras culturas.

... Não fica muito clara a distinção entre a denominação responsorial ou antifonal para este tipo de manifestação musical, provavelmente pelo fato de que as classificações da nossa teoria musical baseiem-se mais nos modelos advindos da cultura centro-europeia. (AT 1, "Música - Canto coletivo na África do Sul (aula 02): "Tchotcholôsa", um canto de trabalho", Caderno de aulas, p. $1-6)$.

Pode-se inferir que as aulas de música do Portal são representações de aula de música escolar expressas nas notas explicativas que acompanham os planejamentos ou no uso dos recursos digitais. Elas refletem princípios e concepções pedagógicas musicais expressas no trabalho colaborativo entre autores e coautores. 


\section{CONSIDERAÇÕES FINAIS}

A realização desta pesquisa teve como objetivo analisar e descrever as aulas de música disponibilizadas no "Espaço da Aula" do Portal do Professor do MEC; identificando autoria e coautoria; como são planejadas: quais conteúdos, objetivos, atividades, recursos e avaliação são utilizados.

Para alcançar esses objetivos foi feita uma pesquisa de análise documental, em que os fatos encontram-se nos documentos textuais que, nesta pesquisa, referem-se às aulas de música disponibilizadas no "Espaço da Aula" do Portal do Professor. No processo, incluiu-se uma combinação dos dados qualitativos e quantitativos que se complementam na análise e interpretação.

Os dados quantitativos basearam-se na análise de 48 aulas de música resultantes da amostragem com sorteio aleatório considerando os elementos de apresentação da aula no Portal, ali chamados de "campos fixos". A análise para esses campos focou na identificação de autores; coautores, instituição de vinculação dos autores; lugar ou região de criação e publicação das aulas. A interdisciplinaridade pôde ser observada tanto nos "campos fixos" do Componente Curricular e do Tema quanto nos "Campos abertos" destinados aos Objetivos e Estratégias e foi abordada na interpretação das 20 aulas.

Os dados qualitativos envolveram a análise de 20 das 48 aulas da amostragem, focando na análise dos chamados "Campos abertos" do Portal, relativos aos componentes do planejamento Objetivos, Estratégias, Recursos e Avaliação e com base na análise desses buscou-se interpretar as aulas a fim de observar seus elementos e orientações pedagógicomusicais.

Procurou-se, primeiramente, fundamentar o contexto em que está inserido o Portal do Professor do MEC como REA. E, aos poucos, houve uma revisão da literatura oficial para fundamentar o seu funcionamento e seu processo de ensino e aprendizagem; bem como estabelecer parâmetros de análise das aulas de música disponibilizadas no Portal.

Nesse contexto, os resultados apresentados das 48 aulas analisadas respondem às questões da pesquisa que foram investigadas:

Como são as aulas de música disponibilizadas no Portal do Professor? Que recursos utilizam? Como são planejadas (objetivos, atividades, recursos, avaliação)?

Os resultados da análise realizada mostram o desejo, o entusiasmo e a necessidade da incorporação de NTICs na aula de música, evidência expressada nos planejamentos 
disponibilizados no Portal. Importante destacar que o uso de recursos multimídias é também uma exigência para a criação e publicação de aulas no Portal. A pesquisa revela, contudo, que em muitas aulas os recursos multimídias e as NTICs são recursos secundários e usados como ilustração ou exemplos de teorias e atividades. Eles não são efetivamente meio ou instrumento de ensino e aprendizagem.

Com relação aos recursos utilizados nas aulas analisadas, observa-se uma grande ênfase no uso dos recursos multimídia com uso da internet como sites, blogs, wikis e aulas do mesmo Portal. O recurso mais usado na internet é o vídeo, este apresentando e exemplificando modelos de músicos e grupos musicais. As wikis na sua maioria são usadas para esclarecimento de conceitos musicais e os blogs para complementar temas de contexto social. Nos sites, encontram-se aqueles que disponibilizam vídeos, como "youtube" e "vimeo"; que disponibilizam letras de canções; e seções de gravações nacionais e internacionais de rádio e TV cultural.

Os recursos que foram classificados como ferramentas didáticas e se diferenciam daqueles que utilizam a internet apresentaram menor aplicação. Os autores são menos motivados, pelo Portal, a utilizar recursos tradicionais como quadro ou lousa; folhas de papel; livros e até mesmo instrumentos musicais. Infere-se que os autores ao não citar recursos pedagógicos tradicionais nas suas aulas, deixam em aberto a complementação das estratégias didáticas para o professor em sua sala de aula.

Quanto a pergunta: como são planejadas as aulas? Os resultados da análise apresentam os planejamentos das aulas de música atendendo às exigências do Portal relativo aos componentes: objetivos, atividades, recursos e avaliação. Estes determinados com "campos abertos" no processo de criação de aulas pelo professor. Destaca-se ainda que o planejamento das aulas é avaliado pela equipe do Portal durante o processo de submissão. Esse fato restringe o planejamento às concepções e princípios pedagógicos do Portal e, a análise realizada revelou que muitos planos de aula apresentam conflito entre as orientações e exigências do Portal e as próprias concepções dos autores e coautores. Essa hipótese pode ser temática para pesquisas futuras.

Os objetivos das aulas de música analisadas atendem às sugestões do Portal quanto a ação em forma de verbos associados a conteúdos conceituais, procedimentais e atitudinais. Os resultados da análise mostram ênfase nos objetivos de tipo procedimental, seguido pelas ações de tipo conceitual e com menor presença do tipo atitudinal. Há preferência dos autores pelo verbo "desenvolver" visando a aquisição de habilidades, competências e estratégias; e 
pelo verbo "compreender" nas ações de memorização e entendimento de conceitos musicais; informações sobre o contexto social e sobre os significados da atividade realizada pelo aluno. Percebe-se nas aulas uma ambiguidade de entendimento dos conceitos das ações cognitivas que envolvem "desenvolver" e "compreender". Observa-se a necessidade de melhor interação entre os componentes objetivos, estratégias e avaliação. Esta deve estabelecer critérios claros para verificação do desenvolvimento e da compreensão, o que não é claro nas aulas analisadas. A relação entre objetivos e avaliação é outro tema que merece aprofundamento em pesquisas futuras.

Quanto às atividades, no capítulo sobre a fundamentação da literatura ao respeito da aula e o planejamento da aula, essa operação inclui-se no componente método e atividades. As aulas de música do Portal apresentam atividades para definir momentos e sequências de aulas, algumas delas desenvolvidas como projetos sequenciais. As estratégias envolvem atividades cinestésicas; de audição como apreciação musical; prática musical em conjunto; debates; composição colaborativa, jogos interativos ou de interação com programas de edição. Elas apresentam estratégias em que predominam, em algumas aulas, ações centradas no professor e, em outras, ações centradas no aluno. As estratégias, de modo geral, são coerentes com os objetivos e procuram desenvolver, passo a passo, os conteúdos procedimentais, conceituais e atitudinais. Observa-se que, apesar das orientações do Portal quanto aos objetivos centrados no aluno, as estratégias apresentam concepções tradicionais de aula de música em que o professor é o centro do conhecimento como é caracterizado o professor caixa postal.

De acordo com os resultados da análise, os autores das aulas preferem para as primeiras atividades da aula, estratégias de ação por parte do professor. As aulas em geral apresentam notas descritivas para o professor que aplicará a aula. Estas abordam conceitos musicais e detalham estratégias recomendadas como: de que forma assistir um vídeo; como apresentar um conceito para os alunos; como desenvolver uma prática de apreciação musical; como fazer questões; como se comportar na aula; e ainda apresentam-se notas explicativas que preveem o comportamento dos alunos, para assim, alertar o professor. Esses cuidados denotam o caráter formativo das aulas do Portal. Portanto, nas estratégias das aulas de música, os autores descrevem, principalmente, o fazer do professor e lhe esclarecem conceitos e ideias musicais. Esse tipo de informação também sugere a complementação pedagógico-musical e musical de professores não especialistas, o que apresenta uma situação questionável: até que ponto as informações são suficientes para desenvolver competências e habilidades 
pedagógico-musicais e musicais para o professor não licenciado em música? As informações disponibilizadas pelos autores possibilita a auto-formação e a autonomia da docência em música? Essa temática também pode ser tema de pesquisas futuras: qual a formação do professor usuário das aulas de música do Portal?

Quanto à avaliação, os resultados apresentados na análise das 20 aulas mostram uma grande inclinação para estratégias de observação e de verificação da aprendizagem de conceitos e produtos musicais. As aulas utilizam instrumentos de avaliação para execução de produtos musicais e para a participação em debates, por exemplo. A avaliação de tipo atitudinal utiliza estratégias de observação para verificar comportamentos e interesses dos alunos. Destaca-se ainda a preocupação de algumas aulas com momentos diferenciados de avaliação que envolvem avaliação inicial, formativa e somativa.

Quanto a proposta da teoria de desenvolvimento musical de Swanwick, é interessante observar que embora essa não seja explicitamente mencionada, as aulas apresentam uma preocupação com 3 modos de desenvolvimento musical (manipulativo, vernacular e idiomático) nas dimensões Materiais, Caráter Expressivo e Forma. Considera-se ainda que a avaliação proposta na espiral de desenvolvimento musical permite a experiência musical direta nas quatro dimensões (Materiais, Caráter Expressivo, Forma e Valor) e seus 8 modos (sensorial e manipulativo; pessoal e vernacular; especulátivo e idiomático; simbólico e sistemático) segundo a história e vivencia pessoal dos aluno e o contexto sociocultural e histórico da música ocidental e de outras culturas. A análise mais aprofundada das aulas sob a perspectiva da Espiral do Desenvolvimento Musical também pode ser objeto de pesquisas futuras.

Considerando as conclusões apresentadas, as aulas de música no "Espaço da Aula" do Portal do Professor são um espaço singular de socialização de experiências de aula de música que apresenta recursos das NTICs como ferramentas de apoio de atividades. As aulas de música podem ser criadas e publicadas como temas interdisciplinares e em outros componentes curriculares além de Artes. Elas são material de livre aceso e uso, podendo ser adaptadas, copiadas, consultadas como modelo na sua íntegra ou em partes, ou podem, ainda, serem utilizadas como guia para elaboração de outras aulas.

Essas características evidenciam a aula de música do Portal como um Recurso Educacional Aberto-REA, contudo, durante a pesquisa identificou-se aulas que contém recursos multimídia removidos ou de acesso restrito devido a questões de licenciamento. Os assuntos sobre licenciamento do Portal são, atualmente, revisados nas políticas públicas. 
As NTICs usadas nas aulas de música do Portal são ferramentas de apoio nas atividades e mostram-se mais como estímulo visual e auditivo do que estratégias de ensino e aprendizagem. Verifica-se ainda que o tipo de ferramentas de maior uso nas aulas é de fácil acesso e manipulação. Essas ferramentas nas aulas se apresentam com várias funções: ampliar exemplos musicais; mostrar experiências musicais que tem sido registradas; complementar informações de contexto social; e servir de apoio na aprendizagem de conceitos musicais, letras, melodias e ritmos.

Não obstante a exploração de estratégias de colaboração e interação com NTICs, estas ficam limitadas quando utilizada unicamente como ferramentas de apoio nas atividades. Não se constata a participação dos alunos em blogs, fóruns, murais, jornais, jogos wikis ou redes sociais. Esse fato reduz a experiência da inovação com novas tecnologias retirando da sigla o termo comunicação. O elemento inovador nas aulas de música parece ficar no uso de materiais "atraentes", devida à quantidade de informação de que se possa dispor, à aparência vistosa, e a fácil disponibilidade.

A incorporação de estratégias com NTICs nas aulas de música do Portal motivam a transformação d papel do professor como detentor do conhecimento. Contudo, esse papel foi modificado na prática e aplicação das aulas? Os autores e usuários das aulas disponibilizadas no "Espaço da Aula" transformaram o seu fazer em sala de aula? Até que ponto as NTICs na sala de aula representam um recurso de motivação ou de apoio material de moda ou de consumo tecnológico? Até que ponto o Portal como REA pode provocar mudanças no fazer do professor? Até que ponto o o Portal assume ou dá espaço para essas mudanças?

As aulas de música quando publicadas e disponibilizadas no Portal representam um modelo alternativo à tradição, que interage na "cibercultura", na informação e nas comunicações em rede. Contudo, o Portal também é modelo de comunidade virtual, de prescrição e de referência. De igual modo, as aulas de música no Portal revelam as concepções e princípios de aula de música dos professores autores e de suas instituições. Os autores das aulas trazem da sua própria experiência como alunos, como professores e como sociedade em rede, as concepções e modelos de aula de música que eles já incorporaram. Portanto, as aulas refletem o pensamento e a ação do professor, revelam diferentes modelos e concepções de docência e de aula de música os quais são socializados na rede. Além disso, as aulas socializadas são abertas a novas ideias e a interação no espaço do Portal.

Esta pesquisa se caracterizou um estudo exploratório e descritivo que apresenta dados e evidências a serem aprofundados. Dentre os possíveis desdobramentos deste estudo 
destacam-se: 1) investigar a baixa participação de professores, instituições e Estados na produção de aulas de música; 2) investigar a baixa incidência da "revisão" e de propostas de "modificação" nas aulas publicadas; 3) investigar as experiências práticas de professores e usuários com as aulas disponibilizadas no Portal; 4) investigar as concepções ou representações sociais de aula de música mediadas pelas NTICs e publicadas no Portal; 5) investigar o impacto das aulas planejadas no Portal na aprendizagem dos alunos, a partir dos relatos dos professores e usuários.

Para além dessas sugestões de pesquisa, pode-se pensar em investigações que promovam a criação de novos recursos e estratégias que enriqueçam as experiências musicais das aulas de música propostas no Portal. Da mesma forma, espera-se contribuir com investigações sobre as aulas de músicas publicadas em recursos educacionais abertos produzidos em outros países, aproveitando-se da Rede de Portais da América Latina-RELPE da qual o Portal do Professor do MEC faz parte.

Espera-se que esta dissertação contribua com novos estudos e pesquisas na área de Educação Musical Escolar, na área de Formação de Professores de Música e na área de Recursos Educacionais Abertos. 


\section{REFERÊNCIAS BIBLIOGRÁFICAS}

ALVES, Rubem. Se é bom ou se é mau... In: As melhores crónicas de Rubem Alves. Campinas: Papirus, 2008.

AMIEL, Tel; OREY Michael; WEST, Richard. RECURSOS EDUCACIONAIS ABERTOS (REA): modelos para localização e adaptação. Revista Educação Temática Digital, Campinas, v.12, n.esp., p.112-125, mar. 2011 - ISSN: 1676-2592.Disponível em:

http://www.fae.unicamp.br/revista/index.php/etd/article/view/2284/pdf_69, acesso em Out. 16 de 2013.

ARAUJO, José Carlos Souza. Disposição da aula: os sujeitos entre a tecnia e a polis. In VEIGA, Ilma, Passos, Alencastro (Org.) Aula: Gênese, dimensões, princípios e práticas. Campinas: Papirus, 2008.

BABBIE, Earl. A lógica da amostragem do survey. In: Métodos de pesquisas de survey. Belo Horizonte: Editora UFMG, 2005.

BARBOSA, Karla Jaber. Conexões entre o desenvolvimento cognitivo e o musical: Estudo comparativo entre apreciação musical direcionada e não direcionada de crianças de sete a dez anos em escola regular. (2009) Dissertação (Mestrado). Música. Escola de Música da Universidade Federal de Minas Gerais. Belo Horizonte.

BAUER, Martin, W.; GASKELL, George. Pesquisa qualitative com texto, imagem e som: Um manual prático. Petrópolis: Vozes, 2003.

BIELSCHOWSK, Carlos Eduardo; PRATA, Carmem Lúcia. Portal Educacional do Professor do Brasil. Revista de Educación. Brasília, 352. Mayo-agosto 2010. Disponível em: http://portaldoprofessor.mec.gov.br/storage/materiais/0000013441.pdf acessado em 25 e 31/05/2013.

BLURTON, C. New Directions of ICT-Use in Education. Paris: UNESCO, 1999. Disponível em http://www.unesco.org/education/lwf/dl/edict.pdf. Acesso em: 17 Abr. 2013.

BRASIL. Diretrizes Curriculares Nacionais da Educação Básica. MEC. Brasília, 2013. Disponível

em: http://reitoria.ifpr.edu.br/wpcontent/uploads/2014/06/diretrizes_educacao_basica_2013.pdf Acesso em: 2 Abr. 2014.

Instituto Nacional de Estudos e Pesquisas Educacionais - INEP, (1999). Exame Nacional do Ensino Médio: Documento Básico 2000. Brasília: INEP.

Orientações Curriculares Para o Ensino Médio. Linguagens, códigos e suas tecnologias / Secretaria de Educação Básica. - Brasília: Ministério da Educação, Secretaria de Educação Básica, 2006. 239 p. (Orientações curriculares para o ensino médio; volume 1) 
Parâmetros Curriculares Nacionais + Ensino Médio - Orientações Educacionais Complementares aos Parâmetros Curriculares Nacionais. Disponível em: http://portal.mec.gov.br/seb/arquivos/pdf/linguagens02.pdf Acesso em: 5 Abr. 2014.

. Parâmetros Curriculares Nacionais - Ensino Médio, Bases Legais. 2000. Acesso em: 8 Mar. 2013.

- Parâmetros Curriculares Nacionais - Introdução. Ministério da Educação e do Desporto, Secretaria de Educação Fundamental. Brasília 1997. Acesso em: 8 Mar. 2013.

Pesquisa Nacional por Amostra de Domicílios. Acesso à Internet e Posse de Telefone móvel celular para uso Pessoal 2011. Rio de Janeiro 2013 (p.34) Ministério do Planejamento e Gestão - Instituto Brasileiro de Geografia e Estatística - IBGE. Disponível em: ftp://ftp.ibge.gov.br/Acesso_a_internet_e_posse_celular/2011/PNAD_Inter_2011.pdf

Portal do Professor do MEC. Disponível em:

http://portaldoprofessor.mec.gov.br/index.html. Acessos permanentes de Nov. 2012 a Dez.. 2014.

CASTELlS, M. A sociedade em rede. São Paulo: Paz e Terra, 2000. Conselho Nacional de Desenvolvimento Científico e Tecnológico. Sociedade da Informação. Brasília, 1999. 48p.

CELLARD, André. A análise documental. In: POUPART, Jean; Et al. A pesquisa qualitativa: Enfoques epistemológicos e metodológicos. Petrópolis: Vozes, 2008.

CETIC.br - Centro de Estudos sobre as Tecnologias da Informação e da Comunicação; CGI.br - Comitê Gestor da Internet no Brasil; NIC.br - Núcleo de Informação e Coordenação do Ponto BR. Pesquisa TIC Educação 2013: Pesquisa sobre o uso das tecnologias de informação e comunicação nas escolas brasileiras, São Paulo: UNESCO CETIC.br, 2014. Disponível em http://eproinfo.mec.gov.br/webfolio/Mod89005/tic_educacao_2013.pdf Acesso em: 1 Sep. 2014.

COLOMBIA. Colombia aprende. Disponível em: http://www.colombiaaprende.edu.co/html/home/1592/w3-channel.html. Acesso em: 30 Jan. 2013.

Comunidade REA Brasil. Disponível em: http://www.rea.net.br/site/comunidade-rea-brasil/ Acessos permanentes de Jan. 2013 a Dez.. 2014.

CNPQ. Disponível em: http://www.cnpq.br/ Acessos em: 30 Jan. 10 Jun. 2013.

CUMBRE MUNDIAL SOBRE LA SOCIEDAD DE LA INFORMACIÓN. La revolución digital. Ginebra2003-Túnez 2005. Disponível em: http://www.itu.int/wsis/basic/why-es.html 2005 http://www.itu.int/wsis/basic/about-es.html http://www.itu.int/wsis/stocktaking/docs/reports/S-POL-WSIS.REP-2012-PDF-E.pdf

CUMBRE MUNDIAL SOBRE LA SOCIEDAD DE LA INFORMACIÓN Compromiso de Tunez. Ginebra 2003-Túnez 2005 http://www.itu.int/wsis/docs2/tunis/off/7-es.pdf. Acesso em: 25 Jun. 2013. 
DELORS, Jacks, in UNESCO. La Educación Encierra un Tesoro: Compendio. Santillana Ediciones UNESCO. Disponível em http://www.unesco.org/education/pdf/DELORS_S.PDF. Acesso em: 30 Jan. 2013.

DOCUMENTO FINAL, OEI. 2021 Metas educativas: La educación que queremos para la generación de los bicentenarios. España: OEI, 2010. Disponível em http://www.oei.es/metas2021.pdf. Último acesso 10/06/2013.

DOCUMENTO FINAL. Cúpula Mundial sobre a Sociedade da Informação (CMSI) (CMSI, 2003, 2005) disponível em http://www.oei.es/metas2021.pdf ultimo acesso $10 / 06 / 2013$

DRUCKER, Peter. The age discontinuity, guidelines to our changing society. New York: Harper \& Row, 1969.

ENLACES. Disponível em: http://ineverycrea.net/comunidad/ineverycrea/recurso/DesdeChile-ENLACES-el-programa-integral-de-incl/18267ead-164c-43ac-a6c7-1cec2d21345c.

Acesso em: 30 Jan. 2013.

FIGUEIREDO, S. L. F. Considerações sobre a pesquisa em educação musical. In: FREIRE, Vanda Bellard (org.). Horizontes da pesquisa em música. Rio de Janeiro: 7Letras, 2010.

FLICK, Uwe. Desenho da pesquisa qualitativa: Coleção pesquisa qualitativa. São Paulo: Artemed, 2009.

Introdução à pesquisa qualitativa. $3^{\mathrm{a}}$ Ed. Porto Alegre: Artemed, 2009.

FRANCO, Maria Silvana; PECHIN, Claudia Azucena. Representaciones sociales de los/las estudiantes en la Formación Docente acerca de las áreas Música y Educación Física. In: Anuario No 4, 2002 (pp.39-50) - Facultad de Ciencias Humanas - Universidad Nacional de La Pampa - UNLPam. Disponível em: http://www.biblioteca.unlpam.edu.ar/pubpdf/anuario_fch/n04a03franco.pdf Acesso em: 13 Jul. 2014.

GARCÍA PÉREZ, Francisco F. Los modelos didácticos como instrumento de análisis y de intervención en la realidad educativa. In: 207. 18 de febrero de 2000 Biblio 3W Revista Bibliográfica de Geografía y Ciencias Sociales (Serie documental de Geo Crítica), Volumen $\mathrm{V}, \quad 2000, \mathrm{n}^{\mathrm{o}} 193 \quad-\mathrm{n}^{\mathrm{o}}$ 264. Universidad de Barcelona. Disponível em: http://www.ub.edu/geocrit/bw-5.htm. Acesso em: Abr. de 2014.

GUTTMAN, C. Education in and for the information society. Paris: UNESCO, Disponível em: 2003. http://unesdoc.unesco.org/images/0013/001355/135528e.pdf Acesso em: 21 Mai. 2013.

HARGREAVES, Andy. O ensino na sociedade do conhecimento. Educação na era da insegurança. Porto Alegre, SP: Artemed, 2004.

HABEYCHE, Candice Campos. Comunicação, Informação e Conhecimento: uma (re)leitura dos weblogs educacionais/profissionais do Portal do Professor. 01/03/2011 1v. 
200p. Mestrado. Pontifícia Universidade Católica do Rio Grande do Sul - Comunicação Social.

HENTSCHKE, Liane. A teoria espiral de Swanwick com fundamentação para uma proposta curricular. . In: V Encontro Anual da ABEM, 1996, Londrina. Anais do V Encontro Anual da ABEM. Londrina : ABEM, 1996. p. 171-185.

HENTSCHKE, Liane; DEL BEM, Luciana. Aula de música: Do planejamento e avaliação à prática educativa. In: HENTSCHKE, Liane; DEL BEM, Luciana (org.). Ensino de música. Propostas para pensar e agir em sala de aula. São Paulo: Moderna, 2003.

IMBERNÓN, Francisco. La programación de las tareas del aula: un proceso contextual, dinámico y flexible. In ANTUNES, S.; IBERNÓN, F.; DEL CARMEN, L. D.; PARCERISA, A.; ZABALA, A.; Del proyecto educativo a la programación de aula. Ed.10. Barcelona: Graó, 2008.

INAMORATO, Andreia dos Santos. Educação aberta: histórico, práticas e o contexto dos recursos educacionais abertos. In: Recursos Educacionais Abertos: práticas colaborativas políticas públicas - 1. ed., 1 imp. - Salvador: Edufba; São Paulo: Casa da Cultura Digital 2012.

Recursos educacionais abertos no Brasil: O estado da arte, desafios e perspectivas para o desenvolvimento e a inovação. São Paulo: cetic.br, 2013. Disponível em: http://pt.slideshare.net/inamor/recursos-educacionais-abertos-no-brasil-o-estado-da-artedesafios-e-perspectivas-para-o-desenvolvimento-e-inovaao Acesso em: 21 Abr. 2014.

JORQUERA, María Cecilia Jaramillo. Educación musical: Aportes para su comprensión a partir del origen de la disciplina. Revista Internacional de Investigación e Innovación Escolar V.58, p. 69-78, 2006, Diada editora

Modelos didácticos en la enseñanza musical: el caso de la escuela española. Revista Musical Chilena, Año LXIV, Julio-Diciembre, 2010, № 214, pp. 52-74.

KRAEMER, Rudolf - Dieter. Dimensões e funções do conhecimento pedagógico-musical. Em Revista EM PAUTA V.11, N¹6 / 17 Abril/Novembro 2000.

KRÜGER, Susana Ester. A percepção de docentes sobre a formação continuada em educação musical, apoiada pela educação a distância em um contexto orquestral. (2010) Tese (Doutorado). Educação. Pontifícia Universidade Católica de São Paulo (PUC-SP).

Educação musical apoiada pelas novas tecnologias de informação e comunicação (TIC): pesquisas, práticas e formação de docentes. Em Revista ABEM N 14 Março 2006 Art.8.

LAVILLE, Christian; DIONNE, Jean. A construção do saber: manual de metodologia da pesquisa em ciências humanas. Belo Horizonte: Artmed, (1999) 2008.

LÈVY, Pierre. A inteligência possível do século XXI. Revista Famecos, Porto Alegre, n.33, p. 13-20, 2007. 
Cibercultura. 2. Ed. São Paulo: Ed. 34, 2000.

. O que é o virtual? 1. Ed. São Paulo: Ed. 34, 1996.

A inteligência coletiva. 5. Ed. São Paulo: Loyola, 2007.

LIBÂNEO, José Carlos. Pedagogia e pedagogos, para quê? São Paulo: Cortez, 2012.

LIZARAZO, Arias Diego (Coord.). Representaciones y significados de las tecnologías de la información y la comunicación (TIC) en la escuela Primaria y secundaria. Informe final. MÉXICO. Casa Abierta al Tiempo-UAM-SEP, 2009. Disponível em: http://www.hdt.gob.mx/hdt/assets/HDT/RepresentacionessignificadosUAM.pdf Acesso em: 1 Ag. 2014.

MANOVICH, Lev. El lenguaje de los nuevos medios de comunicación: la imagen en la era digital. Barcelona: Paidós, 2005.

MARTINS, José Paulo Junior. A Pesquisa nas ciencias humanas e sociais. In: Teoria e prática da pesquisa aplicada. ISBN 978-85-352-5087-9 (recurso eletrônico). Elsevier editora Ltda. 2012 Dulce Mantella Perdigäo; Herlinger, Maximiliano; White, Oriana Monarca. (Orgs)

MATHEUS, Carlos Eduardo Meireles. Filosofía da pesquisa. In: Teoria e prática da pesquisa aplicada.ISBN 978-85-352-5087-9 (recurso eletrônico). Elsevier editora Ltda. 2012 Dulce Mantella Perdigäo; Herlinger, Maximiliano; White, Oriana Monarca. (Orgs)

MERCADO, Luis Paulo Leopoldo. Formação continuada de professores e novas tecnologias. Edufal, Maceió, AL. 1999.

MINDLIN, Sérgio E. Uma escrita em muitas mãos. Caderno de Orientações Didáticas Ler e Escrever Tecnologias na Educação. Disponível em: http://portalsme.prefeitura.sp.gov.br/Documentos/BibliPed/InfoEduc/caderno_impresso.pdf

OCDE, Centro de Nuevas Iniciativas. El conocimiento libre y los recursos educativos abiertos. Junta de Extremadura, España: OCDE, 2008. Disponível em: http://www.oecd.org/spain/42281358.pdf Acesso em: 1 Dez. 2013.

OLIVEIRA, M. M. Como fazer pesquisa qualitativa. Petrópolis, Vozes, 2007.

PASSARELLI, Brasilima. Interfaces digitais na educação: Alucin[ações] consentidas \& @ ções comedidas. São Paulo: USP-Escola do Futuro, 2007.

PINTO, Molina María. Introducción al análisis documental y sus niveles: el análisis de contenido. In: B. Anabad, XXXIX, núm.2, pp.323 - 341. España, Dialnet-Unirioja, 1989. Disponível em: http://dialnet.unirioja.es/descarga/articulo/798857.pdf

PRETTO, N. Redes colaborativas, ética hacker e educação. Educaçåo em Revista, v. 26, n. 3, p. 305-316, 2010. Disponível em: http://www.scielo.br/scielo.php?script=sci_arttext\&pid=S0102-46982010000300015 
PRIOR, Lindsay. Basic themes: use, production and Content. In: Using documents in social research. SAGE Publications, London. 2003

RELPE Rede Latino-americana de Portais educacionais. Disponível em: http://www.relpe.org/ Acessos permanentes de Jan. 2013 a Dez.. 2014.

ROSSINI, Carolina. (2010). Green-Paper: The State and Challenges of OER in Brazil: From Readers to Writers? The Berkman Center for Internet \& Society at Harvard University, Research Publication No. 2010-01, Disponível em: http://papers.ssrn.com/sol3/papers.cfm?abstract_id=1549922 Acesso em: 10 Jun. 2013.

ROSSINI, Carolina; GONZALEZ Cristiana. REA: o debate em política pública e as oportunidades para o mercado. In: Recursos Educacionais Abertos: práticas colaborativas políticas públicas - 1. ed., 1 imp. - Salvador: Edufba; São Paulo: Casa da Cultura Digital 2012. Disponível em: http://www.livrorea.net.br/livro/home.html. Acessos permanentes de Jan. 2013 a Dez.. 2014.

SACRISTÁN, J. Gimeno; PÉREZ, Gómez, A. I. Compreender e transformar o ensino. Porto Alegre: Artemed, 2000.

SANTANA, Bianca; ROSSINI, Carolina; PRETTO, De Lucca Nelson (Organizadores). Recursos Educacionais Abertos: práticas colaborativas políticas públicas - 1. ed., 1 imp. Salvador: Edufba; São Paulo: Casa da Cultura Digital 2012. Disponível em: http://www.livrorea.net.br/livro/home.html. Acessos permanentes de Jan. 2013 a Dez.. 2014.

SILVA, Jackson Ronie Sá; DOMINGOS, Cristóvão de Almeida; GUINDANI, Joel Felipe. Pesquisa documental: pistas teóricas e metodológicas. In: Revista Brasileira de História \& Ciências Sociais Ano I - Número I - Julho de 2009. ISSN: 2175-3423.

SILVA, Valdirene Moura; SILVA, Rejane Dias. Tecnologia da educação: as representações sociais dos professores de matemática da rede pública estadual do agreste. XVI ENDIPE - Encontro Nacional de Didática e Práticas de Ensino. Livro 2, p.007321. Campinas UNICAMP, 2012 Junqueira \& Marin Editores.

SILVEIRA, Sergio Amadeu da. Formatos abertos. In: SANTANA, Bianca; et al. Recursos Educacionais Abertos: práticas colaborativas e políticas públicas. 1. ed., 1 imp. - Salvador: Edufba; São Paulo: Casa da Cultura Digital 2012. Disponível em:

STEHR, Nico. Knowledge societies: the transformation of labour, property and knowledge in contemporary society. London: Sage, 1994.

SWANWICK, Keith. Música, mente y educación. Madrid: Morata, 1991.

Reflection, theory and practice. British Journal of Music Education, 25, doi:10.1017/S026505170800805X, 2008, pp 223-232. 
; SANTIAGO Diana (Trad.). Permanecendo fiel à música. In: II Encontro anual da ABEM. 1993, pp. 19-32.

TRIVIÑOS, Augusto N. S. Introdução a pesquisa em ciências sociais: a pesquisa qualitativa em educação. Säo Paulo: Atlas, 2012.

UNESCO, Informe Final. Forum on the Impact of Open Courseware for Higher Education in Developing Countries, UNESCO. Paris, 1-3 Jul. 2002. Disponível em: http://unesdoc.unesco.org/images/0012/001285/128515e.pdf Acesso em: 17 Jun. 2013.

Informe mundial de la. Hacia las sociedades del conocimiento, Paris, 2005.

Disponível em: http://unesdoc.unesco.org/images/0014/001419/141908s.pdf. Acesso em: 21 Mai. 2013.

Taking OER beyond the OER Community. Disponível em: http://oerworkshop.weebly.com/guidelines-for-oer-in-higher-education.html ano?

VEIGA, Ilma, Passos, Alencastro. Organização didática da aula: um projeto colaborativo de ação imediata. In VEIGA, Ilma, Passos, Alencastro (Org.) Aula: Gênese, dimensões, princípios e práticas. Campinas: Papirus, 2008.

WAISELFISZ, Julio Jacobo. Lápis,borracha e teclado: tecnologia da informação na educação. Brasil e America Latina. Ritla-MEC-Instituto Sangari, Bsb, 2007

WEBSTER, R. Peter. Computer-Based technology and Music Teaching and Learning. In: COLWELL, R. (Ed.). Handbook of Research on Music Teaching and Learning. Oxford: University Press, 2002. 


\section{APÊNDICE A - Primeira seleção de aulas de música do Portal do professor. Seleção intencional das 10 primeiras aulas de cada TEMA}

"Mais opções de busca":

TIPO DE PESQUISA: Ensino Médio / COMPONENTE CURRICULAR: Artes

TEMA: Música: Canal. Música: Contextualização. Música: Estruturas sintáticas: Música: Estruturas morfológicas. / UF: Todos

ORDEM DE CLASIFICAÇÃO: Mais comentadas. Melhor classificadas. Mais acessadas

\begin{tabular}{|c|c|c|c|}
\hline \multicolumn{4}{|c|}{ Canal } \\
\hline & Mais comentadas & Melhor classificadas & Mais acessadas \\
\hline 1 & Nas ondas do rádio & A ponte & $\begin{array}{l}\text { Conceitos de música: ritmo, } \\
\text { melodia e harmonia - aula } 3\end{array}$ \\
\hline 2 & A ponte & $\begin{array}{l}\text { MÚSICA - Oficina 2: composição } \\
\text { com nomes ou outros termos. }\end{array}$ & $\begin{array}{l}\text { PARTITURA MUSICAL - } \\
\text { Pauta, Claves, e Notas Musicais }\end{array}$ \\
\hline 3 & $\begin{array}{l}\text { MÚSICA - escrita e leitura } \\
\text { musical: pulso, pulsação, som, } \\
\text { unidade de tempo, silêncio (aula } \\
\text { 1) }\end{array}$ & $\begin{array}{l}\text { Música - uma proposta de Aula } \\
\text { Introdutória no contexto da EJA } \\
\text { (aula 1) }\end{array}$ & $\begin{array}{l}\text { Música: Elementos de expressão } \\
\text { e caráter - interpretação }\end{array}$ \\
\hline 4 & $\begin{array}{l}\text { Conceitos de música: ritmo, } \\
\text { melodia e harmonia - aula } 3\end{array}$ & $\begin{array}{l}\text { Música - Garrafas PET como } \\
\text { percussão afinada - aula } 2\end{array}$ & $\begin{array}{l}\text { MÚSICA - escrita e leitura } \\
\text { musical: pulso, pulsação, som, } \\
\text { unidade de tempo, silêncio (aula } \\
\text { 1) }\end{array}$ \\
\hline 5 & $\begin{array}{l}\text { MÚSICA - Oficina } 1 \text { - } \\
\text { Instrumento musical humano: um } \\
\text { exercício de criatividade e } \\
\text { composição }\end{array}$ & $\begin{array}{l}\text { Música - Garrafas PET como } \\
\text { percussão afinada - aula } 3\end{array}$ & $\begin{array}{l}\text { Música - Canto coletivo na } \\
\text { África do Sul (aula 02): } \\
\text { "Tchotcholôsa", um canto de } \\
\text { trabalho }\end{array}$ \\
\hline 6 & $\begin{array}{l}\text { Música - Canto coletivo na } \\
\text { África do Sul (aula 02): } \\
\text { "Tchotcholôsa", um canto de } \\
\text { trabalho }\end{array}$ & $\begin{array}{l}\text { Música - Canto coletivo na África } \\
\text { do Sul (aula 01): "Isicathamiya" e } \\
\text { o grupo Ladysmith Black } \\
\text { Mambazo }\end{array}$ & $\begin{array}{l}\text { MUSICA - Percussäo corporal: } \\
\text { Mäos }\end{array}$ \\
\hline 7 & $\begin{array}{l}\text { MÚSICA: Construção de } \\
\text { instrumento musical - berimbau } \\
\text { de caniço }\end{array}$ & $\begin{array}{l}\text { Música - Canto coletivo na África } \\
\text { do Sul (aula 02): "Tchotcholôsa", } \\
\text { um canto de trabalho }\end{array}$ & $\begin{array}{l}\text { MÚSICA - Oficina } 1 \text { - } \\
\text { Instrumento musical humano: um } \\
\text { exercício de criatividade e } \\
\text { composição }\end{array}$ \\
\hline 8 & $\begin{array}{l}\text { Dança de Salão: Introdução ao } \\
\text { Forró }\end{array}$ & $\begin{array}{l}\text { MÚSICA - Oficina 6: Melodia e } \\
\text { Acompanhamento }\end{array}$ & A ponte \\
\hline 9 & Paisagem Sonora & MÚSICA: Composição - Variação & $\begin{array}{l}\text { MUSICA - Percussão corporal - } \\
\text { Tronco }\end{array}$ \\
\hline 10 & Uma orquestra diferente & $\begin{array}{l}\text { Conceitos de música: ritmo, } \\
\text { melodia e harmonia - aula } 3\end{array}$ & $\begin{array}{l}\text { Música - Jogos musicais com } \\
\text { percussão corporal: percepção de } \\
\text { ritmo - aula } 5\end{array}$ \\
\hline
\end{tabular}

Aulas Repetidas nas categorias mais comentadas, melhor classificadas, mais acessadas - MUSICA: Canal

\begin{tabular}{|c|c|c|c|}
\hline Total & & & 3 \\
\hline Aulas & $\begin{array}{c}\text { A } \\
\text { ponte }\end{array}$ & $\begin{array}{l}\text { Conceitos de música: ritmo, } \\
\text { melodia e harmonia - aula } 3\end{array}$ & $\begin{array}{l}\text { Música - Canto coletivo na África do Sul (aula 02): } \\
\text { "Tchotcholôsa", um canto de trabalho }\end{array}$ \\
\hline
\end{tabular}




\begin{tabular}{|c|c|c|c|}
\hline \multicolumn{4}{|c|}{ Contextualização } \\
\hline & Mais comentadas & Melhor classificadas & Mais acessadas \\
\hline 1 & Nas ondas do rádio & A ponte & $\begin{array}{l}\text { Conceitos de música: } \\
\text { ritmo, melodia e harmonia } \\
\text { - aula } 3\end{array}$ \\
\hline 2 & $\begin{array}{l}\text { A Escravidão Negra: da África ao } \\
\text { Brasil }\end{array}$ & $\begin{array}{l}\text { MÚSICA - Oficina 2: composição } \\
\text { com nomes ou outros termos. }\end{array}$ & $\begin{array}{l}\text { A música brasileira e a } \\
\text { ditadura militar }\end{array}$ \\
\hline 3 & Fractais & $\begin{array}{l}\text { Música - uma proposta de Aula } \\
\text { Introdutória no contexto da EJA (aula } \\
\text { 1) }\end{array}$ & $\begin{array}{l}\text { A Escravidão Negra: da } \\
\text { África ao Brasil }\end{array}$ \\
\hline 4 & Música para que? & $\begin{array}{l}\text { Música - Garrafas PET como } \\
\text { percussão afinada - aula } 2\end{array}$ & Fractais \\
\hline 5 & A ponte & $\begin{array}{l}\text { Música - Garrafas PET como } \\
\text { percussão afinada - aula } 3\end{array}$ & Música para que? \\
\hline 6 & $\begin{array}{l}\text { MÚSICA - escrita e leitura musical: } \\
\text { pulso, pulsação, som, unidade de } \\
\text { tempo, silêncio (aula 1) }\end{array}$ & $\begin{array}{l}\text { Música - Canto coletivo na África do } \\
\text { Sul (aula 01): "Isicathamiya" e o } \\
\text { grupo Ladysmith Black Mambazo }\end{array}$ & $\begin{array}{l}\text { Música: Elementos de } \\
\text { expressão e caráter - } \\
\text { interpretação }\end{array}$ \\
\hline 7 & $\begin{array}{l}\text { Conceitos de música: ritmo, melodia } \\
\text { e harmonia - aula } 3\end{array}$ & $\begin{array}{l}\text { Música - Canto coletivo na África do } \\
\text { Sul (aula 02): “Tchotcholôsa”, um } \\
\text { canto de trabalho }\end{array}$ & $\begin{array}{l}\text { MÚSICA - escrita e } \\
\text { leitura musical: pulso, } \\
\text { pulsação, som, unidade de } \\
\text { tempo, silêncio (aula 1) }\end{array}$ \\
\hline 8 & $\begin{array}{l}\text { MÚSICA - Oficina } 1 \text { - Instrumento } \\
\text { musical humano: um exercício de } \\
\text { criatividade e composição }\end{array}$ & História do Samba & $\begin{array}{l}\text { MUSICA POPULAR } \\
\text { BRASILEIRA - A } \\
\text { Constituição dos } \\
\text { Primeiros Ritmos } \\
\text { Brasileiros }\end{array}$ \\
\hline 9 & $\begin{array}{l}\text { Música - Pedal e Ostinato, uma } \\
\text { experiência de composição com } \\
\text { alunos em sala de aula - aula } 01\end{array}$ & $\begin{array}{l}\text { MÚSICA - Oficina 6: Melodia e } \\
\text { Acompanhamento }\end{array}$ & $\begin{array}{l}\text { Música - Canto coletivo } \\
\text { na África do Sul (aula 02): } \\
\text { "Tchotcholôsa", um canto } \\
\text { de trabalho }\end{array}$ \\
\hline 10 & $\begin{array}{l}\text { Música - Canto coletivo na África do } \\
\text { Sul (aula 02): "Tchotcholôsa", um } \\
\text { canto de trabalho }\end{array}$ & MÚSICA: Composição - Variação & $\begin{array}{l}\text { MUSICA - Percussão } \\
\text { corporal: Mãos }\end{array}$ \\
\hline
\end{tabular}

Aulas Repetidas nas categorias mais comentadas, melhor classificadas, mais acessadas - MUSICA: Contextualização

\begin{tabular}{|c|c|}
\hline Total & 1 \\
\hline & Música - Canto coletivo na África do Sul (aula 02): "Tchotcholôsa", um canto de trabalho \\
\hline
\end{tabular}

\begin{tabular}{|l|l|l|l|}
\hline \multicolumn{4}{|c|}{ ESTRUTURAS SINTÁTICAS } \\
\hline 1 & \multicolumn{1}{|c|}{ Mais comentadas } & \multicolumn{1}{|c|}{ Melhor classificadas } & \multicolumn{1}{c|}{ Mais acessadas } \\
\hline 2 & $\begin{array}{l}\text { MÚSICA - escrita e leitura musical: } \\
\text { pulso, pulsação, som, unidade de } \\
\text { tempo, silêncio (aula 1) }\end{array}$ & $\begin{array}{l}\text { MÚSICA - Oficina 2: } \\
\text { composição com nomes ou } \\
\text { outros termos. }\end{array}$ & $\begin{array}{l}\text { Conceitos de música: ritmo, } \\
\text { melodia e harmonia - aula 3 }\end{array}$ \\
\hline
\end{tabular}




\begin{tabular}{|c|c|c|c|}
\hline 3 & $\begin{array}{l}\text { Conceitos de música: ritmo, melodia e } \\
\text { harmonia - aula } 3\end{array}$ & $\begin{array}{l}\text { Música - Garrafas PET como } \\
\text { percussão afinada - aula } 2\end{array}$ & $\begin{array}{l}\text { MÚSICA - escrita e leitura } \\
\text { musical: pulso, pulsação, som, } \\
\text { unidade de tempo, silêncio (aula } \\
\text { 1) }\end{array}$ \\
\hline 4 & $\begin{array}{l}\text { MÚSICA - Oficina } 1 \text { - Instrumento } \\
\text { musical humano: um exercício de } \\
\text { criatividade e composição }\end{array}$ & $\begin{array}{l}\text { Música - Garrafas PET como } \\
\text { percussão afinada - aula } 3\end{array}$ & $\begin{array}{l}\text { Música - Canto coletivo na } \\
\text { África do Sul (aula 02): } \\
\text { "Tchotcholôsa", um canto de } \\
\text { trabalho }\end{array}$ \\
\hline 5 & $\begin{array}{l}\text { Música - Pedal e Ostinato, uma } \\
\text { experiência de composição com alunos } \\
\text { em sala de aula - aula } 01\end{array}$ & $\begin{array}{l}\text { Música - Canto coletivo na } \\
\text { África do Sul (aula 01): } \\
\text { "Isicathamiya" e o grupo } \\
\text { Ladysmith Black Mambazo }\end{array}$ & $\begin{array}{l}\text { MUSICA - Percussão corporal: } \\
\text { Mãos }\end{array}$ \\
\hline 6 & $\begin{array}{l}\text { Música - Canto coletivo na África do } \\
\text { Sul (aula 02): "Tchotcholôsa", um } \\
\text { canto de trabalho }\end{array}$ & $\begin{array}{l}\text { Música - Canto coletivo na } \\
\text { África do Sul (aula 02): } \\
\text { "Tchotcholôsa", um canto de } \\
\text { trabalho }\end{array}$ & $\begin{array}{l}\text { MÚSICA - Oficina } 1 \text { - } \\
\text { Instrumento musical humano: } \\
\text { um exercício de criatividade e } \\
\text { composição }\end{array}$ \\
\hline 7 & $\begin{array}{l}\text { MÚSICA: Construção de instrumento } \\
\text { musical - berimbau de caniço }\end{array}$ & $\begin{array}{l}\text { MÚSICA - Oficina 6: } \\
\text { Melodia e Acompanhamento }\end{array}$ & A ponte \\
\hline 8 & $\begin{array}{l}\text { Literando: Carlos Drummond de } \\
\text { Andrade }\end{array}$ & $\begin{array}{l}\text { MÚSICA: Composição - } \\
\text { Variação }\end{array}$ & Percussão corporal - Tronco \\
\hline 9 & Uma orquestra diferente & $\begin{array}{l}\text { Literando: Carlos Drummond } \\
\text { de Andrade }\end{array}$ & $\begin{array}{l}\text { Literando: Carlos Drummond } \\
\text { de Andrade }\end{array}$ \\
\hline 10 & $\begin{array}{l}\text { MÚSICA - escrita e leitura musical: } \\
\text { dominó com figuras musicais (aula 3) }\end{array}$ & $\begin{array}{l}\text { Conceitos de música: ritmo, } \\
\text { melodia e harmonia - aula } 3\end{array}$ & $\begin{array}{l}\text { MÚSICA - escrita e leitura } \\
\text { musical: compasso (aula 2) }\end{array}$ \\
\hline
\end{tabular}

\begin{tabular}{|c|c|c|c|c|}
\hline \multicolumn{5}{|c|}{ Aulas comuns - MUSICA: Estruturas sintáticas } \\
\hline Total & A ponte & $\begin{array}{c}\text { Conceitos de música: } \\
\text { ritmo, melodia e } \\
\text { harmonia - aula 3 }\end{array}$ & $\begin{array}{c}\text { Música - Canto } \\
\text { coletivo na África do } \\
\text { Sul (aula 02): } \\
\text { "Tchotcholôsa", um } \\
\text { canto de trabalho }\end{array}$ & $\begin{array}{c}\text { Literando: Carlos } \\
\text { Drummond de Andrade }\end{array}$ \\
\hline
\end{tabular}

\begin{tabular}{|c|c|c|c|}
\hline \multicolumn{4}{|c|}{ ESTRUTURAS MORFOLÓGICAS } \\
\hline & Mais comentadas & Melhor classificadas & Mais acessadas \\
\hline 1 & A ponte & A ponte & $\begin{array}{l}\text { Conceitos de música: ritmo, } \\
\text { melodia e harmonia - aula } 3\end{array}$ \\
\hline 2 & $\begin{array}{l}\text { MÚSICA - escrita e leitura } \\
\text { musical: pulso, pulsação, som, } \\
\text { unidade de tempo, silêncio (aula 1) }\end{array}$ & $\begin{array}{l}\text { MÚSICA - Oficina } 2 \text { : } \\
\text { composição com nomes ou outros } \\
\text { termos. }\end{array}$ & $\begin{array}{l}\text { Música: Elementos de } \\
\text { expressão e caráter - } \\
\text { interpretação }\end{array}$ \\
\hline 3 & $\begin{array}{l}\text { Conceitos de música: ritmo, } \\
\text { melodia e harmonia - aula } 3\end{array}$ & $\begin{array}{l}\text { Música - Canto coletivo na } \\
\text { África do Sul (aula 01): } \\
\text { "Isicathamiya" e o grupo } \\
\text { Ladysmith Black Mambazo }\end{array}$ & $\begin{array}{l}\text { MÚSICA - escrita e leitura } \\
\text { musical: pulso, pulsação, som, } \\
\text { unidade de tempo, silêncio (aula } \\
\text { 1) }\end{array}$ \\
\hline 4 & $\begin{array}{l}\text { MÚSICA - Oficina } 1 \text { - Instrumento } \\
\text { musical humano: um exercício de } \\
\text { criatividade e composição }\end{array}$ & $\begin{array}{l}\text { Música - Canto coletivo na } \\
\text { África do Sul (aula 02): } \\
\text { "Tchotcholôsa", um canto de } \\
\text { trabalho }\end{array}$ & $\begin{array}{l}\text { Música - Canto coletivo na } \\
\text { África do Sul (aula 02): } \\
\text { "Tchotcholôsa", um canto de } \\
\text { trabalho }\end{array}$ \\
\hline 5 & $\begin{array}{l}\text { Música - Pedal e Ostinato, uma } \\
\text { experiência de composição com } \\
\text { alunos em sala de aula - aula } 01\end{array}$ & $\begin{array}{l}\text { MÚSICA - Oficina 6: Melodia e } \\
\text { Acompanhamento }\end{array}$ & $\begin{array}{l}\text { MUSICA - Percussão corporal: } \\
\text { Mãos }\end{array}$ \\
\hline
\end{tabular}




\begin{tabular}{|c|c|c|c|}
\hline 6 & $\begin{array}{l}\text { Música - Canto coletivo na África } \\
\text { do Sul (aula 02): "Tchotcholôsa", } \\
\text { um canto de trabalho }\end{array}$ & $\begin{array}{l}\text { MÚSICA: Composição - } \\
\text { Variação }\end{array}$ & $\begin{array}{l}\text { MÚSICA - Oficina } 1 \text { - } \\
\text { Instrumento musical humano: } \\
\text { um exercício de criatividade e } \\
\text { composição }\end{array}$ \\
\hline 7 & $\begin{array}{l}\text { MÚSICA: Construção de } \\
\text { instrumento musical - berimbau de } \\
\text { caniço }\end{array}$ & $\begin{array}{l}\text { Conceitos de música: ritmo, } \\
\text { melodia e harmonia - aula } 3\end{array}$ & A ponte \\
\hline 8 & Uma orquestra diferente & $\begin{array}{l}\text { MÚSICA: Elementos de } \\
\text { expressão - legato e staccato }\end{array}$ & Percussão corporal - Tronco \\
\hline 9 & $\begin{array}{l}\text { MÚSICA - escrita e leitura } \\
\text { musical: dominó com figuras } \\
\text { musicais (aula 3) }\end{array}$ & $\begin{array}{l}\text { MÚSICA: Elementos de } \\
\text { expressão (duração e andamento) } \\
\text { - Fermata }\end{array}$ & $\begin{array}{l}\text { MÚSICA - escrita e leitura } \\
\text { musical: compasso (aula 2) }\end{array}$ \\
\hline 10 & $\begin{array}{l}\text { MÚSICA - Oficina } 4 \text { - O universo } \\
\text { do DJ }\end{array}$ & $\begin{array}{l}\text { Conceitos de música - } \\
\text { composição e instrumento } \\
\text { musical não convencional - aula } 6\end{array}$ & $\begin{array}{l}\text { Conceitos de música - som, } \\
\text { silencio e ruído - paisagem } \\
\text { sonora - aula } 2\end{array}$ \\
\hline
\end{tabular}

\begin{tabular}{|c|c|c|c|}
\hline \multicolumn{3}{|c|}{ Aulas comuns - Estruturas morfológicas } \\
\hline Total & A ponte & 3 & Música - Canto coletivo na \\
Aulas & Conceitos de música: ritmo, \\
melodia e harmonia - aula 3 & $\begin{array}{c}\text { Áfo Sul (aula 02): } \\
\text { "Tchotcholôsa", um canto de } \\
\text { trabalho }\end{array}$ \\
\hline
\end{tabular}




\section{APÊNDICE B - Processo de Amostragem: organização das aulas da amostragem aleatória}

Número de início 5 e contagem sucessiva selecionando de 7 em 7 aulas; identificaramse e excluíram-se as aulas repetidas e na listagem é atribuída a cada aula selecionada um novo número de ordem.

Total Aulas de Música: 813 aulas para MUSICA, no Ensino Médio: 163 aulas.

Amostra tomada em Abril 1 de 2014

\begin{tabular}{|c|c|c|c|c|}
\hline $\begin{array}{l}\mathrm{N}^{\circ} \text { do } \\
\text { Portal }\end{array}$ & CANAL & CONTEXTUALIZAÇÃO & $\begin{array}{c}\text { ESTRUTURAS } \\
\text { MORFOLÓGICAS }\end{array}$ & $\begin{array}{l}\text { ESTRUTURAS } \\
\text { SINTÁTICAS }\end{array}$ \\
\hline 5 & $\begin{array}{l}\text { Música - Canto } \\
\text { coletivo na África } \\
\text { do Sul (aula 02): } \\
\text { "Tchotcholôsa", } \\
\underline{\text { um canto de }} \\
\underline{\text { trabalho }} \\
\underline{\mathbf{1}}\end{array}$ & Música para quê? & $\begin{array}{l}\text { MÚSICA - Percussão } \\
\underline{\text { corporal: Mãos }}\end{array}$ & $\begin{array}{l}\text { MÚSICA - Percussão } \\
\text { corporal: Mãos }\end{array}$ \\
\hline 12 & $\begin{array}{l}\frac{\text { MÚSICA - escrita }}{\text { e leitura musical: }} \\
\frac{\text { compasso (aula 2) }}{\underline{4}}\end{array}$ & $\begin{array}{l}\text { A ponte } \\
\underline{\mathbf{5}}\end{array}$ & $\begin{array}{l}\text { MÚSICA - Percussão } \\
\underline{\text { corporal: Composição }} \\
\underline{\text { aula 1) }} \\
\underline{\mathbf{6}}\end{array}$ & $\begin{array}{l}\text { MÚSICA - Percussão } \\
\text { corporal: Composição } \\
\underline{(\text { aula 1) }}\end{array}$ \\
\hline 19 & $\begin{array}{l}\frac{\text { Uma orquestra }}{\text { diferente }} \\
7\end{array}$ & $\begin{array}{l}\text { MÚSICA - escrita e leitura } \\
\text { musical: dominó com } \\
\text { figuras musicais (aula 3). } \\
\underline{\mathbf{8}}\end{array}$ & $\begin{array}{l}\frac{\text { MÚSICA: Construção }}{\text { de instrumento musical }} \\
\frac{\text { - violão de caixa de }}{\text { sapato }} \\
\underline{\mathbf{9}}\end{array}$ & $\begin{array}{l}\text { MÚSICA: Construção } \\
\text { de instrumento musical } \\
\text { - violão de caixa de } \\
\underline{\text { sapato }}\end{array}$ \\
\hline 26 & $\begin{array}{l}\text { MÚSICA: } \\
\text { Construção de } \\
\text { instrumento } \\
\text { musical - violão de } \\
\text { caixa de sapato }\end{array}$ & $\begin{array}{l}\text { Tropicália: música, } \\
\text { comportamento e atitude } \\
\underline{\text { no Brasil da década de }} \\
\underline{1960} \\
\underline{\mathbf{1 0}}\end{array}$ & $\begin{array}{l}\text { MÚSICA - Percussão } \\
\text { corporal: Boca }\end{array}$ & $\begin{array}{l}\text { MÚSICA - Percussão } \\
\text { corporal: Boca }\end{array}$ \\
\hline
\end{tabular}




\begin{tabular}{|c|c|c|c|c|}
\hline $\begin{array}{l}\mathrm{N}^{\circ} \text { do } \\
\text { Portal }\end{array}$ & CANAL & CONTEXTUALIZAÇÃO & $\begin{array}{c}\text { ESTRUTURAS } \\
\text { MORFOLÓGICAS }\end{array}$ & $\begin{array}{l}\text { ESTRUTURAS } \\
\text { SINTÁTICAS }\end{array}$ \\
\hline 33 & $\begin{array}{l}\text { Música - Jogos } \\
\text { musicais com } \\
\text { percussão corporal: } \\
\text { percepção de ritmo } \\
\underline{\text { - aula 4 }} \\
\underline{\mathbf{1 2}}\end{array}$ & $\begin{array}{l}\text { O Funk carioca e sua } \\
\text { dinâmica social }\end{array}$ & $\begin{array}{l}\text { Música - Trilha sonora } \\
\text { - Projeto e Roteiro }\end{array}$ & $\begin{array}{l}\text { Música - Trilha sonora } \\
\text { - Projeto e Roteiro }\end{array}$ \\
\hline 40 & $\begin{array}{l}\text { MÚSICA- Oficina } \\
\text { 3: paisagem } \\
\underline{\text { sonora. }}\end{array}$ & $\begin{array}{l}\text { MÚSICA - Oficina 4-O } \\
\underline{\text { universo do DJ }}\end{array}$ & $\begin{array}{l}\frac{\text { MÚSICA - Percussão }}{\text { corporal: Composição }} \\
\underline{\text { (aula 2) }} \\
\underline{\mathbf{1 7}}\end{array}$ & $\begin{array}{l}\text { Música }- \text { Gumboot } \\
\text { Dancing, dança de } \\
\text { resistência das minas } \\
\text { da África do Sul - aula } \\
\underline{01} \\
\underline{\mathbf{1 8}}\end{array}$ \\
\hline 47 & $\begin{array}{l}\text { Música - criação } \\
\underline{\text { de canção: ritmo e }} \\
\text { gênero } \\
\underline{\mathbf{1 9}}\end{array}$ & $\begin{array}{l}\text { MÚSICA: Elementos de } \\
\text { expressão (andamento) - } \\
\underline{\text { accelerando e rallentando }} \\
\underline{\mathbf{2 0}}\end{array}$ & $\begin{array}{l}\text { MÚSICA: Composição } \\
\text { - Frase } \\
\underline{\mathbf{2 1}}\end{array}$ & $\begin{array}{l}\text { Música - Criação de } \\
\text { canção - "Estudando o } \\
\underline{\text { samba" (parte 2) }} \\
\underline{\mathbf{2 2}}\end{array}$ \\
\hline 54 & $\begin{array}{l}\text { MÚSICA: } \\
\text { Composição - } \\
\underline{\text { Elementos de }} \\
\underline{\text { Contraste }}\end{array}$ & $\begin{array}{l}\text { MÚSICA - Percussão } \\
\underline{\text { corporal: Composição }} \\
\underline{\text { (aula 2) }}\end{array}$ & $\begin{array}{l}\text { Música - Pedal e } \\
\text { Ostinato, uma } \\
\text { experiência de } \\
\text { composição com alunos } \\
\underline{\text { em sala de aula - aula }} \\
\underline{02} \\
\underline{\mathbf{2 4}}\end{array}$ & $\begin{array}{l}\frac{\text { Música - criação de }}{\text { canção: conceito - aula }} \\
\underline{1}\end{array}$ \\
\hline 61 & $\begin{array}{l}\text { MÚSICA: } \\
\text { Composição - } \\
\underline{\text { Frase }}\end{array}$ & $\begin{array}{l}\text { Música - Criação de } \\
\text { canção - "Estudando o } \\
\underline{\text { samba" (parte 2) }}\end{array}$ & $\begin{array}{l}\text { Música - criação de } \\
\text { canção: relação entre } \\
\text { texto, melodia e língua } \\
\underline{\mathbf{2 6}}\end{array}$ & $\begin{array}{l}\underline{\text { O Tom do Samba }} \\
\underline{\mathbf{2 7}}\end{array}$ \\
\hline 68 & $\begin{array}{l}\text { Dança de Salão: } \\
\underline{\text { Introdução ao }} \\
\underline{\text { Forró }} \\
\underline{\mathbf{2 8}}\end{array}$ & $\begin{array}{l}\text { Música - criação de } \\
\text { canção: conceito - aula } 1\end{array}$ & $\begin{array}{l}\text { Música - Matemúsicas - } \\
\underline{\text { Tempo }} \\
\underline{\mathbf{2 9}}\end{array}$ & $\begin{array}{l}\text { Música - Composição } \\
\underline{\text { Imagística (parte 1) }} \\
\underline{\mathbf{3 0}}\end{array}$ \\
\hline 75 & $\begin{array}{l}\frac{\text { Música }- \text { criação }}{\text { de canção: tema e }} \\
\underline{\text { forma }} \\
\underline{\mathbf{3 1}}\end{array}$ & $\begin{array}{l}\text { Música - Pedal e Ostinato, } \\
\text { uma experiência de } \\
\underline{\text { composição com alunos }} \\
\underline{\text { em sala de aula - aula } 02}\end{array}$ & $\begin{array}{l}\frac{\text { Música - Matemúsicas }}{- \text { Matriz (parte 2) }} \\
\underline{\mathbf{3 2}}\end{array}$ & $\begin{array}{l}\text { Música - Matemúsicas } \\
\text {-Altura }\end{array}$ \\
\hline
\end{tabular}




\begin{tabular}{|c|c|c|c|c|}
\hline $\begin{array}{l}\mathrm{N}^{\circ} \text { do } \\
\text { Portal }\end{array}$ & CANAL & CONTEXTUALIZAÇÃO & $\begin{array}{c}\text { ESTRUTURAS } \\
\text { MORFOLÓGICAS }\end{array}$ & $\begin{array}{l}\text { ESTRUTURAS } \\
\text { SINTÁTICAS }\end{array}$ \\
\hline 82 & $\begin{array}{l}\text { Música - } \\
\text { Composição } \\
\underline{\text { Imagística (parte 1) }}\end{array}$ & $\begin{array}{l}\text { MÚSICA: Composição - } \\
\underline{\text { Objeto Sonoro e Música }} \\
\underline{\text { Concreta }} \\
\underline{\mathbf{3 4}}\end{array}$ & $\begin{array}{l}\text { Música - Pedal e } \\
\text { Ostinato, uma } \\
\text { experiência de } \\
\text { composição com alunos } \\
\text { em sala de aula - aula } \\
\underline{05} \\
\underline{\mathbf{3 5}}\end{array}$ & $\begin{array}{l}\text { Música - Pedal e } \\
\text { Ostinato, uma } \\
\text { experiência de } \\
\underline{\text { composição com }} \\
\text { alunos em sala de aula } \\
\underline{\text { - aula } 04} \\
\underline{\mathbf{3 6}}\end{array}$ \\
\hline 89 & $\begin{array}{l}\text { Música - Recepção, } \\
\text { gosto e identidade - } \\
\text { segunda parte (aula } \\
\underline{5)} \\
\underline{37}\end{array}$ & $\begin{array}{l}\underline{\text { MÚSICA: Composição- }} \\
\underline{\text { Improvisação }} \\
\underline{\mathbf{3 8}}\end{array}$ & $\begin{array}{l}\frac{\text { Música - compassos }}{\text { ternários - Leitura e }} \\
\underline{\text { escrita } 3} \\
\underline{\mathbf{3 9}}\end{array}$ & $\begin{array}{l}\underline{\text { Música - Composição }} \\
\underline{\text { Imagística (parte 5) }} \\
\underline{\mathbf{4 0}}\end{array}$ \\
\hline 96 & $\begin{array}{l}\frac{\text { MÚSICA: }}{\text { Composição - }} \\
\frac{\text { Aleatoriedade }}{41} \\
\underline{41}\end{array}$ & $\begin{array}{l}\text { Música - O computador } \\
\text { como instrumento musical } \\
\underline{\text { (aula 2): Audacity, o início }} \\
\underline{\mathbf{4 2}}\end{array}$ & $\begin{array}{l}\text { Música - compassos } \\
\text { quaternários - Leitura e } \\
\underline{\text { escrita } 1} \\
\underline{\mathbf{4 3}}\end{array}$ & $\begin{array}{l}\text { Música - compassos } \\
\text { quaternários - Leitura } \\
\underline{\text { e escrita } 6} \\
\underline{44}\end{array}$ \\
\hline 103 & $\begin{array}{l}\text { Dança de salão: } \\
\underline{\text { Introdução ao }} \\
\underline{\text { Samba }} \\
\underline{\mathbf{4 5}}\end{array}$ & $\begin{array}{l}\text { Música - Pedal e Ostinato, } \\
\text { uma experiência de } \\
\text { composição com alunos } \\
\text { em sala de aula - aula } 04 \\
\end{array}$ & & \\
\hline 110 & $\begin{array}{l}\text { Música - } \\
\underline{\text { Expressividade - }} \\
\underline{\text { Contraste (parte 2) }} \\
\underline{\mathbf{4 6}}\end{array}$ & $\begin{array}{l}\text { Música - compassos } \\
\text { quaternários - Leitura e } \\
\text { escrita } 2 \\
\underline{47}\end{array}$ & & \\
\hline 117 & $\begin{array}{l}\overline{\text { Música - }} \\
\underline{\text { compassos }} \\
\text { ternários - Leitura } \\
\underline{\text { e escrita } 2} \\
\underline{\mathbf{4 8}}\end{array}$ & $\begin{array}{l}\text { Música - compassos } \\
\text { quaternários - Leitura e } \\
\text { escrita } 1\end{array}$ & & \\
\hline 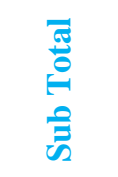 & 14 Aulas & 11 Aulas & 14 Aulas & 9 Aulas \\
\hline 馬 & \multicolumn{4}{|c|}{$\underline{N=48}$} \\
\hline
\end{tabular}




\section{APÊNDICE C - Planilha PB1}

Plarilha Componentes da sula observada tal como publicada no Portal do Professor

\begin{tabular}{|c|c|c|c|c|c|c|c|c|c|}
\hline \multicolumn{10}{|c|}{ Planilha-AULAS DO PORTAL DO PROFESSOR } \\
\hline & & & & & & 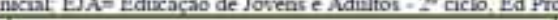 & & & \\
\hline $\begin{array}{c}N^{2} \\
a b a\end{array}$ & TITLO & AUTOR & INSTITUICĀO & $\begin{array}{l}\text { MODAII } \\
\text { DADENI } \\
\text { VEI. DE } \\
\text { ENSINO }\end{array}$ & $\begin{array}{c}\text { COMPON } \\
\text { ENTE } \\
\text { CURRIC } \\
\text { U.AR }\end{array}$ & TEMA & $\begin{array}{c}\text { CONHECTMENTO } \\
\text { PREVTOS }\end{array}$ & $\begin{array}{c}\text { DURAC } \\
\text { no }\end{array}$ & Avo \\
\hline 1 & $\begin{array}{l}\text { Musica - } \\
\text { Caato coletrivo } \\
\text { na Africa do } \\
\text { Sul (anla 02) } \\
\text { Tehoteholósa } \\
\text { ", um canto de } \\
\text { trabalho }\end{array}$ & \begin{tabular}{|l|} 
Danael Fuls \\
Puag Cosutor: \\
Chada \\
Helena \\
Azeredo \\
Alvarenga \\
\end{tabular} & $\begin{array}{l}\text { Col de Aplic da } \\
\text { Uaiv Fed do Rio } \\
\text { de Jaseiro RJ }\end{array} \mid$ & $\begin{array}{l}\text { Ed Prof: } \\
\text { Ed Escolas } \\
\text { Indigens; } \\
\text { EM: EFF; } \\
\text { EJA 20: } \\
\text { ciclo: }\end{array}$ & $\begin{array}{l}\text { Artes, } \\
\text { Prodaçāo } \\
\text { Cultural e } \\
\text { Designr. }\end{array}$ & 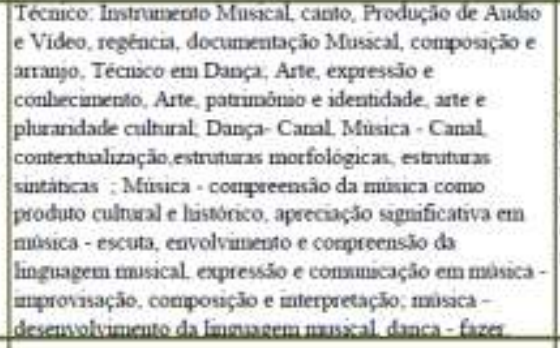 & $\begin{array}{l}\text { Noxóes de pulsaç̃oe } \\
\text { compasso, bem como } \\
\text { canto coletno a mais de } \\
\text { urma voz. } \\
\text { Opcionalmente, leitura } \\
\text { da grafia nassical } \\
\text { tradicional }\end{array}$ & $\begin{array}{l}2 \text { andas de } \\
50 \\
\text { minutos } \\
\text { (1h40 } \\
\text { min) }\end{array}$ & 2010 \\
\hline 2 & Musica para ge & $\begin{array}{l}\text { Julama Gomes } \\
\text { de Sotza Dias } \\
\text { Coautor: } \\
\text { Eziquiel } \\
\text { Menta } \\
\end{array}$ & $\begin{array}{l}\text { Secreraria } \\
\text { Estadual de } \\
\text { Educaça- } \\
\text { Cuaitiba PR }\end{array}$ & EM & Antes & Músicx Contextualizaclo & $\begin{array}{l}\text { Conbecimeato de } \\
\text { matemática: fracles e } \\
\text { proporscides. }\end{array}$ & $\begin{array}{l}04 \text { anlas } \\
\text { de } 50 \\
\text { minutos } \\
\text { cada }\end{array}$ & 2012 \\
\hline 3 & \begin{tabular}{|l} 
MúsicA - \\
Percussto \\
corporal Mios
\end{tabular} & $\begin{array}{l}\text { Rodingo } \\
\text { Russamo } \\
\text { Coautor: } \\
\text { Clatufa } \\
\text { Heleara } \\
\text { Azevedo } \\
\text { Alvarenga } \\
\end{array}$ & \begin{tabular}{|l|} 
Escola \\
Murucipal \\
Alencastro \\
Grimaraes - Rio \\
de Janeiro RJ \\
\end{tabular} & $\begin{array}{l}\text { EM: EJA } \\
1^{\circ} \text { ciclo; } \\
\text { EJA } 2^{*} \\
\text { ciclo; EFF }\end{array}$ & Artes & 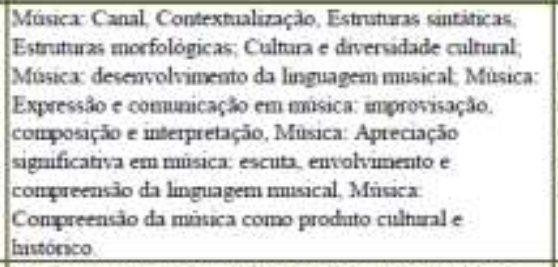 & $\begin{array}{l}\text { O traballho de jercussato } \\
\text { corporal pode ser feito } \\
\text { sem conhecimentos } \\
\text { formuis prévios em } \\
\text { Mrisica }\end{array}$ & $\begin{array}{l}1 \text { anla de } \\
50 \\
\text { minutos }\end{array}$ & 2010 \\
\hline 4 & $\begin{array}{l}\text { MUSICA - } \\
\text { escrita e leitura } \\
\text { musical: } \\
\text { compasse } \\
\text { (aula 2) } \\
\end{array}$ & $\begin{array}{l}\text { Countor } \\
\text { Cluadia } \\
\text { Helena } \\
\text { Azeredo } \\
\text { Alvarenga }\end{array}$ & \begin{tabular}{|l|} 
Escola \\
Municipal \\
Aleacastro \\
Gaimarses - Rio \\
de Janeivo RU \\
\end{tabular} & EM: EFF & Artes & 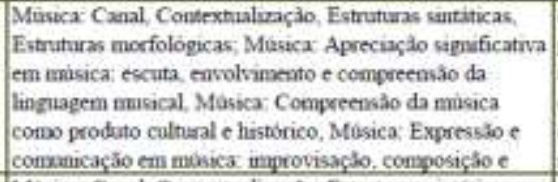 & $\begin{array}{l}\text { exenglos anusicais, o } \\
\text { professor devera ter feito } \\
\text { una pequena reflexclo } \\
\text { con a turna a sespento } \\
\text { do que considerar } \\
\text { relevante para a escrita }\end{array}$ & $\begin{array}{l}50 \\
\text { minustos }\end{array}$ & 2009 \\
\hline 5 & A ponte & $\begin{array}{l}\text { Juliaua } \\
\text { Gomes de } \\
\text { Souza Dias } \\
\text { Coauter: } \\
\text { Eriquiel } \\
\text { Menta }\end{array}$ & $\begin{array}{l}\text { Secieraria } \\
\text { Estadual de } \\
\text { Educacia - } \\
\text { Cuntaba PR }\end{array}$ & EM. EFF & Artes: Histó & $\begin{array}{l}\text { Mosica Canal, Consexnalinaçio, Estrutusas suntinicas, } \\
\text { Estruturas monfologicas, Memona, Poder, Cídadania e } \\
\text { cultura no mando. }\end{array}$ & 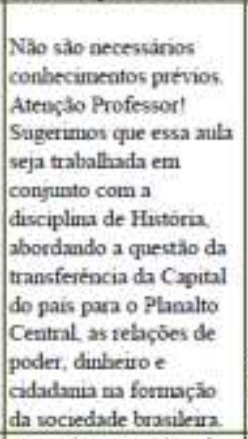 & $\begin{array}{l}02 \text { de } 50 \\
\text { munstos } \\
\text { cada }\end{array}$ & 2009 \\
\hline 6 & $\begin{array}{l}\text { MUSiCA - } \\
\text { Percussto } \\
\text { corponal: } \\
\text { Composigito } \\
\text { (aula 1) }\end{array}$ & $\begin{array}{l}\text { Rusiano } \\
\text { Coantor: } \\
\text { Clandia } \\
\text { Helena } \\
\text { Azevedo } \\
\text { Alvarenga }\end{array}$ & \begin{tabular}{|l|} 
Ercola \\
Municipal \\
Alencastro \\
Griesarses - Rio \\
de Janeiro RU \\
\end{tabular} & $\begin{array}{l}\text { EM: EFF; } \\
\text { EJA } 2^{\circ} \\
\text { cirlo }\end{array}$ & Artes & 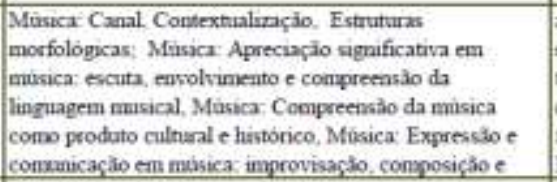 & $\begin{array}{l}\text { aproveitamento da aula, } \\
\text { inecessirno que um } \\
\text { trabalho de percusclo } \\
\text { corporal ja tenla sido } \\
\text { feito anteriormente. } \\
\text { Preferencialmeate, essa }\end{array}$ & $\begin{array}{l}1 \text { anla de } \\
50 \\
\text { minustos }\end{array}$ & 2010 \\
\hline 7 & $\begin{array}{l}\text { Urma orquestra } \\
\text { difereate }\end{array}$ & $\begin{array}{l}\text { Juliana Gonses } \\
\text { de Souza Dias } \\
\text { Couutor: } \\
\text { Eriquiel } \\
\text { Menta. }\end{array}$ & $\begin{array}{l}\text { Secreraria } \\
\text { Estadual de } \\
\text { Educaçăo- } \\
\text { Curitioa PR }\end{array}$ & & & 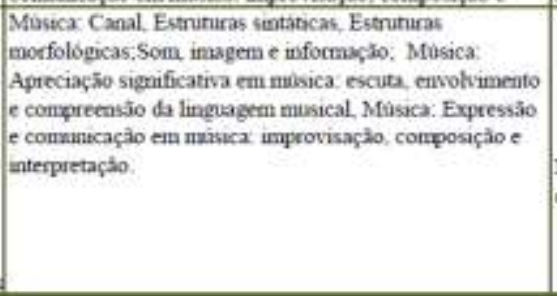 & $\begin{array}{l}\text { Nhäo sâo necessitios } \\
\text { conbecmestos prévios. }\end{array}$ & $\begin{array}{l}1 \text { a } 2 \\
\text { aulas de } \\
50 \\
\text { minunos } \\
\text { cada. } \\
\text { dependen } \\
\text { do do } \\
\text { tendiment } \\
\text { o dos } \\
\text { alunos }\end{array}$ & \\
\hline
\end{tabular}




\begin{tabular}{|c|c|c|c|c|c|c|c|c|c|}
\hline 8 & $\begin{array}{l}\text { MUSiCA - } \\
\text { escrita e leitura } \\
\text { musical: } \\
\text { donino com } \\
\text { figuras } \\
\text { musicais (anla } \\
\text { 3) }\end{array}$ & $\begin{array}{l}\text { Rodrigo } \\
\text { Rrussamo } \\
\text { Coautor: } \\
\text { Claudia } \\
\text { Helema } \\
\text { Azrvedo } \\
\text { Akrreaga } \\
\end{array}$ & \begin{tabular}{|l|} 
Escola \\
Mumicipal \\
Alencastro \\
Grumaraes - Rio \\
de Janeuro RJ \\
\end{tabular} & EM: EFE & Artes & 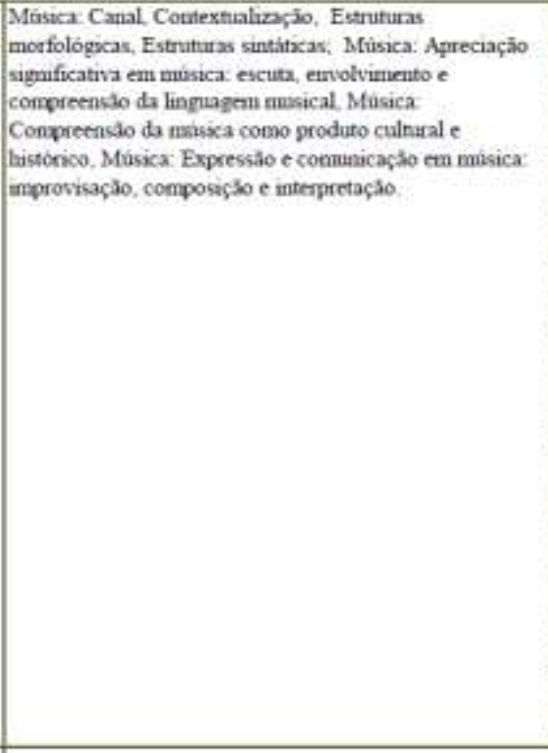 & 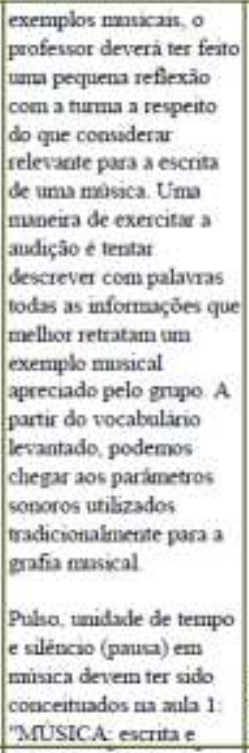 & \begin{tabular}{|l}
1 aula de \\
50 \\
mamutos
\end{tabular} & 2009 \\
\hline 9 & $\begin{array}{l}\text { MUSICA: } \\
\text { Construçào de } \\
\text { mustrumento } \\
\text { umsical - } \\
\text { violis de caixa } \\
\text { de sapato }\end{array}$ & $\begin{array}{l}\text { Rodrigo } \\
\text { Russano } \\
\text { Coantor } \\
\text { Claudia } \\
\text { Helena } \\
\text { Azevedo } \\
\text { Alvarenga }\end{array}$ & \begin{tabular}{|l|} 
Escola \\
Musacipal \\
Alencastro \\
Gsimusaes - Rio \\
de Janeiro RJ \\
\end{tabular} & $\begin{array}{l}\text { EM: EFF: } \\
\text { EJA } 1^{\circ} \\
\text { ciclo; EJA } \\
2^{\circ} \text { ciclo } \\
\end{array}$ & $\begin{array}{l}\text { Antes: } \\
\text { Estudo da } \\
\text { Sociedade } \\
\text { eda } \\
\text { Natureza: } \\
\text { Ciencias } \\
\text { Nanurais. } \\
\end{array}$ & 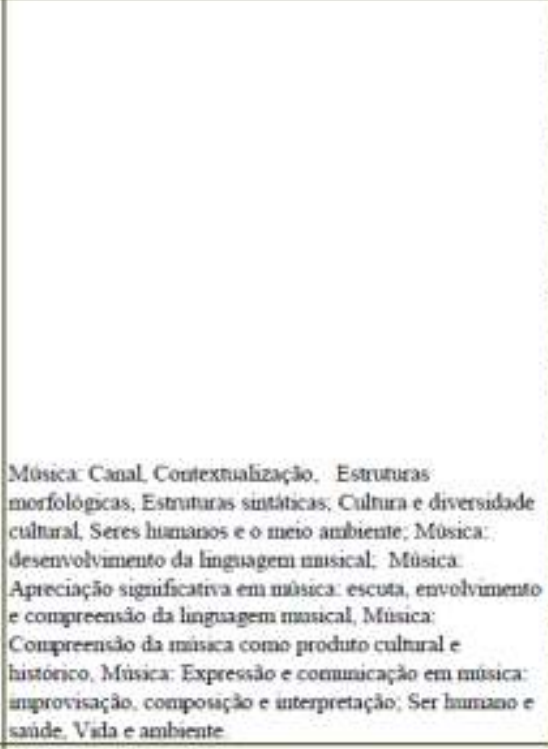 & 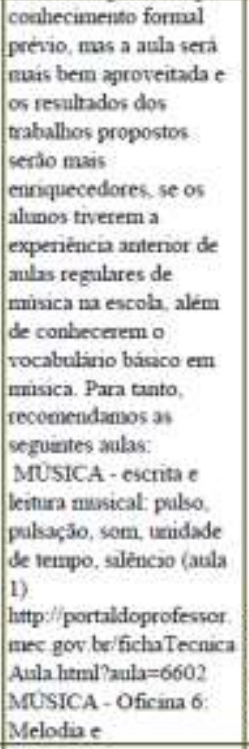 & $\begin{array}{l}2 \text { aulas de } \\
50 \\
\text { mamutos } \\
\text { (1h40mia } \\
\text { 2 }\end{array}$ & 2010 \\
\hline 10 & $\begin{array}{l}\text { Tropicala. } \\
\text { emisica. } \\
\text { comportament } \\
\text { o e atitude no } \\
\text { Brasil da } \\
\text { decada de } \\
1960 \\
\end{array}$ & $\begin{array}{l}\text { Bruno } \\
\text { Vweiros } \\
\text { Martias } \\
\text { Coautor } \\
\text { Ligia } \\
\text { Germaso } \\
\end{array}$ & $\begin{array}{l}\text { Universidade } \\
\text { Federal de } \\
\text { Minas Gernis, } \\
\text { Belo Horizonte } \\
\text { MG }\end{array}$ & EM:EIA 25 & $\begin{array}{l}\text { Antes: } \\
\text { Historia: } \\
\text { Lingua } \\
\text { Portaguesa } \\
\end{array}$ & 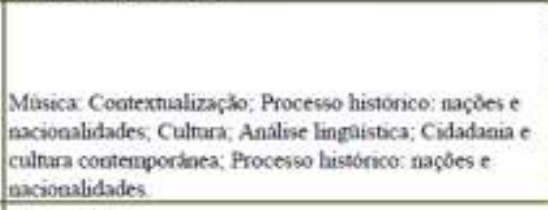 & $\begin{array}{l}\text { Morimento modernista } \\
\text { de } 1922 \\
\text { Golpe Civico-Militar de } \\
1904 \\
\text { Ato Instincional N' } 5 \text { de } \\
1908 \\
\text { Maio de } 1908 \\
\end{array}$ & $\begin{array}{l}\text { Tres asulas } \\
\text { de } 50 \\
\text { menutos. }\end{array}$ & \\
\hline 11 & $\begin{array}{l}\text { MUSICA - } \\
\text { Percussato } \\
\text { comporal Bocr }\end{array}$ & $\begin{array}{l}\text { Rodrigo } \\
\text { Russamo } \\
\text { Coautor: } \\
\text { Claudia } \\
\text { Helena } \\
\text { Azevedo } \\
\text { Alvareaga }\end{array}$ & \begin{tabular}{|l} 
Escola \\
Mumicipal \\
Alencastro \\
Guimaraes - Rio \\
de Janeiro RU
\end{tabular} & $\begin{array}{l}\text { EM; EFF; } \\
\text { EJA } 1^{\circ} \\
\text { ciclo; EJA } \\
2^{\circ} \text { ciclo }\end{array}$ & $\begin{array}{l}\text { Artes: } \\
\text { Estudo da } \\
\text { Sociedade } \\
\text { e da } \\
\text { Nanareza }\end{array}$ & 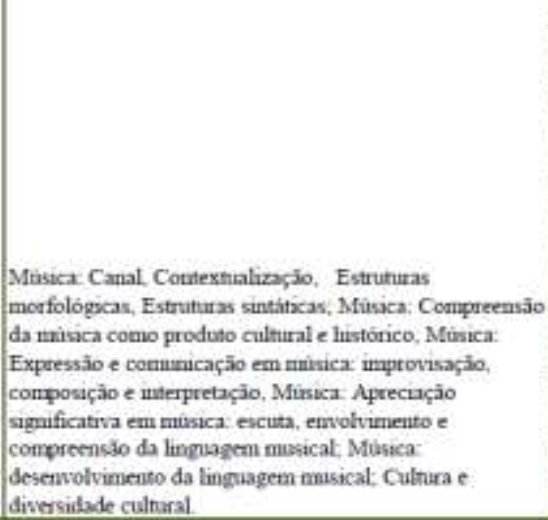 & 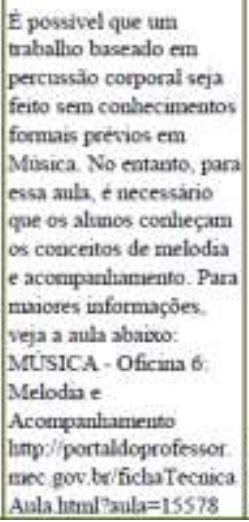 & $\begin{array}{l}1 \text { aula de } \\
50 \\
\text { mimutos }\end{array}$ & 2010 \\
\hline
\end{tabular}




\begin{tabular}{|c|c|c|c|c|c|c|c|c|c|}
\hline 12. & $\begin{array}{l}\text { Massica-Jogos } \\
\text { musicaia com } \\
\text { percassibo } \\
\text { corporal } \\
\text { percepsảo de } \\
\text { ntmo-anla } 4 \\
\end{array}$ & \begin{tabular}{|l|} 
Debora \\
Ferreina \\
Santos Broga: \\
Katia Regina \\
Figneriedo \\
Rounalo \\
Coautor: \\
Rodrigo \\
Russano
\end{tabular} & $\begin{array}{l}\text { Colegio de } \\
\text { Aplicacalo da } \\
\text { Universidade } \\
\text { Federal do Rio } \\
\text { de Janeiro - } \\
\text { Equipe } \\
\text { CApUFR } \\
\end{array}$ & $\begin{array}{l}\text { EM: EFF, } \\
\text { EFL: EJA } \\
2^{\circ} \text { ciclo } \\
\end{array}$ & Antes & 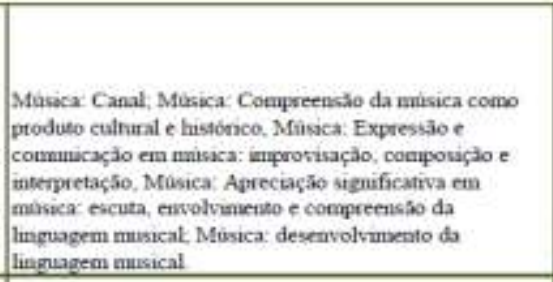 & $\begin{array}{l}\text { Astociaça do estimulo } \\
\text { sonoro so movimento } \\
\text { conporal - Lvire ou nlo }\end{array}$ & $\begin{array}{l}\text { Una aula } \\
\text { de } 50 \\
\text { minutios }\end{array}$ & 2010 \\
\hline 13 & $\begin{array}{l}\text { O Fund } \\
\text { carioca e sta } \\
\text { dimienica } \\
\text { social }\end{array}$ & $\begin{array}{l}\text { Raboel da } \\
\text { Cruz Alves. } \\
\text { Coantor: } \\
\text { Ligia Beatriz } \\
\text { de Patula } \\
\text { Germano } \\
\end{array}$ & $\begin{array}{l}\text { Uaiversidade } \\
\text { Federal de } \\
\text { Minas Gerass, } \\
\text { Belo Horizonte } \\
\text { MG }\end{array}$ & $\begin{array}{l}\text { EM: EJA } \\
2^{\circ} \text { ciclo }\end{array}$ & $\begin{array}{l}\text { Autes; } \\
\text { Históna; } \\
\text { Sociologia }\end{array}$ & 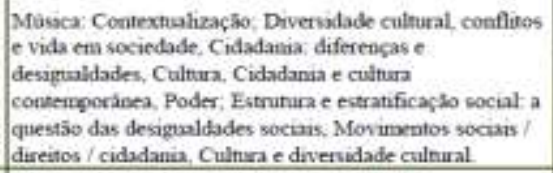 & 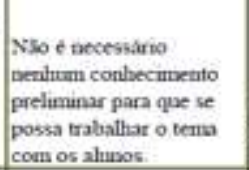 & \begin{tabular}{|l|} 
Trés anlas \\
de 50 \\
minutos
\end{tabular} & 2011 \\
\hline 14 & \begin{tabular}{|l|} 
Mursaca - \\
Trilla sonora \\
Projeto e \\
Roteiro
\end{tabular} & $\begin{array}{l}\text { Leonardo } \\
\text { Stefano } \\
\text { Masqua } \\
\text { Coautor: } \\
\text { Rodrigo } \\
\text { Russano }\end{array}$ & $\begin{array}{l}\text { Col de Aplic da } \\
\text { Uriv Fed do Rio } \\
\text { de Janeiro. RJ }\end{array}$ & EM-EFF & Artes & 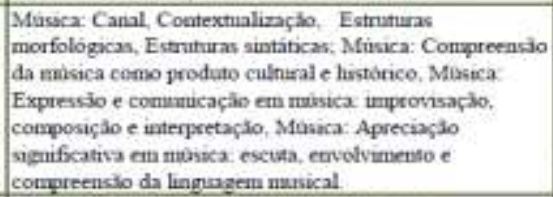 & $\begin{array}{l}\text { Conthecimento nussicas } \\
\text { abo-formal. }\end{array}$ & $\begin{array}{l}i \text { aula de } \\
50 \\
\text { minutos }\end{array}$ & 2011 \\
\hline 15 & $\begin{array}{l}\text { MUSICA- } \\
\text { Oficina 3: } \\
\text { parsagem } \\
\text { wonora. }\end{array}$ & $\begin{array}{l}\text { Rodngo } \\
\text { Russano } \\
\text { Coautor: } \\
\text { Claudia } \\
\text { Helesa } \\
\text { Azrevedo } \\
\text { Ahrarenga }\end{array}$ & $\begin{array}{l}\text { Eucola } \\
\text { Municipal } \\
\text { Adencastro } \\
\text { Guamarses - Rio } \\
\text { de Janeiro fU }\end{array}$ & EM: EFF & Antes & 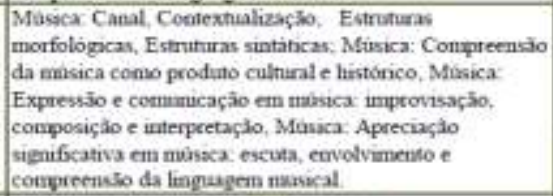 & $\begin{array}{l}\text { Parainetros do som. } \\
\text { conlvecimento uầ } \\
\text { formal sobte musica em } \\
\text { peral }\end{array}$ & $\begin{array}{l}50 \\
\text { munintes }\end{array}$ & 2009 \\
\hline 16 & \begin{tabular}{|l|} 
MÚ́SICA - \\
Oficina 4 - O \\
marverso do DJ
\end{tabular} & $\begin{array}{l}\text { Rodrigo } \\
\text { Russano } \\
\text { Coautor: } \\
\text { Claudea } \\
\text { Helena } \\
\text { Azevedo } \\
\text { Alwerenga } \\
\end{array}$ & \begin{tabular}{|l|} 
Escola \\
Mlumicipal \\
Alencastro \\
Guimuraes, Rio \\
de Ianieiso RJ \\
\end{tabular} & EM EFF & Antes & 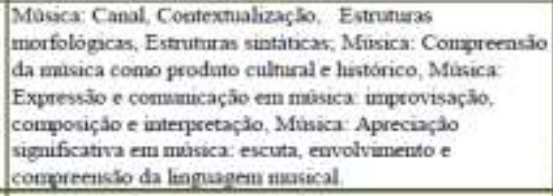 & $\begin{array}{l}\text { Conluecimenton muricais } \\
\text { olo formais }\end{array}$ & $\begin{array}{l}50 \\
\text { trinutes }\end{array}$ & 2009 \\
\hline 17 & $\begin{array}{l}\text { MúsicA - } \\
\text { Percussido } \\
\text { corporat } \\
\text { Composiçàio } \\
\text { (anla 2) }\end{array}$ & $\begin{array}{l}\text { Rodngo } \\
\text { Russano } \\
\text { Coautor: } \\
\text { Claudia } \\
\text { Heienas } \\
\text { Azrvedo } \\
\text { Alvarenga } \\
\end{array}$ & \begin{tabular}{|l|} 
Escola \\
Mumicipal \\
Alencastro \\
Guimurses - Rio \\
de Jatieiro fN \\
\end{tabular} & $\begin{array}{l}\text { EM, EFI: } \\
\text { EJA } 1^{\circ} \\
\text { ciclo; EJA } \\
2^{\circ} \text { ciclo } \\
\end{array}$ & $\begin{array}{l}\text { Artes: } \\
\text { Estudo da } \\
\text { Sociedade } \\
\text { eda } \\
\text { Nanareza } \\
\end{array}$ & 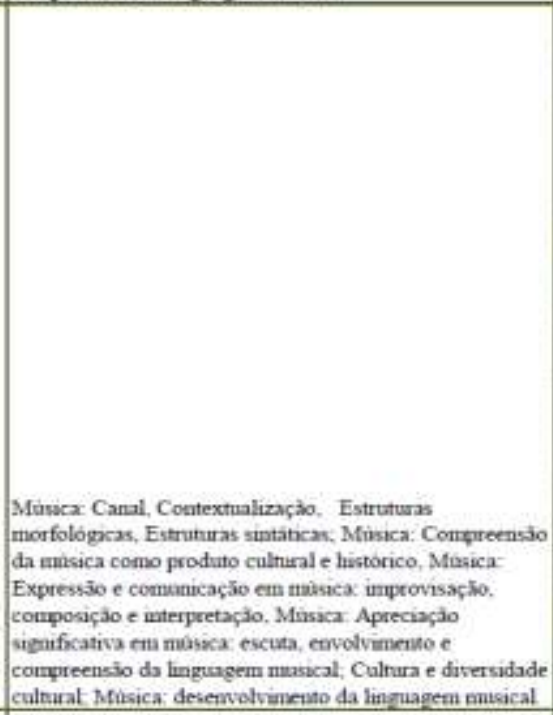 & 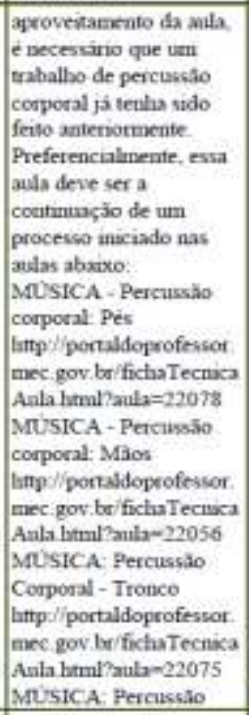 & $\begin{array}{l}1 \text { aula de } \\
50 \\
\text { minustos }\end{array}$ & 2010 \\
\hline 18 & $\begin{array}{l}\text { Música - } \\
\text { Grimboot } \\
\text { Duncing. } \\
\text { dança de } \\
\text { resistencia das } \\
\text { minas da } \\
\text { Africa do Sul } \\
\text { - aula 01 } \\
\end{array}$ & $\begin{array}{l}\text { Datael Fuls } \\
\text { Puig Coanutor: } \\
\text { Claudia } \\
\text { Heleasa } \\
\text { Azrevedo } \\
\text { Alvarenga }\end{array}$ & $\begin{array}{l}\text { Col de Aplic do } \\
\text { Ulinis Fed do Rio } \\
\text { de Janeiro. RJ }\end{array}$ & $\begin{array}{l}\text { EM: EFF: } \\
\text { EJA 10 } \\
\text { ciclo: EJA } \\
2^{\circ} \text { ciclo: } \\
\text { Educapalo } \\
\text { Escolar } \\
\text { Endigens }\end{array}$ & $\begin{array}{l}\text { Artes; } \\
\text { Estudo da } \\
\text { Sociedade } \\
\text { e da } \\
\text { Nahuega } \\
\end{array}$ & 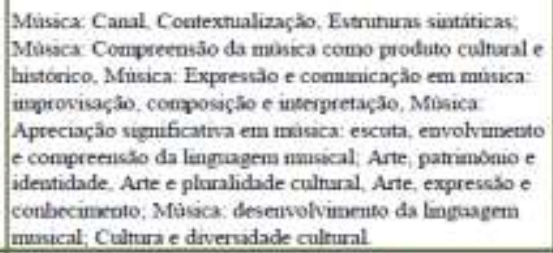 & 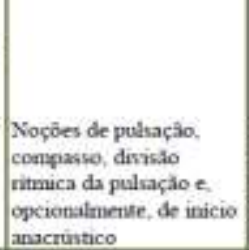 & $\begin{array}{l}2 \text { anlav de } \\
\text { 50 } \\
\text { minutos } \\
\text { (1b+o } \\
\text { min) }\end{array}$ & 2009 \\
\hline 19 & $\begin{array}{l}\text { Musica - } \\
\text { crias lo de } \\
\text { cansilo: ritmo } \\
\text { e gtaero }\end{array}$ & $\begin{array}{l}\text { Leouardo } \\
\text { Stefano } \\
\text { Masquio } \\
\text { Coastor: } \\
\text { Claudia } \\
\text { Helena } \\
\text { Azrtedo } \\
\text { Alvarenga }\end{array}$ & $\begin{array}{l}\text { Col de Aplic da } \\
\text { Univ Fed do Rio } \\
\text { de Javieito. RJ. }\end{array}$ & $\begin{array}{l}\text { EM: EFF: } \\
\text { EJA } 10 \\
\text { aclo: EJA } \\
2^{\circ} \text { ciclo }\end{array}$ & $\begin{array}{l}\text { Artes: } \\
\text { Estrudo da } \\
\text { Sociedade } \\
\text { eda } \\
\text { Nanareza }\end{array}$ & 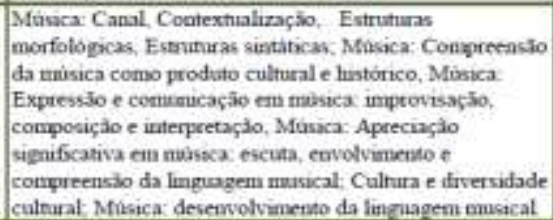 & $\begin{array}{l}\text { Conhecimento nusical } \\
\text { enformal }\end{array}$ & $\begin{array}{l}1 \text { anla de } \\
50 \\
\text { minutes }\end{array}$ & \\
\hline
\end{tabular}




\begin{tabular}{|c|c|c|c|c|c|c|c|c|c|}
\hline 20 & $\begin{array}{l}\text { MUUSICA: } \\
\text { Elementos de } \\
\text { expressio } \\
\text { (andanneato) - } \\
\text { accelerando e } \\
\text { ralleatando }\end{array}$ & $\begin{array}{l}\text { Rodago } \\
\text { Russano } \\
\text { Coautor. } \\
\text { Claudia } \\
\text { Heiena } \\
\text { Azevedo } \\
\text { Alwsienga } \\
\end{array}$ & \begin{tabular}{|l|} 
Escola \\
Municipal \\
Alencastro \\
Guinaraes - Rao \\
de Janeio RJ \\
\end{tabular} & $\begin{array}{l}\text { EM: EFF: } \\
\text { EA } 2^{\circ} \\
\text { ciclo }\end{array}$ & Artes & 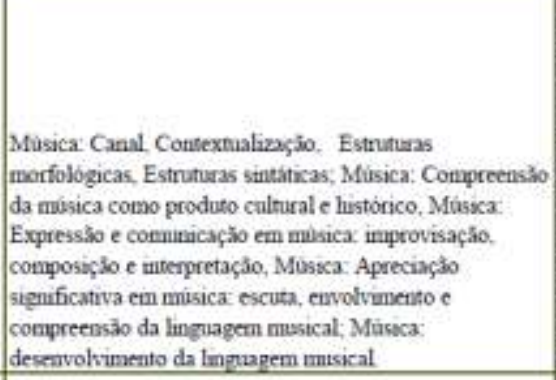 & 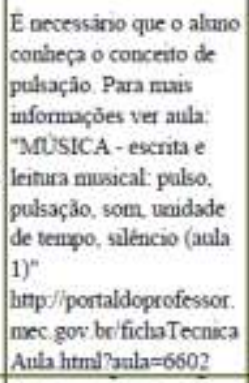 & $\begin{array}{l}1 \text { aula de } \\
50 \\
\text { minnitos }\end{array}$ & 2010 \\
\hline 21 & $\begin{array}{l}\text { MúSICA: } \\
\text { Composicào- } \\
\text { Frase }\end{array}$ & \begin{tabular}{|l} 
Rodoigo \\
Russano \\
Coautor: \\
Claudta \\
Helena \\
Azevedo \\
Alrarenga \\
\end{tabular} & \begin{tabular}{|l|} 
Escola \\
Muructpal \\
Alencastro \\
Guimaraes - Rio \\
de Janeito RJ \\
\end{tabular} & $\begin{array}{l}\text { EM; EFF: } \\
\text { EJA } 2^{\circ} \\
\text { iclo }\end{array}$ & Artes & 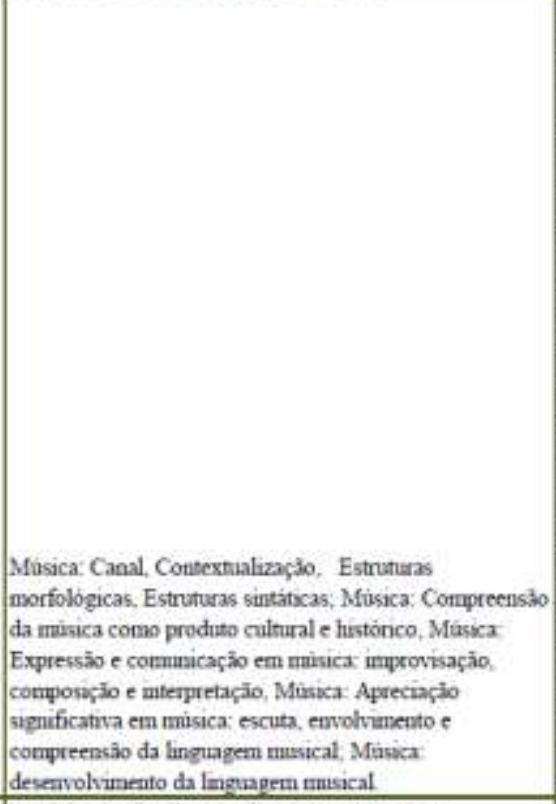 & 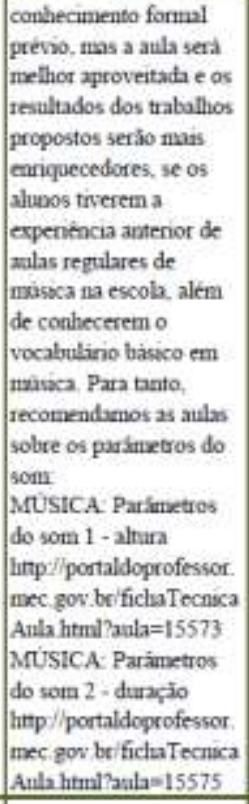 & $\begin{array}{l}1 \text { aula de } \\
50 \\
\text { minutos } \\
\end{array}$ & \\
\hline 22 & $\begin{array}{l}\text { Música - } \\
\text { Criação de } \\
\text { canção- } \\
\text { "Estudando o } \\
\text { camula" (parte } \\
\text { 2) }\end{array}$ & \begin{tabular}{|l} 
Leonardo \\
Stefano \\
Masquio \\
Coautor \\
Rodrigo \\
Russano \\
\end{tabular} & $\begin{array}{l}\text { Col de Aplic da } \\
\text { Uuiv Fed do Rio } \\
\text { de Janeiro. RU. }\end{array}$ & $\begin{array}{l}\text { EM; EFI: } \\
\text { EA 1= } \\
\text { cílo }\end{array}$ & $\begin{array}{l}\text { Artes: } \\
\text { Estudo da } \\
\text { Sociedade } \\
\text { eda } \\
\text { Natuea } \\
\end{array}$ & 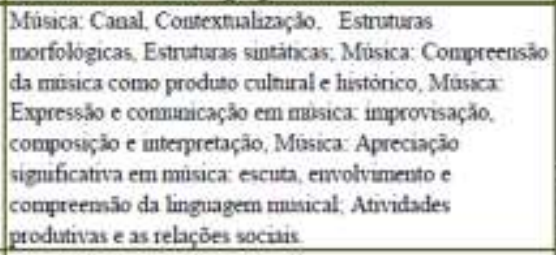 & $\begin{array}{l}\text { Conceito de melodia } \\
\text { Conceito de gènero } \\
\text { maxical }\end{array}$ & $\begin{array}{l}1 \text { anla de } \\
50 \\
\text { niminates }\end{array}$ & \\
\hline & $\begin{array}{l}\text { MúSICA: } \\
\text { Composição- } \\
\text { Elementos de } \\
\text { Contraste }\end{array}$ & $\begin{array}{l}\text { Rodrigo } \\
\text { Russano } \\
\text { Coautor: } \\
\text { Claudia } \\
\text { Helema } \\
\text { Azevedo } \\
\text { Alvarengas } \\
\end{array}$ & \begin{tabular}{|l|} 
Escola \\
Municipal \\
Alencastro \\
Guimaraes - Rio \\
de hoeiro RS \\
\end{tabular} & & Antes & 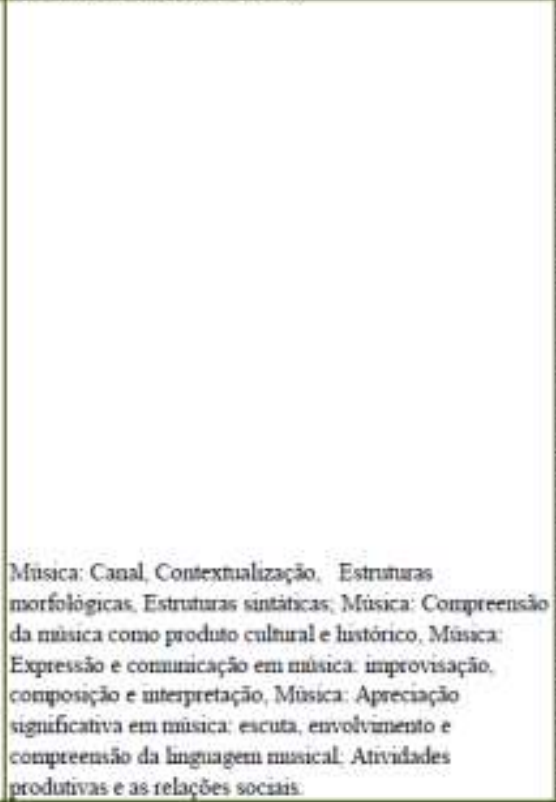 & 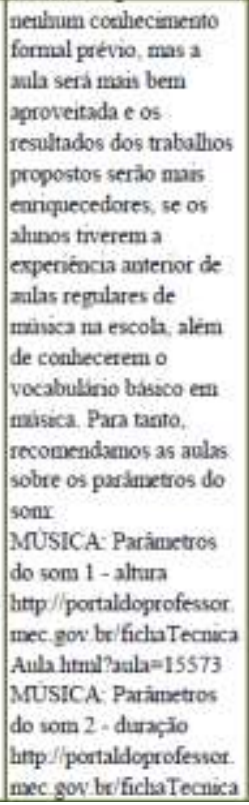 & $\begin{array}{l}1 \text { anta de } \\
\text { so } \\
\text { inimutos }\end{array}$ & \\
\hline
\end{tabular}




\begin{tabular}{|c|c|c|c|c|c|c|c|c|c|}
\hline 24 & $\begin{array}{l}\text { Musica - Pedal } \\
\text { c Ottinsto. } \\
\text { una } \\
\text { experièocia de } \\
\text { composiçäo } \\
\text { com alumos em } \\
\text { sala de aula. } \\
\text { atala } 02\end{array}$ & $\begin{array}{l}\text { Dariel Fils } \\
\text { Puing Coautor: } \\
\text { Clauda } \\
\text { Helena } \\
\text { Azevedo } \\
\text { Alvatenga }\end{array}$ & $\begin{array}{l}\text { Col de Aplic da } \\
\text { Unav Fed do Rio } \\
\text { de Janeiro. RU }\end{array}$ & $\begin{array}{l}\text { EM; EFF; } \\
\text { EJA 20 } \\
\text { ciclo }\end{array}$ & Artes & 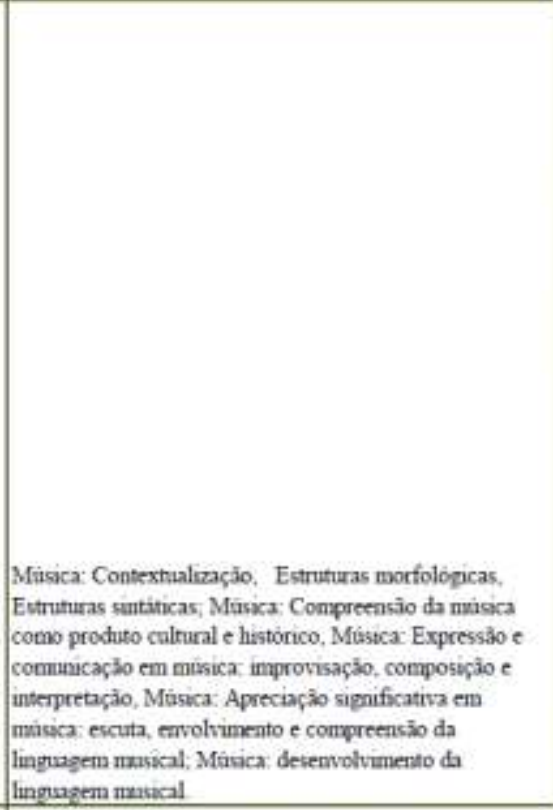 & 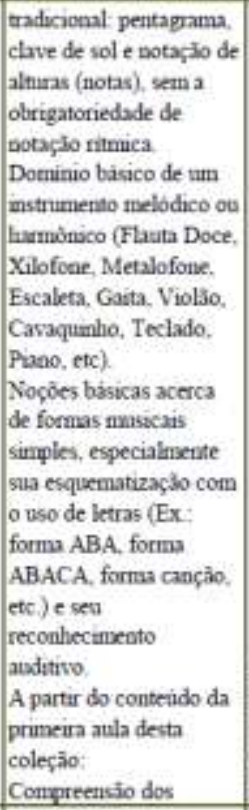 & $\begin{array}{l}2 \text { aulas de } \\
50 \\
\text { mimutos } \\
\text { (th40 } \\
\text { min) }\end{array}$ & 2009 \\
\hline 25 & $\begin{array}{l}\text { Musica - } \\
\text { criaça de } \\
\text { canclo: } \\
\text { concetto - mala } \\
1\end{array}$ & $\begin{array}{l}\text { Leonardo } \\
\text { Stefino } \\
\text { Masquado } \\
\text { Countor: } \\
\text { Clandea } \\
\text { Helena } \\
\text { Azevedo } \\
\text { Alvarenga }\end{array}$ & $\begin{array}{l}\text { Col de Aplac da } \\
\text { Univ Fed do Rio } \\
\text { de Janeiro. RJ. }\end{array}$ & $\begin{array}{l}\text { EM: EFF; } \\
\text { EJA } 1^{\circ} \\
\text { ciclo; EJA } \\
2^{\circ} \text { ciclo }\end{array}$ & $\begin{array}{l}\text { Artes; } \\
\text { Estudo da } \\
\text { Sociedade } \\
\text { e da } \\
\text { Nanareza }\end{array}$ & 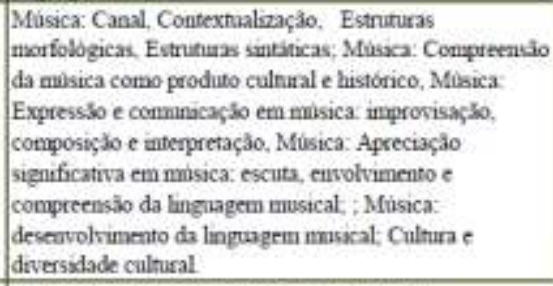 & $\begin{array}{l}\text { Conbecineato nusical } \\
\text { unformal }\end{array}$ & $\begin{array}{l}1 \text { aula de } \\
50 \\
\text { minntos }\end{array}$ & 2010 \\
\hline 26 & $\begin{array}{l}\text { Musica- } \\
\text { criacilo de } \\
\text { cans,io: } \\
\text { teloçbo entre } \\
\text { texto, melodia } \\
\text { e li }\end{array}$ & $\begin{array}{l}\text { Leonardo } \\
\text { Stefano } \\
\text { Masquio } \\
\text { Coardor: } \\
\text { Clatula } \\
\text { Helena } \\
\text { Azevedo } \\
\text { Alvarenga } \\
\end{array}$ & $\begin{array}{l}\text { Col de Aplic da } \\
\text { Univ Fed do Rio } \\
\text { de Janeiro. RU. }\end{array}$ & $\begin{array}{l}\text { EM, EFF; } \\
\text { EIA } 1^{\circ} \\
\text { ciclo; EJA } \\
2^{\circ} \text { ciclo }\end{array}$ & $\begin{array}{l}\text { Artes; } \\
\text { Estudo da } \\
\text { Sociedade } \\
\text { eda } \\
\text { Natareza; } \\
\text { Citncias } \\
\text { Nanurats: } \\
\text { Estudo da } \\
\text { Sociedade } \\
\text { eda } \\
\text { Natureza. }\end{array}$ & 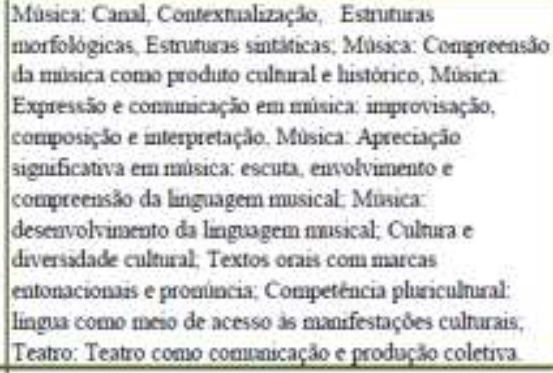 & $\begin{array}{l}\text { Conbecimeato musical } \\
\text { informal }\end{array}$ & $\begin{array}{l}1 \text { aula de } \\
50 \\
\text { minutos }\end{array}$ & 2010 \\
\hline 27 & O Tom do Sam & $\begin{array}{l}\text { Julana Gomes } \\
\text { de Souza Dias } \\
\text { Coautor } \\
\text { Exquaiel } \\
\text { Menta }\end{array}$ & $\begin{array}{l}\text { Secrerara } \\
\text { Eatadral de } \\
\text { Educaçio - } \\
\text { Curitiba PR }\end{array}$ & EM & ites & $\begin{array}{l}\text { Missica: Camal, Contextualizaçào, Estruturas } \\
\text { morfológicas Estruturas suntiticas. }\end{array}$ & $\begin{array}{l}\text { O contexto histórico, } \\
\text { politico e social do pais } \\
\text { ma década de } 1950 \text {, } \\
\text { acontecimetitos mais } \\
\text { muportantes }\end{array}$ & $\begin{array}{l}4 \text { a } 5 \\
\text { anlas de } \\
50 \\
\text { minutos } \\
\text { cada }\end{array}$ & 2009 \\
\hline 28 & $\begin{array}{l}\text { Dança de } \\
\text { Sallio: } \\
\text { Introdus,jo ao } \\
\text { Forró }\end{array}$ & \begin{tabular}{|l|} 
Frederico \\
Marcelo \\
Crocbet \\
Coautor \\
Nelson Vieira \\
da Fonseca \\
Faria
\end{tabular} & $\begin{array}{l}\text { Col de Aplic } \\
\text { Joso XXIII - } \\
\text { Jusz de Fora - } \\
\text { MG }\end{array}$ & EM & Artes: & $\begin{array}{l}\text { Musica: Canal, Contexnualizaçajo; Dança: Estruturas } \\
\text { morfolópicas, Canal Contextualizaçlo. }\end{array}$ & $\begin{array}{l}\text { N3ho é necessánio } \\
\text { conhecinsento previo }\end{array}$ & $\begin{array}{l}4 \text { aulas de } \\
50 \\
\text { minutos }\end{array}$ & 2011 \\
\hline 29 & $\begin{array}{l}\text { Masaca - } \\
\text { Matennasicas - } \\
\text { Tempo }\end{array}$ & $\begin{array}{l}\text { Luciano Cintra } \\
\text { Silveira }\end{array}$ & $\begin{array}{l}\text { Col de Aplic da } \\
\text { Univ Fed do Rio } \\
\text { de Janeiro. RJ }\end{array}$ & $\begin{array}{l}\text { EM, EFF; } \\
\text { EJA 2a } \\
\text { ciclo }\end{array}$ & & 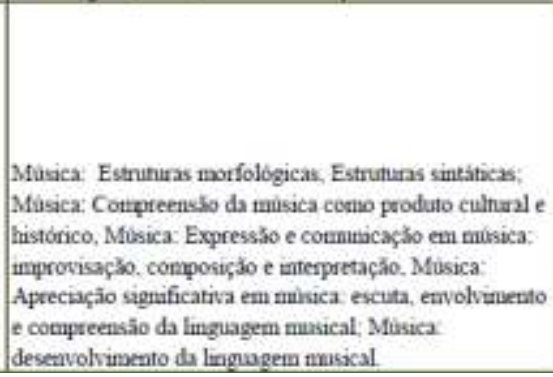 & 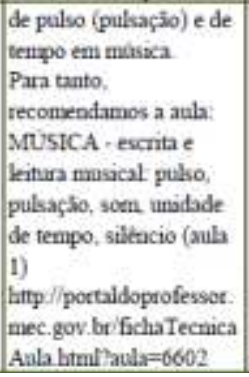 & $\begin{array}{l}1 \text { aula de } \\
50 \\
\text { mismtos }\end{array}$ & \\
\hline
\end{tabular}




\begin{tabular}{|c|c|c|c|c|c|c|c|c|c|}
\hline 30 & $\begin{array}{l}\text { Música - } \\
\text { Composição } \\
\text { Imagistica } \\
\text { (parte 1) }\end{array}$ & \begin{tabular}{|l|} 
Luciano Cintra \\
Silveira \\
Coautor. \\
Claudia \\
Helema \\
Azevedo \\
Alvareaga \\
\end{tabular} & $\begin{array}{l}\text { Col de Aplic da } \\
\text { Univ Fed do Rio } \\
\text { de Janeiro. RJ. }\end{array}$ & $\begin{array}{l}\text { EM; EFF; } \\
\text { EJA } 2^{\circ} \\
\text { ciclo }\end{array}$ & Artes & 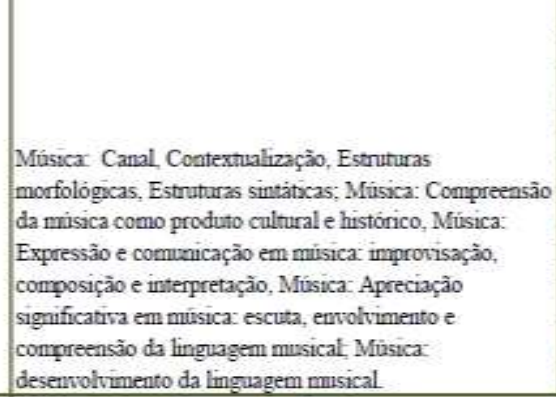 & $\begin{array}{l}\text { Os alunos devem } \\
\text { coahecer os parámetros } \\
\text { do som (intensidade, } \\
\text { duaração, altura e timbre) } \\
\text { e devem ser capazes de } \\
\text { manipular a fonte sonora } \\
\text { de forma expressiva. } \\
\text { Devem ser capazes de } \\
\text { vocalizar de forma } \\
\text { criativa e improvisatória, } \\
\text { de forma coerente com } \\
\text { as variacōes propostas. }\end{array}$ & $\begin{array}{l}1 \text { aula de } \\
50 \\
\text { minutos }\end{array}$ & 2010 \\
\hline 31 & $\begin{array}{l}\text { Música - } \\
\text { criação de } \\
\text { canção: tema e } \\
\text { forma }\end{array}$ & $\begin{array}{l}\text { Leonardo } \\
\text { Stefano } \\
\text { Masquio } \\
\text { Coautor: } \\
\text { Claudia } \\
\text { Helema } \\
\text { Azevedo } \\
\text { Alvarenga } \\
\end{array}$ & $\begin{array}{l}\text { Col de Aplic da } \\
\text { Univ Fed do Rio } \\
\text { de Janeiro. RJ. }\end{array}$ & $\begin{array}{l}\text { EM; EFF; } \\
\text { EJA } 1^{\circ} \\
\text { ciclo; EJA } \\
2^{\circ} \text { ciclo }\end{array}$ & \begin{tabular}{|l} 
Artes, \\
Estudo da \\
Sociedade \\
eda \\
Natureza
\end{tabular} & 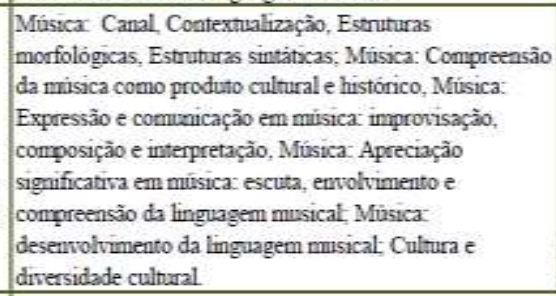 & $\begin{array}{l}\text { Conhecimento musical } \\
\text { informal }\end{array}$ & $\begin{array}{l}1 \text { aula de } \\
50 \\
\text { minutos }\end{array}$ & 2010 \\
\hline 32 & $\begin{array}{l}\text { Música - } \\
\text { Matemúsicas - } \\
\text { Matriz (parte 2 }\end{array}$ & \begin{tabular}{|l|} 
Luciano Cintra \\
Silveira \\
Coautor. \\
Claudia \\
Helena \\
Azevedo \\
Alvareaga \\
\end{tabular} & $\begin{array}{l}\text { Col de Aplic da } \\
\text { Univ Fed do Rio } \\
\text { de Janeiro. RJ. }\end{array}$ & $\begin{array}{l}\text { EM: EFF; } \\
\text { EJA } 2^{\circ} \\
\text { ciclo }\end{array}$ & Artes & 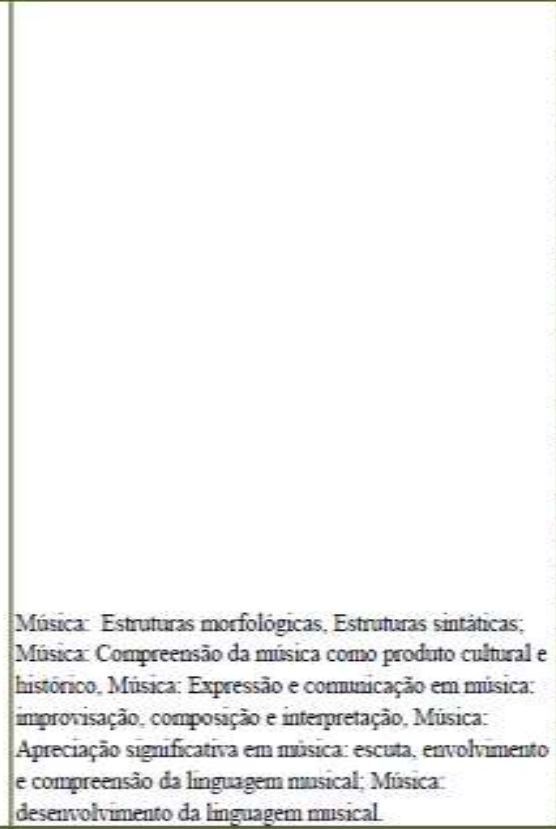 & 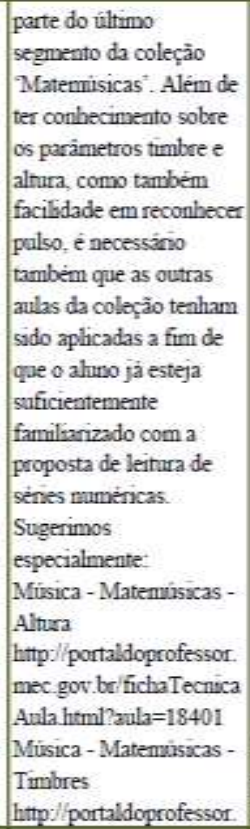 & $\begin{array}{l}1 \text { aula de } \\
50 \\
\text { minutos }\end{array}$ & 2010 \\
\hline 33 & $\begin{array}{l}\text { Música - } \\
\text { Matemúsicas - } \\
\text { Altura }\end{array}$ & $\begin{array}{l}\text { Luciano Cintra } \\
\text { Silveira } \\
\text { Coautor: } \\
\text { Claudia } \\
\text { Helena } \\
\text { Azevedo } \\
\text { Alvareaga } \\
\end{array}$ & $\begin{array}{l}\text { Col de Aplic da } \\
\text { Univ Fed do Rio } \\
\text { de Janeiro. RJ. }\end{array}$ & $\begin{array}{l}\text { EM; EFF; } \\
\text { EJA } 2^{\circ} \\
\text { ciclo }\end{array}$ & Artes & 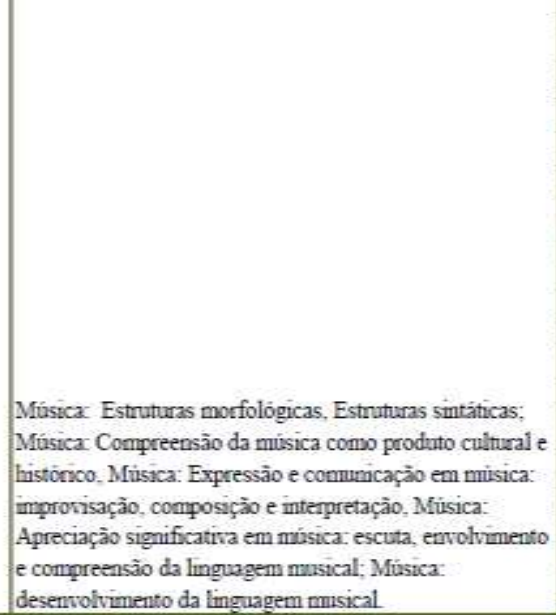 & 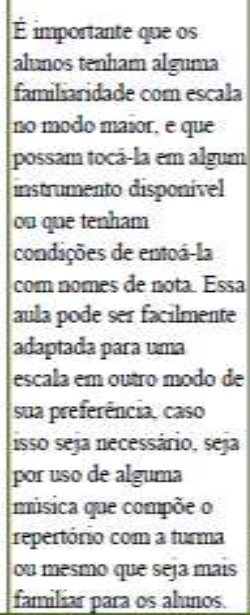 & $\begin{array}{l}1 \text { aula de } \\
50 \\
\text { minutos }\end{array}$ & 2010 \\
\hline
\end{tabular}




\begin{tabular}{|c|c|c|c|c|c|c|c|c|c|}
\hline 34 & $\begin{array}{l}\text { MUSICA: } \\
\text { Coniposiça - } \\
\text { Objeto Sonoro } \\
\text { e Muisica } \\
\text { Concreta }\end{array}$ & $\begin{array}{l}\text { Rodrigo } \\
\text { Russatwo } \\
\text { Coautor: } \\
\text { Claudia } \\
\text { Helena } \\
\text { Azevedo } \\
\text { Alvarenga }\end{array}$ & \begin{tabular}{|l|} 
Escola \\
Municipal \\
Alencastro \\
Guamaraes - Roo \\
de Janeiro RJ \\
\end{tabular} & $\begin{array}{l}\text { EM: EFF; } \\
\text { EJA ? } \\
\text { ciclo }\end{array}$ & Artes & 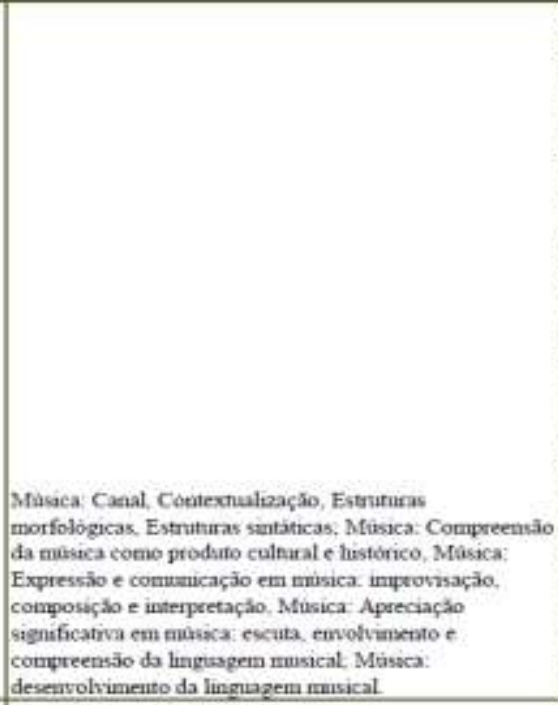 & 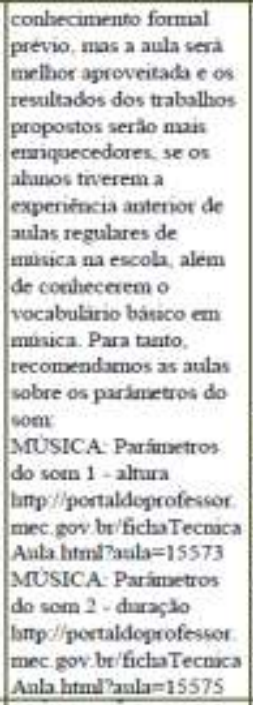 & $\begin{array}{l}1 \text { auba de } \\
50 \\
\text { minutos } \\
\text { ou } 2 \text { ablas } \\
\text { de } 50 \\
\text { minutos } \\
\text { (se } \\
\text { utilizar os } \\
\text { softwares } \\
\text { sigerndos } \\
\end{array}$ & 2010 \\
\hline 35 & 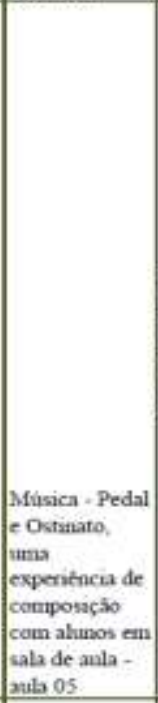 & $\begin{array}{l}\text { Datuel Fuls } \\
\text { Puag Coututor: } \\
\text { Claudia } \\
\text { Helma } \\
\text { Azesiedo } \\
\text { Alvarenga }\end{array}$ & $\begin{array}{l}\text { Col de Aplic da } \\
\text { Univ Fed do Rio } \\
\text { de Janeiro. RU. }\end{array}$ & $\begin{array}{l}\text { EM: EFF: } \\
\text { EIA } 20 \\
\text { Eiclo }\end{array}$ & Arles & 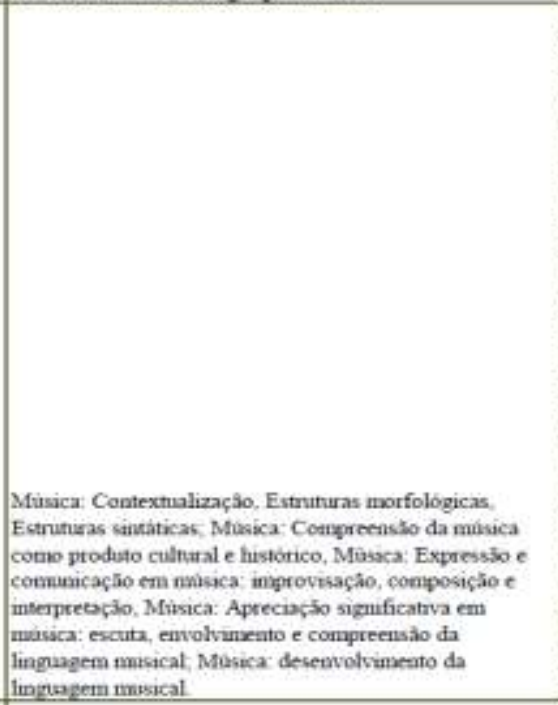 & 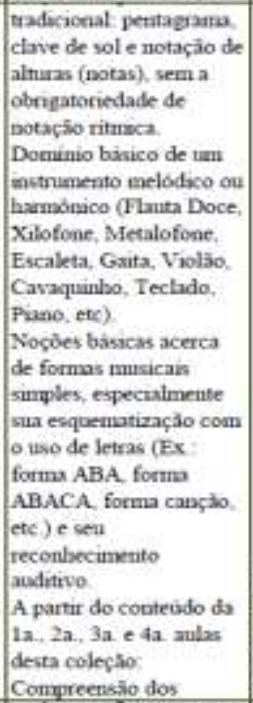 & $\begin{array}{l}2 \text { aulas de } \\
50 \\
\text { munutos } \\
\text { (th } 40 \mathrm{~min}\end{array}$ & 2010 \\
\hline 30 & 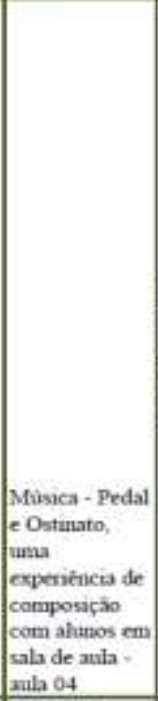 & $\begin{array}{l}\text { Dasuiel Fils } \\
\text { Puag Coautor: } \\
\text { Clatuda } \\
\text { Helena } \\
\text { Azrevedo } \\
\text { Alvarenga }\end{array}$ & $\begin{array}{l}\text { Col de Aplic da } \\
\text { Univ Fed do Rio } \\
\text { de Javerio RU }\end{array}$ & $\begin{array}{l}\text { EM: EFF: } \\
\text { EJA } 2^{\circ} \\
\text { ciclo }\end{array}$ & Antes & 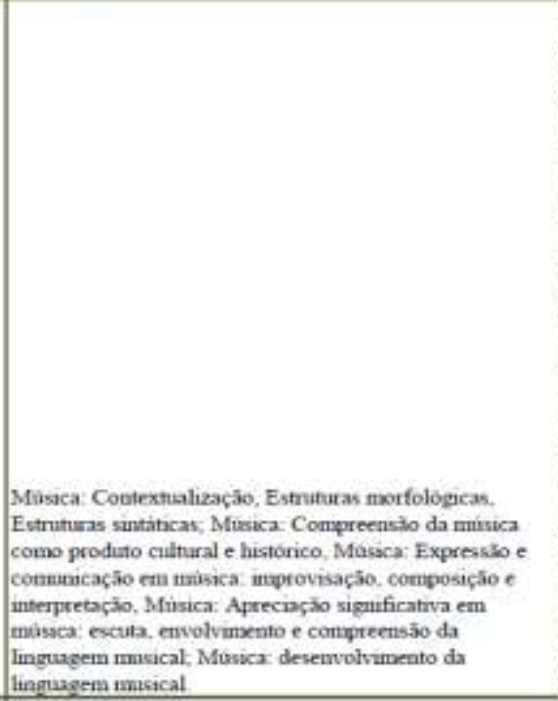 & 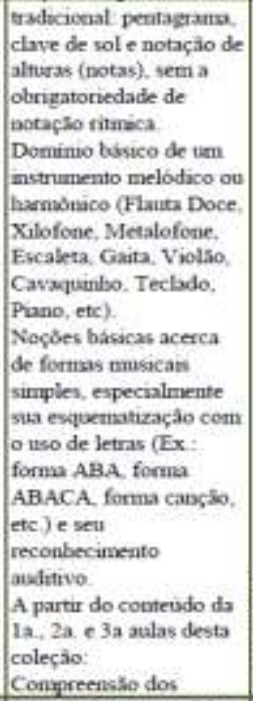 & $\begin{array}{l}2 \text { aulss de } \\
50 \\
\text { mimitos } \\
\text { (th40min }\end{array}$ & 2009 \\
\hline 37 & \begin{tabular}{|l|} 
Recepcio, \\
gosto e \\
identidade - \\
segrinds paste \\
Gauh 5
\end{tabular} & $\begin{array}{l}\text { Silvema } \\
\text { Coanutor } \\
\text { Claudua } \\
\text { Helena } \\
\text { Azevedo }\end{array}$ & $\begin{array}{l}\text { Col de Aplic da } \\
\text { Univ Fed do Rio } \\
\text { de Janeiro. RU. }\end{array}$ & $\begin{array}{l}\text { EM: EIA } \\
2^{\circ} \text { ciclo } \\
\text { EJA I } 1^{\circ} \\
\text { acio }\end{array}$ & & 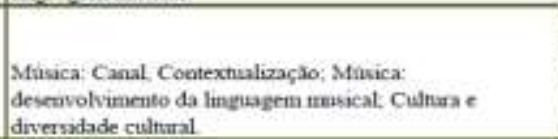 & $\begin{array}{l}\text { alano fi devera ter ferto } \\
\text { suas proprus } \\
\text { observaçles descritivas a } \\
\text { respeiso de drversos } \\
\text { comportamentos. }\end{array}$ & \begin{tabular}{|l|}
2 aulas de \\
50 \\
minutos \\
(Th40 \\
nim)
\end{tabular} & \\
\hline
\end{tabular}




\begin{tabular}{|c|c|c|c|c|c|c|c|c|c|}
\hline 38 & $\begin{array}{l}\text { MÚsICA: } \\
\text { Conposiciolo- } \\
\text { Improvisacto }\end{array}$ & $\begin{array}{l}\text { Rodngo } \\
\text { Russano } \\
\text { Coantor } \\
\text { Claudia } \\
\text { Helena } \\
\text { Azrvedo } \\
\text { Alvirenga } \\
\end{array}$ & $\begin{array}{l}\text { Eucola } \\
\text { Municipal } \\
\text { Alencastro } \\
\text { Guimarnes - Ruo } \\
\text { de Janeiro RJ }\end{array}$ & $\begin{array}{l}\text { EM: EFF, } \\
\text { EJA } 2^{\circ} \\
\text { ciclo }\end{array}$ & Artes & 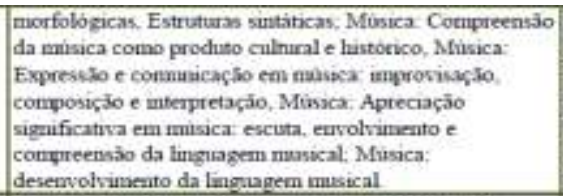 & $\begin{array}{l}\text { conliecumento formal } \\
\text { previo, mas a aula sera } \\
\text { enellhor aproveitada e os } \\
\text { resultados dos trabalios } \\
\text { propostos serho mais } \\
\text { enraquecedores, se os } \\
\text { alunos tiverema }\end{array}$ & $\begin{array}{l}1 \text { unla de } \\
50 \\
\text { minutos }\end{array}$ & 2010 \\
\hline 39 & $\begin{array}{l}\text { Musica : } \\
\text { compassos } \\
\text { temarios - } \\
\text { Leitura e } \\
\text { escrita } 3\end{array}$ & \begin{tabular}{|l|} 
Luciano Cintra \\
Silveina \\
Coautoo \\
Rodrigo \\
Russano \\
\end{tabular} & $\begin{array}{l}\text { Col de Aplic da } \\
\text { Univ Fed do Rio } \\
\text { de Janevo. RJ }\end{array}$ & $\begin{array}{l}\text { EM: EFF: } \\
\text { EJA } 2^{\circ} \\
\text { aclo }\end{array}$ & Artes & 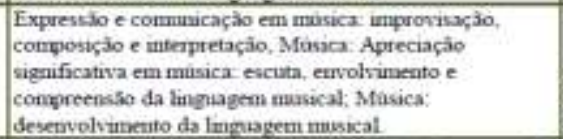 & $\begin{array}{l}\text { Os alumos devem ter } \\
\text { desenvolvidas as nogoses } \\
\text { de pulso e de ten po }\end{array}$ & $\begin{array}{l}1 \text { anb de } \\
\text { so } \\
\text { nintutos. }\end{array}$ & 2010 \\
\hline 40 & $\begin{array}{l}\text { Musica - } \\
\text { Composicio } \\
\text { Imagistica } \\
\text { (parte 5) }\end{array}$ & $\begin{array}{l}\text { Luciano Cintra } \\
\text { Silveiva } \\
\text { Coautor: } \\
\text { Claudia } \\
\text { Helena } \\
\text { Azevedo } \\
\text { Alvarenga } \\
\end{array}$ & $\begin{array}{l}\text { Col de Aplic da } \\
\text { Univ Fed do Rio } \\
\text { de Jaeneiro. RJ }\end{array}$ & $\begin{array}{l}\text { EM, EFF. } \\
\text { EJA } 2^{2} \\
\text { ciclo }\end{array}$ & $\begin{array}{l}\text { Antes: } \\
\text { Matematic } \\
\text { a }\end{array}$ & 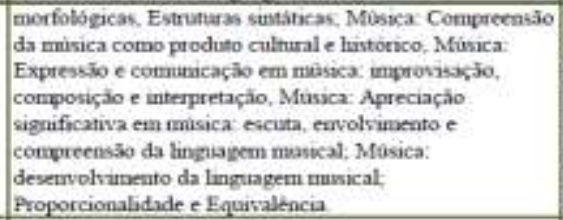 & 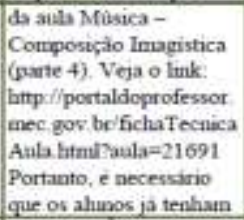 & $\begin{array}{l}1 \text { asala de } \\
50 \\
\text { minutos }\end{array}$ & 2010 \\
\hline 41 & $\begin{array}{l}\text { MUStCA: } \\
\text { Cotaposicso- } \\
\text { Aleatoriedade }\end{array}$ & $\begin{array}{l}\text { Rodingo } \\
\text { Russano } \\
\text { Coautor: } \\
\text { Claudia } \\
\text { Helewa } \\
\text { Azevedo } \\
\text { Alvirenga }\end{array}$ & $\begin{array}{l}\text { Escola } \\
\text { Mumicipal } \\
\text { Alencastro } \\
\text { Caimaraes-Rio } \\
\text { de Janeuso RJ } \\
\end{array}$ & $\begin{array}{l}\text { EM: EFF: } \\
\text { EIA } 2^{*} \\
\text { aclo }\end{array}$ & Antes & 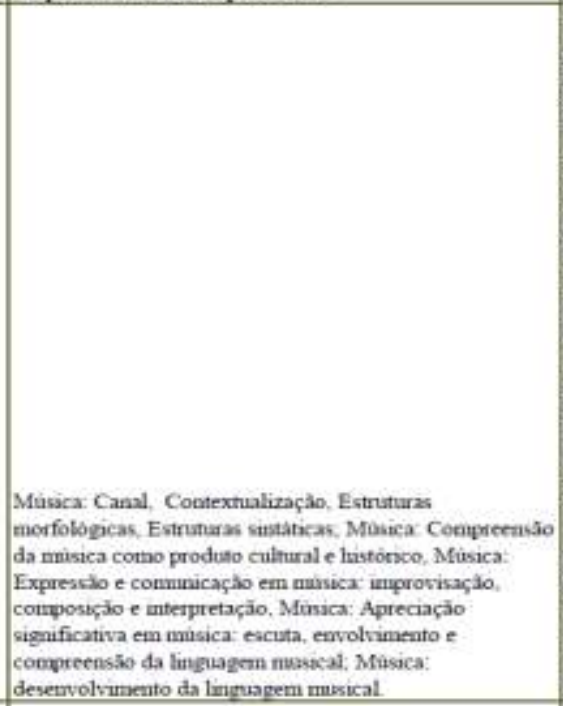 & 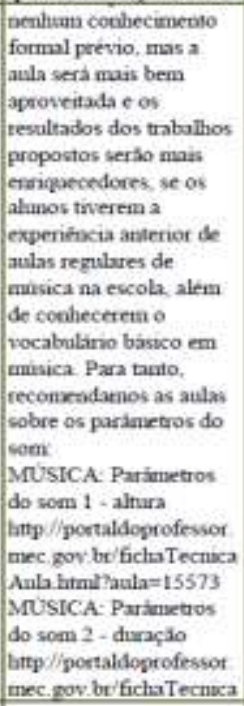 & $\begin{array}{l}1 \text { anla de } \\
\text { so } \\
\text { nimutos }\end{array}$ & 2010 \\
\hline 42 & $\begin{array}{l}\text { Masica - O } \\
\text { conqutador } \\
\text { como } \\
\text { unstruarento } \\
\text { musical (anta } \\
\text { 2): Audacity, o } \\
\text { micio }\end{array}$ & 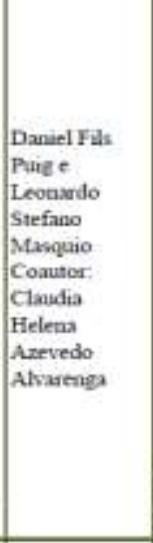 & $\begin{array}{l}\text { Col de Aplic da } \\
\text { Univ Fed do Rio } \\
\text { de Janeiro. RU. }\end{array}$ & $\begin{array}{l}\text { EM: EA } \\
20 \text { ciclo; } \\
\text { Ed Prof; } \\
\text { Ed Escodar } \\
\text { Indigena } \\
\end{array}$ & $\begin{array}{l}\text { Antes: } \\
\text { Produghio } \\
\text { Cultual e } \\
\text { Design }\end{array}$ & 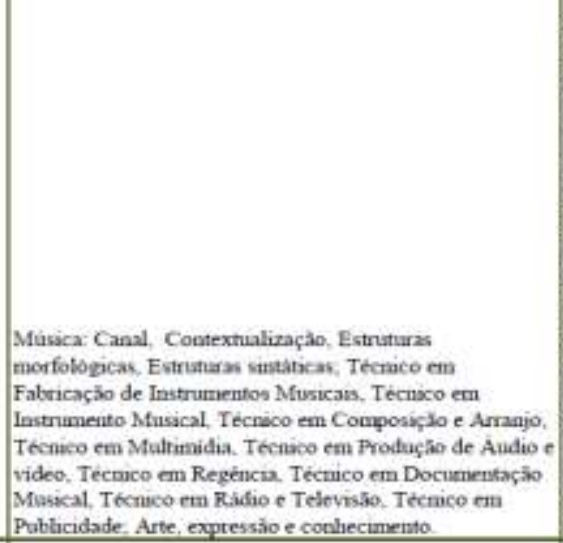 & 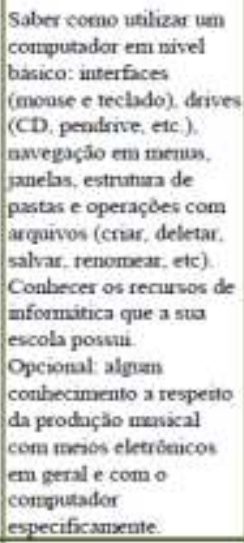 & $\begin{array}{l}2 \text { aulas de } \\
\text { so } \\
\text { munutos } \\
\text { (1b40 } \\
\text { nun) }\end{array}$ & 2010 \\
\hline 43 & $\begin{array}{l}\text { Musica - } \\
\text { Compassos } \\
\text { quaternànos- } \\
\text { Leitura e } \\
\text { escrita } 1 \\
\end{array}$ & $\begin{array}{l}\text { Luciano Cintra } \\
\text { Silveira } \\
\text { Coautor: } \\
\text { Claudia } \\
\text { Helens } \\
\text { Arevedo } \\
\text { Alvareaga } \\
\end{array}$ & $\begin{array}{l}\text { Col de Aplac da } \\
\text { Univ Fed do Rio } \\
\text { de Janeiro, RJ } \\
\end{array}$ & $\begin{array}{l}\text { EM: EFF: } \\
\text { EJA2 } \\
\text { ciclo }\end{array}$ & Antes & 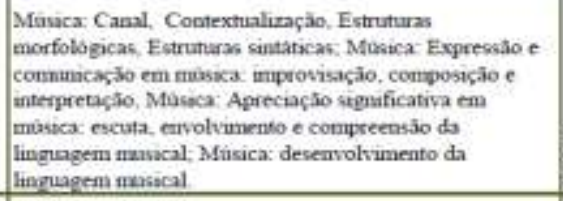 & $\begin{array}{l}\text { Os alubos devem ter } \\
\text { desenvolvidas as nopoles } \\
\text { de palso e de nempo }\end{array}$ & $\begin{array}{l}1 \text { aula de } \\
50 \\
\text { manutos }\end{array}$ & 2010 \\
\hline 44 & $\begin{array}{l}\text { Musica - } \\
\text { conipassos } \\
\text { quaternarios- } \\
\text { Leinua e } \\
\text { escrita } 6\end{array}$ & $\begin{array}{l}\text { Luciano Cintran } \\
\text { Silveira } \\
\text { Coasion: } \\
\text { Clavidia } \\
\text { Helena } \\
\text { Azrvedo } \\
\text { Alvarenga } \\
\end{array}$ & $\begin{array}{l}\text { Col de Aplic da } \\
\text { Unirv Fed do Rio } \\
\text { de Jageno. RJ. }\end{array}$ & $\begin{array}{l}\text { EM: EFF, } \\
\text { EJA } 2^{*} \\
\text { aclo }\end{array}$ & & 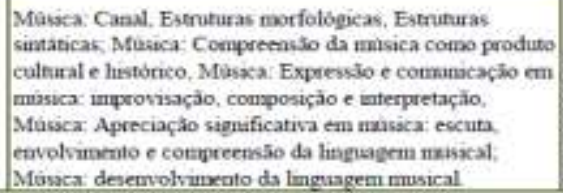 & $\begin{array}{l}\text { Os alunos devem ter } \\
\text { desenvolvidas as nopōes } \\
\text { de pulso e de tempo, } \\
\text { suldivisio do ternyo em } \\
\text { duas e em quatro partes }\end{array}$ & $\begin{array}{l}1 \text { aula de } \\
\text { so } \\
\text { mennotos }\end{array}$ & \\
\hline
\end{tabular}




\begin{tabular}{|c|c|c|c|c|c|c|c|c|c|}
\hline 45 & $\begin{array}{l}\text { Dança de } \\
\text { salào: } \\
\text { Introdução ao } \\
\text { Samba }\end{array}$ & \begin{tabular}{|l|} 
Frederico \\
Marcelo \\
Crochet \\
Coautor. \\
Nelson Vieira \\
da Fonseca \\
Fana \\
\end{tabular} & $\begin{array}{l}\text { Col de Aplic } \\
\text { Joào XXIII- } \\
\text { Juiz de Fora- } \\
\text { MG }\end{array}$ & EM & Artes & $\begin{array}{l}\text { Música: Canal, Contextualizaçâ, Estruturas } \\
\text { morfologicas, Estruturas sintaticas }\end{array}$ & $\begin{array}{l}\text { Nào é necesseario } \\
\text { conhecimento previo }\end{array}$ & $\begin{array}{l}5 \text { aulas de } \\
50 \\
\text { minutos }\end{array}$ & 2012 \\
\hline 46 & $\begin{array}{l}\text { Música - } \\
\text { Expressividade } \\
\text { - Contraste } \\
\text { (parte 2) }\end{array}$ & $\begin{array}{l}\text { Luciano Cintra } \\
\text { Silveira } \\
\text { Coautor. } \\
\text { Claudia } \\
\text { Helena } \\
\text { Azevedo } \\
\text { Alvarenga }\end{array}$ & $\begin{array}{l}\text { Col de Aplic da } \\
\text { Univ Fed do Rio } \\
\text { de Janeiro. RJ. }\end{array}$ & $\begin{array}{l}\text { EM; EFF; } \\
\text { EFI; EJA } \\
2^{\circ} \text { ciclo }\end{array}$ & $\begin{array}{l}\text { Artes; } \\
\text { Matemátic } \\
\text { a }\end{array}$ & 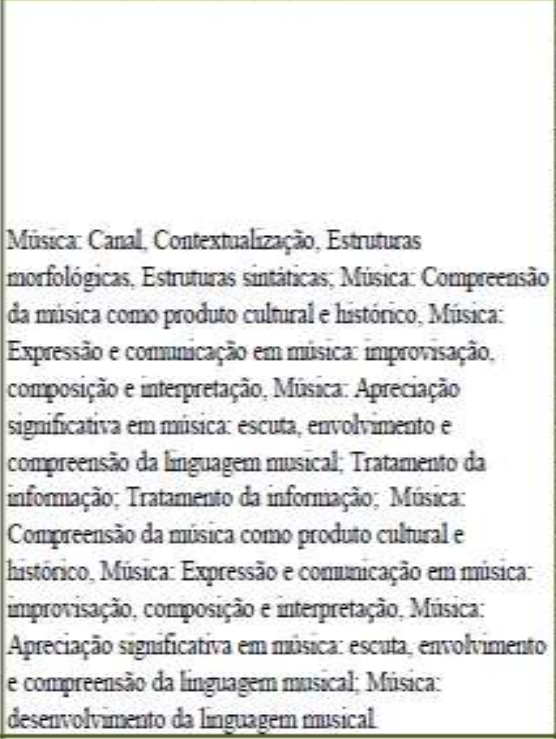 & 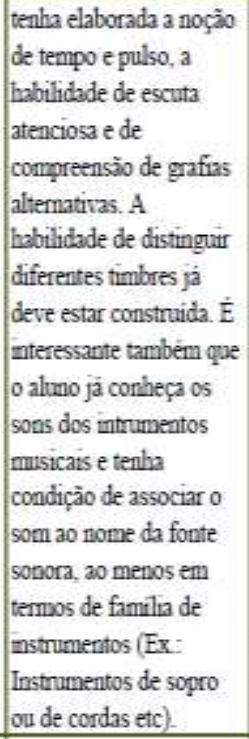 & $\begin{array}{l}1 \text { aula de } \\
50 \\
\text { minutos } \\
\end{array}$ & 2010 \\
\hline 47 & $\begin{array}{l}\text { Música - } \\
\text { compassos } \\
\text { quatemáios - } \\
\text { Leitura e } \\
\text { escrita 2 } \\
\end{array}$ & \begin{tabular}{|l|} 
Luciano Cintra \\
Silveira \\
Coautor. \\
Claudia \\
Helena \\
Azevedo \\
Alvarenga \\
\end{tabular} & $\begin{array}{l}\text { Col de Aplic da } \\
\text { Univ Fed do Rio } \\
\text { de Janeiro. RJ. }\end{array}$ & $\begin{array}{l}\text { EM; EFF; } \\
\text { EJA } 2^{\circ} \\
\text { ciclo }\end{array}$ & Artes & 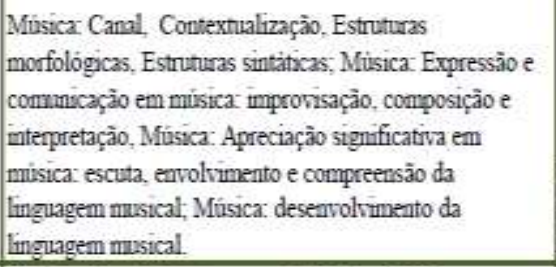 & $\begin{array}{l}\text { Os alunos derem ter } \\
\text { desenvolvidas as nocoóes } \\
\text { de pulso e de tempo }\end{array}$ & $\begin{array}{l}1 \text { aula de } \\
50 \\
\text { minutos }\end{array}$ & 2010 \\
\hline 48 & $\begin{array}{l}\text { Música - } \\
\text { compassos } \\
\text { temários - } \\
\text { Leitura e } \\
\text { escrita } 2\end{array}$ & \begin{tabular}{l|} 
Luciano Cintra \\
Silveira \\
Coantor: \\
Rodrigo \\
Russano
\end{tabular} & $\begin{array}{l}\text { Col de Aplic da } \\
\text { Univ Fed do Rio } \\
\text { de Janeiro. RJ. }\end{array}$ & $\begin{array}{l}\text { EM; EFF; } \\
\text { EJA } 2^{\circ} \\
\text { ciclo }\end{array}$ & Artes & 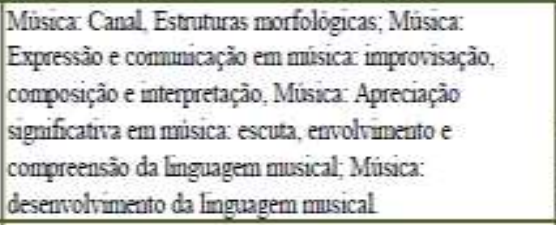 & $\begin{array}{l}\text { Os ahunos derem ter } \\
\text { desenvolvidas as nogões } \\
\text { de pulso e de tenno. }\end{array}$ & $\begin{array}{l}1 \text { aula de } \\
50 \\
\text { minutos } \\
\end{array}$ & 2010 \\
\hline & & & & & & & & & \\
\hline
\end{tabular}




\section{APÊNDICE D - Planilha PB2 Categorias. Amostra de análise até Aula N ${ }^{\circ} 7$}

\begin{tabular}{|c|c|c|c|c|c|c|c|c|c|}
\hline \multirow[b]{2}{*}{$\frac{\pi}{3}$} & \multicolumn{2}{|c|}{ Objetivos } & \multicolumn{2}{|c|}{ Estratégias } & \multicolumn{2}{|c|}{ Recursos } & \multicolumn{3}{|c|}{ Avaliação } \\
\hline & $\begin{array}{l}\text { Descri } \\
\text { ção / } \\
\text { Ação }\end{array}$ & $\begin{array}{c}\text { Foco } \\
\text { (centra } \\
\text { da no } \\
\text { aluno, } \\
\text { no } \\
\text { profess } \\
\text { or ou } \\
\text { no } \\
\text { conteú } \\
\text { do) }\end{array}$ & $\begin{array}{l}\text { Ativida } \\
\text { des } \\
\text { (tipo, } \\
\text { natureza } \\
\text {, Ação } \\
\text { do } \\
\text { professo } \\
\text { r, Ação } \\
\text { do } \\
\text { estudant } \\
\text { e). }\end{array}$ & $\begin{array}{c}\text { Sequen } \\
\text { cia } \\
\text { didátic } \\
\text { a }\end{array}$ & $\begin{array}{c}\text { Ferram } \\
\text { entas } \\
\text { didátic } \\
\text { as } \\
\text { (ativid } \\
\text { ades, } \\
\text { aulas) }\end{array}$ & $\begin{array}{l}\text { Multimídia } \\
\text { (Recursos } \\
\text { com } \\
\text { internet) }\end{array}$ & $\begin{array}{c}\text { Relaçã } \\
\text { o }\end{array}$ & $\begin{array}{l}\text { Instru } \\
\text { mentos }\end{array}$ & Tipo \\
\hline 1 & $\begin{array}{l}\text { Context } \\
\text { ual } \\
- \\
\text { canções } \\
\text { da } \\
\text { Africa } \\
\text { do Sul } \\
\text { - história } \\
\text { e } \\
\text { aspectos } \\
\text { sociais } \\
\text { da A do } \\
\text { Sul } \\
- \\
\text { vivencia } \\
\text { r } \\
- \\
\text { desenvol } \\
\text { ver }\end{array}$ & $\begin{array}{l}- \\
\text { centrada } \\
\text { no } \\
\text { conteúd } \\
\text { o } \\
\text { (formas } \\
\text { musicai } \\
\text { s) }\end{array}$ & $\begin{array}{l}\text { - nota } \\
\text { explicativ } \\
\text { a para o } \\
\text { professor } \\
\text { - } \\
\text { expositiva } \\
\text { (fale, } \\
\text { destaque, } \\
\text { explique, } \\
\text { motive, } \\
\text { ensine, } \\
\text { rege) } \\
\text { - } \\
\text { cinestésic } \\
\text { a }\end{array}$ & $\begin{array}{l}- \\
\text { encadea } \\
\text { da } \\
- \\
\text { sequênci } \\
\text { a } \\
\text { descrita } \\
\text { como } \\
\text { etapas } \\
\text { (ensino } \\
\text { de } \\
\text { canção e } \\
\text { do } \\
\text { movime } \\
\text { nto } \\
\text { corporal } \\
\text { ) }\end{array}$ & $\begin{array}{l}\text { - folhas } \\
\text { de papel } \\
\text { com } \\
\text { letra de } \\
\text { música } \\
\text { ou } \\
\text { partitura }\end{array}$ & $\begin{array}{l}\text { - vídeos } \\
\text { (youtube) } \\
\text { - sites } \\
\text { (wikipedia) } \\
\text { - portal-aula }\end{array}$ & $\begin{array}{l}\text { - relação } \\
\text { com } \\
\text { conteúd } \\
\text { o } \\
\text { - relação } \\
\text { com a } \\
\text { própria } \\
\text { realidad } \\
\text { e }\end{array}$ & $\begin{array}{l}\text { - } \\
\text { aprender } \\
\text { canção } \\
\text { - } \\
\text { aprender } \\
\text { movime } \\
\text { nto } \\
\text { corporal } \\
\text { - debate }\end{array}$ & $\begin{array}{l}\text { Conceit } \\
\text { ual } \\
\text { (canto } \\
\text { respons } \\
\text { orial) }\end{array}$ \\
\hline 2 & $\begin{array}{l}\text { Interdisc } \\
\text { iplinar }\end{array}$ & $\begin{array}{l}\text { centrada } \\
\text { no aluno }\end{array}$ & $\begin{array}{l}\text { - } \\
\text { expositiva } \\
\text { interativa } \\
- \\
\text { cinestésic } \\
\text { a } \\
- \\
\text { investigat } \\
\text { iva }\end{array}$ & $\begin{array}{l}- \\
\text { sequênci } \\
\text { a em } \\
\text { aulas (4) }\end{array}$ & & $\begin{array}{l}\text {-áudio } \\
\text {-vídeo } \\
\text {-software } \\
\text { (simulador) } \\
\text {-sites } \\
\text { (domínio } \\
\text { público) } \\
\text {-BIOE (ova) } \\
\text { Portal }\end{array}$ & $\begin{array}{l}\text { - } \\
\text { compro } \\
\text { vação de } \\
\text { conheci } \\
\text { mentos } \\
\text { prévios } \\
\text { (avaliaç } \\
\text { ão } \\
\text { inicial) }\end{array}$ & $\begin{array}{l}\text { - rubrica } \\
- \\
\text { observaç } \\
\text { ão } \\
\text { continua } \\
\text { e } \\
\text { apresent } \\
\text { ação } \\
\text { final } \\
\text { (instrum } \\
\text { ento } \\
\text { construí } \\
\text { do, } \\
\text { composi } \\
\text { ção, }\end{array}$ & $\begin{array}{l}- \\
\text { Procedi } \\
\text { mental } \\
\text { - Os } \\
\text { estudant } \\
\text { es } \\
\text { sabem } \\
\text { desde } \\
\text { início os } \\
\text { critérios } \\
\text { de } \\
\text { avaliaçã } \\
\text { o }\end{array}$ \\
\hline
\end{tabular}




\begin{tabular}{|c|c|c|c|c|c|c|c|c|c|}
\hline & & & & & & & & $\begin{array}{l}\text { discussã } \\
\text { o) }\end{array}$ & $\begin{array}{l}\text { Uso da } \\
\text { palavra } \\
\text { aluno }\end{array}$ \\
\hline \multirow[t]{2}{*}{3} & \multirow[t]{2}{*}{$\begin{array}{l}\text { - } \\
\text { explorar } \\
\text { - } \\
\text { experim } \\
\text { entar } \\
\text { - criar }\end{array}$} & \multirow[t]{2}{*}{$\begin{array}{l}\text { centrada } \\
\text { no aluno }\end{array}$} & \multirow[b]{2}{*}{$\begin{array}{l}\text { - nota } \\
\text { explicativ } \\
\text { a para o } \\
\text { professor } \\
\text { - } \\
\text { cinestésic } \\
\text { a } \\
\text { - } \\
\text { expositiva } \\
\text { - } \\
\text { dialógica } \\
\text { - os } \\
\text { estudante } \\
\text { s fazem } \\
\text { exploraçã } \\
\text { o e } \\
\text { listagem } \\
\text { de sons } \\
\text { - o } \\
\text { professor } \\
\text { faz } \\
\text { questões } \\
\text { fechadas } \\
\text {-os alunos } \\
\text { responde } \\
\text { m sim ou } \\
\text { não. }\end{array}$} & \multirow[b]{2}{*}{$\begin{array}{l}- \\
\text { especifi } \\
\text { ca-se } \\
\text { como } \\
\text { conheci } \\
\text { mento } \\
\text { prévio } \\
\text { (sem } \\
\text { conheci } \\
\text { mentos } \\
\text { formais } \\
\text { em } \\
\text { música) } \\
\text { - } 1^{\text {a aula }} \\
\text { de uma } \\
\text { coleção } \\
\text { - } 4 \\
\text { atividad } \\
\text { es na } \\
\text { mesma } \\
\text { aula } \\
- \\
\text { exercíci } \\
\text { os de } \\
\text { improvi } \\
\text { sação } \\
\text { sequenci } \\
\text { as. }\end{array}$} & & \multirow[t]{2}{*}{$\begin{array}{l}\text { - fotos } \\
\text { - vídeo } \\
\text { (youtube) } \\
\text { - sites } \\
\text { - portal-aula }\end{array}$} & \multirow{2}{*}{$\begin{array}{l}\text { - } \\
\text { parâmet } \\
\text { ros } \\
\text { diferent } \\
\text { es aos } \\
\text { objetivo } \\
\text { s }\end{array}$} & \multirow{2}{*}{$\begin{array}{l}\text { - } \\
\text { produçã } \\
\text { o } \\
- \\
\text { observaç } \\
\text { ão de } \\
\text { resultado } \\
\text { s }\end{array}$} & $\begin{array}{l}\text { Procedi } \\
\text { mental }\end{array}$ \\
\hline & & & & & & & & & $\begin{array}{l}\text { Uso da } \\
\text { palavra } \\
\text { aluno }\end{array}$ \\
\hline \multirow[t]{2}{*}{4} & \multirow{2}{*}{$\begin{array}{l}\text { - } \\
\text { conceito } \\
\text { pulso e } \\
\text { compass } \\
\text { o } \\
\text { - } \\
\text { desenvol } \\
\text { ver } \\
\text { - } \\
\text { aprofund } \\
\text { ar } \\
\text { - } \\
\text { compree } \\
\text { nder } \\
\text { - } \\
\text { conceitu } \\
\text { ar }\end{array}$} & \multirow{2}{*}{$\begin{array}{l}\text { Centrad } \\
\text { a no } \\
\text { conteúd } \\
\text { o } \\
\text { - } \\
\text { letrame } \\
\text { nto } \\
\text { rítmico } \\
\text { (gramáti } \\
\text { ca, } \\
\text { PCN+ } \\
\text { p.42) }\end{array}$} & \multirow{2}{*}{$\begin{array}{l}\text { - nota } \\
\text { explicativ } \\
\text { a para o } \\
\text { professor, } \\
\text { conceitos } \\
\text { e } \\
\text { descrição } \\
\text { detalhada } \\
\text { para } \\
\text { realizar a } \\
\text { aula passo } \\
\text { a passo. } \\
\text { - } \\
\text { imitação, } \\
\text { repetição } \\
\text { nos } \\
\text { estudante } \\
\text { s. } \\
\text { - os } \\
\text { estudante } \\
\text { s } \\
\text { executam } \\
\text { as ordens } \\
\text { do }\end{array}$} & \multirow{2}{*}{$\begin{array}{l}\text { especifi } \\
\text { ca-se } \\
\text { como } \\
\text { conheci } \\
\text { mento } \\
\text { prévio } \\
\text { conceito } \\
\text { s de aula } \\
\text { anterior } \\
\text { - } \\
\text { atividad } \\
\text { es em } \\
\text { sequênci } \\
\text { a }\end{array}$} & \multirow[t]{2}{*}{ - livro } & \multirow[t]{2}{*}{$\begin{array}{l}\text { - site } \\
\text { - wiki } \\
\text { - portal-aula }\end{array}$} & \multirow{2}{*}{$\begin{array}{l}\text { Relação } \\
\text { com } \\
\text { conceito } \\
\text { s } \\
\text { (aquisiç } \\
\text { ão de } \\
\text { saberes) }\end{array}$} & \multirow{2}{*}{$\begin{array}{l}\text { - } \\
\text { observaç } \\
\text { ão da } \\
\text { realizaçã } \\
\text { o de } \\
\text { exercício } \\
\text { s } \\
\text { (resultad } \\
\text { os) }\end{array}$} & $\begin{array}{l}\text { Conceit } \\
\text { ual }\end{array}$ \\
\hline & & & & & & & & & $\begin{array}{l}\text { Uso da } \\
\text { palavra } \\
\text { aluno }\end{array}$ \\
\hline
\end{tabular}




\begin{tabular}{|c|c|c|c|c|c|c|c|c|c|}
\hline & & & $\begin{array}{l}\text { professor } \\
\text { professor }\end{array}$ & & & & & & \\
\hline 5 & $\begin{array}{l}\text { Interdisc } \\
\text { iplinar } \\
\text { - refletir } \\
\text { - } \\
\text { compree } \\
\text { nder }\end{array}$ & $\begin{array}{l}\text { Centrad } \\
\text { a no } \\
\text { tema/co } \\
\text { nteúdo } \\
\text { (estudos } \\
\text { sociais) }\end{array}$ & $\begin{array}{l}\text { - } \\
\text { interativa } \\
\text { (question } \\
\text { amentos } \\
\text { provocad } \\
\text { os a partir } \\
\text { de vídeo) } \\
\text { - } \\
\text { dialógica } \\
\text { (discussã } \\
\text { o, } \\
\text { busca,esc } \\
\text { olha) } \\
\text { - o } \\
\text { professor } \\
\text { tem em } \\
\text { conta o } \\
\text { contexto } \\
\text { dos } \\
\text { estudante } \\
\text { s } \\
\text { - debate } \\
\text { entre } \\
\text { estudante } \\
\text { s } \\
\text { - } \\
\text { apresenta } \\
\text { ção à } \\
\text { comunida } \\
\text { de }\end{array}$ & $\begin{array}{l}\text { - } \\
\text { atividad } \\
\text { es em } \\
\text { sequênci } \\
\text { a para } \\
\text { cada } \\
\text { aula }\end{array}$ & $\begin{array}{l}\text { Sugere- } \\
\text { se: } \\
\text { - folhas } \\
\text { de papel } \\
\text { impress } \\
\text { o } \\
\text { - } \\
\text { retroproj } \\
\text { etor } \\
\text { - } \\
\text { imagem } \\
\text { (wiki) } \\
\text { - uso de } \\
\text { dispositi } \\
\text { vos e } \\
\text { formato } \\
\text { s de } \\
\text { áudio e } \\
\text { gravaçã } \\
\text { o }\end{array}$ & $\begin{array}{l}\text { - vídeo/site } \\
\text { portal } \\
\text { (acompanhad } \\
\text { o de descrição } \\
\text { de objetivo) } \\
\text { - site } \\
\text { (letras.terra.co } \\
\text { m; } \\
\text { min.transport } \\
\text { es.br.df; } \\
\text { Portal } \\
\text { educacional; } \\
\text { revist; } \\
\text { wikipedia). }\end{array}$ & $\begin{array}{l}- \\
\text { critérios } \\
\text { acordad } \\
\text { os } \\
\text { professo } \\
\text { r e } \\
\text { estudant } \\
\text { es) }\end{array}$ & $\begin{array}{l}\text { - } \\
\text { registros } \\
\text { escritos } \\
\text { - } \\
\text { produçõ } \\
\text { es } \\
\text { musicais }\end{array}$ & $\begin{array}{l}- \\
\text { Procedi } \\
\text { mental } \\
- \\
\text { Atitudin } \\
\text { al } \\
\text { (reflexã } \\
\text { o, senso } \\
\text { crítico, } \\
\text { respeito } \\
\text { ) } \\
\text { Uso da } \\
\text { palavra } \\
\text { aluno e } \\
\text { estudant } \\
\text { e }\end{array}$ \\
\hline 6 & $\begin{array}{l}\text { - utilizar } \\
\text { - } \\
\text { interpret } \\
\text { ar } \\
\text { (melodía } \\
\text { ) } \\
\text { - criar } \\
\text { (rondó) }\end{array}$ & $\begin{array}{l}\text { Centrad } \\
\text { a no } \\
\text { conteúd } \\
\text { o e no } \\
\text { aluno }\end{array}$ & $\begin{array}{l}\text { - } \\
\text { cinestésic } \\
\text { a } \\
- \\
\text { explicaçã } \\
\text { o } \\
\text { detalhada } \\
\text { das } \\
\text { atividades } \\
\text { e os } \\
\text { objetivos } \\
\text { de elas } \\
\text { - }\end{array}$ & $\begin{array}{l}\text { - } \\
\text { continua } \\
\text { ção de } 4 \\
\text { aulas } \\
\text { anterior } \\
\text { es } \\
\text { - } \\
\text { atividad } \\
\text { es em } \\
\text { sequênci } \\
\text { a }\end{array}$ & & $\begin{array}{l}\text { - portal-aula } \\
\text { - vídeos } \\
\text { (vimeo, } \\
\text { youtube) } \\
\text { - site } \\
\text { (bbc.co.uk/pr } \\
\text { ogrammes; } \\
\text { sescsp.org.br; } \\
\text { barbatuques.c } \\
\text { om.br ) } \\
\text { - audio } \\
\text { (aplicativo- } \\
\text { CBS }\end{array}$ & $\begin{array}{l}\text { Relação } \\
\text { as } \\
\text { atividad } \\
\text { es }\end{array}$ & $\begin{array}{l}\text { Observa } \\
\text { ção } \\
\text { (implícit } \\
\text { a) dos } \\
\text { resultado } \\
\text { s: } \\
\text { realizaçã } \\
\text { o, } \\
\text { participa } \\
\text { ção, } \\
\text { estrutura } \\
\text { ção } \\
\text { musical, }\end{array}$ & $\begin{array}{l}\text { conceitu } \\
\text { al }\end{array}$ \\
\hline
\end{tabular}




\begin{tabular}{|c|c|c|c|c|c|c|c|c|}
\hline & & & $\begin{array}{l}\text { expositiva } \\
\text { (ação do } \\
\text { professor: } \\
\text { relembre } \\
\text { conteúdos } \\
\text {, escolha, } \\
\text { peça). } \\
\text { - os } \\
\text { estudante } \\
\text { s fazem } \\
\text { listagem } \\
\text { de sons, } \\
\text { inventário } \\
\text { e } \\
\text { classificaç } \\
\text { ão. } \\
\text { - o } \\
\text { professor } \\
\text { questiona } \\
\text { sobre } \\
\text { conceitos. } \\
\text { - } \\
\text { atividade } \\
\text { como } \\
\text { melodia } \\
\text { em tom } \\
\text { maior } \\
\text { - os } \\
\text { estudante } \\
\text { s aplicam } \\
\text { listagem }\end{array}$ & & $\begin{array}{l}\text { Interactive } \\
\text { Last.fm) }\end{array}$ & & $\begin{array}{l}\text { organiza } \\
\text { ção do } \\
\text { grupo }\end{array}$ & $\begin{array}{l}\text { Uso da } \\
\text { palavra } \\
\text { aluno }\end{array}$ \\
\hline 7 & $\begin{array}{l}\text { - Criar, } \\
\text { - } \\
\text { desenvol } \\
\text { ver } \\
\text { - } \\
\text { compor }\end{array}$ & $\begin{array}{l}- \\
\text { centrada } \\
\text { no aluno }\end{array}$ & $\begin{array}{l}\text { - } \\
\text { expositiva } \\
\text { numa } 1^{\mathrm{a}} \\
\text { parte; } \\
\text { numa } 2^{\mathrm{a}} \\
\text { parte há } \\
\text { traços } \\
\text { investigat } \\
\text { ivos onde } \\
\text { o } \\
\text { professor } \\
\text { é orienta } \\
\text { (escolha e } \\
\text { construçã } \\
\text { o de } \\
\text { instrumen } \\
\text { tos) } \\
\text { - o } \\
\text { professor } \\
\text { questiona } \\
\text { (conceitos }\end{array}$ & $\begin{array}{l}- \\
\text { explicaç } \\
\text { ão e } \\
\text { descriçã } \\
\text { o } \\
\text { sequenci } \\
\text { al de } \\
\text { atividad } \\
\text { es a ser } \\
\text { seguidas } \\
\text { pelo } \\
\text { professo } \\
\text { r } \\
\text { - }\end{array}$ & $\begin{array}{l}\text { - sites } \\
\text { (wikipedia, } \\
\text { blog) } \\
\text {-software } \\
\text { (simulador) } \\
\text { portal-Rived } \\
\text {-- vídeos } \\
\text { (youtube) } \\
\text { - áudio } \\
\text { (escola SEED } \\
\text { portal) }\end{array}$ & $\begin{array}{l}\text { - relação } \\
\text { com } \\
\text { objetivo } \\
\text { s e } \\
\text { atividad } \\
\text { es } \\
\text { - } \\
\text { descriçã } \\
\text { o clara } \\
\text { dos } \\
\text { conteúd } \\
\text { os da } \\
\text { avaliaçã } \\
\text { o }\end{array}$ & $\begin{array}{l}\text { - } \\
\text { Observa } \\
\text { ção } \\
\text { inicial } \\
\text { - } \\
\text { avaliaçã } \\
\text { o } \\
\text { continua }\end{array}$ & $\begin{array}{l}\text { - } \\
\text { Procedi } \\
\text { mental } \\
\text { (compre } \\
\text { ensão, } \\
\text { particip } \\
\text { ação) } \\
\text { - } \\
\text { atitudin } \\
\text { al } \\
\text { (interess } \\
\text { e, } \\
\text { interaçã } \\
\text { o) } \\
\text { - } \\
\text { conceitu } \\
\text { al } \\
\text { (compre } \\
\text { ensão } \\
\text { do } \\
\text { conceito }\end{array}$ \\
\hline
\end{tabular}




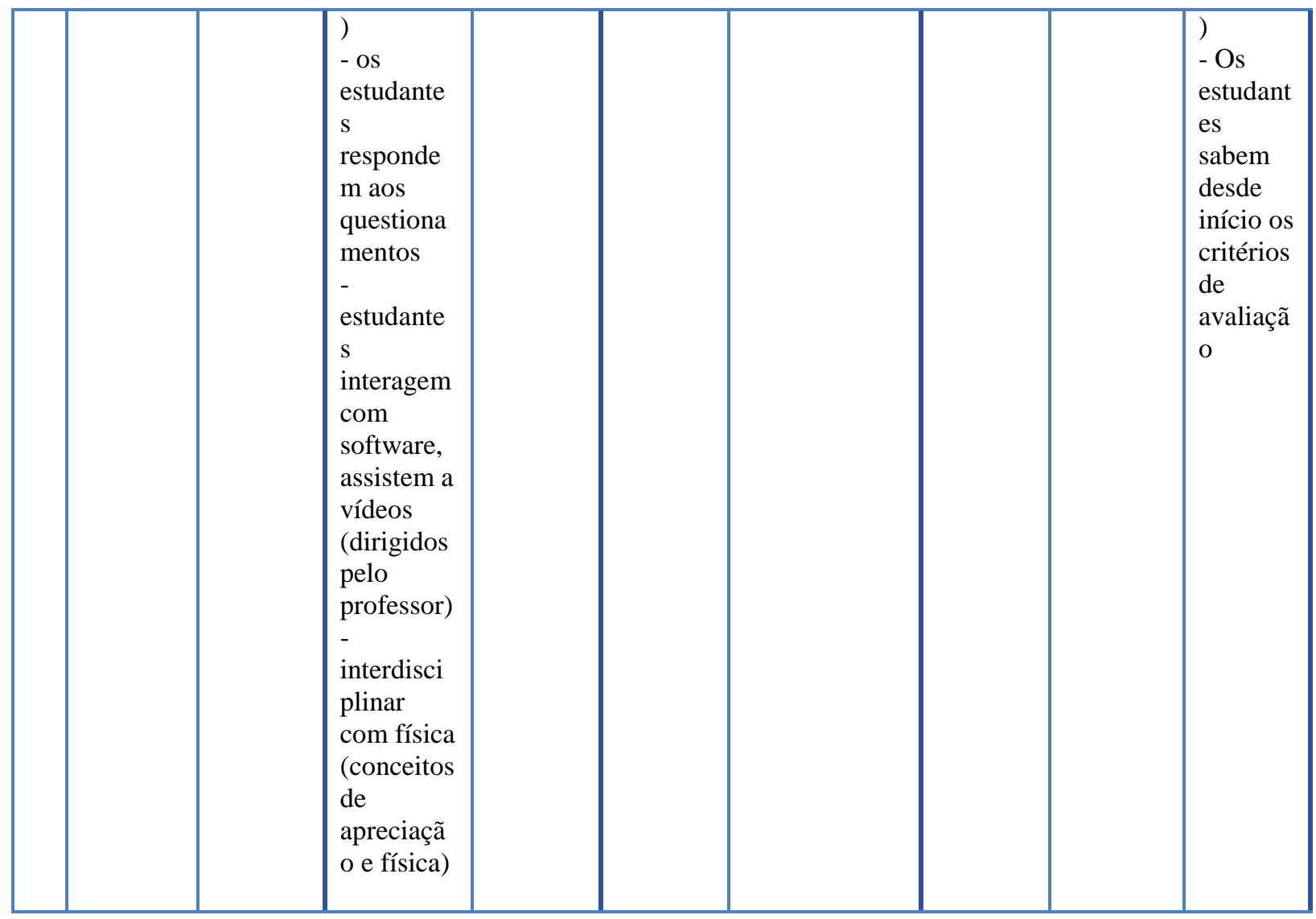


ANEXO A - Classificação de "modelos didáticos" elaborado por García Pérez (2000 p. 28)

\begin{tabular}{|c|c|c|c|c|}
\hline $\begin{array}{l}\text { DIMENSIONES } \\
\text { ANAUTADAS }\end{array}$ & $\begin{array}{l}\text { MOOZO DIDNCIICO } \\
\text { TRADICIONAL }\end{array}$ & $\begin{array}{l}\text { MODELO DDictico } \\
\text { TECNOLCEXO }\end{array}$ & $\begin{array}{l}\text { MODGO DDIETCO } \\
\text { ESPONTANEISTA }\end{array}$ & $\begin{array}{c}\text { MODAO DDICTICO ALTEBSATNO } \\
\text { (Modela de ime-tigsaín } \\
\text { en la Ecouels) }\end{array}$ \\
\hline Para qué enseñar & $\begin{array}{l}\text { - Proporcionar la informs- } \\
\text { cionesfundamertales dela } \\
\text { cultura vigente. } \\
\text { - Obsesión por los con- } \\
\text { tenidos }\end{array}$ & $\begin{array}{l}\text { - Proporcionar una formación } \\
\text { modernan y ecficazs. } \\
\text { - Obsesiōn por los objetivos. } \\
\text { - Se sigue una programación } \\
\text { detalada. }\end{array}$ & $\begin{array}{l}\text { - Educar al alumno imbuyén. } \\
\text { dolo de la resiidad inmedista. } \\
\text { - Importancia del factor ideo. } \\
\text { lógico. }\end{array}$ & $\begin{array}{l}\text { - Enciquecimiento progresiva del co- } \\
\text { nocimierto del alumo hacia mode- } \\
\text { las mis complejos de entender el } \\
\text { mundo y de actuar en el. } \\
\text { - Importancia de la opción educati- } \\
\text { va que se tome. }\end{array}$ \\
\hline Qué enser̃ar & $\begin{array}{l}\text { - Sintesis del saber disci- } \\
\text { plinar. } \\
\text { - Predominio de las infor- } \\
\text { macioness de carácter } \\
\text { conceptual. }\end{array}$ & $\begin{array}{l}\text { - Saberes disciplinares actial. } \\
\text { zados, con incorporación deal. } \\
\text { gunos conocimientos no } \\
\text { disciplinsres. } \\
\text { - Conteridos preparados por } \\
\text { expertos para ser utlizados por } \\
\text { los protesores. } \\
\text { - Importancia de lo conceptual, } \\
\text { pero otorgando tarnbién cierta } \\
\text { rdevancia a las destrezas. }\end{array}$ & $\begin{array}{l}\text { - Conteridos preventes on la } \\
\text { reslidad inmediata. } \\
\text { - Importancia de las destreras } \\
\text { y las actitudes. }\end{array}$ & 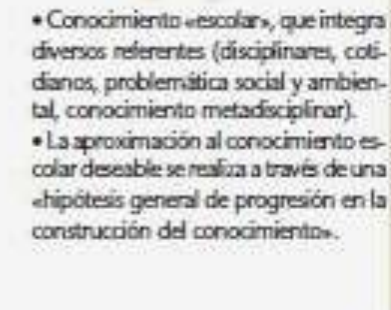 \\
\hline $\begin{array}{l}\text { Ideas e intereses } \\
\text { de los alumnos }\end{array}$ & $\begin{array}{l}\text { - No se tienen en cuenta } \\
\text { ni los intereses ni las idess } \\
\text { de los dumnos. }\end{array}$ & $\begin{array}{l}\text { - No se tienen en cuenta los in- } \\
\text { tereses de los alumnos. } \\
\text { - A veces se tienen en cuenta } \\
\text { las ideas de ins alumnos cons. } \\
\text { deràndolas como uerores que } \\
\text { hay que suatituir por los cono- } \\
\text { cimientos adecuados. }\end{array}$ & $\begin{array}{l}\text { - Se tenen en cuenta los intero } \\
\text { ses inmediatos de los siumnos. } \\
\text { - No se tienen en cuenta las } \\
\text { ideas de los alumnos. }\end{array}$ & $\begin{array}{l}\text { - Se tienen en cuenta los intereses y } \\
\text { las ideas de los ajumnos, tanto en re- } \\
\text { lación con el conocimiento propues } \\
\text { to como en relación con la construc- } \\
\text { ción de ese conocimiento. }\end{array}$ \\
\hline Cormo enseñar & 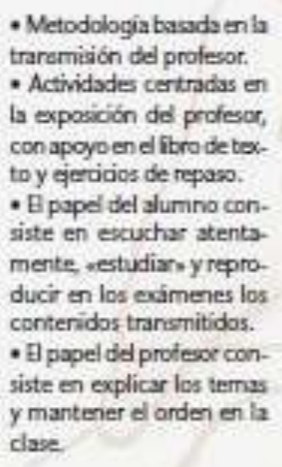 & 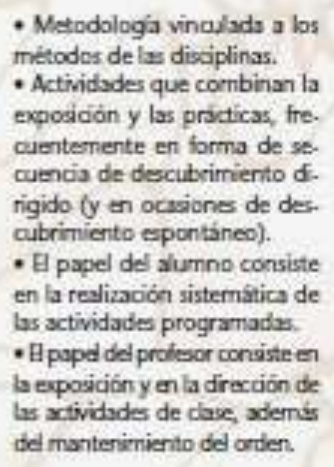 & 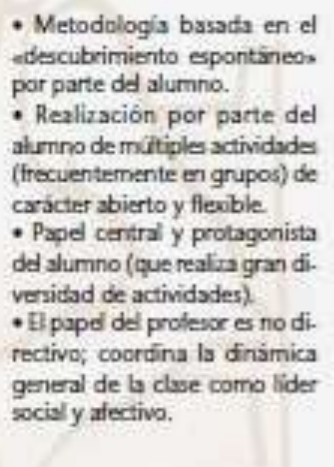 & 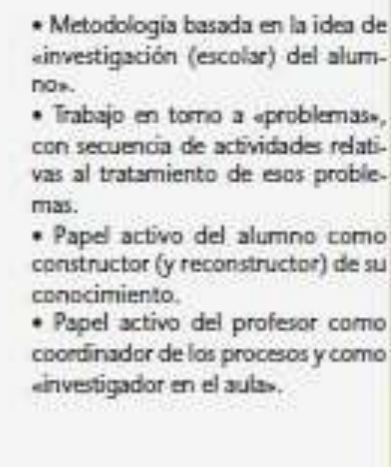 \\
\hline Evaluación & $\begin{array}{l}\text { - Ceritrada er secoordas los } \\
\text { conteridos transmitidos, } \\
\text { - Atiende, sobre todo, al } \\
\text { proctucto. } \\
\text { - Reslizada mediante exs- } \\
\text { menes. }\end{array}$ & $\begin{array}{l}\text { - Cenitrada en la medición de. } \\
\text { tallada de los aprondizajes. } \\
\text { Atiende al producto, pero se in- } \\
\text { tenta medir algumos procesas } \\
\text { (p.e. test inicial y final). } \\
\text { - Realizada mediante tests y } \\
\text { ejercicios especificos. }\end{array}$ & 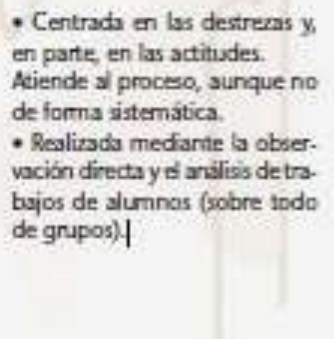 & 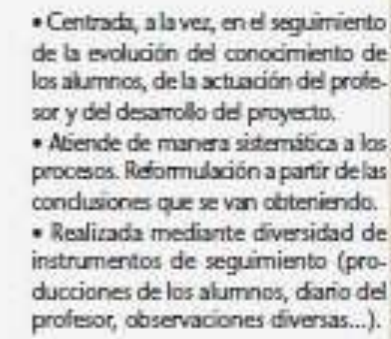 \\
\hline
\end{tabular}




\section{ANEXO B - Classificação de "modelos didáticos" elaborado por María Cecilia Jorquera (2010 pp. 68-70)}

TABLA N ${ }^{\circ}$

CONCEPCIONES DE LOS FDUCADORES MUSICALES SOBRE LAS DIFERENTES DIMENSIONES DEL CONOCIMIENTO ESCOLAR QUE DETERMINAN MODELOS DIDÁCTICOS

\begin{tabular}{|c|c|c|c|c|}
\hline $\begin{array}{c}\text { Dimensiones } \\
\text { analizadas }\end{array}$ & $\begin{array}{c}\text { Modelo } \\
\text { Académico }\end{array}$ & $\begin{array}{c}\text { Modelo } \\
\text { Práctico }\end{array}$ & $\begin{array}{c}\text { Modelo } \\
\text { Comunicativo } \\
\text { Lúdico }\end{array}$ & $\begin{array}{c}\text { Modelo } \\
\text { Complejo }\end{array}$ \\
\hline Para qué enseñar & $\begin{array}{c}\text { Integrar la música } \\
\text { en la red de } \\
\text { conocimientos } \\
\text { acerca de la } \\
\text { cultura. }\end{array}$ & $\begin{array}{c}\text { Conocer un } \\
\text { quehacer artístico } \\
\text { propio de la } \\
\text { cultura y las } \\
\text { vivencias afectivas } \\
\text { que puede } \\
\text { suscitar. }\end{array}$ & $\begin{array}{c}\text { Conocer un } \\
\text { quehacer propio } \\
\text { de la cultura } \\
\text { accediendo a } \\
\text { algunos de sus } \\
\text { significados. } \\
\text { Participar en } \\
\text { experiencias } \\
\text { artistico-musicales } \\
\text { y creativas. }\end{array}$ & $\begin{array}{c}\text { Conocer y } \\
\text { comprender las } \\
\text { culturas } \\
\text { conocimientento } \\
\text { humano } \\
\text { contextualizado. }\end{array}$ \\
\hline
\end{tabular}

\begin{tabular}{|c|c|c|c|c|}
\hline Qhui mustiar & $\begin{array}{l}\text { Másica como } \\
\text { objeto. } \\
\text { Música como } \\
\text { ciencia. } \\
\text { Visión estética } \\
\text { formalisea de la } \\
\text { mitsica. } \\
\text { Estrucuara en la } \\
\text { mulsica. }\end{array}$ & $\begin{array}{l}\text { Queharer prartico. } \\
\text { Experiencia } \\
\text { subjeriva } y / o \\
\text { afectiva individual. } \\
\text { La musica es } \\
\text { agradable. } \\
\text { Es produrto de la } \\
\text { percepcion. }\end{array}$ & $\begin{array}{l}\text { Es comunicación. } \\
\text { Fs un lenguaje. } \\
\text { Es espectarculo. }\end{array}$ & $\begin{array}{c}\text { Conducta } \\
\text { humana } \\
\text { contextualizada, } \\
\text { con significados, } \\
\text { funciones y } \\
\text { realizada en } \\
\text { contextos } \\
\text { especificos por } \\
\text { unas perwonas } \\
\text { (intérpretes) para } \\
\text { otras (cyentes). }\end{array}$ \\
\hline $\begin{array}{l}\text { Ideas e inlerses } \\
\text { de los dhumnos }\end{array}$ & $\begin{array}{l}\text { No se dienen en } \\
\text { cuenta ideas ni } \\
\text { intereses de kvs } \\
\text { alumnos. }\end{array}$ & $\begin{array}{c}\text { No se tienen en } \\
\text { cuenta ixteas ni } \\
\text { intereses de los } \\
\text { alumnos. }\end{array}$ & $\begin{array}{c}\text { Se tienen en } \\
\text { cuenta los intereses } \\
\text { inmediatos de los } \\
\text { alumnos. } \\
\text { Las ideas no son } \\
\text { tenidas en cuenta. }\end{array}$ & $\begin{array}{l}\text { Ideas e intereses } \\
\text { son senidos en } \\
\text { cuerita en } \\
\text { relación con el } \\
\text { conocimienso } \\
\text { propuesto y con } \\
\text { la construcrion } \\
\text { del mismo. }\end{array}$ \\
\hline Cómo muctiar & 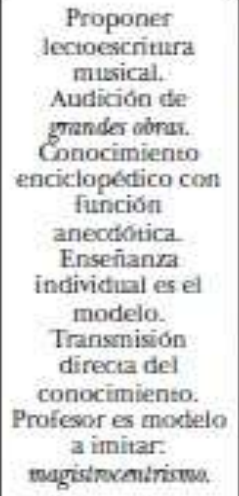 & $\begin{array}{c}\text { Cantar y socar } \\
\text { instrumentos. } \\
\text { Debe ser agrada- } \\
\text { ble. } \\
\text { Procince sarisfac- } \\
\text { cion personal. } \\
\text { Profesor es modelo } \\
\text { a initar: } \\
\text { magistrocentrisuo. } \\
\text { Actividartes } \\
\text { creativas } \\
\text { descontexunalizartas. } \\
\text { Enseñanza } \\
\text { individuat y } \\
\text { ocasionalmente } \\
\text { grupal. }\end{array}$ & $\begin{array}{c}\text { Debe gustar. } \\
\text { Debe entretener y } \\
\text { hacer espectaculo. } \\
\text { Debe ser ameno. } \\
\text { Rol central del } \\
\text { juego, } \\
\text { Motivar. } \\
\text { Trabajo grupal y } \\
\text { colertivo, } \\
\text { destacando la } \\
\text { paricipación en } \\
\text { actividades } \\
\text { creativas. } \\
\text { Paidocritrisma. }\end{array}$ & $\begin{array}{c}\text { Imestigacion } \\
\text { sobre significados, } \\
\text { contexto, } \\
\text { funciones y } \\
\text { estrucuira de } \\
\text { productos } \\
\text { musicales } \\
\text { seleccionados. } \\
\text { El profesor gufa } \\
\text { la construccion } \\
\text { del conocimiento } \\
\text { musical mediante } \\
\text { investigacion y } \\
\text { procesos } \\
\text { creativos. }\end{array}$ \\
\hline Cómo se appende & $\begin{array}{c}\text { Asimilar conceptos. } \\
\text { Conocer la } \\
\text { lectoescrimra } \\
\text { musical. } \\
\text { Conocer la teorlis } \\
\text { musical. } \\
\text { Imitar y repetir } \\
\text { los modelos } \\
\text { propueseos por el } \\
\text { profesor. }\end{array}$ & $\begin{array}{l}\text { Cantar y socar } \\
\text { inserumentos. } \\
\text { Experiencia } \\
\text { personal. } \\
\text { Sentimiensos scin } \\
\text { relevantes; } \\
\text { disfrute. }\end{array}$ & $\begin{array}{c}\text { Expresar } \\
\text { sentimientos } \\
\text { mediante musica. } \\
\text { Cantar, tocar } \\
\text { instrumentos y } \\
\text { participar en } \\
\text { actividades } \\
\text { creativas. } \\
\text { Juegos son } \\
\text { determinantes, } \\
\text { Entretención y } \\
\text { esperticulo. }\end{array}$ & $\begin{array}{c}\text { Vivenciar } \\
\text { experiencias } \\
\text { musicales pard } \\
\text { conocery } \\
\text { comprender las } \\
\text { expresiones y } \\
\text { manifestaciones } \\
\text { musicales de una } \\
\text { cultura, constru- } \\
\text { yendo el } \\
\text { conocimiento a } \\
\text { partir de las jdeas } \\
\text { yel conocimiento } \\
\text { inicial. }\end{array}$ \\
\hline
\end{tabular}




\begin{tabular}{|c|c|c|c|c|}
\hline $\begin{array}{l}\text { Dimensiones } \\
\text { analizadas }\end{array}$ & $\begin{array}{l}\text { Modelo } \\
\text { Académico }\end{array}$ & $\begin{array}{l}\text { Modelo } \\
\text { Práctico }\end{array}$ & $\begin{array}{c}\text { Modelo } \\
\text { Comunicativo } \\
\text { Ladico }\end{array}$ & $\begin{array}{l}\text { Modelo } \\
\text { Complejo }\end{array}$ \\
\hline Eauhacion & $\begin{array}{l}\text { Evaluarión de } \\
\text { resultados por } \\
\text { medio de } \\
\text { exámenes o } \\
\text { andiciones. }\end{array}$ & $\begin{array}{l}\text { Evaluación de } \\
\text { resultados por } \\
\text { medio de } \\
\text { exámenes } 0 \\
\text { austiciones. }\end{array}$ & $\begin{array}{l}\text { Evaluación de: } \\
\text { algunos procesos y } \\
\text { de resultados. } \\
\text { Tareas de } \\
\text { resolución de } \\
\text { problemas. }\end{array}$ & $\begin{array}{l}\text { Evaluación de } \\
\text { proceses y } \\
\text { resulados, } \\
\text { mediante } \\
\text { diferentes } \\
\text { herramientas. }\end{array}$ \\
\hline Currizulum & $\begin{array}{l}\text { Preexiste. } \\
\text { Los conocimientos } \\
\text { son escallecidos } \\
\text { por autoridades } \\
\text { competentes. } \\
\text { Conocimiento } \\
\text { consolidarto por la } \\
\text { tradición, con } \\
\text { caraicter dbjetita. } \\
\text { Estudio de } \\
\text { repertorio (gramiles } \\
\text { abros). }\end{array}$ & $\begin{array}{c}\text { Preexiste. } \\
\text { Los conocimientros } \\
\text { consisten en una } \\
\text { selección de } \\
\text { repertorio } \\
\text { (rectertorio rscolar). } \\
\text { Actividades } \\
\text { creativas } \\
\text { desconternalinadas, } \\
\text { para el aprendizaje } \\
\text { Lếcnicr-musical. } \\
\text { Elección de } \\
\text { materiales es } \\
\text { determinante. }\end{array}$ & $\begin{array}{l}\text { Conocimientos son } \\
\text { parcialmente } \\
\text { seleccionados por } \\
\text { el profesor. } \\
\text { Géneros musicales } \\
\text { conocidos por los } \\
\text { alumnos son } \\
\text { incluidos. }\end{array}$ & $\begin{array}{l}\text { Los conocimien- } \\
\text { tos son seleccio- } \\
\text { nados en función } \\
\text { de las competen- } \\
\text { cias, conocimien- } \\
\text { tos y necesidades } \\
\text { de aprendizaje } \\
\text { de los alumnos. }\end{array}$ \\
\hline $\begin{array}{l}\text { Rolarimas } \\
\text { sistewa escolor- } \\
\text { sidema social }\end{array}$ & $\begin{array}{c}\text { El aula es } \\
\text { independiente del } \\
\text { sistema social. } \\
\text { La enseñanza } \\
\text { mussical es nentra. } \\
\text { Los valores son } \\
\text { enseniarios en } \\
\text { ambito familiar. } \\
\text { Asignarura } \\
\text { María". }\end{array}$ & $\begin{array}{c}\text { El anta es } \\
\text { relativamente } \\
\text { independiente del } \\
\text { sistema social. } \\
\text { El aula se relaciona } \\
\text { con el sistenra } \\
\text { social en ocasiones } \\
\text { especificas, como } \\
\text { fiestas, conciertos, } \\
\text { austiciones, } \\
\text { presentariones de } \\
\text { alumnos, etc. } \\
\text { Mísica se estudia } \\
\text { de manera } \\
\text { adecuada fuera del } \\
\text { contexto escolar. } \\
\text { Asignatura 'Maria'. } \\
\text { con caräcter } \\
\text { ornamental. }\end{array}$ & $\begin{array}{c}\text { El aula interactia } \\
\text { ocasionalmente } \\
\text { con el sistema } \\
\text { social en concier- } \\
\text { tos, audiciones, etc. } \\
\text { para mostrar lo } \\
\text { aprendido. } \\
\text { Se aprende a } \\
\text { interacular con el } \\
\text { prithlico desde un } \\
\text { escenario. }\end{array}$ & $\begin{array}{l}\text { En ed aula se } \\
\text { reflejan } \\
\text { cuestiones } \\
\text { sociales } \\
\text { generales. } \\
\text { Se interactia con } \\
\text { un pablico para } \\
\text { mostrar } \\
\text { aprendizajes y } \\
\text { producciones } \\
\text { artisticas } \\
\text { arlersolar. }\end{array}$ \\
\hline
\end{tabular}




\title{
ANEXO C - Aula No 3 "MÚSICA - Percussão corporal: Mãos"
}

$14 / 4 / 2014$

BRASIL Acesso a informaçăo
Portal do Professor - MÚSiCA - Percussào corporal: Màos

Faltam 5 dias para a Copo

\begin{abstract}
VISUALIZAR AULA
\end{abstract}
MÚSICA - Percussāo corpor
Autorizo e Coautor(es)
Autor: RonRIGo RusSANo

ROD DE JANEIRO - R.I 0205009 ESCOLAMUNKCIPAL, ALENCASTRO GUIMARAFS

Coautca (es): Claudia Holuna Axovedo Nvarenga

\section{Estrutura Curricular}

\begin{tabular}{|c|c|c|}
\hline $\begin{array}{l}\text { MODALIDADE / NIVEL DE } \\
\text { ENSINO }\end{array}$ & $\begin{array}{l}\text { COMPONENTE } \\
\text { CURRICULAR }\end{array}$ & TEMA \\
\hline Ensino Médio & Antes & Musica: Contestualcarç̄o \\
\hline Ensino Mèdia & Artes & Misica: Estruturas sintaticas \\
\hline Ensino Midio & Avtes: & Misica: Canal \\
\hline $\begin{array}{l}\text { Educaşa de Jovens e Adultios - } 1 \text { " } \\
\text { cicle }\end{array}$ & $\begin{array}{l}\text { Eatudo da Sociedade e da } \\
\text { Natureza }\end{array}$ & Cultura a diversidade cultural \\
\hline $\begin{array}{l}\text { Educaçāo de Jovens e Adultus - } 2^{*} \\
\text { cido }\end{array}$ & Ales & Misica: desemolvmento da linguagem musical \\
\hline Ensino Fundamental Final & Arten & 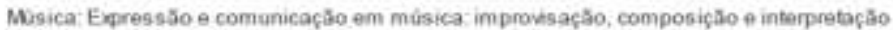 \\
\hline Ensino Módio & Avtes & Misica: Estruturas mortologicas \\
\hline Ensino Fundamental Final & Arten & $\begin{array}{l}\text { Misica: Apreciaçăo significativa em müsica: escuta, envolwmento e compreensão da } \\
\text { linguagem musical }\end{array}$ \\
\hline Ensino Fundamental Final & Artes & Misica Compreensibo da mùsica como perduto cultural e histonico \\
\hline
\end{tabular}

\section{Dados da Aula}

O que o alkino poder ấ aptender com esta aula

1. Explorar a conceito de percussilo corporal ublizando as palmas das măos (situaçồes cotidianas e preciedentes no repertório)

2. Expenimentar as varias possibilidades de produsäo sonora com màos

3. Criar una peça musical com a sonoridade das mâsos.

Duraçà̀o das atividades

T aula de 50 minutos

Conhecimentos previos trabalhados pelo professor com o aluno

O trabalho de percussilo corporal pode ser leito sem conhecimentos lormais pievios em Misica.

Estratègias en recursos da aula

Introduçăo

Caro professor, a coleçảo de aulas "MúskCA - petcussão corperal" vis-a a levar para a sala de aula um trabalho em que o corpo se transforma em instrumento musical Utilizando diferentes tipos de palmas, estalos, pleadas, e batidas bo tronco e na boca, é pos sivel consegair uma variedade de soens percussivos que pode servir para fazer musica. Ao ervolveir todo o corpo do executante nas peças musicais criachas - mäos, pés, boca, tronco, ette-podernos alcançar resultados mussicais servir para tazar misica. As.

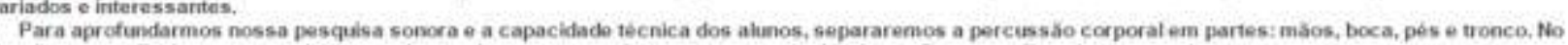
Brasil, o grupo Barbatuques se destaca pelo uso do corpo como instramento musical (veja em Recursos Complementares).

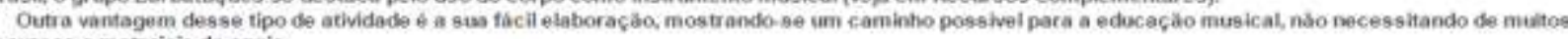
recursos e materiais de apoio.

Grupo Barbatuques 
$14: 4 / 2014$

Portal do Prolessor - MÚSICA - Percussáo corporal: Mãos

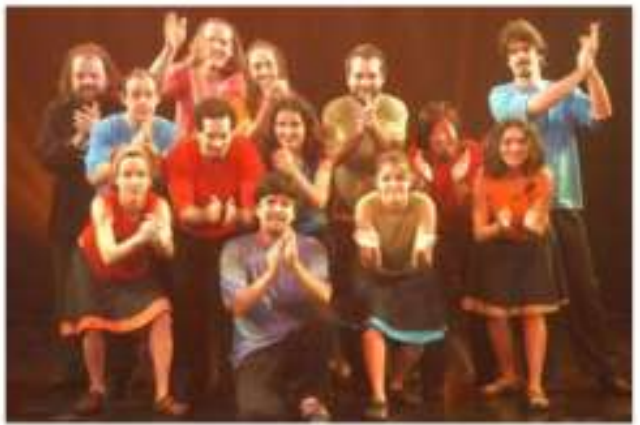

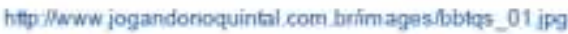

\section{Atividade 1 - Música e Paimas}

nicie a aula perguntando aos alunos sobre os muitos instrumentos que o homem criou ao longo de sua História para compor e fazer Misica. Converse brevemente

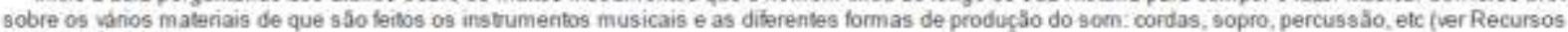
Complementares)

Entio, pergunte: "e se nảo possuimos nenhum instrumento musical, ainda assim é possivel facer Misica? E a voz humana? É instrumento musical? E quando

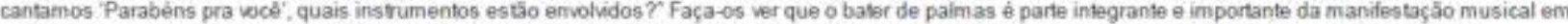
questio. Proponha que a mesma música seja cantada sem 6 acompanhamento das palmas para que sintam o estanhamento de ouvir a cança se sem elas.

Mostre peças musicais em que as mî̄os sejam usadas come instrumento. A seguir, sugerimos alguns enemplos, mas vocî pode utilizar outros que achar mais adequados

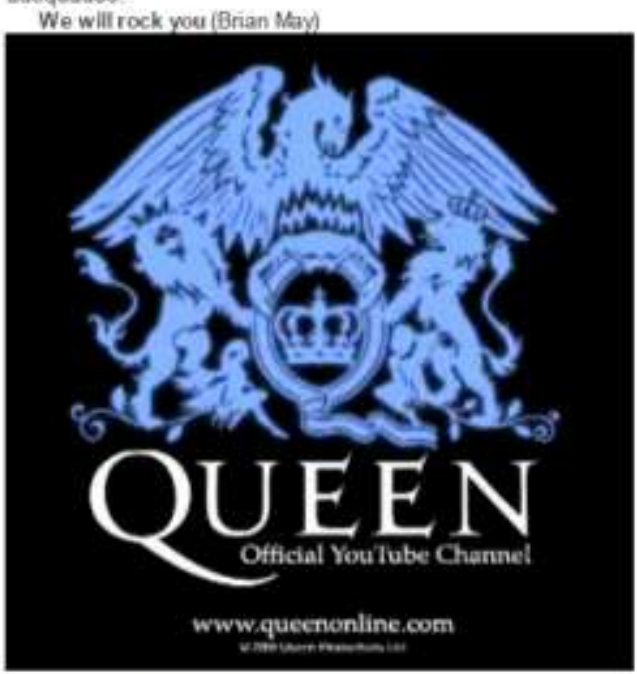

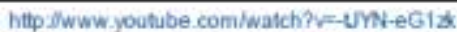

No Reply (LennonaMcCartney) - entre as momentas $104^{*}$ e $134^{*}$

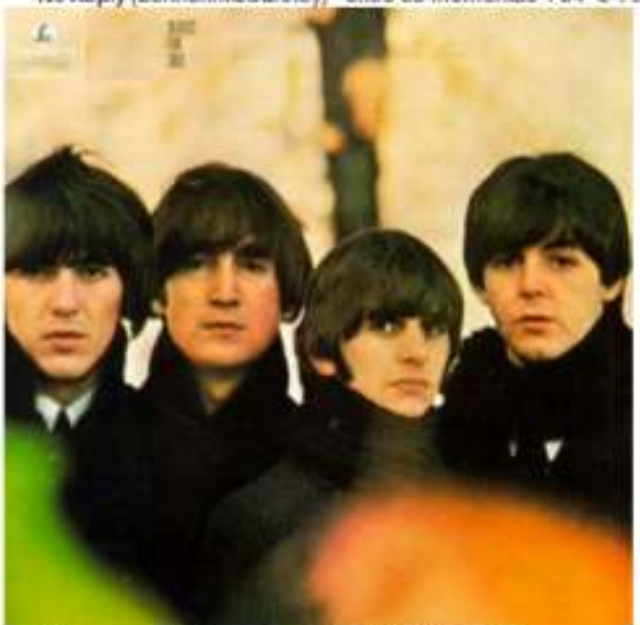

hitlp:lwww. youtube comiwatch?

Atividade 2- Experimentaçăo 


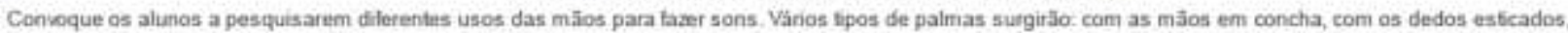
com as pontas dos dedos, etc. As malos podem ser friccionadas, dedos estalados etc. Enfím, budo o que a imaginaçă permitir. De alguns minulos para que façam a pesquisa e peça para $0 s$ ahunos mostrarem as diversas maneiras que encontraram. Ouais as diserenças entre elas? Ouais sonocidades com as mács soam com mais intensidade? Quais sâo mais agudas?

Aseguir, sugerimos alguns links como estimulo à pesquisa sonora.

Papo Body Drummer

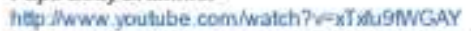

O autor deste video cria usando apenas as suas mbios. Serch quef os alunos conseguem identficar quantos timbres diferentes foram usados?

Coro 'Perpotuaum Jazzile' - Chuva

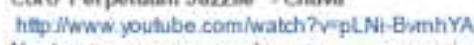

Nesta peça o coro, usando apenas o corpo, simula os sons de uma chuva com incrivel fidelidade. A peça possui diserentes momentos: chuvesco, chuva forte e trovétes. Como essas sonotidades foram alcançadas? Ouais as diferenças tentre os sons nos dferentes momentos? Tena o mesmo efeito caso fosse feita por apenas uma pessoa? Observe que a grande quantdade de pessoas realicando as paimas, toma a sonoridade mais prónma do etaito de chuva

Depois de pesquis ar as diferentes sonoridades obtidas com as milos, experimente refaxer o caminho do video apresentado Faça uma listagem dos tpos de paimas na ordem em que aparecem. Treine com a turma buscando a qualidade do som Escolha um regente (aluno) e oniente os alunos na reconstructo da sononidade da tempestade assistida no video.

\section{Atividade 3 - Roda de Improviso}

Faça um exercicio de aquecimento e de improviso

1. Forme uma roda com os alunos. Cada aluno deverá apresentar seu improviso com paimas. Ontono será five mias cada aluno, em seu improvso, deverà transformar um timbre de palma escolhido om outro dí́serente e, a seguir, passar para o colega. Peça que pesquisem a passagem de uma sonoridade para outra Em que momento um som de palma muda de categoria fimbristca?

2.0 próxmo colega a improvsar deverà começar com o mesmo timbre em que o aluno anterior terminou. Peça aos alunos para terem o cuidado com a qualidade do som obtido. Siga ate que sodos tenham feito seus improvisos.

Dices

Explique que o trabalho visa a sxplorar os fimbres conseguidos com as m5̄os, entso asfimule-0s a mudar de abordagem, utlicando diderentes sonocidactes com as mấcs

Estabeleça daramente a regra quando um aluno passar a vez, o próvimo devera iniciar seu trabalho usando o mesmo fimbre de mão com que seu antecessor berminou sua improvis açäo.

\section{Atividade 4 - Composiçăo}

Então, divida a turma em grupos de ate quatro alunos e peça para os alunos comporem, usando as mãos como instrumento, um fragmento musical que se repiti e sirva de base percussiva para o grupo. Este fragmento funcionará como um elemento estruturador da composiçăo da seguinte manesa

1. Enquanto os alunos realizam o framento criado, um aluno improvisara fivemente. Peça aos alunos que fazens a base percussiva com 35 milos, que hoquem suavemente para que o improveso seja ouvido.

2 Oiando o impeovisador esher satis feito, voltara a realizar a base percussiva junto com o grupo, passando a vez para o prónmo colega

Ao final, todos deverão apresentar suas pequenas criaçöes musicais sobre as bases percusskas.

Recursos Complementares

Sobre percassăo corpot al (Barbatuques) - hitlp / / www yputube com/watch? W R gXYPZgcrk

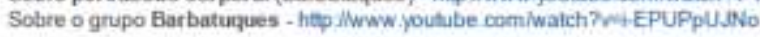

Sobre instrumentos musicais, veja a aula

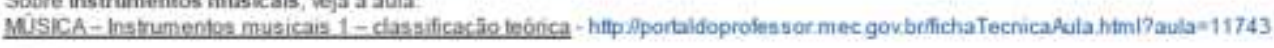

Avaliaçăo

Considere na avaliação

1. a qualidade, a variedade e a realizaçīio sonora do inventiría de sons listados pelos alunos.

2. a participaçīio na roda de improviso e nas afividades de criaçẫo

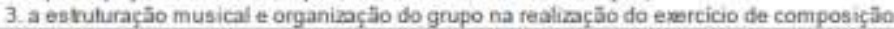




\section{ANEXO D - Aula N7, "Uma orquestra diferente"}

$14 / 4 / 2014$

BRASIL

Acesso a informaçăo
Portal do Professor - Uma orquestra diferente

Faltam 5 dias para a Copa \begin{tabular}{l|l|l|l|} 
Participe & Serviços & Legisiaçăo & Canais
\end{tabular}

\begin{tabular}{|c|c|c|}
\hline \multicolumn{3}{|l|}{ MSUALIZAR AULA } \\
\hline \multicolumn{3}{|l|}{ Uma orquestra diferente } \\
\hline \multicolumn{3}{|l|}{$\begin{array}{l}19,06 / 2009 \\
\text { Autor e Coautor(es) }\end{array}$} \\
\hline \multicolumn{3}{|c|}{ Autor: Jufiana Gomes de Souza Dias } \\
\hline \multicolumn{3}{|c|}{ CURITIBA - PR SECRETARIAESTADUNL DE EDUCACAO } \\
\hline \multicolumn{3}{|l|}{ Coautor(es): Eajquabl Manta } \\
\hline \multicolumn{3}{|l|}{ Estrutura Curricular } \\
\hline $\begin{array}{l}\text { MODALIDADE } / \text { NIVEL DE } \\
\text { ENSINO }\end{array}$ & $\begin{array}{l}\text { COMPONENTE } \\
\text { CURRICULAR }\end{array}$ & TEMA \\
\hline Ensino Fundamertal Final & Ntes & 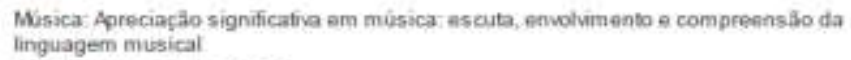 \\
\hline Ensino Medio & Fisica & Som, imagem e informaçă̄o \\
\hline Ensino Madio & Antes & Musica. Estruturas morlologicas \\
\hline Ensino Mbdio & Antos & Misica: Canal \\
\hline Ensino Médio & Ates & Misica Estruturas sintaticas \\
\hline Ensino Fundamental Final & Artas & 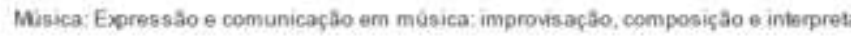 \\
\hline
\end{tabular}

\section{Dados da Aula}

0 que o aluno poderá aprender com esta aula

Criar sons, desenvolver o ritmo e compor melodias a partir de instrumentos missicais criados com material reciclado.

Duraçăo das atividades

1 a. 2 ailas de 50 minutos cada, dependendo do rendimento dos alunos

Conbecimentos prévios trabalhados pelo professor com o aluno

Nāo sẳo necessánicias conheciméntos próvios

Estratégins e recursos da aula

Aula 01: O professor deverà questonar a turma sobre $\mathrm{D}$ que é uma orques tra: qual a diforença ente uma banda e uma orquastra, quais os inatrumentos compóem uma onquestra

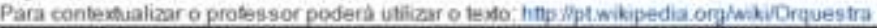

A orquestras completas dà-se o nome de orquestas sinfonicas ou orquestras filarmánicas embora estes pirefixos näo especifiquem nenhuma diferença no que foca à

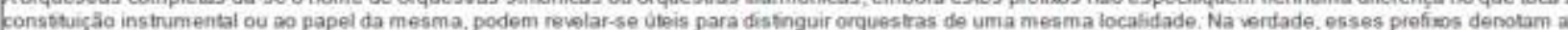

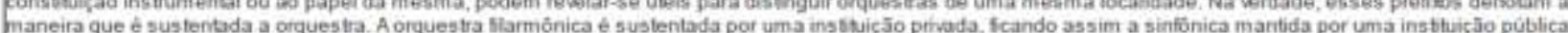
Uma orquestra lera, tipicamente, mais de oilenta músicos, em aiguns casos mais de cem, embora em actuaç̧̃o esse número seja ajustado em funçíio da obra

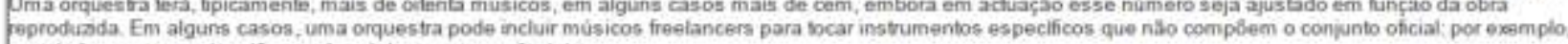
hem todas as orquestras têm um harpista ou um saxolonista.

Uma orquestra sinfönica diapōe cinco classes de instrumentos.

- as cordas (volinos, violas, voloncelos, contrabaixos, harpas)

- as madeiras (flautas, flautins, oboes, come-inglés, clarinetes, ciannete baioo, fagotes, contratagotes)

- os metais (trompeles, trombones, trompas, tubass)

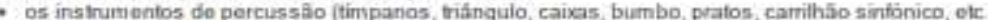

- os instrumentos de leclas (piano, cravo, órgäo)

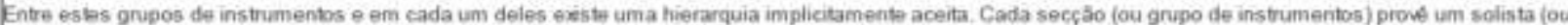
prindpal) que será o protagonista dos solos e da liderança do grupo. Os volinos șo divididos em dois grupos. primeiros volinos e segundos viofinos - o que pressupöe dous principais. Oprincipal dos primeiros violinos é designado come chefe nibo so de toda a seccto de cordas mas de toda a orquestra subordinado unicamente ao maestro, esse violinista e denominado spalla. Nos metais, o primeiro trombonista é olider, enquanto que nas madeiras ssse papel cabe ao primeiro obolsta

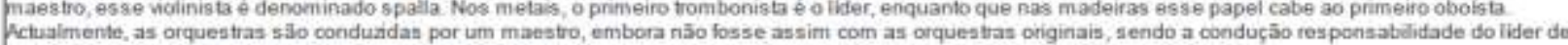
Actualmente, as orquestras silo conduadas por um maestro, embora nẫo fosse assim corn as orques tras originais, sendo a contur

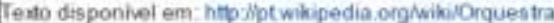


Atençầ professor! Se possivel apresento para os alunos alguns instrumentos musicais profissionais, para que eles eninndam seu funcionamento e sua imiportíncia dentro de uma orques tra. Aoresente umbém algumas músicas compostas por Orquestras.

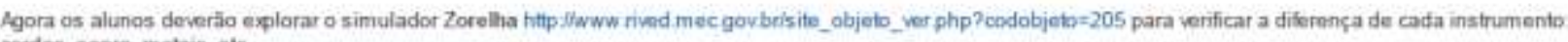
cordas, sopro, metais, etc

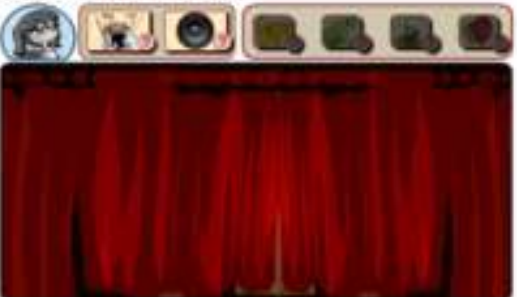

Agora os alunos irilo conhecer o grupo Blue Man que ufiliza materiais altomativos como instrumentos musicais Nesse primeiro video o grupo ubiliza canos de PVC para criar sons

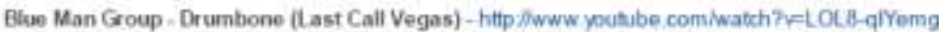

Atençào professoft Questone os alunos sobre a intensidade das batidas, o ribmo, a reverberaçăo do som no cano, efc. É interessante que o prolessor de fisica auxilie o professor do artes nossas questb̄es

No video Blue man group shadow drumming pve o professsor deverá insfigar os alunos em relaçăo ao timo: quanto mais acelerado mais intensa as cores, quanto mais

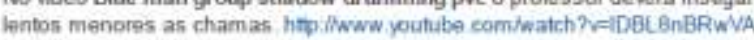

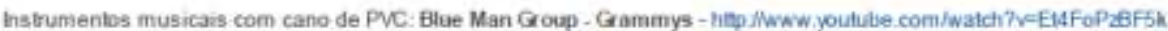


Para essa afividade indicamos o àudio: Gravidez na adolesceoncia que vai indicar coma produar instrumentos musicais a partir do matoriais reciclados

odolescoincia

Após o dudio b́ hora dos alunces produarom seus instrumentos

Asençào professos! Auxilie os alunos na construçăa dos instrumentos musicais, escolha dos materiais, etc. Griente a turma para compor uma música a partir dos instrumentos. Em Recursos Complementares indicamos um sitn com exemplos de instrumentos criados a partir de sucatas

\section{Recursos Educacionais \\ NOME \\ TIPO \\ Gravidezna adolescéncia Ảudio}

Recursos Complementares

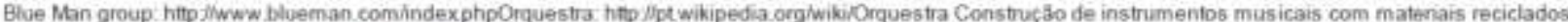
hitlp :licybolemever blogspot com/200801 hinstrumentos-musicais-com-sucats htmi

Avaliaçào

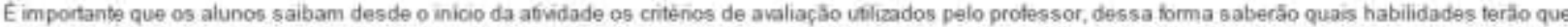
desenvolver com a atividade. Nesse caso sugerimos que o peofessot avalie a parficipaçăo do aluno nas discussōes, o interesse dele pela temática, a compreens äo do

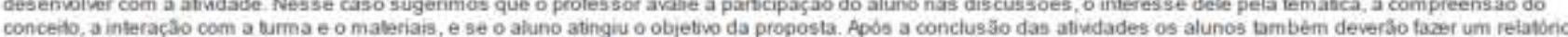

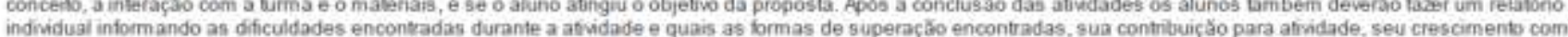
rełaçẫo aso contecudo, elc 


\section{ANEXO E - Aula N¹9, "Música - criação de canção: ritmo e gênero"}

$14 / 4 / 2014$ BRASIL Acesso à informaçāo
Portal do Professor - Música - criaçào de cançác ritmo e género

Faltam 59 diaspara a cope \begin{tabular}{l|l|l|} 
Participe & Serviços & Legislaçāo
\end{tabular}

Canais

\section{VSUALIZAR AULA \\ Música - criaçāo de canção: ritmo e gênero \\ 01082010 \\ Autor e Coautor(es)}

Autor: Leonardo Stohano Misquio

RMO DE JWIEIRO - RJ COL. DE NPLIC DAUNIVFED DO FOO DE JANEIRO

Coautor(es): Claudia Helena Asowedo Aluarenga

\section{Estrutura Curricular}

\begin{tabular}{|c|c|}
\hline $\begin{array}{l}\text { MODALIDADE / NIVEL DE } \\
\text { ENSINO }\end{array}$ & $\begin{array}{l}\text { COMPONENTE } \\
\text { CURRICULAR }\end{array}$ \\
\hline Ensino Fundamental Final & Antes \\
\hline Ensino Fundamental Final & Aetes \\
\hline $\begin{array}{l}\text { Educapialo de Javens e Aduilias - } 1^{\prime \prime} \\
\text { cido }\end{array}$ & $\begin{array}{l}\text { Estudo da Sociedade e da } \\
\text { Naturega }\end{array}$ \\
\hline Ensino Fundamental Final & Actes \\
\hline Erssino Mbidio & Avtes \\
\hline Ensino Mertio & Ates \\
\hline Ensino Mbodio & Actes \\
\hline $\begin{array}{l}\text { Educasalo de Jovens e Aduhos }-2^{\circ} \\
\text { dido }\end{array}$ & Antes \\
\hline Ensino $\mathrm{M}$ & Ates \\
\hline
\end{tabular}

\section{TEMA}

Masica Compreensẫ da mùsica como produdo cuitural e histárica

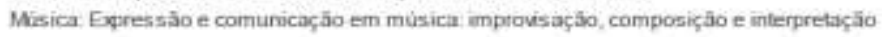

Culara e diversidade cultural

Musica Apreciacto significativa em mésica escuta, envolumerito e compreens ăo da ingungem musical

Misica Canal

Misica Contcrevatimatas

Misica Estruturas morfolögicas

Misica desenvohimento da linguagem musical

Mosica Estrunuriss sintapcas

\section{Dados da Aula}

O que o aluno podera aprender com esta aula

- Relacionar os conceitos de nímo e de género musical

- Analisar estio e forma de uma canc.jo popular

- Trans formar o malerial musical oriqinal criando uma nova composiçẩ

Duraçăo das atividades

1 auta de 50 minutos

Conhecimentos previon trabalhados pelo protessor com o aluno

- Conhecimento musical informal

Estratoglas e recursos da auta

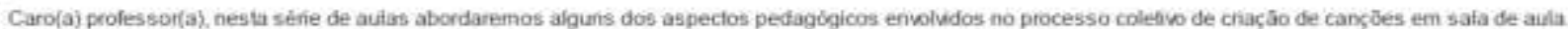

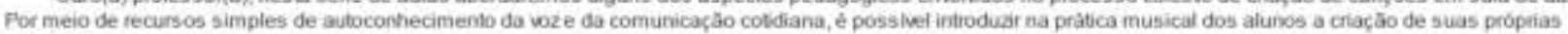
cançöes

Da mesma maneira como a cnanca se permite nscar o papel em suas primeiras 'garatujas' e desenhos, acneditamos ser poss hel incentivar jovens e cranças a produatr e a organizar seus pribrios sons cantados. Muitas veres a cotrança poe um 'resultado' pratico, 'bonito' e condizente com os padrüess identficados nos meios de

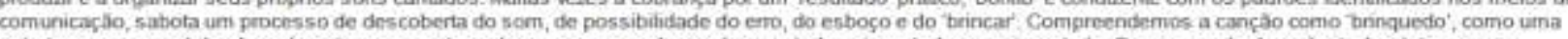
estrubura com a qual desde cedo estamos acostumados, mas que pode ser desmontada, reirventada, experimentada. Opercurso de descoberta 4 salutar para o desenvolumento cognitive expressive

Conceitualmente, propomos uma perspectiva de misica contemporânea na abordagem da cançäo popular. Histcricamente, a entrada dos composidores contemporáneos, como Schafer e Kcollineutter, no campo da educaçào musical, contribuiu para uma ampliaçäo do conceito de música ao considerar que qualquer som pode ser orgarizado com intenconoalidade musical. No entanto, no Brasil, esta abertura de peesamento, em gerat, nâo taz parte do coticiano mursical do püblico nảo

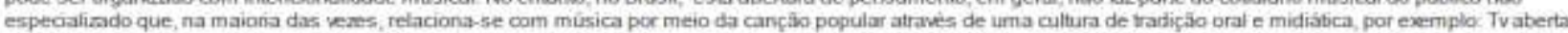

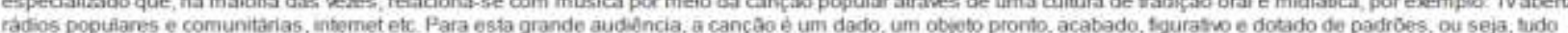

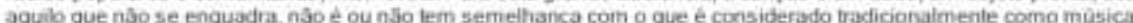

Esta série de aulas tem por finalidade contribuir para uma compreens-iso critica sobie as maneiris como a criança e ojovem de hoje se felacionam com música. Aerecitamos que com isso podemos estimular uma relaçăo com música para além da repeoduçajo de um repertónio ja conhecido. Com este intuilo, suagerimos que seja

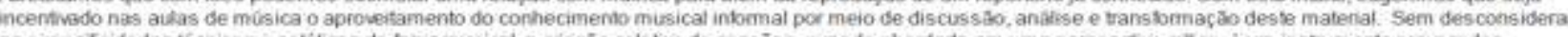

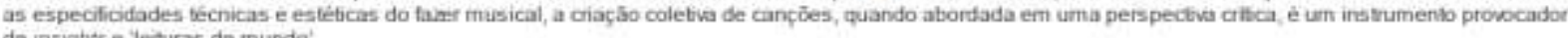
de insughtis e leituras de mundo'

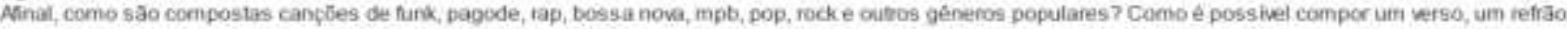

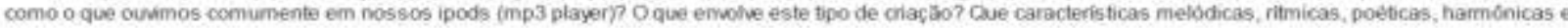


interpretativas, encontramos em cada estilo? Oualquer pessoa pode compor uma canção ou é algo destinado aperias a alguns poucos talenlos iluminados? Oual o sentido de compor uma cançăo hoje? É relevante? O que pode expressur? É possivel compor uma cançăo mesmo com pouco conhecimento tecrico e recursos limitados?

Nesta séfie de aulas propomos problemalizar aspectos como estes e desafiar o professor a levantar outros tỏpicos para discussăo com seus aíunos . Ao esboçar respostars através de uma atiundade prática de citação de cançốes, sugerimos aos educadores que resiflam sobre a necessidade constante de busca por uma açāo musical significativa construida junto aos secis alunos.

Para uma pesquisa inicial sobre cançäo e sua hiskiria, vide links 1,2 e 3 em Recursos Complementares

- Cançào

- Oseculo da cança

- História Social da Música Popular Brasileira

Sobre prafcas de craçăo em mùsica, wde links 4 e 5 em Recursos Complementares

- Müsica na Etucaçăo Infantil

- Koelireutter Educador

Sobre ritmo e getnero musical, vide links 6,7 e 8 em Recursos Corsplementares.

- Ritmo

- Cenero musical

- Lista de gèneros musicais

\section{Atividade 1 - Ritmos e gèneros}

Protessor(a), inicie uma discuss ão a respento de estlos musicais que os alunos conhecem e elabore uma lista com as suas sugestöes Pergunte sobre caracterisocas que diferenciam um tipo de música de cutro. Apgumas poss heis instrumentaçăo, texto, funçabo, estruhura, contextualização, etc. E o ntmo? O tipo de acompanhamento rilmico de uma música tamberm caraciefiza uma diferença de estio?

Aviresente acis aluncis os sonuintes ejaminlos

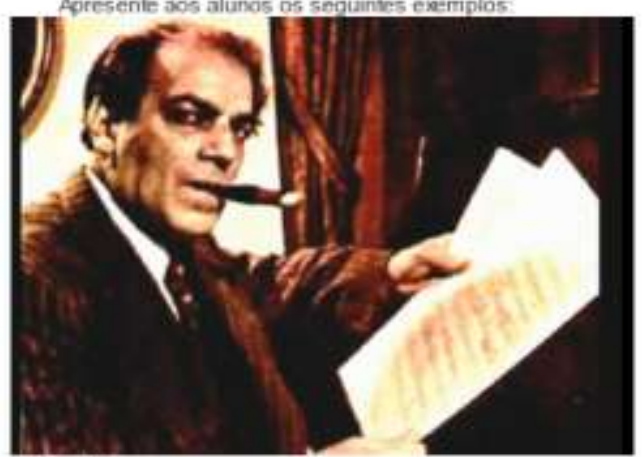

Vilia-Lobos

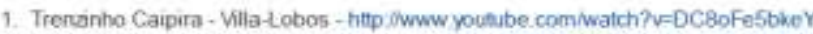

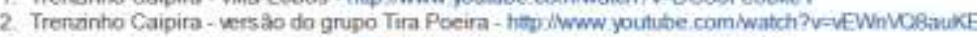

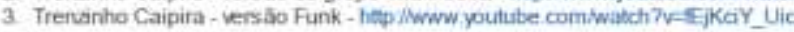

Na versäo original do Trenaniho Capira de Villa Lobos, o composalor constroi a natrative sonora inspirado nas caracteristicas do movirnento de uma locomotrua. Os efeitos são obsdos atravess de diversos recursos expressivos com instrumentos da orquestra e se distinguem tanto pelo astecto fimbrís fico, quanto pela titmica. Por exemplo sopros que alternam entre um papel inelodico e etertos de apibo do trem na estaçäo; percuss des que simulam o impacto diss rodas gobre os trilhos e ao mesmo tempo reţroduarem andamentos variados de aceleraçio e desaceleraçáo do trem, etr.

A versāo do grupo Tira Poeira apresenta uma sêne de possibilidades de efeilos com instrumenitos tipiccos de um regianal de choro; pandeiro, volöes, bandolim, alérn do sax soprano (mais contemporáneo). De imediato, percebemos que o arranịo mantem um dos aspectos principais da obra. a simulaçăo do movimento do trem. Para obter este etevo, os músicos subventem, em alguns momentos, a forma de tocar os instrumentos. Por exemplo, raspando, abatando e fasgueando as cordas dos volóes e do bandolim, batucando no tampo, etc. O pandeiro assume as funçbes de conduar as variaçöes de andamento $e$ de reforçar a sononidade dos trilhos ${ }^{-} e$, para tanto, exgem bastante vertunsismo do instrumentsta Jì o sax soprano, derentia a linha meiodica principal, berm como os etritos de apito de chegada e partida do trem Uma

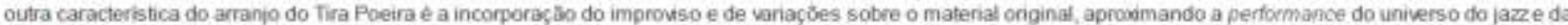
experimentacto.

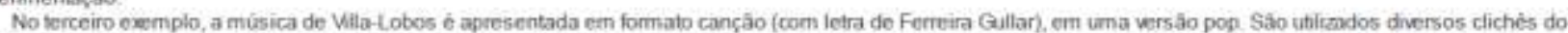
estilo batida eletónica constante; vbratos na voz, timbre e sotaque vocal tipicos de cantoras da música pop americana, repebic bes de leta, etc. Eleitos de sirntretizador

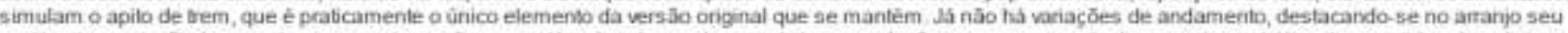

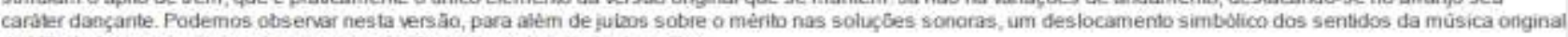
de Vila tobos, por se tratar de uma associaçio um tanto inusitada de estilos

E muib interessante disciftir com os alunos como estas versóes podern apresentar eleitos ao mesmo tempo diversos, do pointo de vista semäntico, e parecidos, meame com insthumentaç̋̄es muino distintas. Em ambas as versōes, tata se do imagináno de um trem em movimento representado atraves de sons, seja em uma perspectiva reatista ou como mero pretexto para uma cotaçăo conceitusi

Proponha um novo exercicio de audiçäo, agora com estes outros links abaixo. 


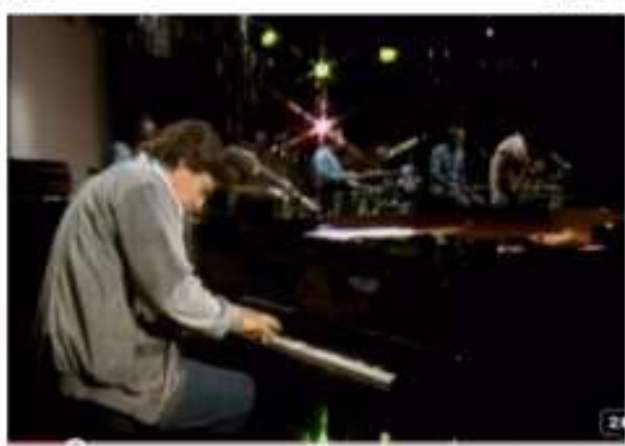

Tom Jobim

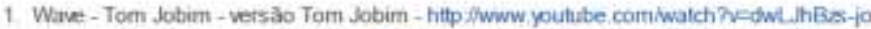

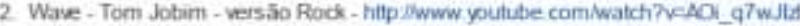

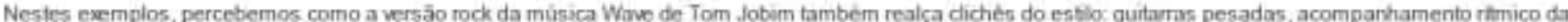

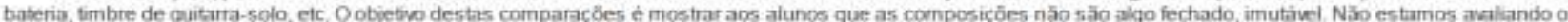
grau de criativdode da versăo rock, mas sim, observando este material como evercioo, como pesquisa por maneiras diversas de transforntar elemtentos musicais $e$ principalmente, criar novas composiçoes.

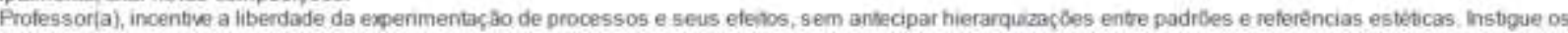
alinos a pesquisarem outras combinaçes possheis ou vers des diferentes de músicas que jâ conhecem. Aos poucos, as descobentas e constantes exercicios de comparaçб̄es $e$ análises formiam a base para una leitura critica e uma audicâo mais aguçada

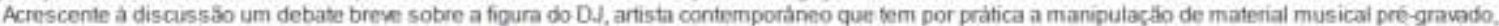
transformando muitas vexos a 'batida' do acompanhamento. O.J é um müsico? Oque ele fazé música?

\section{Atividade 2 - Análise da forma}

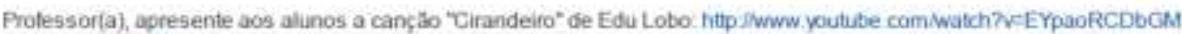

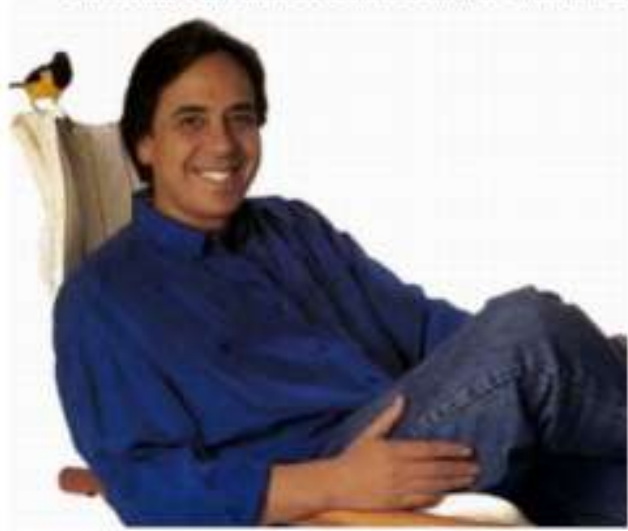

Fidu tobo

Sobre ciranda, wide links 9 e 10 ein Renursos Complementare

Distribua a leta da mísica e cante com os alunos

Cirandeiro

Geirandeiro

Ócirandeiro, $\alpha$

Apedra de teu anet

Britha mais do que o sol

Ocirandeiro.

Ó cirandeiro ó

A pedra do teu ane:

Brilha mais do que a sol

A cranda de estrelas

Caminhando pelo céu

Eoluar da fua cheia

Eo farol de Santarem

Näo o lua nom estreła

Esaudade dareando

Nos olhinhos de meu ber

É saudade dareando

Nos olhinhos de meu bem

ó cirandeiro, ó cirandeiro, ò

Apedra do teu anel
Britha mais do que o sol

$O$ cirandeiro.

Ó cirandeiro, do

A pedra do bu ane

Erilha mais do que o sol

A ciranda de sereno

Vsitando a madrugada

Oespanto achei dormindo 
Nos sonhos da namorada

Oue serena dorme e sonha

Carregada pelo vento

Num andor de nuvern clara

Carregada pelo vento

Nurn andor de nuvem clara

Ocirandeiro

Ocirandeiro, 0

A pedra do teu anel

Brilha mats do que o sol

Ó cirandeiro,

Ocirandeiro, 0

A pedra do teu anei

Bnilha mais do que o sol

Sabo sete estrelas correndo

Sete juaras a jurar

Trés Manas. Trés Manias

Se cuidem de bom cuidar

No amor c o juramento

Que a estrela Dalva chora

De nos sele acreditar

Oue a estrela D'alve chora

De nos sele acreditar

Ó cirandeiro,

ó cirandeiro, o

Apedra do teu anel

Brilha mais do que o sol

Ó cirandeiro.

0 cirandeiro, $o$

A pedra do tou anel

Aritha mais do que o sol

Depois de cantar algumas veases, analise com os alunos a forma da música. Esta apresenta a seguinte sequéncia. Refrào, Parto A Refráa, Parte B, Refräo, Parte C,

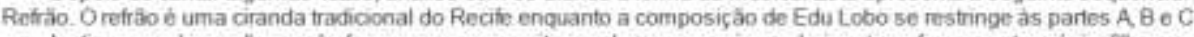

Insfigue os alunos: "se vocés fossem os compositores, de que maneira poderiam transformar esta música?".

Debata as ideias que surgirem e estabeleça uma lista de possibilidades imaginadas pelos alunos de modificaça do material musical. Vale destacar, que a própria Versão inicial é o tesullado de transformaçôes que a mùsica sofre na prática popular ao longo de muitos anos. Esłe aspecto em constanie movemento se relaciona com a noção de que a cultura nio ê algo estavel ou imóvel, mas uma complexdade de elementos em continuo processo de mudanças

\section{Atividade 3 - Criaçao musical - texto}

Proponta aos alunos que transformem a mùsica do Cirandeito, mantendo apenias sua forma e palivas-chave da letra Outros aspectos como meiodia, ritmica, acompanhamento, frases do texto e estilo, deveräo ser modificados pelos alunos. Nivo é necessano se ater a quaisquer caracteristicas da versaio inicial. Cons trua uan banco com as palavass-chave, por exempio- cirandeiro, pedra, anel, sol, sereno, madrugada, namorada, sonhos etc.

Dice

Para a construçăo de um banco de palašas, veja a Atividade 2 da auta

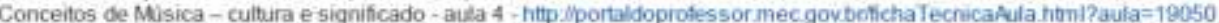

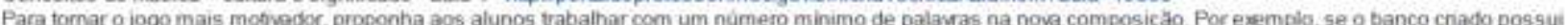
24 palasas, peça que a composiçăo dos alunos mantenha no minimo 12 destas palawas. Outras variantes podem ser sugendass de acordo com a criativiade do professor e da sua turma

Obs: Esteja disponivel para ouvir as ideias dos alunos Muitas veass acescentam aspectos exremamente inowadores, polencialuandfo o sentido da ativdade e abrindo novos Giminhos. Busque sempre incorporar as sugestôes do grupo e as que năo forem poss heis de serem realizadas naquele mornento, anote e resgate em uma aula futura

\section{Atividade 4 - Criaçào musical - melodia e forma / Performance}

A partir das palavas, instigue os alunos a criarem frases e melodias para uma nova composiçầo. E como criar uma melodia? Sugestio

1. Fale as paliavas ou tases com uma determinada enbnaçăo. Experimente variaç̄es

2 Cante uma das palavas e a partir dos primeiros sons surgidos tente amplio las

3. Crie ritmos com as palavas $e$, em seguida, expenmente acrescentar alturas.

E importante que os alunos sintam-se à wontade para experimentar os sons, sem preocugaçăo com um som que seja certo ou eirado, dentro ou fora dos padróes. A expenéncia de cantar a ideia melódica proposta por um aluno com bơa a turma pode afivar a criatividade e encorajaj-lo:

Dé tempo suficiente para que os alunos organizem-se em grupos de 4 a fi pessoas, elaborem, ensaiem a composição e apresentem para a tuma.

1. Permita que acrescentem termos conectivos e cutas palavar que se facam necessatrias nara dialogar com as palavas do banco

2 Desafie os alunos a manterem a mesma korma da música onginal: Retriko, Parte A Reträo, Parte B, Refrìo, Parte C, Refribo

\section{Recursos Complementares}

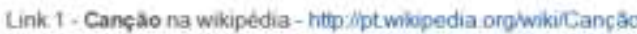

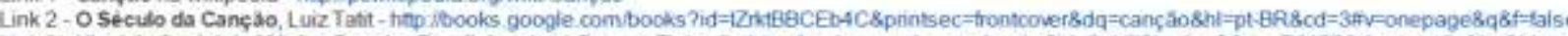

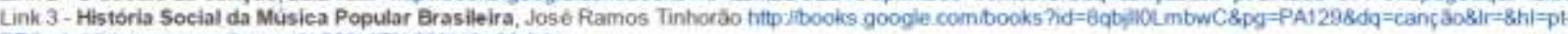

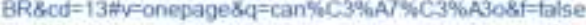

Link 4 - Mùsica na Educaçāo Infantil. Teca Alencar de Brito hitlp jbocks google comitbooks?

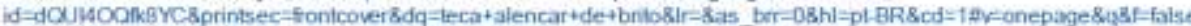

Link 5 - Koellirautter Educador. Teca Aencar de Brito hetp ibooks, google combooks?

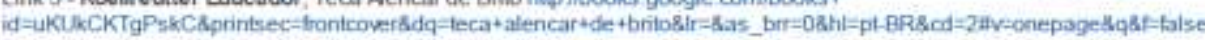

Link B - Ritmo na wikipédia - http lipt wikipedia arg/wikifiamo

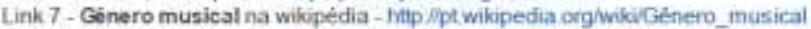

Link 8- Lista de getneros musicais na mikpedia - htlp Mptwikipedia ovghnkolista de gênercs musicais

Link 9-Ciranda - hitp ildancas brasileiras whispaces.com/Ciranda

Link 10 - Mursica - Cantando e dançando a ciranda - aulas 1 a 6 
$14 / 4 / 2014$

Porta do Professor - Música - criaçắo de cançăo ritmo e género

hittp Ilportaldoprofessor mec govibeficha TechicaAula himl?aula=13599

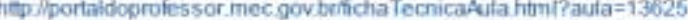

intpllportaldoprofessor mec gov berficha TecnicaAula html? aula=13671

hile Aportaidoprofessar mec gov beficha TecnicaAula himl?aula $=13872$

hesep flportaldoprofessor mec gov beflichaTecnicaAufa himl? asila=14897

hitg: /portaldoprolessor mec gov beflicha TecnicaAufa fitml?aula=14900

\section{Avallaçào}

Ao final da atvidade, obsene se os alunos atingiram os objetros propostos. Analie:

1. Relacionaram o conceito de nitmo ao de genero musical?

2. Aprenderam a cantar a música 'Cirandeiro', analisando seu estilo e forma?

3. Conseguiram transfommar o material musical onginal criando uma nova composiçào?

4. Elaboraram cançbes com intençào de manter a boma e as palavas-chave?

5. Conseguiram discutir em coniunto a composichto e tomar decisóes em anpo?

6. Motivaram-se com a possibilidade de modificar músicas que conhecem? 